UNIVERSIDADE DE SÃO PAULO

FACULDADE DE EDUCAÇÃO

ALEX BELLUCCO DO CARMO

Argumentação matemática em aulas investigativas de física

São Paulo

2015 


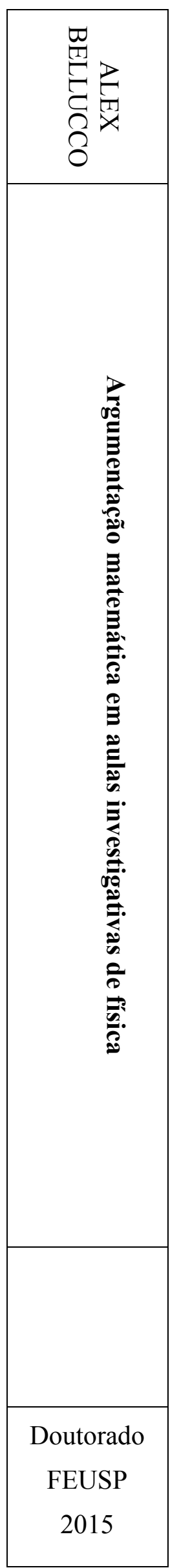


Argumentação matemática em aulas investigativas de física

Tese apresentada ao Programa de PósGraduação da Faculdade de Educação da Universidade de São Paulo para obtenção do título de Doutor em Educação

Área de Concentração: Ensino de Ciências e Matemática

Orientadora: Profa. Dra. Anna Maria Pessoa de Carvalho

São Paulo 
Autorizo a reprodução e divulgação total ou parcial deste trabalho, por qualquer meio convencional ou eletrônico, para fins de estudo e pesquisa, desde que citada a fonte.

Catalogação na Publicação

Serviço de Biblioteca e Documentação

Faculdade de Educação da Universidade de São Paulo

375.3 Bellucco, Alex

B449a Argumentação matemática em aulas investigativas de física / Alex Bellucco do Carmo; orientação Anna Maria Pessoa de Carvalho. São Paulo: s.n., 2015.

$251 \mathrm{p}$.

Tese (Doutorado - Programa de Pós-Graduação em Educação. Área de Concentração : Ensino de Ciências e Matemática) -- Faculdade de Educação da Universidade de São Paulo).

1. Argumentação 2. Matemática 3. Física 4. Linguagem 5. Ensino Investigação I. Carvalho, Anna Maria Pessoa de, orient. 
BELLUCCO, A. Argumentação matemática em aulas investigativas de física. Tese apresentada à Faculdade de Educação da Universidade de São Paulo para obtenção do título de Doutor em Educação.

Área de Concentração: Ensino de Ciências e Matemática.

Aprovado em:

Banca Examinadora

Prof. Dr. Instituição:

Julgamento: Assinatura:

Prof. Dr. Instituição:

Julgamento: Assinatura:

Prof. Dr. Instituição:

Julgamento: Assinatura:

Prof. Dr. Instituição:

Julgamento: Assinatura:

Prof. Dr. Instituição:

Julgamento: Assinatura: 
À minha esposa Vitória por "olhar juntos na mesma direção" sempre. 


\section{AGRADECIMENTOS}

Por mais que uma pessoa possa aparentar ser independente, as relações sociais são essenciais para o seu desenvolvimento pleno. Dessa forma, reconheço que seria impossível a realização deste trabalho sem o apoio, a amizade, o carinho e, principalmente, os 'puxões de orelha' de vários amigos e amigas que eu tenho muito prazer em agradecer.

À minha orientadora Anna Maria, que muito bem problematizou as várias etapas desta pesquisa e pela ajuda na estruturação inicial dos conhecimentos sobre argumentação ao longo da disciplina da pós-graduação. E também por toda paciência, amizade e dedicação ao longo desses anos que estou sob sua orientação no LaPEF.

Aos professores Maurício Pietrocola, Elio Ricardo e Luiz Carlos de Menezes, que tanto contribuíram para a minha formação complementar nas disciplinas da pós-graduação.

Aos professores Orlando Gomes de Aguiar Júnior e Lúcia Helena Sasseron que forneceram valiosas sugestões a este trabalho durante o exame de qualificação.

Sem dúvida nenhuma esta pesquisa não poderia ser realizada sem a imensa colaboração do professor Jonas, que é um profissional dedicado e muito competente. Obrigado professor! Agradeço também aos teus alunos que tanto me ensinaram nesse processo.

Não poderia deixar de lembrar dos meus amigos "lapefianos" que compartilharam muitos momentos de trabalho árduo e de alegria ao longo desse anos, que mesmo à distância sempre colaboram com minhas reflexões sobre a pesquisa e sempre me deram força. Um agradecimento especial para Rogério, Renata, Jackson, Josias, Tadeu, Tatiana, Élcio, Lucélia, Andrey, Nicolli, Arthur e Amanda.

Aos amigos Ricardo, Jorge e Pedro pelas ricas discussões sobre a relação entre a matemática e a física na nossa humilde versão da "Akademie Olympia".

Ao meu avô Rubens que despertou em mim esse universo do "faça você mesmo" e aos colegas "handmakers" do site "Handmades" que me ajudaram a compreender melhor o mundo da eletrônica. Um agradecimento especial ao Alex Frias e ao Guilherme (Gfr), que me ajudaram a entender o funcionamento do microfone PZM e seu préamplificador, equipamentos fundamentais para o sucesso da pesquisa.

Aos amigos da CENP (atual CGEB), em especial Renata, João F., João B., Fábio, Juliana, Natalina, Ari, Jeronimo, Beth, Kida e Anderson por me aceitarem por um curto e rico período de aprendizagem. Muito obrigado pelo apoio e pelas boas risadas!

Aos alunos e professores da E.E. Prof. Augusto Meirelles Reis Filho, local onde iniciei a construção e implementação das atividades de ensino apresentadas neste trabalho. Um agradecimento especial aos professores Carlos, Neli, Paulo, Josefa, Said, Heber, Ider, Donizette, Denise, Paula, Alessandra, Magda, Adilson, Abner e tantos outros que me ajudaram a compreender melhor o que é o sistema de ensino e o que é o processo de ensino e aprendizagem. 
Minha formação complementar também se deu no trabalho do Redefor, agradeço a todos os colegas, principalmente o professor Marcelo Giordan.

Um imenso obrigado ao professor José que me ensinou muito sobre disciplina e sobre encarar de uma forma positiva os desafios que se apresentam na vida.

Aos colegas do departamento de física da UDESC que me receberam muito bem nessa nova fase da vida. Agradeço ao amigo Luiz Clement pelas discussões sobre ensino por investigação e à professora Cíntia pelo apoio. E também, à minha amiga Ivani que me recebeu na UDESC e que confiou no meu trabalho, além de me ensinar muito sobre a profissão docente no ensino superior.

Ao amigo Carlos, o "Zorak", pelas discussões sobre educação e ensino de física, pelos momentos de descontração e pelo incentivo ao meu retorno ao futebol, mesmo eu sendo um "perna de pau".

Aos alunos do curso de licenciatura em física da UDESC pelos questionamentos que me auxiliaram a refletir sobre a pesquisa.

Não poderia deixar de agradecer aos meus grandes amigos João Luiz Braghetta, meu pai musical e Jorge Pereira, que muito me ensinaram sobre música e muito contribuíram para a estruturação de minhas ideias por meio da aprendizagem propiciada pelo nosso grupo de violões. Agradeço também aos demais amigos de "tocatas" e "circulações", principalmente Alexandre, Gabriel, e Ivo.

Impossível não agradecer aos meus pais, João e Marta, que sempre me apoiaram e me incentivaram a nunca parar de estudar. Nunca conseguirei retribuir tudo o que vocês fizeram por mim. Muito obrigado!

Aos meus grandes amigos, irmãos e pangarés André, Felipe e Renan, e também à minha querida amiga Natali, que sempre me deram força e também me apoiaram durante o processo de mudança para Joinville.

Agradeço os meus sogros, Ary e Célia, que sempre acreditaram em mim e, também, ao meu cunhado Ary, pela amizade e pela ajuda na mudança em Joinville.

Definitivamente, este trabalho não se realizaria sem o apoio incondicional da minha esposa Vitória, que se desdobrou para me ajudar nos períodos de maior trabalho, que em vários momentos dividiu as nossas tarefas diárias para que eu pudesse me dedicar à pesquisa, que me ajudou a refletir sobre aspectos qualitativos da pesquisa, que mudou de perspectiva para me acompanhar em Joinville... Bella, não existem palavras para expressar o quanto eu sou grato pelo seu apoio e amor. Muito obrigado! Te amo!

Aos grandes músicos Hermeto Pascoal, Sivuca, Astor Piazzolla, Ravi Shankar, Philip Glass e muitíssimos outros gênios pela constante fonte de inspiração. 


\section{Resumo}

BELLUCCO, A. Argumentação Matemática em aulas investigativas de física. 2015. 251 f. Tese (Doutorado) - Faculdade de Educação, Universidade de São Paulo, 2015.

No trabalho a seguir buscamos compreender o papel da matemática na construção dos argumentos dos estudantes em atividades de ensino investigativas. Para o encaminhamento dessa pesquisa, realizamos uma revisão sobre argumentação e argumentação matemática com o intuito de obter elementos para a construção de um instrumento de análise de situações de ensino e aprendizagem. A partir desse estudo emergiu também a necessidade da consideração das diferentes linguagens usadas na comunicação e de observar a qualidade do processo argumentativo em termos de sua forma e conteúdo. Com a estruturação desse quadro teórico, elaboramos uma sequência de ensino investigativa (SEI) sobre quantidade de movimento, sua conservação e as leis de Newton, que agrupa as características encontradas, tal como a abdução, isto é, o uso de uma regra ou lei como hipótese que auxilia na explicação de um fato novo. Para alcançar nossos objetivos, analisamos a gravação em vídeo da aplicação dessa sequência em uma turma do primeiro ano do ensino médio, de uma escola pública do estado de Santa Catarina, com o auxílio do software Videograph, que facilita visualizar a ocorrência das categorias propostas em um gráfico temporal. Verificamos a intensa frequência das propriedades da argumentação destacadas, com um grande movimento das diferentes linguagens na construção dos significados, em especial a algébrica no processo de estimativas. Por outro lado, ficou explícita a desconexão entre fenômenos e suas representações, à medida que os estudantes se distanciaram do problema experimental do início da SEI e se envolveram no processo de resolução de problemas isso demanda o planejamento de atividades específicas para estimular a reflexão sobre essas situações.

Palavras-chave: Argumentação. Linguagens. Matemática. Física. Ensino por Investigação. 


\begin{abstract}
BELLUCCO, A. Mathematical argumentation in inquiring physics classes. 2015. 251 f. Tese (Doutorado) - Faculdade de Educação, Universidade de São Paulo, 2015.

In the following work we seek to understand the role of mathematics in the construction of the arguments of students in inquiry teaching activities. For forwarding this research, we conducted a review about argumentation and mathematical argumentation with the purpose to provide elements for the construction of an analytical tool for teaching and learning situations. From this study also emerged the need for consideration of the different languages used for communication and observe the quality of the argumentative process in terms of its form and content. With the structuration of this theoretical framework, we developed an Inquiry-Based Teaching Sequence (IBTS) about momentum, its conservation and Newton's laws, which brings together the features found, such as abduction, i.e. the use of a rule or law as hypothesis that helps to explain a new fact. To achieve our goals, we analyze the video recording of the application of this sequence in a first year high school class in a public school in the state of Santa Catarina, with the help of Videograph software that makes easy to observe the occurrence of the categories proposed in a temporal graph. We verified the intense frequency of the argument properties highlighted, with a large movement of the different languages in the construction of the meanings, especially the algebraic one on the estimation process. On the other hand, was explicit the disconnection between phenomena and their representations, as students distanced themselves from the experimental problem of the beginning of IBTS and became involved in the problemsolving process - that demand the planning of specific activities to stimulate reflection about these situations.
\end{abstract}

Keywords: Argumentation. Languages. Mathematics. Physics. Inquiry Teaching. 


\section{Sumário}

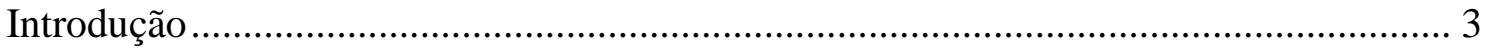

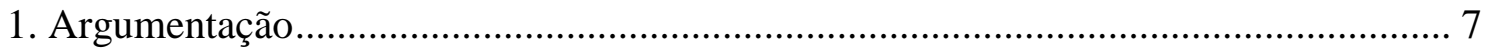

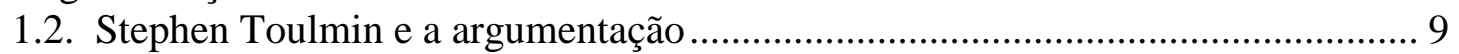

1.3. Argumentação matemática e sua relação com a ciência ...................................... 13

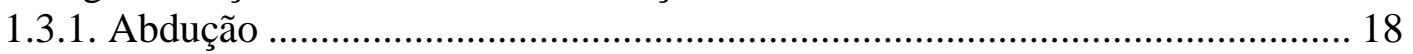

1.3.2. Argumentação matemática, abdução e ensino ............................................ 24

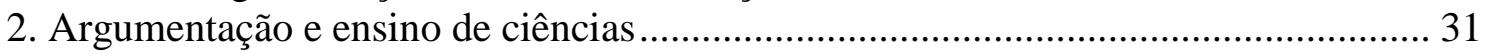

2.1. A importância da argumentação no ensino de ciências ...................................... 31

2.2. Referenciais teóricos para análise do argumento na sala de aula e suas limitações

2.2.1. Perspectivas críticas da argumentação no ensino de ciências ........................ 45

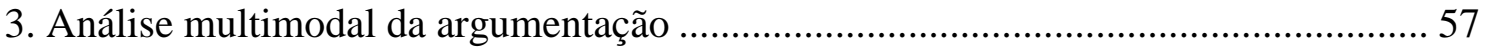

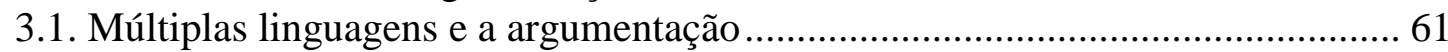

3.1.1. Um exemplo do uso da ferramenta para análise multimodal da argumentação

para análise multimodal da argumentac̃ão

4. Uma ferramenta de análise da argumentação matemática em sala de aula ................ 71

4.1. Avaliando a argumentação matemática em uma aula de física ........................... 71

5. Uma sequência de ensino investigativa sobre quantidade de movimento, sua

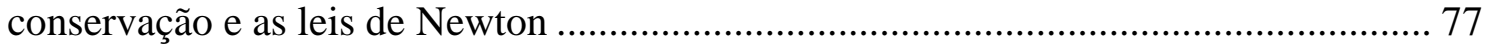

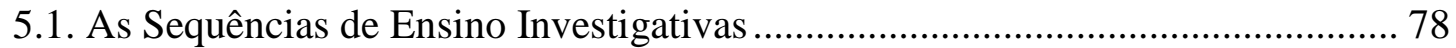

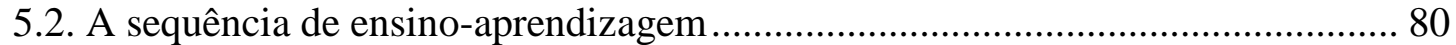

Atividade 1 - Transferindo movimento: o problema do pêndulo de Newton.......... 82

Atividade 2 - O que é quantidade de movimento, afinal? O problema das colisões

Atividade 3 - Problemas abertos...................................................................... 86

Atividade 4 - Conservando os movimentos: as leis de Newton ............................ 87

Atividade 4.1 - Perdidos no Espaço - A primeira lei de Newton ............................ 87

Atividade 4.2 - O que provoca um movimento? Variando a quantidade de

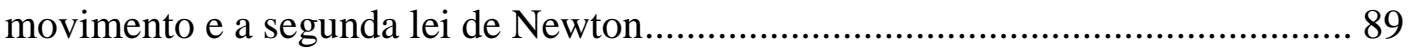

Atividade 4.3 - Interagindo e reagindo: a terceira lei de Newton.......................... 90

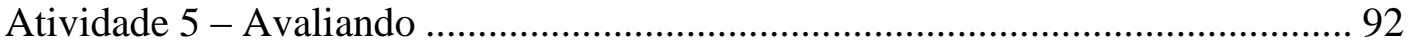

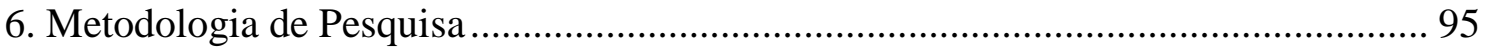

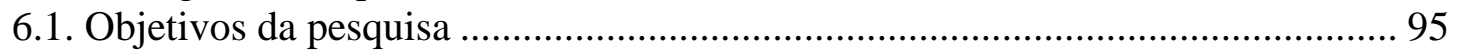

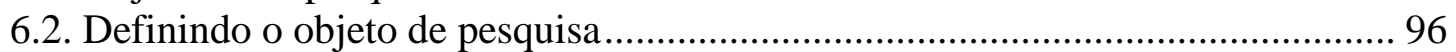

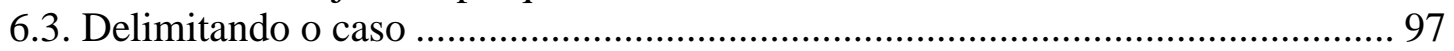

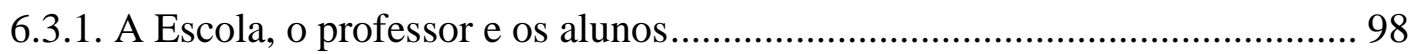

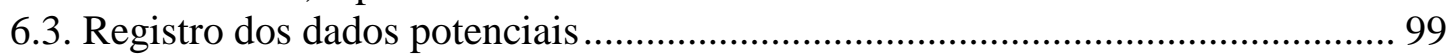

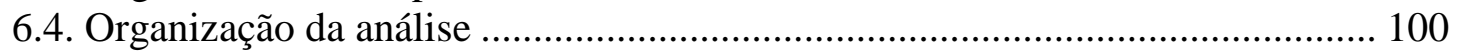

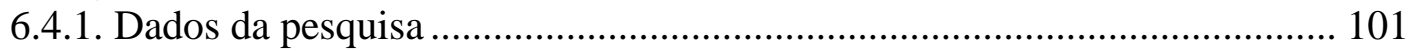

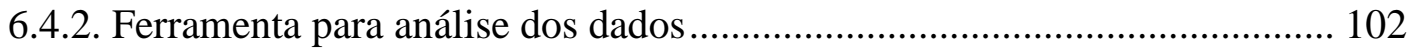

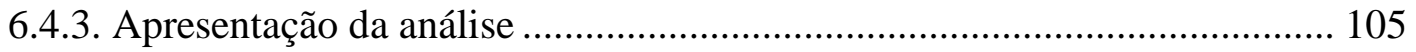

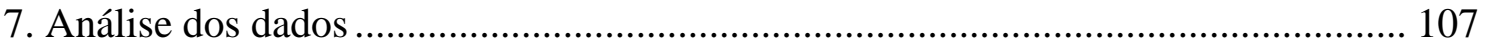

Episódio 1 - Quem tem maior quantidade de movimento? Um problema fechado 107

Episódio 2 - Problemas abertos (atividade 3 da SEI) ............................................. 114

Episódio 3 - Discussão coletiva sobre os problemas abertos .................................. 130

Episódio 4 - Problemas abertos sobre colisões inelásticas.................................... 137

Episódio 5 - Interpretação física dos resultados matemáticos .............................. 147

Episódio 6 - O problema aberto dos astronautas ..................................................... 156

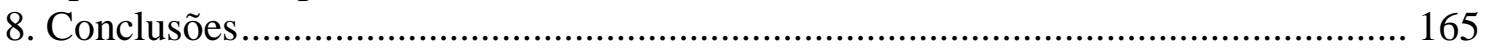


Bibliografia ................................................................................................ 173

ANEXO I - TEXTO DE SISTEMATIZAÇÃO SOBRE CONSERVAÇÃO DA QUANTIDADE DE MOVIMENTO_...................................................................... 179

ANEXO II - EXEMPLO DA VALIDAÇÃO DA SEI ……………………………....... 181

ANEXO III - MODELO DAS AUTORIZAÇÕES DE PESQUISA …………………... 187

ANEXO IV - GRAVANDO: O MICROFONE PZM, O PRÉ-AMPLIFICADOR E A

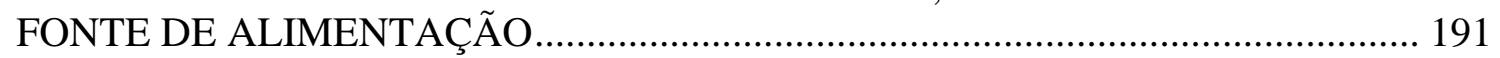

ANEXO V - NORMAS DE TRANSCRIÇÃO............................................................ 197

ANEXO VI - TRANSCRIÇÕES DOS EPISÓDIOS DE ENSINO .............................. 199 


\section{Introdução}

As ideias fundamentais desempenham papel essencial na formulação física. Os livros sobre física estão cheios de complicadas fórmulas matemáticas. Mas o pensamento e as ideias, e não as fórmulas, são o princípio de toda a teoria física. As ideias devem assumir posteriormente a forma matemática de uma teoria quantitativa, para possibilitar a comparação com a experiência (EINSTEIN e INFELD, 2008, p.228).

A frase de Einstein e Infeld ilustra bem um dos principais processos pelo qual o pensamento do cientista pode enveredar na busca por respostas para questões sobre seus objetos de estudo. Ou seja, esse é um caminho pelo qual trilha a aprendizagem do pesquisador e isto leva à questão: e por que não dos estudantes, afinal é uma importante forma de aprender?

Parece-nos sensato que a vivência e a tomada de consciência sobre esse tipo de processo, sejam fundamentais para que os estudantes iniciem sua aprendizagem de conhecimentos científicos, mesmo havendo diferenças entre os centros de pesquisa e as salas de aula.

Por outro lado, os professores, do ensino fundamental ao superior, tem uma tradição em se resguardar atrás de um formalismo matemático excessivo, que seus alunos desconhecem. Sendo assim, os docentes transitam em um terreno "seguro" no qual há um conhecimento certo, exato e que inibe o surgimento e a manifestação de dúvidas pertinentes à situação de ensino. Nesses casos, a matemática geralmente é o ponto de partida do pensamento e está muito distante do seu papel na ciência.

Dessa forma, o ensino de física é permeado por uma "obsessão matemática", a qual muitas vezes exclui a possibilidade de discussão fenomenológica e do papel da matemática no contexto da pesquisa científica.

Essa situação deixa clara a necessidade de um ensino que extrapole a mera memorização de esquemas de resolução de exercícios e que faça o aluno construir sentido para o conhecimento científico que vá além da reprodução de algoritmos.

Nos últimos anos, temos nos aventurado na discussão dos fatores importantes para que a matemática nas aulas de física tenha um significado mais coerente e próximo do seu papel na ciência (BELLUCCO, 2006, 2012; BELLUCCO e CARVALHO, 2009a, 2009b, 2012).

Isso destacou a importância das atividades de ensino investigativas, como forma de trazer à tona o papel do uso da matemática como uma das linguagens da física, 
que ajuda a estruturar e interpretar seus objetos de estudo. Por exemplo, equações que envolvem relações diretamente proporcionais, tão comuns no ensino de física, como $\mathrm{E}=\mathrm{h} \cup$ ou $\mathrm{Q}=\mathrm{mc} \Delta \theta$ devem ser ensinadas em um contexto que mostre/evidencie que elas são usadas para modelar e explicar alguma situação problema, e não como um mero algoritmo sem significado - do tipo "receita de bolo" - para resolver uma classe específica de exercícios de "fixação".

Na medida em que nos aprofundamos nesses temas, vislumbramos o papel do professor como o "intérprete"/“guia" entre a cultura cotidiana e a científica, e entre a linguagem comum e a linguagem especializada usada nos laboratórios (BELLUCCO, 2006). Isso só foi possível devido a uma sequência de ensino investigativa planejada para que houvesse discussão sobre fenômenos a partir de problematizações, possibilitando que eles fossem "traduzidos" e interpretados em linguagem matemática.

Conforme amadurecemos nossas reflexões, verificamos a necessidade de pesquisar como os estudantes engajam-se nas discussões que fundamentam as bases para a compreensão do papel da matemática na física, nesse tipo de atividade de ensino. Esse conhecimento pode ser frutífero no desenvolvimento de estratégias que ajudem os alunos a compreenderem esses temas. Isso dirige nosso olhar para os processos argumentativos, que são fundamentais no contexto da pesquisa científica para a construção e validação dos conhecimentos e, portanto, devem ser considerados em sala de aula se quisermos que os alunos compreendam minimamente os saberes científicos.

Dessa forma, temos por objetivo contribuir para uma análise mais profunda dos processos de ensino-aprendizagem, verificando quais elementos são importantes, na construção dos entendimentos coletivos e individuais sobre os fenômenos físicos em sala de aula. Ou seja, procuramos averiguar quais são as condições para a ocorrência da enculturação científica, que trata da imersão dos estudantes nas práticas, nas linguagens e na comunicação científica, criando condições para que eles ampliem suas visões de mundo (DRIVER et. al., 1999).

Essa situação inevitavelmente envolve a matemática, já que não é possível separar um conceito de sua formulação matemática, ou melhor, a matemática estrutura o pensamento durante a construção dos conhecimentos científicos (PIETROCOLA, 2002).

Portanto, buscamos acompanhar os obstáculos enfrentados pelos estudantes ao se enculturarem nesse processo de estruturação matemática dos conhecimentos científicos em aulas investigativas. 
Destacamos que isso está intimamente relacionado à sequência de ensino, que deve ser delineada para que os alunos argumentem sobre os elementos que conduzem à matematização, e a ação do professor, que introduz cada atividade, constrói o ambiente que propicia as discussões e favorece a síntese dos conhecimentos construídos. Sendo assim, procuramos responder as seguintes questões de pesquisa:

Como o conhecimento matemático é demandado na construção dos argumentos científicos dos estudantes em aulas investigativas de física?

Quais são as dificuldades enfrentadas pelos alunos ao longo desse processo?

Como a linguagem matemática torna-se necessária para a construção dos significados científicos?

Como se dá a apropriação desse conhecimento matemático?

Para resolver as questões acima realizamos no capítulo 1 uma revisão sobre argumentação e argumentação matemática, com o intuito de desvendar parte do papel da matemática na construção e validação dos conhecimentos científicos, buscando implicações para o ensino.

No capítulo 2, discutimos pesquisas que abordam a importância da argumentação tanto na ciência quanto no seu ensino, o que possibilitou agregar características importantes à discussão anterior.

Além disso, como a comunicação extrapola o uso das linguagens oral e escrita, foi necessário realizar uma revisão sobre o papel dos modos de comunicação, ou linguagens, na construção dos conhecimentos científicos (capítulo 3). A sistematização desses conhecimentos levou ao desenvolvimento de uma ferramenta multimodal para o estudo da argumentação matemática em aulas investigativas (capítulo 4).

Esses conhecimentos também nortearam a construção de uma sequência de ensino investigativa (SEI) sobre quantidade de movimento, sua conservação e as leis de Newton, que estimula os alunos a argumentarem matematicamente e que serve como fonte de dados para a presente pesquisa (capítulo 5).

A partir disso, desenvolvemos uma metodologia de pesquisa, capítulo 6, que leva em consideração os conhecimentos sobre argumentação, matemática e linguagens estruturados nos primeiros capítulos. As categorias construídas nesse processo foram estruturadas por meio do software Videograph, que favoreceu o estudo da aplicação da SEI em uma turma do primeiro ano do ensino médio, de uma escola pública do estado de Santa Catarina. 
Realizamos uma análise de parte dessas aulas da SEI no capítulo 7, no qual discutimos minuciosamente as categorias de análise encontradas e a qualidade do processo argumentativo dos episódios de ensino identificados.

No capítulo 8, destacamos os resultados alcançados, que indicam a necessidade do planejamento de atividades específicas para a reflexão da relação entre fenômeno e representação matemática. 


\section{Argumentação}

Frequentemente a argumentação é associada à retórica, que teve origem na época dos pensadores gregos. Não é objetivo do presente trabalho discutir esse histórico e todas as suas inflexões, detalhes e tradições. Por outro lado, situaremos abaixo brevemente esses estudos para contextualizá-los com o intuito de destacar características modernas da argumentação, tanto na ciência quanto no ensino, verificando sua relação com a matemática e buscando uma ferramenta de análise para a argumentação dos estudantes de ciências que envolva a matemática.

Rezende (2010) define a retórica como a arte da persuasão e argumenta que seu resgate teve como principais pensadores Perelman, Toulmin e Meyer, sendo que a retórica geralmente apresenta um sentido pejorativo nos discursos e argumentos, na medida em que se presta ao convencimento a qualquer custo, iludindo e enganando. Em contrapartida, há uma concepção positiva, estabelecida a partir dos trabalhos de Aristóteles, que possui regras próprias e está relacionada a elementos éticos. Essa última visão tinha como principal característica atuar em situações em que existem dúvidas e faltam evidências e certezas.

O autor argumenta que essa visão favorável caiu em desuso devido à influência dos trabalhos de Platão nos principais pensadores ocidentais, especialmente Hobbes e Descartes, que valorizavam a certeza como objetivo final tendo a matemática como modelo científico, repelindo a dúvida e, consequentemente, a retórica como uma forma válida de produção de conhecimento. Ou seja, nessa visão:

\section{Onde há dúvida não se faz ciência, pois é preciso ter certeza, e a retórica não poderia fornecer certezas. Assim, a retórica pode ser pensada, durante um longo período da história do pensamento ocidental, como um saber sujeitado ${ }^{1}$ (REZENDE, op. cit, p. 97).}

Somente a partir do final do século XIX, com a crise da racionalidade cartesiana, ela voltou por meio de diversos autores, que visavam entendê-la por uma perspectiva não cartesiana do saber. Dessa forma, Rezende (op. cit.) faz uma análise dos trabalhos dos principais autores desse contexto: Perelman, Toulmin e Meyer.

É fundamental frisar que no contexto da filosofia da ciência e da matemática, os estudos desses autores são classificados como lógica informal ${ }^{2}$, a qual entendemos

\footnotetext{
${ }^{1}$ Conteúdos históricos mascarados nas sistematizações formais.

2 O nome informal é usado somente para diferenciar da lógica formal, não tendo relação com conhecimentos espontâneos ou informais.
} 
como um sinônimo de teoria da argumentação. Para uma breve ideia sobre esse conhecimento (já que esse não é o foco da presente pesquisa) o contrapomos à lógica formal, que procura validar os argumentos em função das relações entre os seus termos e a dependência entre eles, tal como em uma dedução matemática. Esses processos dedutivos referem-se a uma parte da construção dos conhecimentos científicos, porém, não contemplam a elaboração, o teste, a sistematização e a aplicação de conceitos e princípios para a interpretação e a avaliação de práticas argumentativas e raciocínio, ou seja, aspectos essenciais da construção e validação do conhecimento que a teoria da argumentação procura explicar.

Isso é extremamente relevante para o presente trabalho que envolve a construção e a validação de conhecimentos em sala de aula, assim a perspectiva de análise de nossa pesquisa se dará no contexto da lógica informal, por outro lado, isto não significa que não consideramos a lógica formal importante, que é um conhecimento complementar ao referencial adotado. Além disso, o termo informal aqui não remete a concepções espontâneas - tal como veremos ao longo deste trabalho, a visão do processo argumentativo sob essa ótica da lógica informal é tão complexa e sistemática quanto na lógica formal.

Devido à importância de Stephen Toumin para a área de ensino de ciências, nos deteremos de forma mais detalhada no seu trabalho no tópico a seguir, mas antes comentamos suscintamente aspectos relevantes de Perelman e Meyer, que marcam a necessidade de refletir sobre a produção do conhecimento além da lógica formal.

No trabalho de Perelman, argumenta Rezende (op. cit.), o foco da retórica é analisar argumentos que "arquitetam as decisões, rechaçando a concepção de uma linguagem unívoca, e aceitando a multiplicidade[...]" (p.98), sendo a racionalidade o principal ponto de seu resgate, já que se trata de uma forma de conhecimento que objetiva resolver conflitos e tomar decisões. Dessa forma, a retórica perelmaniana é considerada como a própria argumentação, na qual qualquer interlocutor pode argumentar, além disso, essa teoria visa que as pessoas cheguem a decisões por meio de raciocínios plausíveis e possíveis, não dotados de certezas, estabelecendo conclusões verossímeis. Seu objetivo é aumentar a adesão de certo público a certas teses sem iludilo.

Quanto às ideias de Meyer, Rezende (op. cit.) destaca que esse filósofo considera que toda manifestação discursiva envolve aspectos retóricos, ou seja, discurso e retórica são indissociáveis, definindo esta última como uma "negociação da diferença 
entre os indivíduos sobre uma questão dada" (MEYER, 2007, p.25, apud REZENDE, 2010, grifo nosso) - situação na qual orador, auditório e linguagem tem o mesmo peso. Destaca-se assim o papel da questão como forma de produção de conhecimento:

O enfoque na retórica proposta por Meyer está na existência de uma questão, de uma pergunta. O problema que se levanta é que permite que a negociação entre os indivíduos se estabeleça. Sem uma questão que se coloca, não há debate, nem discussão, nem possibilidade de escolhas contrárias, pois as pessoas teriam um único caminho a seguir e um ponto de vista uniforme (REZENDE, 2010, p. 123).

$\mathrm{O}$ autor mostra também que Meyer considera a retórica como uma forma condensada de argumentação, ou seja, sem demonstrar todos os caminhos do raciocínio para chegar a uma afirmação. Assim, tanto a retórica como a argumentação tem por objetivo persuadir ou convencer.

Dessa forma, fica evidente no trabalho desses autores que podemos considerar a retórica como sinônimo de argumentação, sendo o objetivo dessa prática persuadir o auditório a partir de uma dúvida sobre uma questão. Discutimos a seguir esse tema sob a perspectiva de Stephen Toulmin.

\subsection{Stephen Toulmin e a argumentação}

Uma excelente introdução ao trabalho de Toulmin encontra-se em Rezende (2010) que enfatiza que o autor busca aproximar a lógica da realidade, ou melhor, ao longo do tempo a lógica se distanciou das formas como as pessoas usam argumentos em diferentes campos do conhecimento. Logo:

\footnotetext{
Para Toulmin [...] a questão central é saber como a lógica pode continuar sendo uma ciência formal ao mesmo tempo em que possa ser aplicada para proceder a uma avaliação dos argumentos que são, efetivamente, usados na prática, no cotidiano (REZENDE, op.cit., p. 103).
}

Toulmin considera algumas virtudes de uma abordagem sociológica da lógica, na qual se estuda os hábitos adequados de inferência passados de geração em geração, porém, para ele isso não é suficiente para "dar validade e autoridade a determinadas formas de argumentar" (REZENDE, op. cit., p. 104). Da mesma forma, ao considerar a lógica como tecnologia, tem-se a vantagem de se poder submeter cálculos à crítica e aos estudos lógicos, por outro lado, o homem que faz essas atividades nem sempre é "lógico". 
Assim, para Toulmin as regras da lógica referem-se a "padrões de realização que um homem, ao argumentar, pode alcançar mais ou menos plenamente, e pelos quais seus argumentos podem ser julgados" (TOULMIN, 2006, p.11), ficando clara a relação entre a lógica e a argumentação, ou melhor, a lógica estuda os padrões produzidos durante os processos argumentativos. Ele dedica boa parte de sua obra aos argumentos justificatórios, ou seja, aqueles usados para apoiar alegações tentando corroborá-las (REZENDE, op. cit).

Além disso, Toulmin (2006) distingue argumentos campo-invariáveis (formas e méritos que não variam com o campo) e campo-variáveis (formas e méritos que variam com o campo). Estes últimos são importantes para o nosso trabalho, já que tratamos de um conteúdo específico (argumentação matemática em aulas de física), com características próprias de construção de conhecimento e asserções, como veremos adiante.

Toulmin também postula fases para os argumentos, que partem de um problema ao levantamento de uma série de soluções candidatas à sua resolução, seguido do uso de termos modais que sugerem que determinada solução é plausível (apresentando critérios de uso de um termo e sua força), podendo haver mais de uma que são hierarquizadas por sua credibilidade e fidedignidade (REZENDE, op. cit.). A partir dessas fases, ele destaca uma estrutura geral para os argumentos, sejam de físicos ou matemáticos, filósofos ou juristas, denominados campo-invariáveis, que envolvem termos modais tais como 'não pode' e 'provável'. Eles possuem ainda "uma estrutura invariável (a força de seu argumento) e um elemento variável (o critério de aplicação varia de acordo com o campo)" (REZENDE, op. cit., p. 108).

Em seu livro "Os usos do argumento", no capítulo intitulado "O Layout dos argumentos", Toulmin (2006) apresenta a estrutura "fina" do argumento. Especificamente, o autor mostra como micro argumentos devem ser estruturados para dar validade a uma estrutura maior de um argumento (ou macro argumento) - seu objetivo é descobrir qual é o layout de um argumento logicamente imparcial, ou seja, quais elementos devem estar presentes em qualquer argumento consistente independente do campo de conhecimento.

Para isso, é necessário descobrir quais os tipos de questões que estabelecem conclusões e como considerá-las em uma avaliação racional dos argumentos. Além disso, questiona-se a tradição argumentativa iniciada com Aristóteles que apresenta a 
seguinte microestrutura do argumento: "premissa menor, premissa maior; portanto, conclusão" (REZENDE, op. cit., p.137).

Essas considerações levam-nos a pensar: quais os tipos de questões que podem estabelecer conclusões na ciência? Como seria a estrutura do argumento científico? Seria tão simples como o silogismo aristotélico acima?

Toulmin (op. cit.) apresenta pistas para resolvermos essa problemática, ou melhor, ele busca uma estrutura de análise que possa abarcar esses questionamentos, não só no âmbito da ciência, mas em qualquer situação que haja a produção de argumentos racionais.

Dessa forma, ele apresenta os elementos dessa estrutura, com os mais diversos exemplos, a saber:

- Conclusão ou alegação (C) - ideia a ser estabelecida;

- Dados ou fatos (D) - que são a base para suporte da alegação;

- Garantias (G) - que, no processo de justificação, garantem a relação entre dados e conclusões e podem ser "regras, princípios, licenças de inferência [...]" (p.141). Por exemplo: “dados do tipo D nos dão o direito de tirar as conclusões C[...]" (p.141). Isso mostra que as garantias, além de serem gerais, estão implícitas enquanto os dados são explícitos.

Além desses conceitos, o autor apresenta outros que têm por objetivo explicitar o grau de força que os dados (D) conferem à alegação (C) sob a referência da garantia (G), o que pode estar relacionado, por exemplo, aos limites de validade dessa última:

- Qualificadores modais $(\mathrm{Q})$ - que indica a força atribuída à garantia. Por isso, ele deve ficar ao lado da conclusão que ele qualifica. Geralmente, são representados por um advérbio.

- Refutação (R) - mostra as situações nas quais a autoridade da garantia não tem validade, portanto, ela deve permanecer abaixo do qualificador que é invalidado ou refutado.

- Apoio, backings ou conhecimento básico (B) - o qual confere a autoridade da garantia e depende do campo de conhecimento em questão, assim, ele deve aparecer logo abaixo da garantia. Por consequência, esse componente também geralmente está implícito como a garantia.

De forma esquemática o padrão de argumento do Toulmin ou modelo de Toulmin (TAP) é representado da seguinte forma: 


\section{Padrão de Argumento de Toulmin (TAP)}

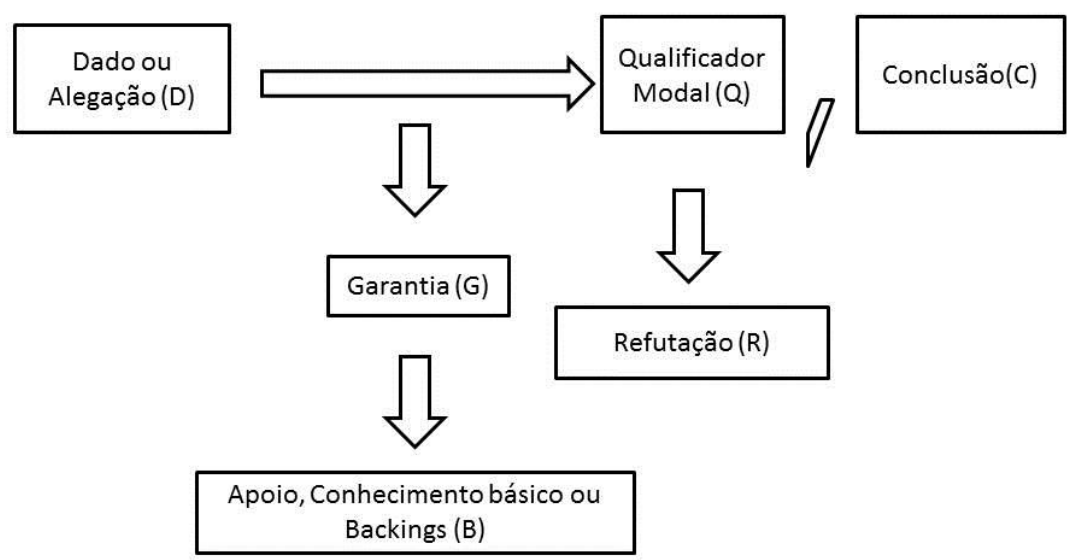

Figura 1: Padrão de Argumento adaptado de Toulmin (2006, p. 150).

Segue um exemplo desse layout apresentado por Toulmin:

\section{TAP - Exemplo}

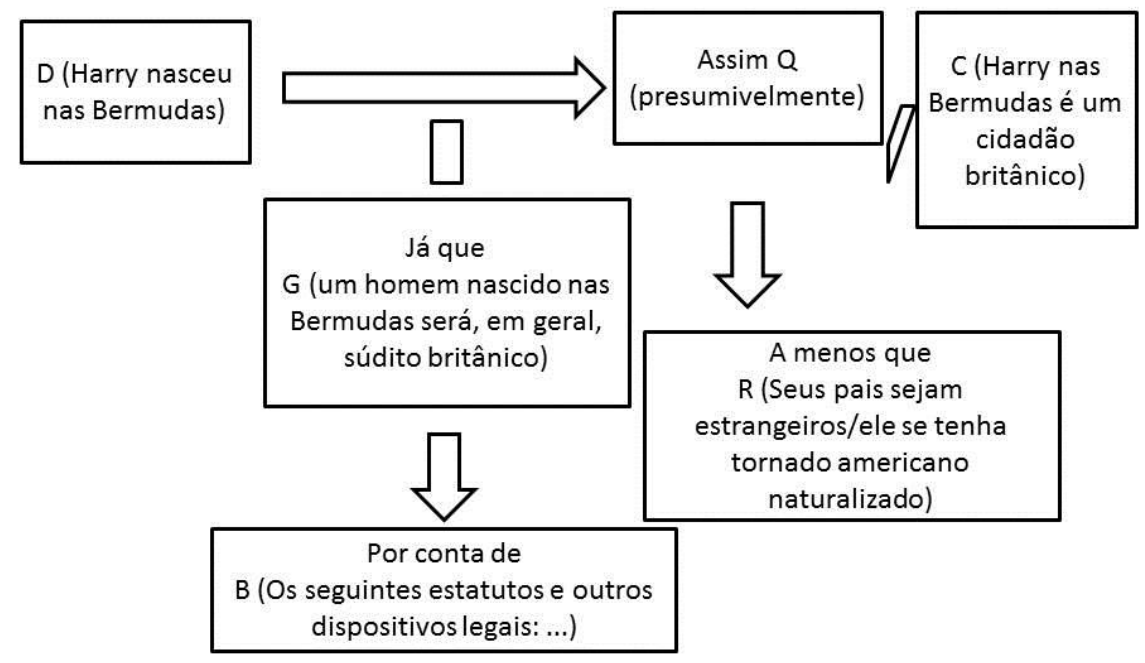

Figura 2: Exemplo do TAP adaptado de Toulmin (2006, p. 151).

Este layout para o argumento, segundo o autor, garante que não haja ambiguidade entre o que é um apoio ou uma garantia, por exemplo, na medida em que explicita tanto a força de uma garantia quanto o conteúdo de seu apoio. Por outro lado, veremos adiante que, no contexto do ensino de ciências, existe uma grande dificuldade em distinguir garantia de apoio na fala dos estudantes. 
Para nossos propósitos no ensino de ciências, é interessante que, ao discutir a validade formal do argumento, Toulmin (op. cit.) mostra o papel das garantias no processo de inferência na Física, ou seja, uma informação geral deve ser interpretada como:

[...] garantia em aberto ou princípio de cálculo; a estabelecemos por testes em situações-amostra nas quais se possam conhecer, independentemente, os dados e as conclusões; que depois serão generalizados por indução e, por fim, serão aplicados como regra de dedução em situações novas para obter novas conclusões de nossos dados (TOULMIN, op. cit., p.174-175).

Voltaremos a essa questão da indução e da dedução mais tarde, quando discutiremos a abdução no processo de argumentação matemática e científica.

De uma forma geral, um argumento é válido quando uma garantia é explicitamente formulada, autorizando o tipo de inferência em questão. Eles podem ser classificados da seguinte forma:

- Analítico - quando estabelece uma garantia, verificando a veracidade da conclusão a ser inferida, no qual o apoio contenha informações sobre a conclusão.

- Substancial - quando o apoio não contém informações sobre a conclusão.

- Conclusivo - estabelece conclusões necessárias, que usam garantias.

- Tentativo - estabelece conclusões prováveis, que geram garantia.

Além disso, os “[...] argumentos analíticos podem ser conclusivos e tentativos, e os conclusivos, analíticos ou substanciais" (TOULMIN, 2006, p.201).

Finalmente, um dos pontos observados no tópico 1 acima é a crítica à argumentação que envolve matemática, que se justifica somente por meio de seus elementos. Logo, veremos a seguir o que os autores que fundamentam seus trabalhos nas ideias de Toulmin discorrem sobre as características desse tipo de argumentação.

\subsection{Argumentação matemática e sua relação com a ciência}

Uma vez que o desenvolvimento da ciência está intimamente relacionado ao desenvolvimento da matemática (KARAM, 2012; LEMKE, 2002; MACHADO, 2009; ROTH, 2003), neste tópico sustentamos uma discussão sobre a argumentação matemática e sua relação com a ciência, destacando aspectos que consideramos essenciais, tal como a abdução, e que devem ser ponderados no ensino de ciências. 
Veremos também que os pesquisadores adotam o referencial de Toulmin para uma descrição mais completa da argumentação matemática (ABERDEIN, 2005 e 2009; DOVE, 2009), que extrapola a visão da lógica formal na qual esse processo é encarado como construção de provas ou argumentos.

Para Aberdein (2009), costuma-se atribuir à filosofia da matemática as bases da matemática e de suas provas, que teria sua metodologia atribuída à lógica formal, na qual a argumentação nesse contexto seria o processo de construir provas. À luz da lógica informal, percebe-se que esse tipo de ideia desconsidera muito das práticas matemáticas, que se fundamentam na argumentação como um processo de justificação, ou seja, ela é definida como atos de comunicação usados para apoiar uma alegação. Sendo que os diferentes tipos de provas podem ser entendidos como argumentos, tais como: provas precedendo modernos padrões de rigor, as provas através de imagens, provas probabilísticas, provas assistidas por computador, provas de livros-texto que são didaticamente úteis, mas não satisfazem um especialista e provas de disciplinas ‘vizinhas' com diferentes padrões/normas, tal como a física-matemática.

Assim, é necessária a argumentação para suportar, por exemplo, a validade de alegações de uma prova estatística (como extrapolar os resultados de uma amostra para a toda população), ou de uma prova computacional (como assumir que estão corretos os cálculos feitos por uma máquina e/ou os algoritmos usados na programação da mesma). No primeiro caso não há como verificar a veracidade da prova sem estudar toda a população alvo. Já no segundo caso, fazer manualmente todos os passos do cálculo computacional levariam muitos anos ou décadas de pesquisa. Destacamos que esses tipos de provas também estão muito presentes na física.

$\mathrm{O}$ autor destaca que no processo de prova há muito mais do que o seu produto:

Talvez o primeiro passo no processo seja a escolha do problema. Embora isso possa ser sujeito a forças sociais e capricho arbitrário, os matemáticos, muitas vezes têm boas razões para escolher os problemas que eles selecionam, mesmo que raramente eles as tornam explícitas [...] Um segundo passo, no qual também é provável que o matemático recorra a argumentos informais é a escolha de métodos usados para resolver o problema. O passo seguinte, a aplicação do método para o problema, pode levar a uma prova, mas esta é susceptível de primeiro tomar forma mais ou menos incompleta de desenhosprova, que já são, no entanto, argumentos. Quando o matemático tem a prova em um estado adequado para a publicação, ela deve sobreviver a uma fase mais explicitamente de argumentação: a dialética entre autor e revisor [...] Uma vez que a prova foi arbitrada e publicada, ela ainda pode ser objeto de argumentação crítica, se seus métodos e resultados são suficientemente controversos. E mesmo depois que se tornou amplamente aceita, se ela atrai interesse suficiente, pode estimular mais argumentos tal como quando os matemáticos procuram generalizá-la, estendê-la, transpô-la para um campo 
diferente, simplificá-la, ou manipulá-la de alguma outra forma (ABERDEIN, op. cit., p.2).

Outro ponto nas práticas matemáticas que são argumentativas, destaca Aberdein (op. cit.), é a seleção de axiomas, que inevitavelmente envolve processos argumentativos, que dependem de sua utilidade em provas formais. A aplicação da matemática na ciência é outra fonte de argumentação, já que as diferenças entre dados empíricos e a teoria matemática é inevitável, e neste momento, a argumentação ajuda a resolver essas diferenças (por exemplo, na justificação da escolha uma determinada curva na aproximação de pontos experimentais a alguma dependência funcional).

Esse último aspecto foi observado também em Bellucco (2006), no contexto do ensino de ciências, no qual foi necessário um processo argumentativo para justificar a escolha de uma função linear em detrimento de outras curvas, como a exponencial e a logarítmica, na descrição do aquecimento da água por uma turma do segundo ano do ensino médio. Além disso, os pontos obtidos no gráfico não formaram uma reta perfeita, o que desencadeou um processo de justificação dos dados empíricos na sala de aula.

Ainda na busca de definir as práticas matemáticas, Aberdein (2009) contrapõe a teoria da argumentação às provas e à lógica dedutiva:

\begin{abstract}
A teoria da argumentação é o estudo do argumento. Em particular, ela destaca os aspectos que resistem à formalização dedutiva. A lógica informal e o pensamento crítico são muitas vezes entendidos como subcampos (ou pseudônimos) da teoria da argumentação. A lógica dedutiva está preocupada com a validade e a prova. Tem sido um programa de pesquisa formidavelmente bem sucedido dentro desse contexto. No entanto, a validade dedutiva é apenas uma ferramenta para a avaliação do argumento. Outras ferramentas existem, incluindo ferramentas que permitam distinções mais pormenorizadas entre os argumentos classificados como dedutivamente inválidos (ABERDEIN, op. cit., p.3).
\end{abstract}

$\mathrm{O}$ autor destaca ainda que os estudos do raciocínio informal estiveram presentes desde Aristóteles e seus seguidores, em pensadores medievais e nos primeiros lógicos modernos, porém, o sucesso da matemática do começo do século vinte ofuscou esses aspectos até a publicação dos trabalhos de Toulmin e Chaim Perelman e Lucie Olbrechts-Tyteca. Além disso, as pesquisas recentes, com forte tendência interdisciplinar, levaram a uma vasta gama de metodologias, que podem ser sumarizadas em três linhas: histórica (análise da argumentação de um trabalho histórico), experimental (reúne dados empíricos de diferentes espécies de investigação ligados ao movimento do pensamento crítico, que tem fortes implicações para a teoria educacional) e avaliativa. 
Dentro desse panorama, Aberdein (2005) mostra que os adeptos da lógica informal afirmam que o sucesso dos lógicos formais, na análise do argumento, se deu à custa de uma aplicação geral desses estudos. Por exemplo, a lógica formal não dá conta da justificação da escolha de um axioma em detrimento de outro em uma prova dedutiva. Assim, os lógicos informais propõem métodos complementares que possibilitam a análise prática das características da argumentação, que não podem ser reduzidos à lógica formal, tal como pontuamos acima. O autor destaca ainda a complementaridade desses conhecimentos na produção do entendimento da matemática e mostra como o padrão de Toulmin pode ser usado para representar argumentos matemáticos regulares e críticos, que não deixam de ser provas matemáticas, revelando vantagens desse método em relação à lógica formal.

Os argumentos regulares fundamentam-se na teoria científica e os críticos em teorias alternativas, porém ambos coexistem normalmente no trabalho dos cientistas. A aplicação do layout de Toulmin no processo de argumentação matemática, pode ser usada para acompanhar a mudança nos padrões de formalidade/rigor desencadeados no processo argumentativo crítico. Nesses casos podem ser usadas garantias fora do campo matemático.

Outra característica do conteúdo matemático tratado por Aberdein (op. cit.) são as provas matemáticas, que não deixam de ser argumentos regulares que também podem ser explicitados -por meio do layout de Toulmin, porém, existe uma dificuldade em enquadrar o argumento quando a prova matemática envolve vários passos e resultados intermediários para chegar à conclusão. Como saída, o autor propõe:

Na maioria das provas matemáticas de múltiplos passos o qualificador (e a
refutação) serão os mesmos a cada passo. Isto nos permite fundir os
esquemas de etapas separadas em um, por combinação dos componentes
especificados dos dados, as garantias (e, se necessário, o apoio) de cada etapa
para produzir uma disposição única para toda a prova. Onde há diferentes
qualificadores para diferentes etapas, a qualificação para toda prova
representaria o grau de certeza de determinado passo (ABERDEIN, op. cit.,
p. 300).

No mesmo sentido, Dove (2009) defende que a tradução para uma linguagem formal não é o método usado pelos matemáticos para acessar o raciocínio matemático, mas a prática real de analisar, avaliar e criticar o raciocínio matemático se aproxima da prática da lógica informal ou a teoria da argumentação. O interesse desse trabalho é trazer uma breve visão da lógica informal na justificação matemática para dar suporte às afirmações, logo, adota-se uma perspectiva toulminiana para os argumentos, criando uma base para justificações dedutivas e não dedutivas. Dove adota a definição de lógica 
informal apresentada por Finocchiaro (1996, apud DOVE, 2009, p. 93): “[...] formulação, testes, sistematização e aplicação de conceitos e princípios para a interpretação, avaliação e prática da argumentação ou raciocínio”.

Dove (op. cit.) também destaca que não é possível analisar o argumento apenas pela lógica formal, situação em que apenas um conceito seria necessário para avaliar de forma dedutiva a sua validade. Nesse contexto, desponta o papel da lógica informal, que teve início com o trabalho de Stephen Toulmin, como reação contra a teoria da lógica formal para avaliação de argumentos. Sendo essa uma área de pesquisa em que há uma empreitada teórica em andamento, com pouca literatura disponível sobre as perspectivas informais para raciocinar em matemática.

Fora do campo da lógica informal não há debate sobre a forma adequada do argumento. Para as pessoas formadas no contexto da lógica formal, esse debate não faz sentido, pois existiria uma definição perfeitamente aceitável desse conceito disponível nos livros textos, ou seja, um argumento é uma sequência de frases, proposições ou fórmulas da qual cada uma delas é ao mesmo tempo uma premissa ou consequência das linhas anteriores e das quais é uma conclusão (tal como em uma dedução matemática). Tal definição não se sustenta em uma análise minuciosa dos argumentos, por exemplo, introduzindo objeções e respostas na estrutura premissa/conclusão, e ainda, ao tentar delimitar o que conta como premissa.

\begin{abstract}
Além das questões de saber se todos os argumentos devem conter elementos dialéticos, outras considerações incluem: se se define o propósito dos argumentos; se os elementos retóricos devem ser considerados na definição de argumento, se um argumento deve ser definido em termos de sua estrutura, etc (DOVE, 2009, p. 139).
\end{abstract}

Além disso, os matemáticos frequentemente usam métodos de prova não dedutivos, tais como provas baseadas em métodos computacionais, cálculos probabilísticos, provas parciais e abdução (ABERDEIN, 2009; DOVE, 2009). Essas práticas produzem também resultados tão precisos quanto os métodos dedutivos e passam por exames ainda mais rigorosos que esses últimos, baseando-se em métodos da lógica informal. Dentre elas destacamos a abdução como um processo central tanto na argumentação matemática quanto na ciência, logo, abordamos esse assunto detalhadamente no tópico 1.3.1. Além disso, esses métodos são apropriados pelos físicos no seu trabalho diário, logo, se almejamos um ensino que aproxima ciência da sala de aula, eles devem ser considerados nas situações didáticas, dessa maneira, também discutimos essas relações adiante. 
Assim sendo, existem práticas matemáticas que não partem de axiomas, e a aceitação desses últimos não se dá por provas dedutivas, mas sim pelo uso da razão - o que envolve considerações sobre o quanto eles são frutíferos para a pesquisa. Sendo assim, a lógica informal é a lógica do raciocínio matemático (ABERDEIN, 2005).

\begin{abstract}
Matemáticos já, embora talvez tacitamente, usam as técnicas da lógica informal. Eles as usam quando avaliam provas, e quando eles acessam o raciocínio matemático que não é provado. Isso não quer dizer que os matemáticos devem prestar mais atenção à lógica informal ou teoria da argumentação. Em vez disso, isto sugere que uma precisa filosofia da matemática deve reconhecer este uso. Assim, na medida em que a lógica informal já é uma parte da prática matemática, faz sentido fazer o uso explícito como parte de um grande projeto de construção de uma filosofia da matemática praticada seriamente (ABERDEIN, op. cit., p.146).
\end{abstract}

Ademais, Aberdein (op. cit.) propõe questionar deduções subjacentes como forma de criticar uma prova, explicitando assim a lógica informal. Tanto a prova quanto a dedução matemática ocorrem por meio da linguagem natural. Assim, a ponte entre dados iniciais e as partes subsequentes do argumento envolvem a lógica informal.

Por fim, fica evidente que no processo de argumentação matemática, principalmente no processo de dedução ao realizar provas, existem elementos que escapam à lógica formal, por exemplo, quando se justifica o uso de um axioma em detrimento de outro ou se justifica um cálculo computacional. E ainda, que a aplicação da matemática na ciência intensifica esse tipo de situação, e o layout/padrão de argumento de Toulmin desponta como uma ferramenta para análise dessas situações.

Iremos agora discutir esquemas de raciocínio que levam ao processo de justificação matemática dos argumentos científicos, tal como a abdução.

\title{
1.3.1. Abdução
}

O conceito de abdução foi desenvolvido por Charles Sanders Pierce (18391914) no período de resgate da retórica discutido nos tópicos anteriores e também foi influenciado por uma visão aristotélica sobre a explicação. Além disso, a abdução desafia a lógica formal, na qual os argumentos são deduzidos por passos interdependentes, como nas deduções matemáticas - situação em que não há espaço para conhecimentos/fatos surpreendentes ou anômalos (RAHMAN, 2007). 
Rahman (2007) define abdução como o processo de construção de hipóteses explanatórias e como uma operação lógica que introduz uma ideia nova. Trata-se de uma inferência sobre algo e a aceitação provisória de uma hipótese explanatória com o intuito de testá-la. Nem sempre essa inferência é a melhor explicação, tal como veremos adiante, porém ela explica ou ao menos esclarece alguma informação surpreendente ou anômala e, para que isso ocorra, é necessária uma revisão de nossas concepções em um caminho plausível e racional.

Pierce (2012) tratou a abdução como um dos três tipos de raciocínios científicos - indutivo, dedutivo e abdutivo:

$\mathrm{Na}$ ciência, há três espécies fundamentalmente diferentes de raciocínio: Dedução [...], Indução [...] e Retrodução ${ }^{3}$ [...] (p.5).

O argumento é de três tipos: Dedução, Indução e Abdução (geralmente denominado de adoção de uma hipótese) (p.30).

Esse autor destaca que:

Abdução é o processo de formação de uma hipótese explanatória. É a única operação lógica que apresenta uma ideia nova, pois a indução nada faz além de determinar um valor, e a dedução meramente desenvolve as consequências necessárias de uma hipótese pura.

A Dedução prova, que algo deve ser; a Indução mostra que alguma coisa é $\underline{\text { realmente operativa; a Abdução simplesmente sugere que alguma coisa pode }}$ $\underline{\operatorname{ser}}(\mathrm{p} .220)$.

Miskulin (1999) traz um exemplo desses raciocínios apresentado por Pierce:

Dedução:

Regra: Todos os feijões deste saco são brancos.

Caso: Estes feijões são deste saco.

Resultado: Estes feijões são brancos.

Indução:

Caso: Estes feijões são deste saco.

Resultado: Estes feijões são brancos.

Regra: Todos os feijões deste saco são brancos.

Abdução:

Regra: Todos os feijões deste saco são brancos.

Resultado: Estes feijões são brancos.

Caso: Estes feijões são deste saco (MISKULIN, op. cit., p.347).

A dedução envolve um movimento do geral para o particular, equivalente ao silogismo, ou seja, um raciocínio com as seguintes proposições: premissa maior (todos os feijões deste saco são brancos), premissa menor (estes feijões são deste saco) e conclusão (estes feijões são brancos). Por outro lado, a indução envolve uma conclusão apoiada em uma inferência, das partes para o todo. Por fim, a abdução envolve a emissão de uma hipótese na elaboração de uma inferência (no caso "Estes feijões são deste saco"), trazendo uma ideia nova (diferente da indução e da dedução) que deve

\footnotetext{
${ }^{3}$ Pierce no início de sua obra usa a palavra retrodução no lugar de abdução.
} 
ser testada por deduções e induções (MISKULIN, op. cit.).

Dessa forma, neste último caso faz-se uma inferência a partir dos dados descritivos sobre algo, incluindo a formulação de uma hipótese que explique consistentemente os dados, procurando testá-la e justificá-la (AMARAL, 2011): "Nesse sentido, alguns autores ressaltam que a busca por uma justificativa não deve priorizar o convencimento, mas, além disso, a explicação" (AMARAL, op. cit., p. 57). No contexto do pensamento matemático destacamos:

Ressalta-se que se concebe o raciocínio abdutivo, como um dos mais importantes raciocínios no processo de se "fazer matemática", pois o sujeito ao resolver problemas, lança mão de inferências e hipóteses, testa-as matematicamente, reformulando suas estratégias e procedimentos, com vistas a atingir seus objetivos e finalizar suas tarefas (MISKOLIN, 1999, p. 348).

Pedemonte e Reid (2011) mostram que abdução é uma área de pesquisa em crescimento e que ela se encontra tanto no processo de prova matemática quanto nas outras atividades dessa disciplina. Eles definem esse conceito como uma inferência a partir de dados que possibilita a construção de uma alegação. Enquanto a prova matemática é dedutiva, a abdução traz uma ideia nova no processo de descobrimento e de conjectura. Enfatizamos que esse processo também é fundamental na ciência como veremos adiante.

Para uma análise dos tipos de abdução que podem aparecer no processo de prova, Pedemonte e Reid (op. cit.) fazem uma revisão dos significados atribuídos por C.S. Pierce a esse conceito ao longo de sua construção pelo mesmo: "ele enfatiza a forma lógica da abdução em que o argumento procede de uma regra e um resultado para um processo" (PEDEMONTE e REID, op. cit., p.282) e trata da abdução como parte do processo de descoberta, que da observação de um fato novo, explica-o. Eles destacam também que inicialmente Pierce trata a abdução como uma hipótese, que pode ser representada por um silogismo do tipo:

\footnotetext{
Hipótese

Qualquer M é, por exemplo, P', P',, P'", etc;

$\mathrm{S}$ é P', P', $\mathrm{P}^{\prime \prime \prime}$, etc;

$\therefore \mathrm{S}$ é provavelmente $\mathrm{M}$.

Aqui, $\mathrm{S}$ é o assunto, um caso específico de interesse, e $\mathrm{P}^{\prime}, \mathrm{P}^{\prime \prime}, \mathrm{P}^{\prime \prime \prime}$ são um número de características do mesmo. Por exemplo, pode-se escrever: Qualquer ave tem o bico duro, põe ovos, e pode andar; Um ornitorrinco tem um bico duro, põe ovos, e pode andar; $\therefore \mathrm{O}$ ornitorrinco é, provavelmente, um pássaro (PEDEMONTE e REID,op. cit.,p.283).
}

O exemplo acima indica uma característica fundamental da abdução: faz parte de um argumento com conclusão plausível, mas não necessariamente correta - exceto 
quanto $\mathrm{P}^{\prime}, \mathrm{P}^{\prime \prime}, \mathrm{P}^{\prime \prime \prime}$ são características exaustivas, esse argumento seria denominado de hipótese formal ou raciocínio a partir da definição.

Outra definição para a abdução, apresentada posteriormente por Pierce, é uma hipótese que introduz uma regra geral por meio de uma suposição para explicar uma observação surpreendente. Ou ainda, quando duas circunstâncias possuem características semelhantes, inferir que existem outras nessas condições, tal como em uma analogia. Neste contexto, retrodução significa a adoção de uma hipótese provisória e hipótese quer dizer algo que parece ser ou é verdadeiro e é capaz de ser comprovado ou refutado em comparação com os fatos disponíveis (PEDEMONTE e REID, op. cit.). Destacamos que isso é uma prática fundamental na física, ou seja, os pesquisadores sempre procuram uma verificação experimental de suas hipóteses, sendo que o próprio Pierce (2012) atenta para este fato:

[...] num certo estágio que constitui o eterno exemplo do raciocínio científico de Kepler, este descobriu que as longitudes observadas de Marte, que durante muito tempo ele tentara inutilmente ajustar a uma órbita, eram tais (dentro dos limites possíveis de erro nas observações) como seriam se Marte se movesse numa elipse. Os fatos apresentavam assim, nesta medida, uma semelhança com os fatos do movimento numa órbita elíptica. Daqui Kepler não partiu para a conclusão de que a órbita era realmente uma elipse, mas isto o levou a inclinar-se para a ideia, de modo a decidi-lo à tentativa de determinar se as predições virtuais sobre as latitudes e paralaxes baseadas nesta hipótese se verificariam ou não. Esta adoção probatória da hipótese era uma Abdução. Uma Abdução é Originária quanto ao fato de ser o único tipo de argumento que começa com uma nova ideia (p. 30, grifos nossos).

Voltando às três etapas do raciocínio científico que se inicia pela abdução, seguida da indução e da dedução, tal como destacado por Pierce (op. cit.), enfatizamos características importantes desses processos que devem ser pontuadas:

A conclusão de uma abdução é plausível, não certa. Abdução prossegue para trás, de um resultado ou consequência de um caso ou antecedente. Abdução explica um fato imprevisível. A conclusão de uma abdução é suscetível de verificação ou refutação por comparação com os fatos. É a primeira etapa de raciocínio científico, seguida de dedução (de outras consequências) e de indução (testando essas consequências) (PEDEMONTE e REID, op. cit., p.284).

Outra definição de abdução apresentada por Pedemonte e Reid (2011) é a de Eco, que se baseia no trabalho de Pierce fazendo algumas distinções bastante úteis, ou seja, ele parte da formulação de que é uma inferência de um caso a partir de uma regra ou resultado, porém, quando a regra não é evidente, há três tipos de abdução: sobrecodificada (overcoded), sobcodificada (undercoded) e criativa.

$\mathrm{Na}$ forma sobrecodificada, o argumentador conhece apenas uma regra pela qual o caso pode seguir. Se a regra não for bem conhecida, antes de inferir o caso, ela terá 
que ser compreendida e a abdução dependerá diretamente da sua forma, sendo caso e regra inversamente relacionados.

Quando há uma escolha entre múltiplas regras gerais tem-se a forma sobcodificada, tal como quando Kepler selecionou a curva elíptica entre várias possíveis (circular, oval, cardioide etc), para descrever o movimento de Marte.

Essas duas formas de abdução são seletivas, que tratam de encontrar a mais apropriada hipótese explanatória a partir de uma série de explicações dadas possíveis (PEDEMONTE e REID, op. cit., p.285) na explicação. Quando não há uma regra geral, o argumentador inventa uma nova regra - situação denominada abdução criativa:

\begin{abstract}
As tentativas dos físicos para dar conta das anomalias na órbita de Mercúrio fornecem exemplos de ambas as abduções sobcodificadas e criativas. É possível explicar as anomalias sobre o movimento dos planetas, fazendo uso das regras já existentes. Uma hipótese proposta deste tipo foi a existência de um planeta desconhecido perto do sol que estava perturbando a órbita de Mercúrio. Neste caso, o argumento trata-se de uma abdução sobcodificada. Muitas dessas hipóteses foram propostas, mas, no final, foi uma abdução criativa, a criação de uma nova regra geral (a teoria da relatividade de Einstein) que deu conta das anomalias com sucesso (PEDEMONTE e REID, op. cit., p.285).
\end{abstract}

Além disso, Pierce destaca o papel fundamental da abdução no processo de descoberta científica, no qual as descobertas de Kepler são o maior exemplo do raciocínio abdutivo, que é central no método de investigação científica (POHJOLA, 2007).

\begin{abstract}
Assim, nunca modificando caprichosamente sua teoria, pelo contrário, tendo sempre um motivo sólido e racional para qualquer modificação que fizesse, tem-se que quando ele finalmente procede a uma modificação - da mais notável simplicidade e racionalidade - que satisfaz exatamente as observações, essa modificação firma-se sobre uma base lógica totalmente diferente da que apresentaria se tivesse sido feita ao acaso, ou de um outro modo que não se sabe qual seja e se tivesse sido encontrada para satisfazer as observações. Kepler demonstra seu aguçado senso lógico no detalhamento do processo total através do qual ele finalmente chega à órbita verdadeira. Este é o maior exemplo de raciocínio retrodutivo jamais visto (Pierce, 2012, p.8).
\end{abstract}

Outros autores também apontam os trabalhos de Kepler como um grande exemplo da abdução. Silva (2007) compara os textos originais desse cientista com os escritos de Pierce a fim de explicitar a natureza da abdução.

Silva (op. cit.) destaca que no texto Astronomia Nova de Kepler, o autor faz uma descrição detalhada, passo a passo, do processo científico que levou à geração e substituição de múltiplas hipóteses explanatórias até chegar à conclusão sobre as órbitas elípticas dos planetas. O processo iniciou-se com a observação de que as longitudes de Marte não se enquadram em uma órbita circular, partindo para a tentativa de diversas formas de explicação até a emissão da hipótese da órbita elíptica. A pesquisadora 
destaca nove razões para Pierce usar esse exemplo: trata-se de uma das maiores descobertas científicas de todos os tempos; Kepler buscava as causas dos fenômenos (ele foi o primeiro astrônomo a procurar tais relações); mostra um método científico que busca as causas dos fenômenos; explicita um método de pensamento; esboça o processo de imaginação; destaca seus erros e acertos; deixa claro sua habilidade de adivinhar; é evidenciado no seu trabalho as qualidades morais requeridas pelo caráter científico; e, por fim, representa uma das mais engenhosas abduções da história da ciência.

A autora ressalta ainda que tal exemplo ilustra o conceito de abdução evidenciando níveis hierárquicos deste último. Um primeiro nível consiste em excluir hipóteses erradas em certo número de possibilidades por tentativa e erro. Em um nível um pouco acima, é escolhida diretamente uma boa solução em um limitado número de possibilidades - caso isso seja feito por acaso estamos no segundo nível ${ }^{4}$ e se for feito por meio de uma suposição encontramo-nos no terceiro nível (algo que consideramos similar ao que Pedemont e Reid, 2011, chamam de abdução sobrecodificada e que descrevemos anteriormente). Quando a escolha envolve um número ilimitado de hipóteses, tem-se o quarto nível quando as hipóteses estão em um mesmo contexto e o quinto nível quando estão em contextos diferentes (em ambos os casos, essas hierarquias se assemelham à abdução sobcodificada citada por Pedemont e Reid, op. cit.). Esquematicamente temos:

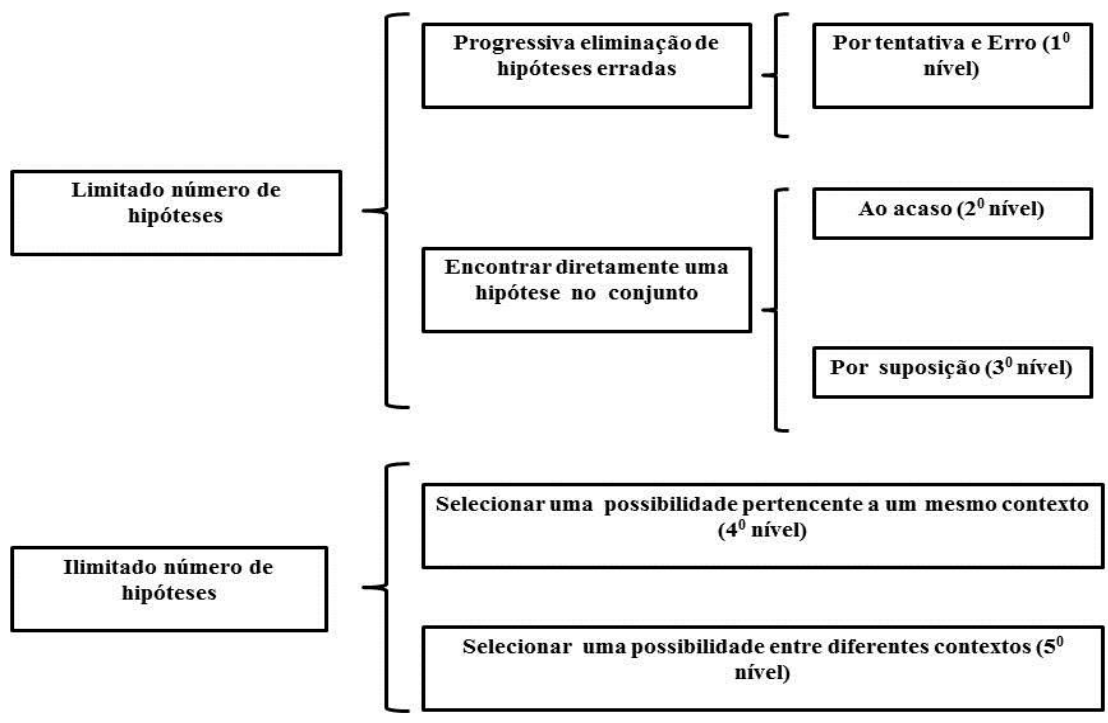

Figura 3: Níveis de abdução - adaptado de Silva (2007).

\footnotetext{
${ }^{4}$ A nosso ver não há diferença entre escolher por tentativa e erro e ao acaso.
} 
Outro exemplo de abdução na ciência é apresentado por Cordovil (2007) e trata do problema enfrentado pelos físicos no início do século vinte para relacionar as características ondulatórias e corpusculares da luz, e ainda, dar conta das órbitas quantizadas dos átomos. Isso foi resolvido por De Broglie ao propor a hipótese de que matéria e luz poderiam ser descritas por algo corpuscular associado a uma onda, possibilitando justificar a quantização do átomo e o caráter dual da luz, além de prever as "ondas de matéria". Geralmente argumenta-se que De Broglie chegou a esses resultados por meio de um raciocínio indutivo, no qual ele "generaliza a hipótese da luzdualista de Einstein para todos os objetos quânticos, chamados, elétrons " (CORDOVIL, op. cit., p.197).

Por outro lado, argumenta Cordovil (op. cit.), naquela época nem mesmo Einstein acreditava que a luz tinha uma natureza corpuscular e ondulatória, ou seja, isto era tratado como uma mera ferramenta prática. Logo, De Broglie assumiu a hipótese quântica da luz como algo real, e, além disso, ele deixou de separar ondas e matéria, assumindo essas características como parte de uma única realidade em nível quântico, a natureza quântica. Essa última hipótese, que assume uma forte analogia entre luz e matéria, não pode ser feita com um raciocínio indutivo ou dedutivo.

Dessa forma, é bem provável que o nascimento da mecânica quântica foi acompanhado de um raciocínio abdutivo: “[...] a formulação da hipótese generalizada dualista onda-corpúsculo [...] e [...] a síntese entre onda e matéria" (CORDOVIL, op. cit., p. 198).

\subsubsection{Argumentação matemática, abdução e ensino}

Vimos anteriormente que a argumentação matemática pode ser estudada à luz do layout de argumento de Toulmin. Além disso, destacamos a importância da abdução tanto na matemática quanto na física, como forma de construção de novos conhecimentos a partir da emissão de hipóteses. Neste tópico sistematizamos como esses saberes se transformam em uma ferramenta de análise em situações de ensinoaprendizagem.

No contexto do ensino de matemática, Inglis et. al. (2007) afirmam que a análise dos argumentos dos estudantes é um tema recorrente na pesquisa em ensino, que 
incide sobre os seus conteúdos e as suas estruturas, sendo estas últimas o foco de análise do artigo. Especificamente eles analisam o interior dos argumentos, a partir do referencial de Toulmin, destacando o papel dos qualificadores modais, caracterizando diferentes formas de argumentação usadas pelos matemáticos.

Eles verificam que nas pesquisas em ensino de matemática, os autores costumam omitir os qualificadores modais e as refutações, chegando até a mencionar sobre um 'padrão ternário' de argumento. Por outro lado, autores de outras áreas usam o padrão completo, mas atribuem valores psicologicamente insignificantes aos qualificadores e refutações, quando na verdade esses elementos estão intimamente relacionados à classificação dos tipos de garantias usados na argumentação matemática. Esse papel é enfatizado ao analisar os argumentos produzidos em entrevistas por talentosos especialistas em matemática, destacando as diferenças entre os argumentos produzidos por eles e os argumentos de não especialistas usando conhecimentos matemáticos.

Nessas entrevistas, em consonância com os referenciais apresentados, os apoios e as refutações frequentemente ficam implícitos na fala dos participantes. Também é muito comum o uso de garantias não dedutivas para deduzir conclusões não absolutas, o que esclarece o papel fundamental que essas formas de argumentação desempenham na resolução de problemas. Além disso:

\begin{abstract}
[...] a omissão do papel do qualificador modal em modelos de argumentos matemáticos nos obriga a considerar os argumentos apenas como conclusões absolutas, e, consequentemente, a subestimar as garantias não dedutivas em matemática avançada [...] talvez o objetivo de instrução não deva ser o traço do raciocínio indutivo ou intuitivo dos argumentos dos alunos, mas garantir que eles qualificam esses tipos de garantia de forma adequada (INGLIS et. al., 2007, p.19).
\end{abstract}

Ainda sob a referência de Toulmin no estudo da argumentação matemática, Pedemonte e Reid (2011) buscam observar os tipos de abdução que facilitam o acesso às provas dedutivas em estudantes. Eles partem da hipótese de que a abdução sobrecodificada (quando uma regra ou garantia é conhecida e usada para inferir um caso ou dado) é mais fácil na construção da prova, desde que a regra usada ou disponível seja suficiente para resolver o problema: "[...] a distância estrutural entre argumentação abdutiva e prova dedutiva é menor porque os alunos só tem que olhar para os dados para justificar a alegação; a regra e a alegação já estão presentes" (PEDEMONTE e REID, op. cit., p.286). 
Já a forma sobcodificada é considerada mais difícil, porque que há várias regras ou garantias disponíveis para resolver o problema (inferir o dado) e caso uma regra não funcione, é necessário mudar de estratégia. A nosso ver, essa forma pode ser bastante frutífera para a introdução e discussão de características essenciais da ciência: como a aproximação de uma curva, as incertezas em uma medida etc.

Por fim, a prova que envolve uma abdução criativa é a mais difícil, pois ela compreende uma verificação cuidadosa da regra criada, e caso isso não seja feito adequadamente, pode-se levar a uma prova falsa.

Com o intuito de analisar a relação entre os diferentes tipos de abdução e as provas nas práticas dos estudantes, Pedemonte e Reid (op. cit.) usam o padrão de argumentação de Toulmin (TAP), destacando o papel dos conhecimentos básicos (B), que no caso tratam da teoria matemática. Ao olhar os processos abdutivos com esse modelo, os dados são considerados uma incógnita, que ao ser encontrada possibilita "[...] aplicar a regra de inferência que justifica a alegação" (p.287):

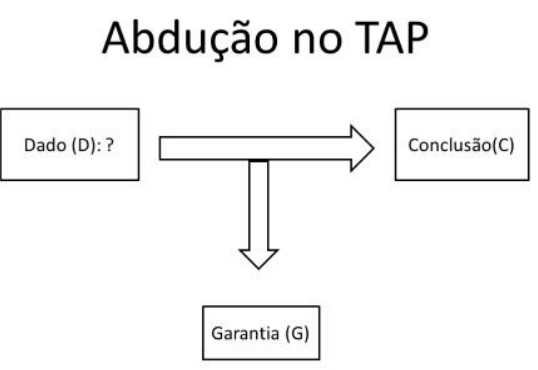

Figura 4: Abdução no TAP (Adaptado de Pedemonte e Reid, op. cit.)

Os autores analisam grupos de alunos tentando resolver um problema geométrico ${ }^{5}$ por meio do uso de um software, situação na qual aparecem os diferentes tipos de abdução. Os conhecimentos básicos guiam os estudantes para encontrar dados ${ }^{6}$ para aplicar os teoremas de congruência de triângulos em uma abdução sobrecodificada. A partir daí, fica fácil construir uma prova dedutiva. Em ambos os casos pode ser aplicado o TAP.

Os estudantes dessa pesquisa têm dificuldades para escolher regras que permitem obter dados para a alegação, logo, eles falham em fazer abdução

\footnotetext{
5 “ABC é um triângulo. Três quadrados exteriores são construídos ao longo dos lados do triângulo. Os pontos livres dos quadrados são conectados, definindo mais três triângulos. Compare as áreas destes triângulos com a área do triângulo ABC” (PEDEMONTE e REID, 2011, p.288).

${ }^{6}$ Isso está de acordo com uma visão adequada da ciência, pois as hipóteses se baseiam nas teorias que o pesquisador domina, evitando assim uma visão empírico-indutivista da ciência.
} 
sobcodificada. Posteriormente, a autoridade do professor fez com que os alunos escolhessem uma regra (envolvendo garantias e conhecimentos básicos), por meio de seu questionamento, transformando uma abdução sobcodificada em sobrecodificada, permitindo a construção de uma subsequente prova dedutiva. Depois, esses estudantes transformaram essa abdução sobrecodificada em duas provas dedutivas.

Com relação à abdução criativa, os alunos apresentam maiores dificuldades, em alguns casos, apesar de se basearem em conhecimentos básicos corretos, usam garantias falsas, resultando em uma prova falsa para o problema. Em outras situações, nesse processo, os discentes construíram corretamente uma nova regra ou garantia para justificar a alegação, baseando-se em conhecimentos básicos empíricos (rotação geométrica das figuras), porém, não puderam se guiar por sua conclusão já que não dispunham de um teorema que a fundamentasse. Assim, eles não conseguiram usar a nova regra na sua prova.

Em outra circunstância, em que os estudantes tinham um problema algébrico, Pedemonte e Reid (op. cit.) mostram que os mesmos partiram de um caso específico para uma regra geral. Isso poderia ser considerado como um processo indutivo, se o caso fosse apoiado por múltiplas instâncias de objetos do mesmo tipo, porém, como o raciocínio baseou-se em apenas um exemplo para chegar a uma regra geral, tem-se uma abdução criativa. Além disso, essa regra foi tratada como teorema pelo estudante, uma vez que ele a usou para resolver outros problemas.

Resumindo, Pedemonte e Reid (2011) mostram que existe grande dificuldade na abdução sobcodificada, principalmente quando ela envolve selecionar conhecimentos básicos diferentes para cada garantia, e também que existem dois tipos de abdução sobcodificada: uma em que há várias regras conhecidas apoiadas em uma teoria e outra mais difícil de ocorrer, em que há várias regras apoiadas em teorias diferentes. A nosso ver, esses níveis de abdução sobcodificada são respectivamente similares aos níveis 4 e 5 descritos por Silva (2007).

No caso da abdução criativa, a dificuldade é ainda maior, visto que não há regras para serem selecionadas (não se conhecem as garantias e conhecimentos básicos) - é necessário criá-las. Dessa forma, há duas dificuldades cognitivas durante o processo de abdução: a primeira é relativa ao próprio processo e a segunda é a de transformar a abdução em uma prova. Ainda no processo criativo, é necessário que a regra criada seja provada ou justificada na argumentação para que os estudantes a reconheçam como teorema, usando-a em sua prova. 
Por fim, os autores mostraram que alguns tipos de abdução facilitam o processo de prova e outros dificultam e que o processo de resolução de problemas antes da prova pode promover o desenvolvimento de abduções, se houver a devida orientação do professor. E ainda, eles elaboram representações dessas escalas abdutivas a partir do padrão de Toulmin, as quais sistematizamos na figura a seguir:

Níveis de Abdução no TAP

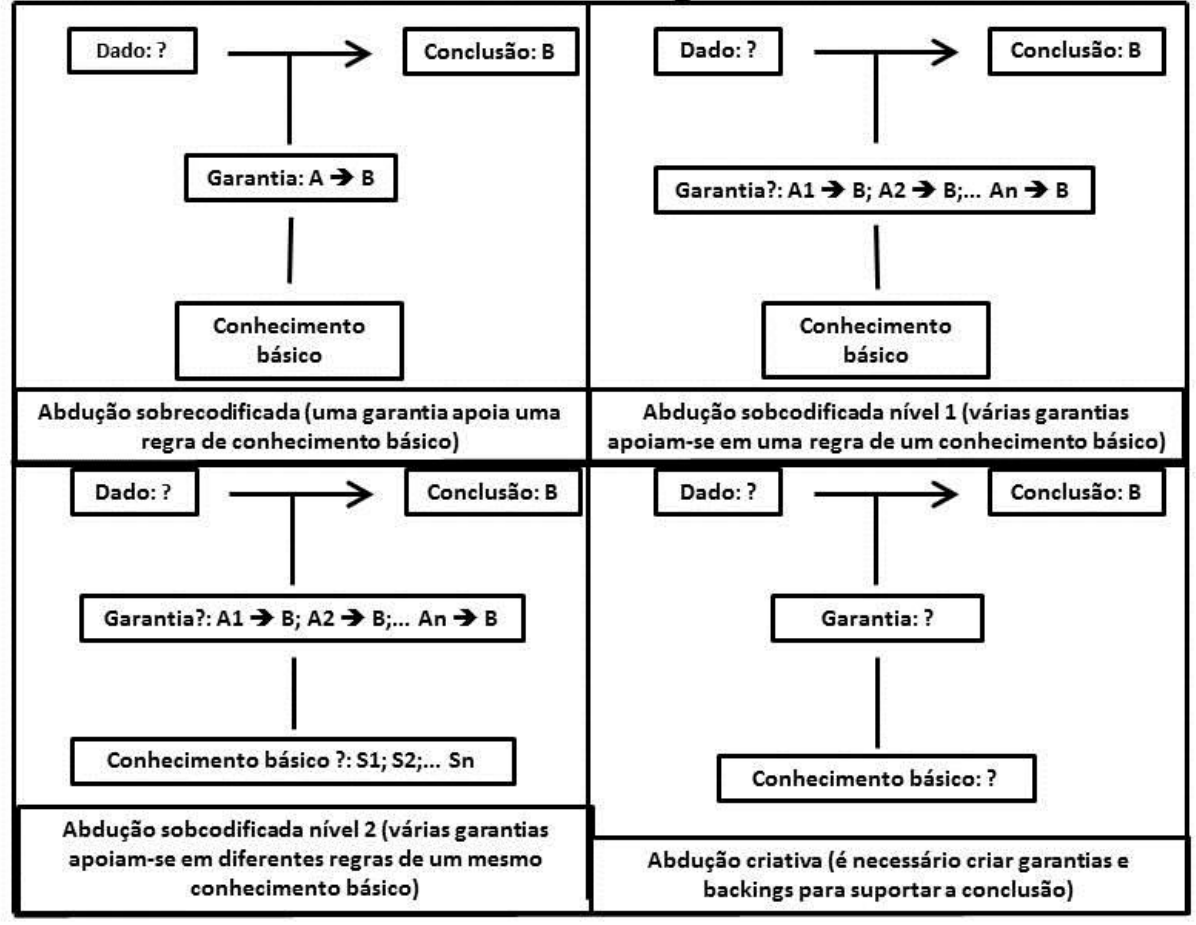

Figura 5: Níveis de abdução (adaptado de PEDEMONTE e REID, 2011).

Nossa hipótese é que essas hierarquias da abdução (tanto aquelas apresentadas por Silva, 2007, quanto essas destacadas por Pedemonte e Reid (op. cit.) podem ser usadas como parte de uma ferramenta de análise de situações de ensino e aprendizagem tanto em aulas de matemática quanto de física, já que esses processos também são observados na física - tal como foi destacado no tópico anterior, ao analisar os exemplos de Kepler e De Broglie.

O quadro da figura 5 é bastante explicativo em relação ao uso da abdução nas diferentes situações. É possível inclusive avaliar o domínio de conhecimentos dos estudantes. Por exemplo, quando há uma abdução sobrecodificada, há um domínio relativo de uma regra ou garantia para inferir um dado que leva à conclusão (o que já é interessante dependendo dos saberes que o contexto exige). Por outro lado, as abduções sobcodificada (níveis 1 e 2) e criativa denotam um domínio de vários conteúdos, no 
primeiro caso inferindo os dados a partir de várias garantias que sustentam a conclusão e no segundo caso criando uma nova garantia que gera os dados para a conclusão, o que significa que o aluno deve olhar criticamente para os conteúdos que ele domina.

Destacamos também o papel dos qualificadores e refutadores no processo de abdução e argumentação matemática, pois eles apontam para características importantes da ciência, como as aproximações, modelizações e limites de aplicação/validade. Assim, o uso desses elementos do argumento denotam uma compreensão implícita da natureza da ciência como uma tentativa de explicar a natureza, ao contrário da visão distorcida como uma verdade exata e final destacada por autores como Gil-Perez et. al. (2001). Sendo assim, é importante observar o uso de qualificadores modais e refutadores que indicam a precisão das alegações, tais como: presumivelmente, a menos que, provavelmente, possivelmente, por outro lado etc.

Destacamos no próximo tópico alguns resultados da pesquisa em ensino de ciências sobre argumentação, que complementam os estudos apresentados anteriormente e que podem auxiliar na construção de um instrumento para interpretar uma situação de ensino-aprendizagem, que auxilie a responder nossas questões iniciais sobre o papel da matemática na construção dos argumentos científicos dos estudantes. 


\section{Argumentação e ensino de ciências}

Nas duas últimas décadas houve uma crescente produção sobre argumentação no ensino de ciências, tanto como uma meta de ensino como uma ferramenta para análise de situações de ensino-aprendizagem. Discutiremos esses dois aspectos a seguir e depois destacamos algumas perspectivas críticas sobre o tema, que ajudam a refletir sobre uma forma de avaliação da qualidade da argumentação matemática no contexto do ensino de ciências.

\subsection{A importância da argumentação no ensino de ciências}

Muitos trabalhos enfocam as interações discursivas na sala de aula na construção da argumentação (CAPECCHI, 2004A, 2004B; JIMÉNEZ-ALEIXANDRE, 2005, JIMÉNEZ-ALEIXANDRE e BUSTAMANTE, 2003; JIMÉNEZ-ALEIXANDRE et. al., 2000; MORTIMER e SCOTT, 2002; NASCIMENTO e VIEIRA, 2009; SASSERON e CARVALHO, 2011A; SOUZA e SASSERON, 2012A, 2012B). Pontuamos alguns deles a seguir com o objetivo de enfatizar a relevância do tema para o ensino de ciências.

Para Nascimento e Vieira (2009), o discurso, ou seja, o meio no qual interlocutores se reconhecem e compartilham ideias entre si, é o espaço de desenvolvimento do processo de argumentação, em que surgirão ideias convergentes e divergentes sobre um argumento. Capecchi (2004b) enfatiza que a superação desse conflito é essencial para construção do conhecimento científico. Nessa situação, ressaltam ambos os autores, é possível vivenciar práticas e discursos da ciência, construir argumentos, desenvolver novas formas de pensar e interagir, além de produzir conhecimento sobre o mundo.

A partir das interações discursivas, o professor pode também estabelecer uma ponte entre a cultura dos alunos, a cultura escolar e a científica, enfatizando os argumentos baseados em justificativas e evidências, típicos da ciência (CAPECCHI, 2004a; JIMÉNEZ-ALEIXANDRE, 2005; SASSERON e CARVALHO, 2011a; SOUZA e SASSERON, 2012a). 
Vieira e Nascimento (2009) destacam a argumentação como um dos elementos do discurso, que é essencial para a compreensão dos processos de ensino e aprendizagem nas salas de aulas:

[...] é bastante compartilhado no meio acadêmico que a participação de alunos em situações argumentativas de sala de aula se relaciona com os seguintes aspectos considerados positivos para a aprendizagem, dentre outros: 1) explicitações de diferentes pontos de vista; 2) crítica mútua de posicionamentos; 3 ) tomadas de consciência dos alunos sobre suas próprias ideias e suas lacunas e inconsistências; 4) tensões e negociações entre os domínios de conhecimento cotidiano e de conhecimento científico; 5) explicitação, construção e reconstrução do pensamento dos alunos (VIEIRA e NASCIMENTO, op. cit., p.83).

Os autores enfatizam que o pensamento está associado a um processo argumentativo, logo, o ato de aprender o pensamento científico relaciona-se às formas de argumentar dessa comunidade. E ainda, que o modelo de Toulmin permite comparar os argumentos científicos com os dos estudantes, que são construídos coletivamente.

Jiménez-Aleixandre et. al. (2000) destacam que a argumentação na sala de aula extrapola apenas a aprendizagem de conteúdos, propiciando raciocínio sobre problemas e questões, justificativas das afirmações científicas e um entendimento da natureza. Por isso, uma aprendizagem que envolve processos argumentativos leva ao conhecimento de como se faz ciência, o que é fundamental para a compreensão do seu papel na sociedade.

Jiménez-Aleixandre e Bustamante (2003) apresentam algumas questões teóricas e metodológicas sobre os discursos em sala de aula e como esses ajudam no entendimento dos processos de aprendizagem de ciências. Os autores definem o discurso introduzido pelo professor na sala de aula como um sistema de comunicação, no qual a linguagem - principalmente a oral - desempenha um papel fundamental para os processos de ensino e aprendizagem e seu entendimento. A comunicação deve possibilitar a construção de significados compartilhados em nível cognitivo e social, o que nem sempre ocorre, pois a linguagem científica pode ter diferentes significados para diferentes pessoas, o que destaca o seu papel interpretativo. A análise do discurso é importante para o estudo desse tipo de questão, na medida em que foca no processo de aprendizagem, e ainda, complementa os estudos sobre concepções prévias que observam o produto do ensino. A partir desse tipo de análise permitiu-se repensar os processos de ensino e aprendizagem em termos não só de conceitos e modelos, mas também incluindo atitudes e destrezas, o que envolve pensar na aprendizagem como participar de uma comunidade, e consequentemente, da cultura científica. Para tal fim, a 
resolução de problemas autênticos, relacionados à vida dos estudantes, tem se mostrado importante.

Dessa forma, no contexto do processo de comunicação em sala de aula, é fundamental o raciocínio e a argumentação, que é entendida como "[...] a capacidade de relacionar dados e conclusões, de avaliar enunciados teóricos a luz de dados empíricos ou procedentes de outras fontes" (JIMÉNEZ-ALEIXANDRE e BUSTAMANTE, op. cit., p. 361). Logo, o ensino de ciências deve promover a capacidade de desenvolver e justificar enunciados e ações com o objetivo de compreender a natureza, ou melhor, deve fazer o aluno raciocinar e argumentar. Essa é uma maneira de ter acesso à forma como o aluno pensa. Os autores destacam que a argumentação na sala de aula não segue um padrão idêntico ao da lógica formal, que foi idealizada para um conhecimento estabelecido, que é diferente de uma situação em que se produz um conhecimento novo. Isto está de acordo com o que discutimos sobre argumentação e abdução no capítulo 1, ou seja, naquela discussão destaca-se que um argumento "formatado" no contexto da lógica formal, como a dedução de uma equação de movimento de um objeto a partir das leis de Newton, justifica-se em termos de seus elementos desconsiderando o seu processo de construção, o qual a mesma lógica formal não consegue justificar - por exemplo, a escolha das condições de contorno que levam àquela equação de movimento específica.

No mesmo sentido, Sasseron e Carvalho (2011b) enfatizam o processo de construção do discurso (não só o oral, mas também, escrito, visual, gráfico etc.), para a compreensão dos processos aprendizagem de ciência, emergindo assim a essencialidade da argumentação, que é entendida como:

[...]todo e qualquer discurso em que aluno e professor apresentam suas opiniões em aula, descrevendo ideias, apresentando hipóteses e evidências, justificando suas ações ou conclusões a que tenham chegado, explicando os resultados alcançados (SASSERON e CAVALHO, op. cit. p.4).

$\mathrm{Na}$ sala de aula, as autoras destacam que as propostas investigativas envolvem resolução de problemas como uma forma de promoção da argumentação e da aprendizagem que envolva uma visão coerente do trabalho científico.

Sasseron (2008), no capítulo 2 de sua tese, intitulado Argumentação no Ensino de Ciências, apresenta uma revisão sobre os trabalhos que envolvem esse tema, pois essa habilidade se dá a partir dos diversos discursos (oral, escrito, visual, gestual etc.) utilizados no processo de Alfabetização Científica desenvolvido na sala de aula. 
Inicialmente, a autora destaca características desses discursos na aprendizagem de ciências, que é facilitada por meio de processos de ensino investigativos.

A primeira característica marcante apresentada por ela, fundamentada nos estudos de Lemke (1997 e 1998), é que os diversos discursos não ocorrem isoladamente, mas se integram, muitas vezes de novas maneiras, para a construção de significados. Consequentemente, para se entender uma linguagem, não basta conhecer as palavras que a constituem, deve-se conhecer as suas relações (inclusive com outras linguagens). Ressalta-se ainda a fala como forma de expressar o raciocínio no ensino e sua aprendizagem, em um processo (que pode ser interpretativo ou transmissivo) que culmina na criação de um novo significado para uma palavra.

É importante destacar que as crianças já possuem uma estrutura de discurso com elementos do conhecimento científico, que para ser entendido, precisa da (re)significação de palavras por meio dos diálogos em sala de aula. Para isso, é fundamental que os alunos questionem, expliquem, construam hipóteses, testem-nas, relevem evidências e informações, deduzam, compartilhem e debatam ideias e tomem decisões, enfim, argumentem.

Neste ponto, Sasseron (op.cit.) volta sua atenção para o uso de imagens e escrita principalmente por meio do trabalho de Márquez, Izquierdo e Espinet (2003), ou melhor, a autora enfatiza importantes modos de comunicação, que se integram a linguagem oral na construção de significados nas aulas de ciência e podem ser ilustrados (cooperados) ou especializados, ou seja, respectivamente podem reforçar um significado ou trazer uma informação nova à fala ou à escrita.

É notável como a sucessiva variação dos modos de significação pode auxiliar o desenvolvimento de uma ponte entre o conhecimento prático/concreto $\mathrm{e}$ as representações abstratas, tal como observado em Bellucco e Carvalho (2009a e 2009b). Dentro desse contexto, é importante o entendimento e o uso dos processos argumentativos na sala de aula, para além da exploração simples dos fenômenos.

Finalmente, Sandoval e Millwood (2007) destacam que a argumentação está no cerne das práticas científicas e, por isso, deve ser considerada no ensino de ciências. Além disso, a compreensão de suas normas permite aos estudantes perceberem aspectos essenciais da epistemologia da ciência.

Em suma, a partir das ideias dos autores citados previamente, verificamos que a consideração da argumentação no ensino de ciências pode potencializar o processo de significação pessoal dos conceitos e o raciocínio científico, estimulando o 
desenvolvimento da cognição e a alfabetização científica, além de promover uma melhor compreensão da natureza da ciência e suas linguagens, ao colocar os estudantes em situações de produção de conhecimento próximas às da ciência. Isso favorece também a vivência da cultura científica e suas práticas, tal como criar e justificar enunciados sobre os fenômenos físicos.

$\mathrm{Na}$ maioria dos trabalhos apresentados acima, é fundamental frisar que os autores ressaltam o papel das atividades investigativas como elemento para desencadear as situações argumentativas em sala de aula e, portanto, a aprendizagem.

\subsection{Referenciais teóricos para análise do argumento na sala de aula e suas limitações}

Em vista da importância da argumentação para aprendizagem de ciências, destacamos aqui alguns proeminentes referenciais teóricos para sua análise em sala de aula (Erduran, 2007; Jiménez-Aleixandre et. al., 2000; Jiménez-Aleixandre e Bustamante, 2003; Nascimento e Vieira, 2009; Sampson et. al., 2012; Sasseron, 2008; Sasseron e Carvalho, 2011a e 2011b; Vieira e Nascimento, 2008 e 2009), de forma a obter elementos na construção de uma ferramenta para interpretar o processo de argumentação matemática em aulas de física.

Sasseron e Carvalho (2011a) discutem como são produzidas as argumentações orais em uma sala de aula de ciências do ensino fundamental por meio de atividades investigativas e quais elementos estão agregados tanto aos argumentos quanto a sua construção. Tal análise tem por objetivo conhecer os processos que desencadeiam na sala de aula a abordagem de um tema científico e quais relações são elaboradas para o seu entendimento.

Assim, surge a necessidade de se considerar a estrutura do argumento - que tem como referência o padrão desenvolvido por Toulmin (2006) - e sua qualidade. Esse padrão é importante para a análise da validade de um argumento construído em uma situação de ensino-aprendizagem. 
O padrão de argumento de Toulmin ( TAP $^{7}$ ) é amplamente usado nas pesquisas em educação e, segundo Vieira e Nascimento (2008 e 2009) e Nascimento e Vieira (2009), é um ótimo instrumento para avaliar o discurso científico na sala de aula, possibilitando distinguir entre situações explicativas e argumentativas, já que ele é prático na visualização de momentos de contraposição de ideias e de sua justificação recíproca. Vieira e Nascimento (2008) apontam algumas limitações do TAP, que não excluem a validade do seu uso na pesquisa em ensino de ciências, posição que estamos de acordo. Com base em uma revisão de literatura, eles destacam que o padrão não considera o contexto de construção do argumento e a sua precisão, além de sua construção coletiva, porém, ele permite uma visão geral da situação argumentativa e seus nuances.

Sasseron (2008) apresenta dois aspectos para a análise da argumentação em sala de aula:

- Estrutura do argumento - na qual destaca-se o padrão de Toulmin como forma de visualizar o estabelecimento de conclusões a partir da produção de argumentos e na sala de aula esse padrão ocorrerá com o somatório de diversas contribuições. Outro padrão de argumento importante é o hipotético-dedutivo proposto por Lawson, que diz que os passos da investigação científica podem ser enquadrados no padrão se/então/portanto, que põem em evidência o importante papel das hipóteses e seus testes na construção do conhecimento, visto que elas envolvem o uso e transferência de analogias. Caso a conclusão não seja atingida, novas hipóteses podem ser adicionadas, gerando outro ciclo hipotético-dedutivo, amparado pelos conectivos 'e' e 'mas'. Por último, a autora destaca as estruturas epistemológicas para análise mais profunda das operações argumentativas: dedução, causalidade, definição, classificação, apelo a, consistência e plausibilidade.

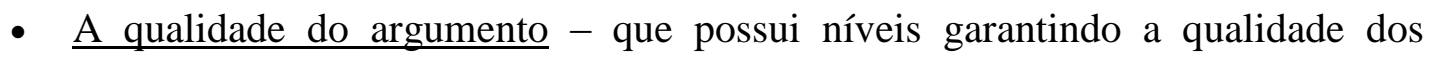
discursos na comunidade científica, o que é importante na sala de aula para introduzir os estudantes nessa cultura e deve aparecer no ensino por meio da resolução de problemas. Os níveis vão desde uma afirmação sem justificativa até afirmações com justificativas respondendo a um refutador e fazer julgamentos integrando diferentes argumentos.

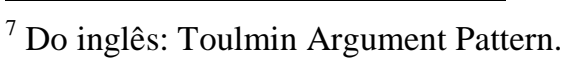


Jiménez-Aleixandre et. al. (2000) procuram estudar como produzir discursos em atividades de ensino que favoreçam o gênero argumentativo da linguagem, levando a aprender sobre como fazer e falar ciência. O foco se dá em alunos trabalhando em grupos em atividades de investigação científica e na distinção entre momentos em que se faz escola - realização de atividades sem objetivo científico e às vezes até pedagógico - e que se faz ciência - atividades em que ocorre o diálogo científico ou a argumentação, ou seja, em que se usa o raciocínio científico para defender/justificar uma ideia em detrimento de outra na construção do conhecimento. Daí a importância da resolução de problemas para a promoção da argumentação. A análise tem ainda o objetivo de evidenciar novas formas de produzir o currículo e suas atividades para promover a argumentação e o entendimento científico.

Os autores detalham teoricamente a argumentação, que possui três formas presentes na ciência: analítica (que inclui a indução e a dedução até uma conclusão), dialética (típica dos debates, que envolvem premissas que não estão visivelmente corretas) e retórica (oratória persuasiva). Destaca-se bastante o modelo de Stephen Toulmin para avaliar argumentos, como uma ótima ferramenta para analisar a sala de aula - mais especificamente grupos de alunos do ensino médio resolvendo problemas de genética - nos momentos de fazer ciência (buscando conhecer as operações características da argumentação nesse período e suas relações), fazer escola e fazer lição. Por último, busca-se compreender qual o grau de entendimento epistemológico da ciência que as atividades proporcionam.

As aulas foram quase todas conduzidas como planejado pela professora, que tentou transferir a responsabilidade do aprendizado aos alunos e nem sempre foi bem sucedida, por exemplo, às vezes ela não deu tempo suficiente para o teste de hipóteses e inseriu questões que só tinham uma resposta. Apenas as duas últimas aulas foram planejadas pelos pesquisadores, que inseriram um problema real para resolução em pequenos grupos.

Os momentos das aulas de falar ciência foram classificados segundo Lemke (1990), que inclui: os estudantes perguntando, informando-se individualmente ou em grupo, discutindo com seus colegas ou em pequeno grupo e escrevendo depois de discussões orais (essa última característica não foi encontrada). Nesses momentos, buscou-se separar a cultura escolar, que envolve o fazendo lição como exposição processual e o agindo como estudantes, e a cultura científica, envolvendo o fazer e o falar ciência, em que respectivamente, identificaram-se as operações argumentativas e 
construção científica localizando operações epistemológicas (dedução; indução; causalidade; definição; o uso de analogias, exemplos, atributos e autoridade; consistência com outros conhecimentos, com a experiência, com o compromisso com a consistência e com a metafísica e plausibilidade). Os períodos de argumentação foram analisados pelo padrão de Toulmin.

É notável nesse trabalho como a inserção de uma atividade investigativa de resolução de problemas pode propiciar a oportunidade de falar ciência, logo, nessa situação o fazer escola fica em segundo plano. Dessa forma, a produção de argumentos foi intensa, sendo alguns bem complexos. Além disso, as operações epistemológicas como a causalidade, o uso de analogias, o apelo à coerência, a universalidade do pensamento etc - foram bastante frequentes ao longo da aula.

Finalizando, Jiménez-Aleixandre et. al. (op. cit.) afirmam que para que os objetivos propostos sejam alcançados é indispensável um ensino por investigação, no qual os estudantes se acostumem a trabalhar em grupos. Para a análise desse ensino, o modelo de Toulmin se mostra útil e ao mesmo tempo insuficiente, por isso, a necessidade do uso de operações epistemológicas para estudar as analogias e o apelo à coerência.

Para estudar argumentação na sala de aula, Jiménez-Aleixandre e Bustamante (2003) mostram que é necessário direcionar as atenções à natureza dos enunciados e sua função no discurso, focando nas formas como se constroem as explicações nas aulas. Neste ponto, os autores formulam importantes questões que continuam a preocupar os pesquisadores desse campo (Erduran, 2007), por exemplo: o que conta como dado, justificação ou conclusão na argumentação? Quando usar a justificação? Quais tipos? A resposta a essas questões contém um componente subjetivo, pois há diferenças entre as interpretações de distintos pesquisadores. Dessa maneira, os problemas metodológicos da análise do discurso são complexos e demandam conhecimentos de outras ciências sociais, como a antropologia, a etnografia ou a sociologia, para identificar, por exemplo, o que é típico da ciência em uma aula. Isto implica na análise de transcrições e registros das situações de ensino e, para estudar o argumento relacionado ao conhecimento científico (substantivo), destaca-se o modelo de Toulmin. É também considerado como limite do argumento extratos de diálogos que contenham a mesma conclusão e sua qualidade - que é maior quando se usam justificativas. Destaca-se a importância dos diagramas para esses estudos. 
Os autores definem ainda algumas operações que podem ser identificadas nos enunciados discursivos argumentativos na sala de aula, que estão relacionadas à construção do conhecimento - chamadas de epistêmicas - ou a exibição procedimental, ou ações dramatúrgicas - chamadas de cultura escolar. Para a primeira classificação apresentam-se os seguintes exemplos: “[...] procedimentos explicativos, definições, classificações, relações causais, apelo a analogias ou comparações, ou construção de dados" (JIMÉNEZ-ALEIXANDRE e BUSTAMANTE, 2003. p.366). Elas costumam aparecer bastante em atividades de laboratório e são usadas para determinar os passos para transformar dados em explicações teóricas, o que é útil para determinar o progresso dos estudantes. Na segunda classificação encontram-se tarefas burocráticas rotineiras da sala de aula, como fazer lição mecanicamente para receber uma nota adequada, tal como apontado em Jiménez-Aleixandre et. al. (2000).

Finalmente, Jiménez-Aleixandre e Bustamante (op. cit.) apresentam algumas tendências para o ensino de ciências, como incluir em seus objetivos a capacidade de argumentação, possibilitando que os estudantes se engajem no discurso científico da sala de aula, o que implica em uma ampliação da visão de como se aprende tais conteúdos. Daí a importância da resolução de problemas, tendo sempre em conta: “[...] a reflexão sobre o caminho seguido, a justificação das ações ou propostas e especialmente a análise das dificuldades que as tarefas abertas apresentam ao alunado" (p.367). Existem também dificuldades nos estudos do discurso que devem ser consideradas: de caráter teórico (análise interpretativa, combinação de diferentes métodos e fontes de dados) e de caráter metodológico (gravações de aulas, trabalhar com alunos que não falam e realizar estudos longitudinais). Os autores destacam por último alguns desafios como: entender como se aprende a raciocinar, a dependência entre argumentação e conteúdo, a continuidade do currículo e a relação das intenções dos professores e suas estratégias.

Na sala de aula, Sasseron e Carvalho (2011b) evidenciam a importância das propostas investigativas que envolvem resolução de problemas como forma de promoção da argumentação e da aprendizagem que compreenda uma visão coerente do trabalho científico. Neste sentido, são importantes os trabalhos baseados na perspectiva da Alfabetização Científica (AC), que as autoras classificam em três eixos estruturantes fundamentados em ampla literatura:

[...] a compreensão básica de conceitos científicos, a compreensão da natureza das ciências e dos fatores éticos e políticos que circundam sua 
prática e o entendimento das relações existentes entre ciência, tecnologia, sociedade e meio-ambiente" (SASSERON e CARVALHO, op. cit. p.5).

Para observar esses eixos e o processo de AC, Sasseron e Carvalho (op. cit.) apresentam os chamados indicadores de Alfabetização Científica, que representam ações e habilidades utilizadas na medida em que se resolve um problema, são eles: levantamento e teste de hipóteses; seriação, classificação e organização de informações; explicação; justificativa, previsão, raciocínio lógico e proporcional.

Os dados para tal análise foram fornecidos pela filmagem de uma sequência de ensino investigativa (SEI), aplicada nas aulas de ciências de uma turma do terceiro ano do ensino fundamental em uma escola pública. As atividades foram planejadas para haver o contato com temas científicos (nesse caso Navegação e Meio Ambiente), o uso de sua tecnologia e suas implicações, englobando suas dimensões sociais e ambientais.

No decorrer do estudo dos dados, observando a ocorrência dos indicadores propostos e do padrão de Toulmin, as autoras verificaram que as explicações dos alunos se baseiam em conhecimentos previamente construídos na sequência de ensino, conferindo alta coerência interna a elas. Além disso, as ideias em questão extrapolam a atividade de ensino para novas situações, mostrando habilidades investigativas desenvolvidas pelos alunos. Isso deixa clara a existência de um ciclo argumentativo, definido como: “[...] a forma por meio da qual as argumentações se desencadeiam e a maneira como as relações entre diferentes dados e variáveis são estabelecidas" (p.13). A partir disso, foi possível desenvolver alguns passos para o ciclo argumentativo:

- Cuidado com os dados existentes: ordenar as informações para destacar sua devida importância durante a investigação, na discussão com os pares, utilizando conhecimentos previamente adquiridos.

- Definição das variáveis relevantes ao problema: envolve também a formulação de hipóteses, o uso de justificativas e previsões, validando e extrapolando as informações teóricas ou experimentais do contexto.

- Explicação: uso das construções elaboradas para relacionar as informações e as variáveis, obtendo uma ideia mais concreta sobre os fenômenos e previsões em questão.

Por fim, as autoras destacam a relação entre os indicadores de alfabetização científica e o modelo de Toulmin, ou seja, há uma relação intensa entre o trabalho com informações (p.e. organização, seriação ou classificação) e conhecimentos básicos (alicerce das ideias e argumentos dos alunos) - que permite a percepção e compreensão 
da relação entre variáveis do fenômeno em estudo, possibilitando o uso de alegações (dados). Esses últimos relacionam-se às hipóteses, que apresentam a ideia a ser construída $^{8}$. Já a conclusão (que não precisa de um sentido em si, mas sim na relação com os elementos do padrão do argumento) aparece na compreensão da explicação, que contrariamente ao modelo de Toulmin, revela relações construídas ao longo de uma colocação. Na relação entre dados e conclusão, há uma ligação entre as garantias e o indicador justificativa. Desempenhando o papel dos qualificadores modais encontrase a previsão.

Uma ferramenta que procura englobar os diferentes aspectos da argumentação, sistematizando os diferentes resultados das pesquisas sobre o tema é apresentada por Sampson et. al. (2012). Segundo os autores, a argumentação constitui a essência das práticas de construção, avaliação e validação do conhecimento científico, porém poucos estudantes têm oportunidade de ensaiar o uso desse discurso, o que levou à elaboração de várias propostas que tentam sanar esse problema. Por outro lado, ainda persistem as dificuldades de avaliar a natureza ou qualidade e a evolução da argumentação científica dos estudantes, realizadas nas pesquisas ao gravar, filmar, transcrever e codificar para analisar a natureza e a função das diferentes contribuições:

Em primeiro lugar, este tipo de análise é muitas vezes demorado e caro. Como resultado, os pesquisadores tendem a estudar pequenas amostras de estudantes ou se concentrar em um determinado contexto. Em segundo lugar, os vários aspectos de um argumento verbal são muitas vezes difíceis de identificar durante uma conversa, o que, por sua vez, tende a ter um efeito adverso sobre a confiabilidade (ver Duschl, 2007; Erduran, 2007; Erduran, Simon et al, 2004) . Outra barreira a este tipo de abordagem é a natureza nãolinear da argumentação científica, que muitas vezes faz com que seja difícil para os pesquisadores seguirem uma linha ou pensamento através de um episódio de uma argumentação de múltiplas vozes ou para definir os limites de uma unidade de análise. Uma análise que incide sobre a natureza ou das funções das contribuições para uma discussão (por exemplo, o número de vezes que os alunos justificam as suas alegações ou desafiam as ideias dos outros, etc) também limita o que os pesquisadores são capazes de medir e obriga-os a ignorar aspectos de argumentação científica que podem ser importantes ou informativos (SAMPSON et. al., op. cit., p. 236).

Dessa forma, surge a necessidade de criar um instrumento que permita aos pesquisadores fazerem uma análise mais ampla e completa sobre a qualidade da argumentação, possibilitando uma referência criteriosa da medida da competência dos estudantes nessa prática. Os autores propõem uma ferramenta denominada Avaliação da Argumentação Científica dentro da Sala de Aula ${ }^{9}$ (AACS), para julgar a qualidade e a

\footnotetext{
${ }^{8}$ Vale ressaltar que isto está de acordo com a discussão apresentada no capítulo 1 sobre a abdução, que trata da emissão de uma hipótese para explicar um conhecimento novo.

${ }^{9}$ Tradução de Assessment of Scientific Argumentation inside the Classroom (ASAC).
} 
natureza da argumentação em sala de aula, objetivando prover uma ferramenta minuciosa como base para observar os aspectos conceituais, cognitivos, epistêmicos e sociais da argumentação. O quadro a seguir resume esse instrumento:

\begin{tabular}{|c|c|c|}
\hline $\begin{array}{l}\text { Aspectos conceituais e } \\
\text { cognitivos }\end{array}$ & Aspectos epistêmicos & Aspectos sociais \\
\hline $\begin{array}{l}\text { 1. A conversa centrou-se na } \\
\text { geração ou validação de } \\
\text { alegações ou explicações. }\end{array}$ & $\begin{array}{l}\text { 8. Os participantes invocaram } \\
\text { as "ferramentas da retórica" } \\
\text { para apoiar ou contestar ideias. }\end{array}$ & $\begin{array}{l}\text { 15. Os participantes foram } \\
\text { reflexivos sobre o que e como } \\
\text { conhecem. }\end{array}$ \\
\hline $\begin{array}{l}\text { 2. Os participantes procuram e } \\
\text { discutem conclusões e } \\
\text { explicações alternativas }\end{array}$ & $\begin{array}{l}\text { 9. Os participantes usaram } \\
\text { evidências para apoiar e } \\
\text { desafiar as ideias ou dar sentido } \\
\text { ao fenômeno sob investigação. }\end{array}$ & $\begin{array}{l}\text { 16. Os participantes respeitam } \\
\text { o que o outro tem a dizer. }\end{array}$ \\
\hline $\begin{array}{c}\text { 3. Os participantes } \\
\text { modificaram sua conclusão ou } \\
\text { explicação quando notaram } \\
\text { uma inconsistência ou } \\
\text { descobriram informações } \\
\text { anômalas. } \\
\end{array}$ & $\begin{array}{c}\text { 10. Os participantes } \\
\text { examinaram a relevância, a } \\
\text { coerência e a suficiência das } \\
\text { provas. }\end{array}$ & $\begin{array}{l}\text { 17. Os participantes discutiram } \\
\text { uma ideia quando ela foi } \\
\text { introduzida na conversa. }\end{array}$ \\
\hline $\begin{array}{l}\text { 4. Os participantes estavam } \\
\text { céticos sobre ideias e } \\
\text { informações. }\end{array}$ & $\begin{array}{l}\text { 11. Os participantes avaliaram } \\
\text { a forma como os dados } \\
\text { disponíveis foram interpretados } \\
\text { ou o método usado para coletar } \\
\text { os dados. }\end{array}$ & $\begin{array}{l}\text { 18. Os participantes } \\
\text { encorajaram ou convidam } \\
\text { outros para compartilhar ou } \\
\text { criticar ideias. }\end{array}$ \\
\hline $\begin{array}{l}\text { 5. Os participantes forneceram } \\
\text { razões enquanto apoiavam ou } \\
\text { contestavam uma ideia. }\end{array}$ & $\begin{array}{l}\text { 12. Os participantes usaram as } \\
\text { teorias científicas, leis ou } \\
\text { modelos para apoiar e desafiar } \\
\text { ideias ou para ajudar a atribuir } \\
\text { sentido ao fenômeno sob } \\
\text { investigação. } \\
\end{array}$ & $\begin{array}{l}\text { 19. Os participantes reafirmam } \\
\text { ou sumarizam comentários e } \\
\text { perguntavam uns aos outros } \\
\text { para esclarecer ou detalhar seus } \\
\text { comentários. }\end{array}$ \\
\hline $\begin{array}{l}\text { 6. Os participantes basearam as } \\
\text { suas decisões ou ideias sobre } \\
\text { estratégias de raciocínio } \\
\text { inadequadas. }\end{array}$ & $\begin{array}{l}\text { 13. Os participantes fizeram } \\
\text { distinções e conexões entre } \\
\text { inferências e observações } \\
\text { explícitas por outros. }\end{array}$ & \\
\hline $\begin{array}{l}\text { 7. Os participantes tentaram } \\
\text { avaliar os méritos de cada } \\
\text { explicação ou alegação } \\
\text { alternativa de forma } \\
\text { sistemática. }\end{array}$ & $\begin{array}{l}\text { 14. Os participantes usam a } \\
\text { linguagem científica para } \\
\text { comunicar ideias. }\end{array}$ & \\
\hline
\end{tabular}

Quadro 1: Avaliação da Argumentação Científica dentro da Sala de Aula (AACS)

Sampson et. al. (2012) destacam ainda que nos últimos anos muitos estudos focaram na estrutura geral dos argumentos, suas justificações, a validade de suas conclusões e sua adequação epistemológica. Por outro lado, existem poucas propostas para investigar os processos sociais e as práticas envolvidos na produção dos argumentos, sendo o protocolo de observação AACS útil para observar todos esses aspectos da argumentação científica.

Dentro dos três aspectos da argumentação destacados na AASC, encontramos alguns itens em que as características da argumentação matemática que discutimos no capítulo 1 e sua interface com a física podem ser mais bem analisadas e explicitadas: 
- Aspectos conceituais e cognitivos: O item 2 possibilita observar se os estudantes usam a matemática nas conclusões ou como garantia para as mesmas, situação em que a abdução pode ficar evidente. No item 3 o tratamento da anomalia pode envolver tanto a abdução quanto o uso da matemática, ao formular uma hipótese que explique uma observação surpreendente ou anômala. Com o item 5 pode-se ficar atento ao papel da matemática como suporte às alegações, e ainda, novamente a abdução pode ocorrer já que os dados podem não ser explícitos ${ }^{10}$. O item 6 permite verificar se o tipo de abdução foi correta, ou seja, se os estudantes (a) saltam para generalizações apressadas, (b) atribuem causalidade para eventos aleatórios, (c) insistem que a correlação é uma evidência de causalidade e (d) apresentam um viés de confirmação.

- Aspectos epistêmicos: O item 9 destaca a importância de se considerar dados quantitativos/matemáticos para justificar as alegações e conclusões. $O$ item 10 traz a relevância do tipo de prova usada na ciência e sua suficiência, que envolve a matemática, isto é, quais provas ou quantos dados são necessários para dar suporte a uma alegação. Nos itens 11 e 12 destaca-se a importância da linguagem matemática para a interpretação de um fenômeno e construção de uma prova, buscando apoio nas leis ou modelos. A escolha desses últimos pode ser por um processo abdutivo. Os itens 13 e 14 destacam o uso de dados quantitativos e da linguagem matemática na elaboração de um argumento sólido.

- Aspectos sociais: O item 15 diz respeito à concordância sobre qual parte da matemática pode ser usada para interpretar um fenômeno.

O quadro a seguir resume as ferramentas apresentadas até este ponto:

\footnotetext{
${ }^{10}$ Por exemplo, quando os estudantes observam um fenômeno novo ou surpreendente em um experimento e não tem dados que expliquem o que se apresenta diante deles.
} 


\begin{tabular}{|c|c|}
\hline Autor(es) & Ferramentas para análise da argumentação \\
\hline $\begin{array}{l}\text { Vieira e } \\
\text { Nascimento } \\
(2008 \text { e 2009) } \\
\text { e Nascimento e } \\
\text { Vieira (2009) }\end{array}$ & Demarcação da argumentação: contraposição e justificação de ideias e TAP. \\
\hline $\begin{array}{l}\text { Sasseron } \\
(2008)\end{array}$ & $\begin{array}{c}\text { Estrutura do argumento: TAP e Argumento hipotético-dedutivo. Qualidade do } \\
\text { argumento: níveis conforme o número de justificações e refutações. }\end{array}$ \\
\hline $\begin{array}{l}\text { Sasseron e } \\
\text { Carvalho } \\
(2011 b)\end{array}$ & $\begin{array}{c}\text { Eixos estruturantes de AC e Indicadores de AC (levantamento e teste de hipóteses; } \\
\text { seriação, classificação e organização de informações; explicação; justificativa, } \\
\text { previsão, raciocínio lógico e proporcional). Ciclo argumentativo: cuidado com os } \\
\text { dados existentes, definição de variáveis relevantes ao problema, explicação. Relação } \\
\text { entre o TAP e os indicadores de AC: conhecimentos básicos e classificação e } \\
\text { organização de informações; dados e hipóteses; conclusões e explicação; garantias e } \\
\text { justificativas; qualificadores modais e previsão. }\end{array}$ \\
\hline $\begin{array}{l}\text { Jiménez- } \\
\text { Aleixandre et. } \\
\text { al. (2000) }\end{array}$ & $\begin{array}{l}\text { Momentos de Fazer escola ou Fazer e falar ciência, que são delimitados pelo TAP e } \\
\text { incluem: os estudantes perguntando, informando-se individualmente ou em grupo, } \\
\text { discutindo com seus colegas ou em pequenos grupos e escrevendo depois de } \\
\text { discussões orais. Operações epistemológicas: dedução; indução; causalidade; } \\
\text { definição; o uso de analogias, exemplos, atributos e autoridade; consistência com } \\
\text { outros conhecimentos, com a experiência, com o compromisso com a consistência e } \\
\text { com a metafísica e plausibilidade. }\end{array}$ \\
\hline $\begin{array}{l}\text { Jiménez- } \\
\text { Aleixandre e } \\
\text { Bustamante } \\
\text { (2003) }\end{array}$ & $\begin{array}{c}\text { Uso do TAP e das Operações epistêmicas: “[...] procedimentos explicativos, } \\
\text { definições, classificações, relações causais, apelo a analogias ou comparações, ou } \\
\text { construção de dados” (p.366). }\end{array}$ \\
\hline $\begin{array}{l}\text { Sampson et. al. } \\
\qquad(2012)\end{array}$ & $\begin{array}{l}\text { AACS: avaliar 1) os principais processos cognitivos e estruturas conceituais da } \\
\text { ciência; 2) os conhecimentos e a utilização do quadro epistêmico da ciência para } \\
\text { desenvolver e avaliar conclusões; } 3 \text { ) a participação social na argumentação científica } \\
\text { compreendendo "as formas como o conhecimento é comunicado, representado, } \\
\text { argumentado e debatido dentro da comunidade científica" (p. 239). }\end{array}$ \\
\hline
\end{tabular}

Quadro 2: Ferramentas para análise dos processos argumentativos em sala de aula

Ao analisar o quadro acima é notável a influência do TAP nas pesquisas como forma de delimitar situações argumentativas, nas quais há justificação do conhecimento, explicitando o raciocínio dos estudantes, e, por outro lado, a necessidade do uso de outras ferramentas para estudar as características campo-dependentes da argumentação, representadas pelas operações epistemológicas e epistêmicas e os indicadores de alfabetização científica. Dessa forma, ao construir um instrumento de análise para o nosso objeto de estudo é importante sistematizar o que os pesquisadores definem como argumentação científica ou campo-dependente na nomenclatura de Toulmin (2006).

Nesse sentido, ao comparar os referenciais do quadro 2, observamos que algumas categorias são próximas senão similares, ou seja, raciocínio lógico $e$ proporcional e causalidade; procedimentos explicativos e explicação; justificativa e uso de definição, apelo à analogia ou comparações, exemplos, atributos, consistência com outros conhecimentos (incluindo a experiência e a metafísica) e plausibilidade. Notamos também que as categorias da AACS estão 'diluídas' nesses itens, porém elas 
são muito abertas, por isso, optamos por considerar as classificações dos demais referenciais para acompanhar as especificidades da argumentação matemática.

Com essa análise destacamos os seguintes componentes do processo de argumentação envolvendo elementos campo-dependentes no contexto da ciência: levantamento e teste de hipóteses; seriação, classificação e organização de informações; explicação; justificativa, previsão, dedução; indução, raciocínio lógico e proporcional. Ressaltamos que a categoria justificativa engloba uso de definição, apelo à analogia ou comparações, exemplos, atributos, consistência com outros conhecimentos (incluindo a experiência e a metafísica) e plausibilidade. Além disso, temos por hipótese que diferentes componentes ocorrerão em sala de aula em momentos distintos do ciclo argumentativo, que é desencadeado a partir de atividades investigativas.

Para uma caracterização mais precisa da argumentação abrangendo os seus aspectos matemáticos é necessário incluir os conteúdos discutidos no capítulo 1. Dessa maneira, nossa outra hipótese é que os tipos de abdução devem aparecer com o processo de levantamento e teste de hipóteses, e ainda, que as refutações são importantes no estabelecimento das condições de consistência e a plausibilidade do conteúdo científico, já que elas indicam os limites de uma alegação. Assim, esses elementos encontram-se no interior do processo de justificativa.

A seguir discutimos alguns trabalhos sobre argumentação no ensino de ciências que fazem sínteses sobre as pesquisas nessa área e que contribuem com importantes elementos para o nosso objeto de pesquisa, possibilitando uma discussão mais ampla sobre os elementos e a qualidade dos argumentos.

\subsubsection{Perspectivas críticas da argumentação no ensino de ciências}

Anteriormente discutimos diversos referenciais e maneiras para análise da argumentação, muitos deles partem do TAP e outros buscam englobar elementos que esse último não dá conta, tal como as operações epistemológicas, que envolvem as características campo-dependentes do argumento. Além disso, existe um esforço dos pesquisadores em considerar os critérios de validação do conhecimento científico, o que envolve uma consideração da sua qualidade. Neste tópico aprofundamos essas 
discussões, a partir da sistematização de trabalhos que fazem uma revisão crítica desses referenciais (Aberdein, 2005; Erduran, 2007; MacDonald e Kelly, 2012; Sampson e Clark, 2006; Sandoval e Millwood, 2007).

Aberdein (2005) reconhece as críticas ao TAP, que não possibilita acompanhar o processo de construção do argumento e que a reconstrução do padrão pode distorcer o argumento original - "o layout é perniciosamente ambíguo, criando diferentes e incompatíveis reconstruções possíveis" (p.289).

Dentro desse panorama, um importante artigo é o de Sandoval e Millwood (2007) que destaca que a característica epistemológica da argumentação em ciências emerge no processo de justificação das alegações científicas - o principal objetivo do ensino que visa à argumentação. Isto remete às seguintes questões, que dependem de conhecimentos epistemológicos para suas respostas:

O que conta como alegação? O que conta como prova? Como você decide que tipo de evidência apoia ou refuta uma alegação particular? Como alegações individuais são organizadas para produzir um argumento coerente? Que tipos de coordenação de alegações e evidência constituem argumento persuasivo? (SANDOVAL e MILLWOOD, 2007, p. 72).

Nesse sentido, destacam os autores, há várias pesquisas que analisam as argumentações orais dos estudantes em ambientes investigativos ou de resolução de problemas. Os principais movimentos epistêmicos desencadeados nos alunos são: uso de alegações sem apresentar justificativas explícitas; alegações costumam ser justificadas somente quando desafiadas; geralmente alegações são oferecidas sem relação com os outros elementos do argumento em desenvolvimento; uso de várias formas de garantias, incluindo evidências experimentais e teóricas.

$\mathrm{Na}$ avaliação dos argumentos científicos escritos, que são muito parecidos com os orais, os pesquisadores verificaram o fracasso dos estudantes, porém essa prática auxilia no entendimento de ideias importantes da ciência.

[...] a pesquisa sobre as práticas de argumentação dos alunos sugere a complexidade de coordenar adequadamente afirmações causais com evidência. É claro que, a questão é o que exatamente significa coordenar alegações e as evidências adequadamente. Por exemplo, dentro de contextos profissionais de ciências as alegações que precisam ser explicitamente garantidas são apenas aquelas que ainda não foram aceitas. Assim, o fracasso dos alunos para justificar afirmações particulares não é inerentemente "não científico", mas pode simplesmente refletir a crença de que essas alegações já são aceitas. As análises da argumentação oral, mencionadas acima, mostram que os estudantes, de fato, proporcionam garantias quando as alegações são contestadas, como os próprios cientistas fazem. Questões de coordenação de alegação e evidências em argumentos escritos, por outro lado, pode indicar que os alunos não veem a tarefa retórica de um argumento científico como uma persuasão. A forte ligação de evidências e alegações de que nós tomamos como certa em argumentos científicos reflete um esforço retórico 
para convencer os leitores da aceitabilidade de um argumento. Tais estratégias retóricas não são simplesmente sociais, mas podem ser necessárias para fazer novas ideias compreensíveis (KITCHER, 1991, apud SANDOVAL e MILLWOOD, op. cit., p.73).

Os autores propõem as práticas epistemológicas como uma forma dos estudantes desenvolverem ideias epistemológicas altamente contextualizadas, a partir de experiências práticas para entender e explicar o mundo que eles vivem. Isto é desencadeado por meio da explicação de novas situações.

Em uma abrangente revisão de literatura, Erduran (2007) mostra que o principal desafio nos estudos que envolvem argumentação está na metodologia de pesquisa e que várias questões emergem ao distinguir dados de garantias:

\footnotetext{
Podemos considerar afirmações teóricas como dados? Se uma garantia não está explicitamente declarada, podemos assumi-la como parte do argumento?... O que conta como argumento na fala de uma criança? Qual é a unidade de análise do argumento e da argumentação nas conversas? Quais critérios orientam a seleção e aplicação de ferramentas de codificação? O que justifica a escolha de uma metodologia em favor de outra? O que uma metodologia específica nos possibilita fazer e como isso ocorre? (ERDURAN, op. cit., p. 47).
}

Seu objetivo é garantir validade às ferramentas metodológicas de análise do argumento, explicitando sua natureza e função em oposição a uma visão positivista desses conhecimentos. O foco deste trabalho está no modelo de Toulmin e a geração de categorias, fundamentadas em perspectivas teóricas e empíricas, a partir dos dados e dos desafios que se apresentam nessa abordagem.

Logo, para que se possam estudar tais situações, as questões metodológicas da argumentação necessitam adaptar as perspectivas teóricas para uso metodológico e para a geração de ferramentas analíticas.

Como critério para definir e delimitar as fronteiras de análise da argumentação na sala de aula, esses estudos estão focados na análise de evidências e justificações, nas práticas e critérios epistêmicos, na argumentação e a natureza dos argumentos e na participação em discussões.

Neste ponto, Erduran (op. cit.) apresenta algumas tendências para a análise da argumentação, que repousa mais sobre a estrutura qualitativa do argumento do que sobre sua quantificação, que possibilitaria, por exemplo, uma abordagem metodológica que vise ao entendimento de correlações e associações. Destacam-se ainda as formas de codificar os argumentos, principalmente em como definir a unidade de análise tanto na escrita quanto no verbal. Ela sublinha o TAP para definir a estrutura argumento diante 
dos desafios que se apresentam, porém, é difícil precisar o que conta como cada parte desse modelo e como enquadrá-lo em argumentos longos.

A autora ainda enfatiza algumas das contribuições do uso da metodologia desenvolvida por Stephen Toulmin, apesar de suas limitações, para o conhecimento da educação em ciência sobre os estudos do tipo "especialistas-novatos" e de resolução de problemas, o raciocínio científico e as representações teóricas e estruturais.

Erduran (op. cit.) explica que a dificuldade de aplicar o modelo de Toulmin deve-se mais ao fato de determinar os limites de codificação que geram ferramentas de análise, do que uma característica limitada do modelo. Ela também ressalta os desafios no estudo da argumentação na sala de aula:

- Simon et. al. (2006, apud ERDURAN, 2007) construíram uma preliminar tipologia das estratégias pedagógicas no ensino da argumentação, contudo, é necessário elaborar novas ferramentas para analisar o ensino, com o intuito de gerar um modelo pedagógico mais efetivo;

- Estender a análise da argumentação do contexto verbal para o multimodal;

- Faltam na literatura estudos que revelem os aspectos complexos do ambiente de sala de aula incluindo as estruturas e os processos sociológicos, políticos e psicológicos que mediam a argumentação na ciência escolar;

- Investigar a interdisciplinaridade usando abordagens científicas.

Similarmente à pesquisa de Erduran (2007), Sampson e Clark (2006) fazem uma revisão dos principais quadros teóricos para análise dos argumentos retóricos no ensino de ciências visando esclarecer a lógica e as premissas desse campo, suas limitações e possibilidades e apontar novos caminhos.

Segundo os autores, a argumentação surge no processo de investigação científica, na qual se reduz o mundo à ordem, que toma a forma de explicações testadas e desenvolvidas em um processo de observação e de identificação de padrões em dados. Procura-se estabelecer a aceitabilidade da explicação coordenando evidências afirmativas ou contraditórias sobre a observação de um fenômeno ou uma afirmação descritiva ou exploratória. Nesse processo, deve-se ficar atento aos critérios epistemológicos que definem o que conta ou não como garantia, por exemplo:

(a) a necessidade de fornecer apoio racional ou de evidências para afirmações de conhecimento e propor testes para as mesmas (Hogan e Maglienti, 2001), (b) a necessidade de coerência entre quadros teóricos e observações de fenômenos (Passmore e Stewart, 2002), (c) estabelecer a credibilidade das provas (Driver et al., 2000), (d) parcimônia (Sandoval e Reiser, 2004), e (e) a importância de basear os argumentos em um raciocínio que é logicamente 
válido (Zeidler, 1997). Assim, a fim de gerar um argumento científico, o indivíduo deve aprender os tipos de alegações que os cientistas fazem, como promovê-las, que tipos de provas são necessárias para justificar um argumento, e como que as provas podem ser recolhidas e interpretadas por dados padrões da comunidade (SAMPSON e CLARK, op. cit., p.655).

Nesse contexto, são propostos vários quadros teóricos para analisar como os alunos propõem seus argumentos retóricos, como é o raciocínio nesse processo, se ele diverge dos cientistas e se eles conseguem desenvolver a habilidade argumentativa proposta por meio de uma situação de ensino.

O principal referencial usado pelos pesquisadores de ensino de ciências é o de Stephen Toulmin, que mostrou como e quando os estudantes propõem garantias para alegações e sobre o que isso se fundamenta, tanto em linguagem oral quanto escrita. Por outro lado, essa ferramenta não permite observar a qualidade do argumento em termos de como ou se as ideias conceituais dos alunos influenciam na relação que eles desenvolvem entre teoria e evidência na construção de um argumento. Além disso, ela não possibilita uma análise das características campo-dependentes dos elementos da estrutura do argumento, por exemplo, o que conta como dado, garantia, conclusão ou conhecimento básico. Assim, não permitindo saber o quanto os argumentos dos discentes aderem aos critérios compartilhados pela comunidade científica para avaliar a qualidade dos mesmos e, portanto, verificar o raciocínio usado na construção do argumento. Os autores ressaltam que esses critérios dependem dos compromissos lógicos e epistemológicos específicos da ciência, logo, são necessárias outras ferramentas para estudar essas características.

Dessa forma, Sampson e Clark (op. cit.) procuram delinear características gerais da argumentação científica, por exemplo, as teorias são comunicadas e avaliadas a partir de evidências experimentais, para assim partir para as especificidades de cada disciplina. Os autores enfatizam que pouco foi feito nessa direção e apontam cinco critérios para avaliar argumentos científicos de alta qualidade:

1 - Examinar a natureza e a qualidade da alegação de conhecimento: alegações são conclusões exploratórias ou referenciais descritivos, os quais os cientistas tentam generalizar. Assim, a ciência trata de criar e testar referenciais e teorias, o que destaca a importância de analisar o tipo de alegação produzida por estudantes no processo de investigação, verificando a qualidade desse argumento em relação ao conhecimento científico, revelando seus entendimentos sobre como coordenar afirmações com as evidências disponíveis. 
2 - Examinar como (ou se) a alegação é justificada: sendo a evidência empírica importante para avaliar a validade das afirmações, deve-se ponderar o seu papel nos argumentos dos estudantes, além dos tipos de evidência que justificam um argumento e como a evidência é interpretada em termos dos referenciais aceitos pela comunidade. "Os tipos de razões e evidências utilizados pelos alunos e como eles as usam podem nos dizer muito sobre o que eles consideram boas explicações ou conhecimento justificado" (SAMPSON e CLARK, op. cit., p. 659-660).

3 - Examinar se a alegação refere-se a todas as evidências disponíveis: os cientistas constroem argumentos para as conjecturas que melhor explicam um fenômeno, amparados pelas evidências disponíveis ou obtendo novas, quando não há evidências suficientes. Essa coordenação entre alegações e evidências deve ser considerada em um instrumento que analise a qualidade dos argumentos científicos.

4 - Examinar como (ou se) o argumento procura desconsiderar alternativas: explicações alternativas são comuns na ciência e os argumentos em favor de uma delas podem não ser totalmente convincentes em virtude das evidências disponíveis. Dessa forma, a ferramenta de análise deve permitir verificar como os estudantes avaliam a aceitabilidade e a utilidade de argumentos alternativos. Pode-se usar os seguintes critérios: “(a) a capacidade da alegação dar conta de todas as observações relativas ao fenômeno, (b) a sua utilidade na previsão do comportamento do fenômeno, e (c) a consistência da alegação com outro conhecimento aceito sobre como o mundo funciona" (DRIVER et al, 2000; PASSMORE e STEWART, 2002 apud SAMPSON e CLARK, op. cit., p.660).

5 - Examinar como as referências epistemológicas são usadas para coordenar alegações e evidências: além de justificar as ideias com evidências, os alunos devem avaliar se suas evidências foram coletadas e interpretadas pelas normas da comunidade científica.

De forma similar, MacDonald e Kelly (2012) fazem uma análise crítica dos trabalhos sobre argumentação. Eles afirmam que a partir da década de 80, aumenta o foco em atividades de ensino de ciências que refletem as práticas da comunidade científica, devido à emergência das teorias de aprendizagem focadas nas comunidades e suas práticas. Uma das formas de aculturar ${ }^{11}$ os alunos é por meio de atividades de

\footnotetext{
${ }^{11}$ Não concordamos com o termo aculturação, preferimos enculturação, o qual é sinônimo de uma aprendizagem na qual os estudantes ampliam sua cultura e visão de mundo, e ainda, são inseridos nas práticas da cultura científica (DRIVER et. al., 1999; CAPECCHI, 2004a).
} 
investigação, que contemplam buscar evidências, argumentar, comunicar as ideias científicas e a engajá-los em suas questões, o que destaca a importância da natureza da ciência no processo de instrução científica.

Eles ressaltam que o foco somente no discurso argumentativo dos estudantes, ignora características importantes das práticas da comunidade científica que devem ser aprendidas, ou seja, limita o desenvolvimento da compreensão das formas que os cientistas trabalham em sua comunidade e a construção de um apoio ao desenvolvimento de normas e práticas produtivas em comunidades de aprendizagem de ciência:

\begin{abstract}
A investigação nesta área mostra sinais de definições cada vez mais específicas e calcificadas de argumentação e em como o discurso em aulas de ciências é analisado. Há tanto a justiça social quanto preocupações de equidade em torno de um foco pedagógico estreito, sobre um tipo de discurso do estudante e significativas limitações analíticas em termos da compreensão da qualidade e produtividade do discurso dos alunos em salas de aula de ciência (MACDONALD e KELLY, op. cit., p.266).
\end{abstract}

Por meio de exemplos de situações em sala de aula, os autores mostram as limitações da análise dos argumentos em episódios com baixa qualidade do argumento e sua estrutura, porém com grande potencialidade em termos do "fazer científico". Ainda, é explícita a limitação da análise somente em termos da linguagem oral, destacando-se a necessidade de se considerar as conexões das diferentes representações - ponto similar ao destacado por Erduran (2007).

Além disso, destacam os autores, a linguagem da sala de aula é afiliada a um discurso pertencente a um grupo social, imergido em uma cultura, com suas formas de falar e agir, nas quais expectativas são construídas, contestadas e refinadas. Logo, o modo como a evidência respalda um argumento depende do grupo a qual ele se integra. Nesse contexto, há várias formas de discurso e maneiras como a linguagem se relaciona ao trabalho científico, que variam conforme o auditório (avaliador de um periódico, os colegas de laboratório etc.), os propósitos (conferência, defesa pública dos dados etc.) e os locais (apresentação de seminário, aula etc.). É preciso atentar a esse fato já que:

[...] enquanto a reforma educacional tem urgido para a emulação da prática científica em ambientes educacionais, não houve uma análise cuidadosa do intervalo e da tipicidade de tais práticas. Muitas vezes, a reforma educacional é baseada em um conjunto de hipóteses sobre a prática científica, com pouca evidência empírica para fundamentar os objetivos normativos assumidos. $\mathrm{O}$ padrão de pensamento da ciência como método científico e do seu ensino como forma final do processo é um exemplo que foi posteriormente problematizado pelos estudos sociais da ciência. A argumentação fornece um exemplo de como trazer práticas científicas para a educação oferece potencialidades de novas formas de aprendizagem, mas tais práticas devem ser consideradas em um contexto mais amplo de discursos e práticas para que 
elas não se tornem outra caracterização estereotipada e praticamente vazia de práticas científicas (MACDONALD e KELLY, op. cit., p.272).

Dentro desse contexto, há três premissas sobre os processos argumentativos como forma de avaliar as habilidades de engajar nas práticas científicas: (1) ela oferece oportunidades para tal situação, incluindo falar ciência; (2) possibilita a aprendizagem conceitual, visto que acarreta criar sentidos e um entendimento profundo dos conceitos; e, por fim, (3) propicia um entendimento da natureza da ciência.

MacDonald e Kelly (2012) discutem ainda as limitações dessas afirmações. Eles assumem a argumentação como forma de se iniciar nas práticas científicas, mas além da variedade de discursos na ciência, há "outras formas de comunicação, de construir afiliação, e de interagir nas quais declarações explícitas de conclusões apoiadas por evidências não fazem parte do discurso" (p.273). Além do mais, é difícil definir quais são as práticas da ciência e muitas vezes os ambientes de sala de aula não se equivalem ao contexto científico, e o professor também não é um cientista real, logo, a aproximação entre ciência e ensino é limitada devido aos diferentes propósitos e restrições contextuais de cada uma delas. Por exemplo, aprender ciências envolve formas de falar, escrever e ouvir que não se equiparam às usadas nos laboratórios e nem sempre os estudantes se envolvem em discursos argumentativos, mas mesmo nesses casos pode existir valor pedagógico.

Sobre a aprendizagem conceitual, eles destacam que é preciso extrapolar as formas canônicas de apresentar os conceitos, incluindo as dimensões conceituais, epistêmicas e sociais da teoria. Também é importante conhecer como as provas são validadas na ciência e o que conta como um bom argumento, assim, a argumentação constitui uma parte do suporte à aprendizagem, mas não é única.

Por último, MacDonald e Kelly (op. cit.) discutem que as práticas argumentativas, mesmo sendo importantes, são mais um dos discursos usados na ciência e é preciso cuidado para que não se linearize as propostas de ensino-aprendizagem baseadas nesses conhecimentos. Os autores destacam três pontos preocupantes:

1. A argumentação carrega o potencial para que os estudantes ampliem seus modos de falar e ouvir, porém pode limitar a participação dos estudantes que não estão mais próximos dos discursos científicos e privilegiar os que estão.

2. Pelas diferenças de gênero, já que a busca por evidências pode conduzir a uma competição - situação na qual os estudantes, em particular uma parcela do sexo feminino, podem achar menos interessante do que a ciência em si. 
3. As práticas argumentativas nas escolas foram planejadas em torno das maneiras pré-determinadas da educação científica, deixando de lado, por exemplo, o raciocínio espontâneo ou outro tipo na explicação de evidências, podendo haver um preconceito implícito.

A seguir temos um quadro-resumo das ferramentas e críticas apresentadas nesse tópico:

\begin{tabular}{|c|c|}
\hline Autor(es) & Argumentação: Ferramentas e críticas \\
\hline $\begin{array}{l}\text { Sandoval e } \\
\text { Milwood } \\
(2007)\end{array}$ & $\begin{array}{c}\text { Justificação das alegações científicas } \rightarrow \text { característica epistemológica da } \\
\text { argumentação. Movimentos epistêmicos para justificar alegações: uso de alegações } \\
\text { sem apresentar justificativas explícitas; alegações justificadas somente quando } \\
\text { desafiadas; alegações oferecidas sem relação com os outros elementos do argumento } \\
\text { em desenvolvimento e uso de várias formas de garantias, incluindo evidências } \\
\text { experimentais e teóricas. }\end{array}$ \\
\hline Erduran (2007) & $\begin{array}{l}\text { Metodologias: Evidências e Justificações (TAP); Práticas e critérios epistêmicos; } \\
\text { Argumentação e a natureza do argumento; Participação em discussões. } \\
\text { Potencialidades do TAP: explicita o raciocínio; estudo de alunos em situações de } \\
\text { resolução de problemas e na imersão na cultura científica; facilita representações } \\
\text { teóricas e experimentais. Limites metodológicos: criar situações de ensino que levem } \\
\text { a argumentar; análise multimodal da argumentação; aspectos complexos do ensino que } \\
\text { interferem na argumentação e estudo da interdisciplinaridade com uma abordagem } \\
\text { científica. }\end{array}$ \\
\hline $\begin{array}{c}\text { Sampson e } \\
\text { Clark (2006) }\end{array}$ & $\begin{array}{l}\text { Limites do TAP: observar a qualidade do argumento e suas características campo } \\
\text { dependentes (na ciência, o que conta como dado, garantia, conhecimento básico ou } \\
\text { conclusão depende dos critérios lógicos e epistemológicos da ciência). Critérios para } \\
\text { avaliar argumentos de alta qualidade: examinar a natureza e a qualidade da } \\
\text { alegação de conhecimento; examinar como (ou se) a alegação é justificada; examinar } \\
\text { se a alegação refere-se a todas as evidências disponíveis; examinar como (ou se) o } \\
\text { argumento procura desconsiderar alternativas; examinar como as referências } \\
\text { epistemológicas são usadas para coordenar alegações e evidências. }\end{array}$ \\
\hline $\begin{array}{l}\text { MacDonald e } \\
\text { Kelly (2012) }\end{array}$ & $\begin{array}{l}\text { Argumentação não é suficiente para analisar o discurso, que depende do grupo em que } \\
\text { ela ocorre. Existem outros discursos na ciência e no seu ensino. A analogia entre } \\
\text { ciência e ensino é limitada. Aprendizagem conceitual deve incluir as dimensões sociais } \\
\text { e epistêmicas da teoria e levar em conta como as provas são validadas. }\end{array}$ \\
\hline
\end{tabular}

Os autores acima destacam as dificuldades metodológicas de se analisar a argumentação em sala de aula. Grande parte delas compreende dificuldades inerentes do uso do TAP, que foi idealizado como uma estrutura geral para análise de um argumento logicamente válido e que não foi concebido para o estudo do argumento em construção. Por outro lado, encontramo-nos no contexto do ensino de ciências, no qual as características da ciência são fundamentais na construção do discurso argumentativo, portanto, os autores procuram delimitar quais são esses conhecimentos a serem incluídos nesse processo. Emerge desse panorama, a necessidade de coordenar alegações e evidências usando as referências epistemológicas da ciência tanto no ensino como na sua análise, situação na qual pode ser útil a classificação desenvolvida no final do tópico anterior. 
Nesse sentido há vários pontos comuns entre os autores que permitem avaliar a qualidade de um argumento no contexto do ensino de ciências envolvendo a matemática e que podemos considerar em nosso trabalho.

Essas similaridades estão explícitas nos trabalhos de Sandoval e Milwood (2007) e Sampson e Clark (2006) e também refletem a forma como a aprendizagem conceitual deve considerar como as provas são validadas (MACDONALD e KELLY, 2012), e, ainda, podem ser usadas para julgar a qualidade da argumentação na sala de aula, extrapolando o número de justificativas para indicar essa qualidade apresentado nos artigos de Jiménez-Aleixandre e Bustamante (2003) e Sasseron (2008). Abaixo apresentamos uma proposta de categorias baseadas nesses trabalhos:

\begin{tabular}{|c|c|c|}
\hline $\begin{array}{c}\text { Categorias de análise da } \\
\text { qualidade da } \\
\text { argumentação }\end{array}$ & Sandoval e Milwood (2007) & Sampson e Clark (2006) \\
\hline $\begin{array}{c}\text { coordenação entre alegações } \\
\text { e evidências }\end{array}$ & $\begin{array}{c}\text { Uso de alegações sem apresentar } \\
\text { justificativas explícitas, alegações } \\
\text { justificadas somente quando } \\
\text { desafiadas, alegações oferecidas } \\
\text { sem relação com os outros } \\
\text { elementos do argumento em } \\
\text { desenvolvimento. }\end{array}$ & $\begin{array}{c}\text { Examinar a natureza e a qualidade } \\
\text { da alegação de conhecimento; } \\
\text { examinar como (ou se) a alegação } \\
\text { é justificada; examinar se a } \\
\text { alegação refere-se a todas as } \\
\text { evidências disponíveis; examinar } \\
\text { como (ou se) o argumento procura } \\
\text { desconsiderar alternativas. }\end{array}$ \\
\hline $\begin{array}{c}\text { Ex - Conteúdos para } \\
\text { coordenação entre alegações } \\
\text { e evidências }\end{array}$ & $\begin{array}{c}\text { Uso de várias formas de garantias, } \\
\text { incluindo evidências experimentais } \\
\text { e teóricas. }\end{array}$ & $\begin{array}{c}\text { Examo as referências } \\
\text { epistemológicas são usadas para } \\
\text { coordenar alegações e evidências. }\end{array}$ \\
\hline
\end{tabular}

Quadro 4: Elementos para análise da qualidade da argumentação

Na categoria 1, reunimos as práticas que envolvem as formas de ocorrência da argumentação científica, ou seja, ela permite avaliar como as alegações são respaldadas por justificativas. Um argumento coerente e de qualidade, principalmente no contexto da ciência, deve apresentar justificativas e relacionar todas as evidências disponíveis, além de explicitar o seus limites.

Dentro da categoria 2, agrupamos as práticas de justificação que remetem aos conteúdos da argumentação científica, envolvendo os critérios campo-dependentes dessa prática que foram destacados no final do tópico anterior: levantamento e teste de hipóteses e abdução; seriação, classificação e organização de informações; explicação; justificativa (uso de definição, apelo à analogia ou comparações, exemplos, atributos, consistência com outros conhecimentos - incluindo a experiência e a metafísica - e plausibilidade), previsão, dedução; indução, raciocínio lógico $e$ proporcional.

Destacamos ainda a necessidade de se refletir sobre as linguagens por meio do qual se apresentam os conhecimentos científicos tanto na categoria 1 (forma para 
coordenação entre alegações e evidências), quanto na categoria 2 (conteúdos para coordenação entre alegações e evidências), ou seja, durante a argumentação científica na sala de aula há necessidade de se expressar principalmente por meio das linguagens ou modos de comunicação - verbal, escrita, gestual, visual (desenhos, esquemas e tabela), gráfica e algébrica.

Isso remete aos limites metodológicos apresentados por Erduran (2007) e que tem relação com os objetivos da presente pesquisa: estender a análise da argumentação do contexto verbal para o multimodal. Esse tipo de análise da argumentação parte do pressuposto de que o discurso científico no contexto de pesquisa e na sala de aula é constituído a partir de várias formas de representações simbólicas ou linguagens (LEMKE, 1998a), e a construção do argumento científico só será completa ao considerá-las (ERDURAN, op. cit.). Dessa forma, discutiremos no próximo tópico um instrumento (BELLUCCO, 2012a) que permite observar os diferentes modos de comunicação, na construção dos elementos do TAP e, no capítulo seguinte, sistematizaremos os instrumentos apresentados em uma ferramenta de análise da argumentação matemática nas aulas de física.

É importante enfatizar ainda que os diferentes trabalhos mostram que as atividades investigativas propiciam situações argumentativas. Isso é essencial, já que analisaremos situações de ensino-aprendizagem que favorecem os estudantes a argumentarem. Em outras palavras, não adianta construir um instrumento de análise com as características propostas, se as condições de ensino estudadas não foram planejadas para que os alunos apresentem alegações, justificando-as ou refutando-as.

Também somos favoráveis às críticas de MacDonald e Kelly (2012) aos trabalhos que envolvem a argumentação - levamos em conta a necessidade da inclusão das dimensões conceituais, epistêmicas e sociais do conteúdo no delineamento das atividades de ensino que analisaremos. Essas dimensões podem inclusive serem discutidas a partir das categorias propostas no quadro 4 acima, que envolvem a forma para coordenar alegações e evidências (dimensão social) e os conteúdos para coordenar alegações e evidências (dimensão epistêmica). Quanto à questão dos outros tipos de discurso na ciência e no seu ensino destacados por esses autores, consideramos um ponto relevante. Por outro lado, precisamos optar por qual direcionamento daremos a este trabalho, ou seja, dentro da proposta delineada até aqui, a análise dos outros tipos de discurso desvirtuaria o foco social típico da argumentação que pretendemos estudar, 
ao observar o conteúdo matemático demandado pelos estudantes, no processo de construção dos conhecimentos em sala de aula. 


\title{
3. Análise multimodal da argumentação
}

Tal como pontuamos anteriormente, o discurso científico é multimodal, isto é, ele é construído por diversas linguagens, tais como gráficos, equações, tabelas etc (Lemke, 1998a). Isso destaca a importância do reconhecimento dessas linguagens e seu papel para o entendimento do processo de construção dos conhecimentos científicos e, principalmente, na construção do discurso argumentativo, tanto na ciência quanto na sala de aula (onde se concentra nossa pesquisa). Neste tópico, aprofundaremos essa discussão e mostraremos como é possível construir ferramentas de análise que possibilitam acompanhar a construção do argumento, com as diferentes linguagens que o compõe.

Lemke (op. cit.) define linguagens, ou sistemas de recursos da linguística semiótica, ou ainda modos semióticos como:

[...] abstrações analíticas que são personificadas em práticas sociais: através do discurso material, da escrita e as atividades que provêm contextos dos quais dependem seus significados culturais (LEMKE, op. cit., p.1).

Interpretamos essa definição da seguinte forma:

\begin{abstract}
Linguagens são estruturas abstratas de comunicação fundamentadas no mundo real das interações entre os indivíduos (por exemplo, a fala, gestos, escrita e objetos usados para representar algo), que podem também servir de referência para o ato comunicativo (por exemplo, a construção de um gráfico que serve como base para alguma discussão sobre um fenômeno físico) (BELLUCCO, 2006, p.18).
\end{abstract}

O uso conjunto das linguagens possibilita construir novos significados que não seriam possíveis com a utilização separada delas (LEMKE, 1998b), e esse processo ocorre de duas maneiras (BELLUCCO, 2006; MARQUEZ et. al., 2003):

- Cooperação: quando duas ou mais linguagens são usadas para construir um mesmo significado sobre um conceito ou fenômeno, realizando funções semelhantes. Por exemplo, ao dizer que a temperatura de um gráfico aumentou linearmente, o falante pode usar simultaneamente um gesto que representa a curva do gráfico, ou mesmo, apontar diretamente o local de aumento. Logo, fala, gesto e curva são usados de forma cooperativa para expressar a mesma ideia.

- Especialização: quando duas ou mais linguagens atribuem um significado para um conceito ou fenômeno, realizando funções distintas. Por exemplo, quando se explica a variação de uma entidade em um gráfico, pode-se usar a fala para apontar aumento ou decrescimento, enquanto a curva pode mostrar como se deu 
a variação - linear, exponencial, logarítmica etc - ou seja, introduzindo um novo significado que não seria possível só com as outras linguagens.

Em uma situação de ensino é essencial considerar o uso das diferentes linguagens para a construção dos conhecimentos científicos, ou melhor, apenas uma linguagem, como a oral, não é suficiente para o desenvolvimento dos significados necessários para o entendimento dos fenômenos físicos (BELLUCCO e CARVALHO, 2009a, 2009b).

Laburú et. al. (2011) argumentam que a aprendizagem de conceitos e suas representações são indissociáveis, pois do ponto de vista cognitivo não é possível separar o significado dos conceitos de suas representações, já que o pensamento está associado à organização de signos. Paralelamente a isso, aprender envolve a integração de diversos modos semióticos:

\begin{abstract}
Tanto quanto o processo de pensamento matemático, o pensamento científico igualmente depende da sinergia cognitiva de vários registros e modos de representação, sendo que a satisfatória coordenação dos mesmos vem se manifestar pela rapidez e espontaneidade da atividade cognitiva de conversão dos primeiros, e da tradução e integração dos segundos (LABURÚ et. al., op. cit., p. 472).
\end{abstract}

Além disso, aprender significa transitar entre as várias representações, em diversos caminhos possíveis, a partir da preferência por uma delas que é significativa em nível individual, então surge a necessidade de se variar os diferentes modos semióticos no processo de ensino-aprendizagem. Os autores mostram ainda que o significado se constrói pela soma dos diferentes modos na sala de aula, ponto do qual consideramos impreciso, visto que esse processo não é uma soma simples como nos mostra Lemke (1998a), Marquez et. al. (2003) e Bellucco (2006), no qual uma linguagem tem seu significado multiplicado pela relação com as outras, por meio do processo de especialização referido anteriormente.

$\mathrm{O}$ uso dessas linguagens deve ser consciente, uma vez que o discurso multimodal é comum nas nossas práticas sociais e na sociedade atual, na qual há um predomínio das imagens - uma linguagem culturalmente específica - na construção e transmissão dos significados (PEREIRA e TERRAZAN, 2011).

Laburú et. al. (2011) destacam a necessidade de representações alternadas para aprendizagem dos alunos, mas não indicam se há uma ordem no uso dessas representações. Por exemplo, iniciar uma aula por uma representação algébrica irá facilitar esse processo? Esse não parece ser o caso face à vasta experiência negativa acumulada em cursos tradicionais de ciências, portanto, parece-nos clara a importância 
de se iniciar a aula a partir de modos menos formais, tendo maior possibilidade de conectá-los à estrutura cognitiva/afetiva do estudante.

Por outro lado, Laburú e Silva (2011) mostram que como o discurso científico é elaborado a partir de diferentes linguagens e a compreensão sólida de um conceito deve ser estabelecida no entendimento do seu significado, nas diferentes representações que são complementares e indissociáveis, logo, os estudantes devem compreender e transitar entre as diversas formas de representá-lo.

Observamos esse processo de tradução entre linguagens no ensino de física em Bellucco e Carvalho (2009a e 2009b), no qual o professor fez uma cuidadosa transição entre as linguagens em uma atividade investigativa, que foi essencial para a aprendizagem.

Há ainda uma dependência relativa à área de conhecimento dos tipos de modos semióticos empregados, por exemplo, a física na qual predominam o uso das linguagens gráficas e matemáticas, além das modalidades representacionais fundamentadas em experimentos, manipulações e ações que têm grande importância nos processos cognitivos. Assim, o ensino precisa abordar e exercitar as diferentes representações de forma a construir significados completos, estabelecendo conexões entre elas na forma de uma rede, já que há preferências particulares dos indivíduos por determinado modo semiótico, que serve como referência para apreender outros (LABURÚ e SILVA, 2011).

No contexto do ensino de ciências, é fundamental destacar que as linguagens visuais e matemáticas possuem componentes tipológicos e topológicos (LEMKE, 1998a, 1998b, 1999, 2002), constituindo uma forma híbrida de representação/interpretação dos fenômenos naturais:

- Recursos tipológicos das linguagens são usados para classificar por oposição os contextos culturais (LEMKE, 1999). Assim, quando usamos "quente" ou "frio" para definir a temperatura de um objeto, nossa fala possui meios que, ao classificar, definem condições excludentes. Dessa forma, esses recursos são marcados, em muitos casos, por ausência de precisão. São exemplos de tais categorias: longe e perto; alto e baixo; momento angular e momento linear; condução, convecção e irradiação, eixo das abscissas, eixo das coordenadas etc.

- Recursos topológicos representam variações contínuas (ou quase) nas propriedades dos fenômenos naturais, tais como: temperatura, pressão, momento angular, momento linear, calor etc. É importante destacar que cada uma dessas 
entidades pode variar dentro da topologia dos números reais (LEMKE, 1999), o que implica uma interpretação bastante precisa dos fenômenos físicos e a dependência funcional de variáveis. São também alguns exemplos desses recursos: equações, desenhos, gestos, gráficos e qualquer tipo de representação visual.

Destacamos que tanto na ciência quanto no seu ensino, a linguagem oral e a escrita não dão conta de descrever, de uma forma precisa: o movimento de um projétil no espaço, a variação da temperatura de um líquido, a topologia de uma montanha, o movimento de uma molécula em um gás, e assim por diante. Além disso:

Enquanto certas representações carregam uma composição mais apropriada para conceituar significados topológicos, outras são mais adequadas para conceituar significados tipológicos. Um exemplo deste último é a linguagem verbal. A característica tipológica é mais poderosa para expressar raciocínios semânticos, qualificar ideias ou realizar relações entre categorias. Opera, primariamente, por contrastes entre aspectos mutuamente exclusivos, sendo relativamente limitada e com poucos recursos para expressar significados quantitativos ou de grau. Por outro lado, quando se faz necessário estabelecer referências quantitativas, que necessitam expressar grau, as linguagens topológicas de tipo visual, como gestos, desenhos, e a prática experimental que nos interessa ressaltar, são recursos semióticos que melhor exprimem significados desta natureza e apresentam maior eficácia de tratamento do que a linguagem tipológica (LABURÚ e SILVA, op. cit., p.730).

Consideramos fundamental que essas características tipológicas e topológicas sejam explicitadas aos estudantes e discutidas com eles para que os mesmos compreendam plenamente essas linguagens e seus usos na ciência, possibilitando que os fenômenos de estudo sejam visualizados e interpretados nas representações (BELLUCCO, 2006).

Destacada a importância das diferentes linguagens no discurso e na construção do conhecimento científico em sala de aula, iniciamos agora a discussão de um instrumento para análise multimodal da argumentação, que foi usado como referência para a construção de uma ferramenta mais ampla para o estudo da argumentação matemática em aulas investigativas. 


\subsection{Múltiplas linguagens e a argumentação}

Para observar o processo de argumentação, por meio do uso das diferentes linguagens na construção de cada argumento, usamos o software Videograph ${ }^{12}$, que permite visualizar um vídeo, transcrever as falas, e ainda, criar categorias e subcategorias para análise, as quais relacionamos respectivamente a cada elemento do padrão de Toulmin (TAP), isto é, para cada dado, garantia, apoio, qualificador modal, refutação e conclusão, associamos as principais linguagens encontradas empiricamente nas aulas, constituindo o instrumento a seguir:

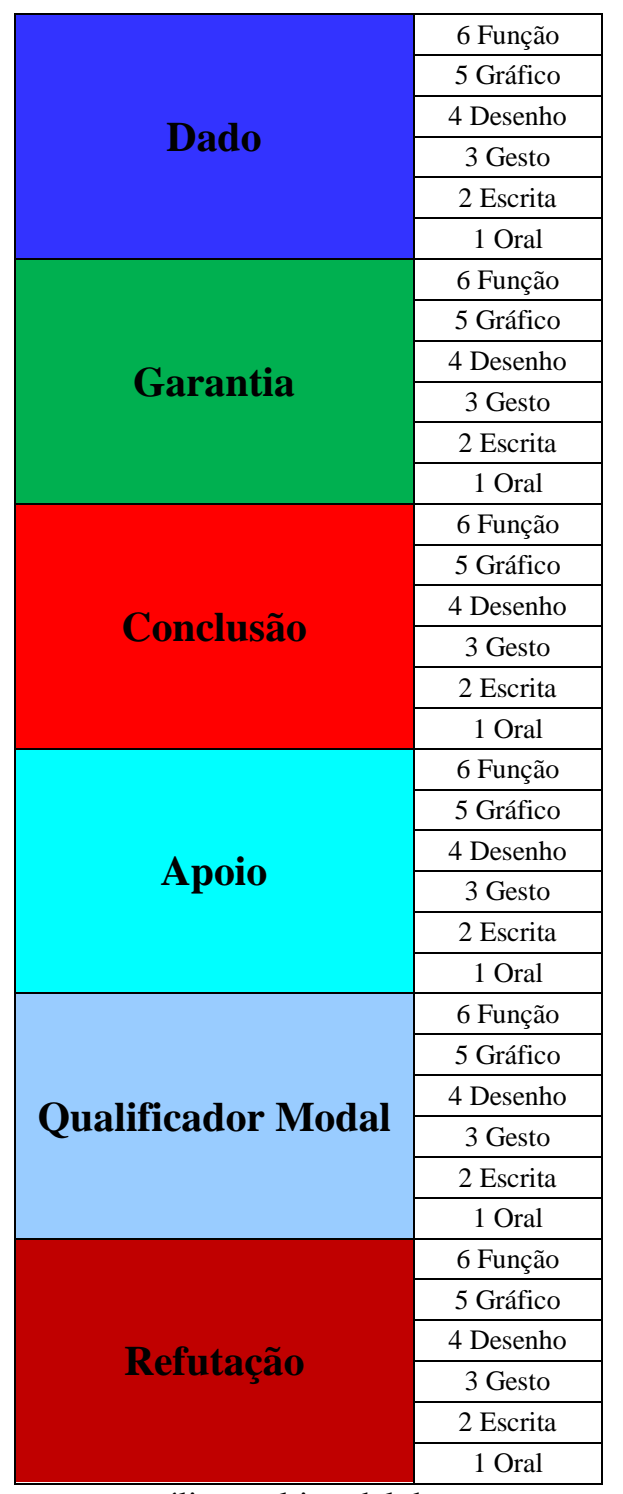

Figura 6: Instrumento para análise multimodal dos argumentos e suas categorias

\footnotetext{
${ }^{12}$ Disponível em: http://www.dervideograph.de/enhtmStart.html (Acessado em 01 de novembro de 2014).
} 
Este software permite construir um gráfico temporal, com o qual se pode simultaneamente acompanhar e destacar cada categoria e suas subdivisões no exato momento em que elas aparecem. Na parte superior desse gráfico encontra-se a escala de tempo, na qual cada divisão equivale a dois segundos ${ }^{13}$. Usa-se o padrão "min:s" para o tempo.

As linhas do gráfico são preenchidas com a cor da categoria quando ocorre uma delas na posição da linguagem que está em uso (conforme numeração da figura 6). A categoria é repetida no gráfico quando ocorre mais de uma linguagem ao mesmo tempo. A figura 7 a seguir mostra o gráfico construído para um argumento:

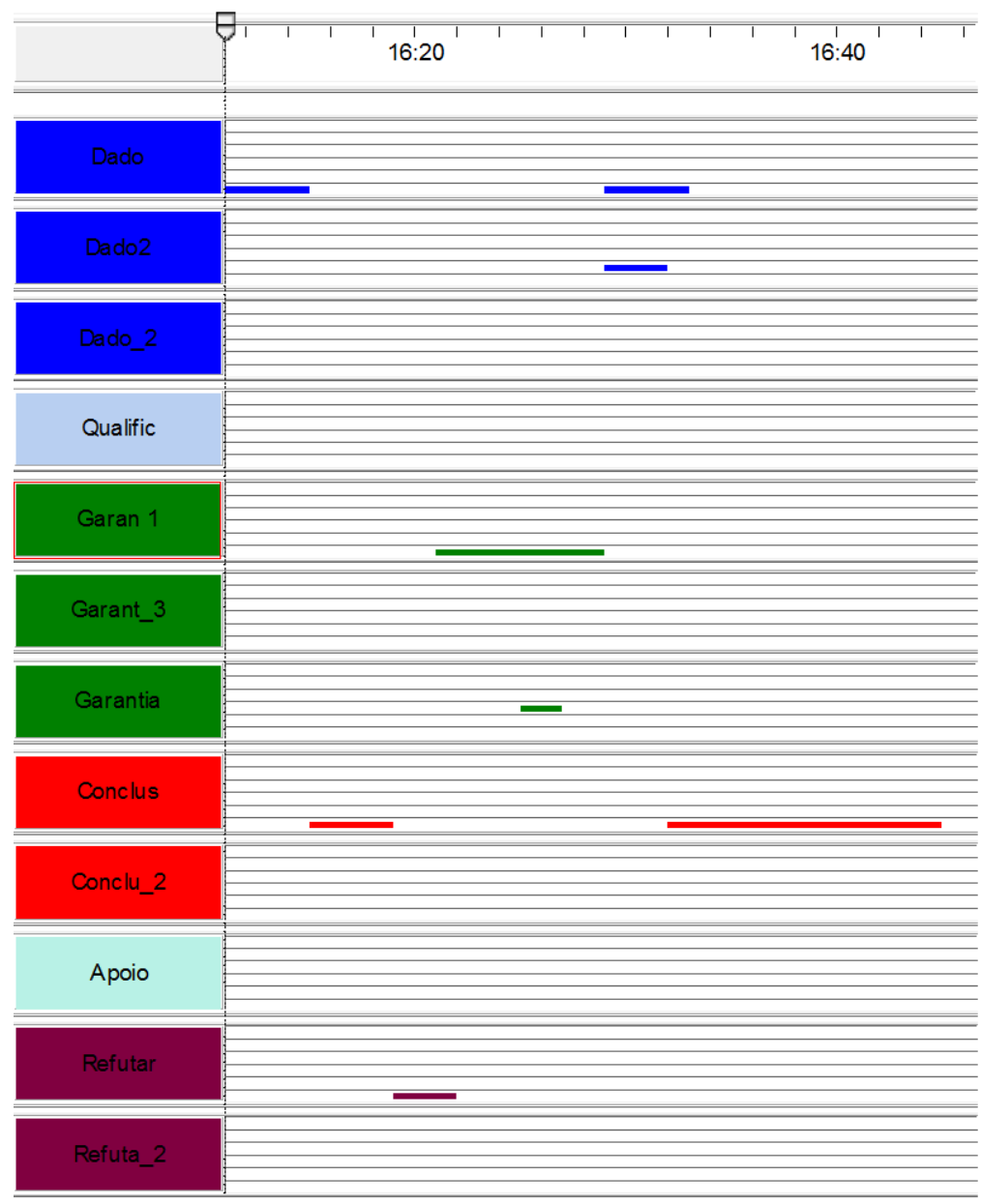

Figura 7: Gráfico temporal da argumentação multimodal

No exemplo acima, houve o uso simultâneo das linguagens oral (Garant 1) e gráfica (Garantia), para a construção da garantia. O mesmo vale para a categoria dado, em que houve o uso das linguagens oral (dado) e escrita (dado2).

Apresentamos no próximo tópico um exemplo de aplicação dessa proposta de análise em uma situação de ensino-aprendizagem.

\footnotetext{
${ }^{13}$ Essa escala pode ser alterada pelo usuário.
} 


\subsubsection{Um exemplo do uso da ferramenta para análise multimodal da argumentação}

Como exemplo de análise selecionamos parte de sequência de aulas investigativas envolvendo um laboratório aberto, no qual o professor apresenta um problema aberto, seguido do processo de levantamento das concepções dos alunos que são tomadas como hipóteses, por meio de questões que estimulam a participação. A partir de ampla discussão sobre a validade dessas ideias, é traçado um plano experimental para coleta de dados, tomando as hipóteses como condições de experimentação.

A análise dos dados dessas aulas pode levar ao desenvolvimento de várias características da ciência, como a argumentação, uso de aproximações, elaboração de gráficos e tabelas para interpretar o fenômeno etc (BELLUCCO \& CARVALHO, 2009a, 2009b; CAPECCHI \& CARVALHO, 2006; CARVALHO et. al. 1999).

Além disso, em sala de aula, a passagem dos dados da tabela para o gráfico, e posteriormente, para uma função que descreva o fenômeno não é simples e compreende a cooperação e especialização de várias linguagens, para a construção dos significados científicos que envolvam a relação entre variáveis e/ou entidades, e para que os estudantes possam "visualizar" o fenômeno na representação matemática (BELLUCCO, 2006; BELLUCCO \& CARVALHO, 2009a e 2009b) ${ }^{14}$.

A atividade, localizada ao longo de uma sequência de ensino investigativa sobre calor e temperatura, foi aplicada em uma turma do primeiro ano do Ensino Médio com cerca de quarenta alunos, em uma escola pública do estado de São Paulo em 2000, durante o período de quatro aulas duplas que foram registradas em vídeo. O objetivo era responder a questão: “como a água aquece?”.

Seguem as principais hipóteses formuladas pelos estudantes a partir do diálogo com o professor sobre a questão de pesquisa:

- Estabilidade da temperatura - chega um momento (em torno de $100^{\circ} \mathrm{C}$ ) em que temperatura não aumenta mais.

\footnotetext{
${ }^{14}$ Este processo se aproxima das construções científicas em que os cientistas, ao se referirem sobre um gráfico ou equação, falam diretamente sobre o fenômeno de estudo (ROTH, 2003). E ainda, eles utilizam diversos modos semióticos para estruturar as relações entre as entidades de estudo e multiplicar seus significados (LEMKE, 1998a), por meio dos processos de cooperação e especialização dessas representações (MARQUEZ et. al., 2003).
} 
- Não linearidade do aquecimento - a temperatura aumenta mais rápido no começo e o processo é mais lento próximo da fervura.

- Tipo de recipiente - o material do recipiente interfere na taxa de aumento.

- Com ou sem tampa - com tampa a taxa de aumento é maior.

- Mais água ou menos água - a taxa de aumento é menor com mais água.

- Mais ou menos energia - com mais energia a taxa de aumento é maior.

Cada hipótese transformou-se em uma condição de experimentação padronizada que deveria ser desenvolvida por apenas um dos oito grupos de cinco alunos $^{15}$, resultando em uma tabela contendo temperatura em função do tempo para cada concepção/suposição apresentada. Da comparação das tabelas, verificou-se apenas a estabilidade da temperatura, logo, houve a necessidade de construção do gráfico e posteriormente da função de aquecimento para cada forma de realizar a experiência, com o objetivo de confirmar ou refutar cada concepção. O quadro a seguir traz um panorama da sequência de ensino:

\begin{tabular}{|c|c|}
\hline Aulas & Descrição \\
\hline 1 e 2 & $\begin{array}{c}\text { Formulação do problema, levantamento de hipóteses e definição do } \\
\text { plano experimental }\end{array}$ \\
\hline 3 e 4 & Realização das medidas, construção e comparação das tabelas \\
\hline 5 e 6 & Construção dos gráficos com os dados da tabela \\
\hline 7 e 8 & Extração da função de aquecimento a partir do gráfico \\
\hline
\end{tabular}

Quadro 5: Atividade de laboratório aberto

Nas duas últimas aulas da sequência, encontra-se o estudo minucioso das funções dos diferentes grupos, no qual o teste de hipóteses foi concluído, produzindo um argumento para cada uma delas. Dessa forma, procuramos utilizar o instrumento apresentado nas figuras 6 e 7 para a análise de cada hipótese, verificando como as diferentes linguagens se relacionam aos elementos do TAP e, posteriormente, qual o papel da matemática na elaboração dos argumentos nesse contexto. A escolha desse recorte se deve à intensa presença das linguagens matemáticas nas aulas 7 e 8 para construção da explicação, o que condiz com o foco deste trabalho.

\footnotetext{
${ }^{15}$ Seria muito cansativo se todos os grupos testassem todas hipóteses, utilizando um tempo não disponível nas aulas. Assim, como ocorre nos laboratórios, cada "grupo de pesquisa" trabalha com um aspecto do fenômeno e os dados obtidos são partilhados coletivamente para análise geral e resolução do problema ou construção da explicação científica.
} 
Para a análise dos argumentos produzidos apresentamos a transcrição do tempo, da linguagem oral e da visual (usamos negrito, sublinhado e itálico onde houve simultaneidade do uso de linguagens), seguida dos gráficos das categorias gerados pelo videograph. Mostramos abaixo três exemplos de argumentos multimodais - a análise completa é encontrada em Bellucco e Carvalho (2012).

\begin{tabular}{|c|l|l|}
\hline \multicolumn{3}{|c|}{ ARGUMENTO 1: ESTABILIDADE DA TEMPERATURA } \\
\hline Tempo (min:s) & \multicolumn{1}{|c|}{ Linguagem oral } & \multicolumn{1}{|c|}{ Visual/Escrita } \\
\hline 39:01 - 39:21 & $\begin{array}{l}\text { P: vamos tentar ver os dados ... chega ((turma ainda está } \\
\text { agitada)) as nossas hipóteses ... vamos pegar as nossas } \\
\text { hipóteses ... a primeira que a gente tinha feito era sobre o } \\
\text { problema da estabilidade da temperatura... }\end{array}$ & $\begin{array}{l}\text { Representa reta } \\
\text { horizontal com as }\end{array}$ \\
\hline $39: 21-39: 41$ & $\begin{array}{l}\text { P: e essa conclusão a gente tirou quando comparou as } \\
\text { tabelas ... viu que a temperatura chega numa hora que se } \\
\text { mantém --durante a fervura ... segunda coisa que a gente } \\
\text { tinha pensado ... } \\
\text { A2: O quê? } \\
\text { P: qual a hipótese que a gente tinha feito lá no começo do } \\
\text { trabalho? (Tabela é a garantia nos desenhos) }\end{array}$ \\
\hline $39: 41-40: 01$ & $\begin{array}{l}\text { A2: que ela chegava numa temperatura e estabilizava } \\
\text { P(a): que ela chegava numa temperatura e estabilizava ... a } \\
\text { gente entendeu isso quando comparou as tabelas na lousa ... } \\
\text { qual era a outra? olha no caderno ... ((P pega vassoura e } \\
\text { varre cacos do béquer quebrado)) } \\
((\mathrm{P} \text { aguarda respostas, enquanto varre / alunos agitados } \\
\sim 30 \text { ")) (Tabela como garantia) }\end{array}$ \\
\hline
\end{tabular}

Quadro 6: Estabilidade da temperatura

O professor apresenta o dado oralmente apoiado por um gesto cooperativo, ou seja, a temperatura se mantém a partir de certo ponto (39:01 - 39:21). Uma garantia é inserida por meio da cooperação entre a linguagem oral e a visual - tabela - (que não estava explícita na lousa) de 39:21 a 39:26. Isso levou a conclusão apresentada oralmente de que a temperatura se mantém durante a fervura (39:26 - 39:41). O padrão de argumento se repete a seguir de forma similar, com o dado fornecido pela aluna A2. 


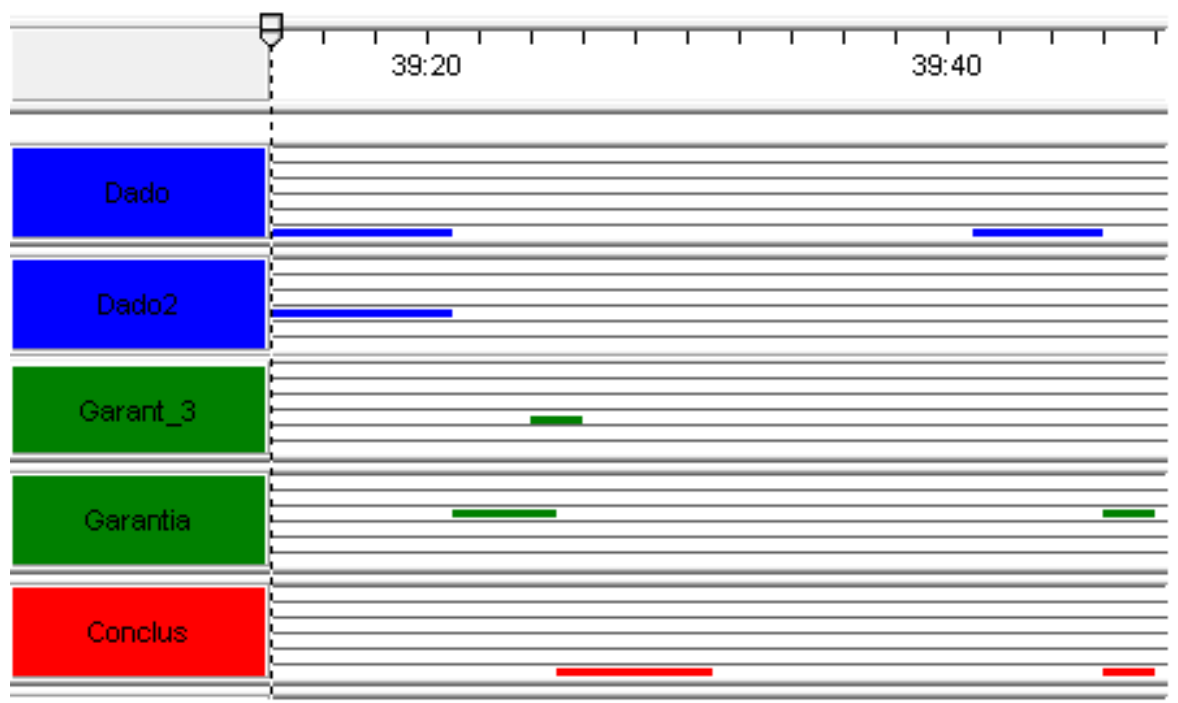

Figura 8: Argumento 1 - Estabilidade da temperatura

\begin{tabular}{|c|c|c|}
\hline \multicolumn{3}{|c|}{ ARGUMENTO 2: TESTE DE HIPÓTESES - NÃO LINEARIDADE DO AQUECIMENTO } \\
\hline Tempo (min:s) & Linguagem oral & Visual/Escrita \\
\hline 40:01 - 40:21 & $\begin{array}{l}\text { P(b): qual era a outra hipótese? Vamos lá ((continua varrendo } \\
\text { enquanto aguarda participação dos alunos / há muita agitação na } \\
\text { classe } 20 "))\end{array}$ & \\
\hline 40:41 - 41:01 & $\begin{array}{l}\text { P: ((Termina de varrer)) dá pra parar a conversa e a gente fechar } \\
\text { o trabalho?! ((pausa 7")) Vamos parar com isso? ((pausa } \\
\text { 5"))...primeira hipótese que a gente tinha... vamos lá... }\end{array}$ & \\
\hline 41:01- 41:21 & $\begin{array}{l}\text { P ...quem tem o caderno aí? volta ... quem tava na aula que a } \\
\text { gente viu isso? } \\
\text { Alunos: aumenta no começo... } \\
\text { P: a temperatura aumenta MAIS no começo e depois vai mais } \\
\text { devagar ... a única coisa que a gente poderia ver nisso é Quando } \\
\text { chega perto da fervura ... né? quando já tá... }\end{array}$ & \\
\hline 41:21- 41:41 & $\begin{array}{l}\text { P: ...parte da água fervendo e parte não ... realmente ela faz uma } \\
\text { curvinha ... mas no resto não ... né? até os oitenta ... oitenta e } \\
\text { cinco graus não ... a gente poderia escrever isso ... até oitenta e } \\
\text { cinco graus a temperatura }\end{array}$ & $\begin{array}{c}\text { Gesticula } \\
\text { Simula uma reta } \\
\underline{\text { ascendente }}\end{array}$ \\
\hline 41:41- 42:01 & P: ... a temperatura aumenta de um jeito só ... & $\begin{array}{l}\text { Escreve na lousa: } \\
\text { "- até } 85^{\circ} \mathrm{C} \text { a } \\
\text { temperatura } \\
\text { aumenta de um } \\
\text { jeito só” }\end{array}$ \\
\hline 42:01 - 42:21 & $\begin{array}{l}\text { P: ...REPAREM no que a gente está fazendo ... depois de fazer } \\
\text { todo este estudo ... nós estamos checando as NOSSAS hipóteses } \\
\ldots \text {.. do começo do trabalho ... tá aqui ... a temperatura aumenta ... a } \\
\text { gente dizia que aumentava... }\end{array}$ & $\begin{array}{l}\text { Aponta para as } \\
\text { conclusões na lousa }\end{array}$ \\
\hline $42: 21-42: 41$ & $\begin{array}{l}\text { P: mais rápido e depois aumentava mais devagar ... só fica mais } \\
\text { devagar quando chega perto da fervura .... o que mais? Qual era a } \\
\text { outra hipótese? ((pausa 10")) }\end{array}$ & $\begin{array}{l}\text { Aponta para as } \\
\underline{\text { conclusões na lousa }}\end{array}$ \\
\hline
\end{tabular}

Quadro 7: Não linearidade do aquecimento 
De 41:06 a 41:13 os alunos apresentam outro dado (aumenta no começo) oralmente a partir provavelmente da escrita no caderno (conforme requisição do docente).

A seguir o professor apresenta o gráfico como garantia, (de 41:13 a 41:49 - até os oitenta ... oitenta e cinco graus não ... a gente poderia escrever isso... até oitenta $e$ cinco graus a temperatura ... a temperatura aumenta de um jeito só...), e ao mesmo tempo, como refutador ("quando já tá... parte da água fervendo e parte não ... realmente ela faz uma curvinha ... mas no resto não ... né?"), que é amparado cooperativamente pelo gesto que não invalida a conclusão, pois há somente uma pequena região em que a linearidade não se enquadra (de 41:13 a 41:26).

Isso permite a conclusão de que a maior parte do intervalo de aquecimento da água é linear, que é introduzida por meio da cooperação da linguagem oral (de 41:26 a 41:49) e escrita (de 41:26 a 42:01).

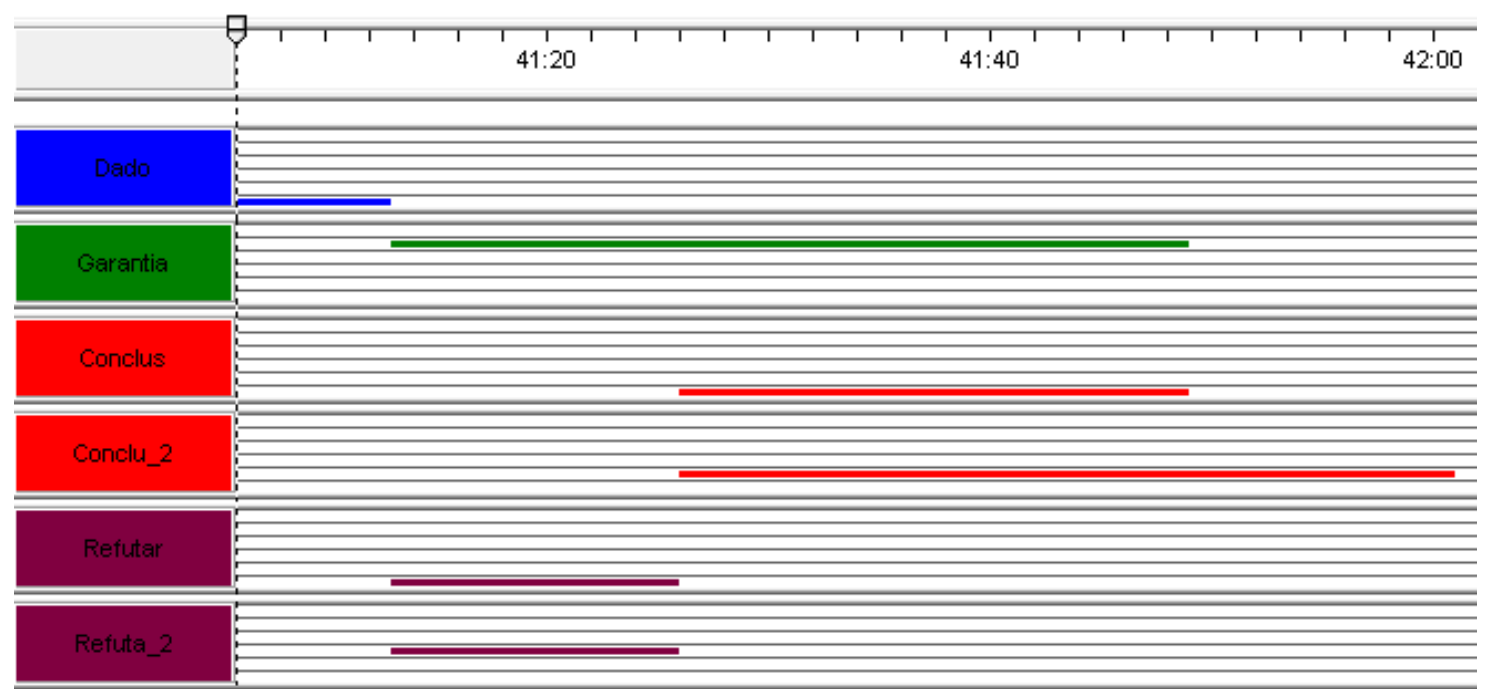

Figura 9: Argumento 2 - Não linearidade do aquecimento 


\begin{tabular}{|c|c|c|}
\hline \multicolumn{3}{|c|}{ ARGUMENTO 3: TESTE DE HIPÓTESES - RECIPIENTES DIFERENTES } \\
\hline Tempo (min:s) & Linguagem oral & Visual/Escrita \\
\hline $42: 21-42: 41$ & $\begin{array}{l}\text { A2: com recipientes diferentes... } \\
\text { P: com recipientes diferentes... }\end{array}$ & \\
\hline $42: 41-43: 01$ & $\begin{array}{l}\text { A: fechado ou aberto } \\
\text { P: então veja... com recipientes diferentes a gente tem } \\
\text { aqui ó ... aqui foi feito com vidro ... aqui foi feito com } \\
\text { alumínio ... quê que a gente percebe de um pro outro? } \\
\text { A2: no alumínio a temperatura... } \\
\text { P: aumenta... } \\
\text { A2: aumenta... é maior ... }\end{array}$ & \\
\hline $43: 01-43: 21$ & 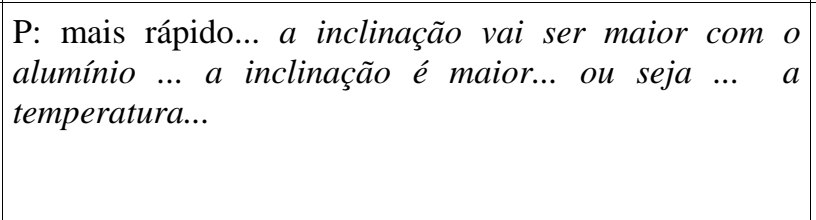 & $\begin{array}{l}\text { Escreve na lousa: “- a } \\
\text { inclinação é maior com } \\
\text { alumínio, ou seja, a } \\
\text { temperatura aumenta mais } \\
\text { rápido: }\end{array}$ \\
\hline $43: 21-43: 41$ & $\begin{array}{l}\text { P: aumenta mais rápido ... a gente pode até comparar } \\
\text { quantas vezes mais rápido ... né? aqui tá em torno de } \\
\text { nove ... aqui tá em torno de doze } \ldots \text { então um terço a } \\
\text { mais de rapidez para o }\end{array}$ & $\begin{array}{l}\text { Escreve na lousa: } \\
\text {-vidro: } \theta=9 t+18 \\
\text {-alumínio: } \theta=12 t+18^{\prime \prime} \\
\text { Indica valores na lousa } \\
\end{array}$ \\
\hline $43: 41-44: 01$ & $\begin{array}{l}\text { P: material ... né ... no vidro foi nove t mais dezoito ... } \\
\text { no alumínio deu doze t mais dezoito ... outra hipótese? }\end{array}$ & \\
\hline
\end{tabular}

Dois dados são apresentados oralmente por alunos distintos, o primeiro referese a recipientes diferentes, que é enfatizado neste momento pelo professor, e o segundo, relativo a recipientes abertos ou fechados, desenvolvido a seguir.

Primeiro, as linguagens algébrica (coeficiente das equações), oral e gestual (aponta valores dos coeficientes) cooperam para formar a garantia, ou seja, estabelecem a conclusão de que o aquecimento mais rápido ocorre com o alumínio (42:54 a 43:02). Segundo, a partir da leitura das equações, a garantia é reforçada pela cooperação entre a linguagem oral e a escrita, em que o professor escreve na lousa de 43:02 a 43:16, permitindo a sistematização escrita da conclusão apresentada anteriormente.

Por fim, o docente apresenta outra garantia comparando os coeficientes das equações (43:27 a 43:37), e para que isto ocorra, foi necessária a cooperação entre as linguagens oral, algébrica e gestual. Isso permitiu concluir (por meio da cooperação entre a linguagem oral e a algébrica), que o aquecimento com o alumínio é cerca de um terço mais rápido. 


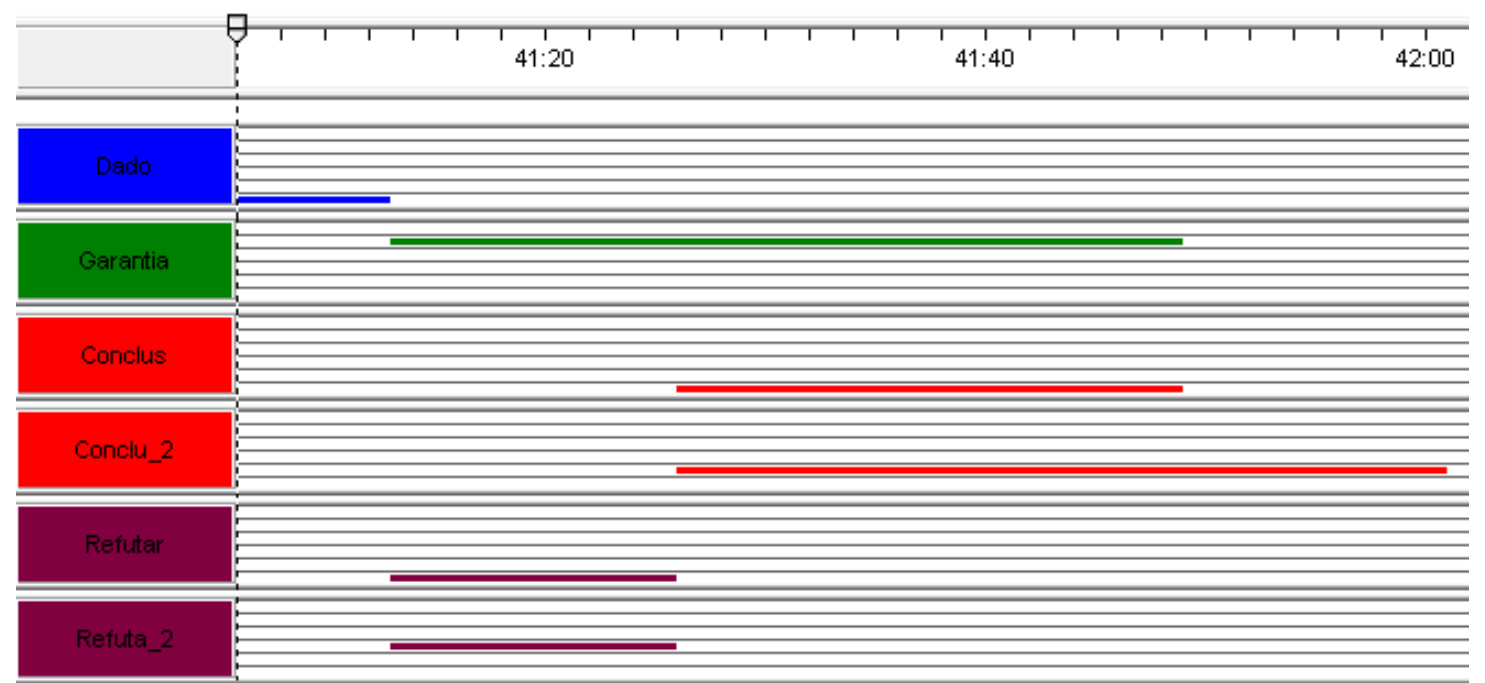

Figura 10: Argumento 2 - Não linearidade do aquecimento

A partir dessa análise, que engloba o uso do TAP e de uma concepção multimodal do discurso, verificamos que elementos da matemática atuam predominantemente como uma garantia que ampara dados e conclusões. Em todos os casos, o uso das linguagens matemáticas (algébrica, gráfica e visual/tabela) foi fundamental para o estabelecimento da garantia do argumento, que não teria força sem elas, mesmo que a linguagem verbal as estivesse apoiando.

A seguir esboçamos um instrumento para avaliar a argumentação matemática em aulas de física, que leva em conta os conhecimentos debatidos nos três primeiros capítulos deste trabalho. 


\section{Uma ferramenta de análise da argumentação matemática em sala de aula}

Ao longo dos primeiros capítulos, buscamos compreender a argumentação de uma perspectiva geral e no ensino de ciências, com o objetivo de construir uma ferramenta de análise que permita estudar os processos argumentativos que envolvem a matemática em aulas de física. Nosso objetivo é responder as seguintes questões:

Como o conhecimento matemático é demandado na construção dos argumentos científicos dos estudantes em aulas investigativas de física?

Quais são as dificuldades enfrentadas pelos alunos ao longo desse processo?

Como a linguagem matemática torna-se necessária para a construção dos significados científicos?

Como se dá a apropriação desse conhecimento matemático?

Dessa forma, encontramo-nos no contexto multimodal, no qual propomos a seguir uma ferramenta de análise que considera essa natureza do discurso científico e os estudos sobre argumentação apresentados, incluindo suas características campodependentes e os conhecimentos específicos sobre argumentação matemática apresentados previamente.

\subsection{Avaliando a argumentação matemática em uma aula de física}

Além de nossas questões de pesquisa, formulamos algumas hipóteses no desenvolvimento deste trabalho com base nos referenciais apresentados, que nortearam a construção da nossa ferramenta de análise:

- O uso das hierarquias da abdução para análise de situações de ensino e aprendizagem tanto em aulas de matemática quanto de física. Optamos pela proposta de Pedemonte e Reid (2011) apresentada na figura 5 (tópico 1.3.2.), que permite observar a abdução no TAP e avaliar o domínio do conhecimento científico na construção de dados que suportem as conclusões. Conforme exemplificamos, quando há uma abdução sobrecodificada, há um domínio relativo de uma regra ou garantia para inferir um dado que leva à conclusão (o que já é interessante dependendo dos saberes que o contexto exige). Já as 
abduções sobcodificada (níveis 1 e 2) e criativa denotam um domínio de vários conteúdos, no primeiro caso inferindo os dados a partir de várias garantias que amparam a conclusão e no segundo caso criando uma nova garantia que gera os dados para a conclusão, o que significa que o aluno deve refletir criticamente sobre os conteúdos que ele domina. Vale destacar que no trabalho empírico com os dados encontramos apenas casos de abdução sobrecodificada, logo, não foi necessário a hierarquização desse conceito ao longo deste trabalho (isso ficará explícito no capítulo 7).

- A análise dos critérios campo-dependentes da argumentação científica segundo as seguintes práticas: levantamento e teste de hipóteses e abdução; seriação, classificação e organização de informações; explicação; justificativa (uso de definição, apelo à analogia ou comparações, exemplos, atributos, consistência com outros conhecimentos - incluindo a experiência e a metafísica - e plausibilidade), previsão, dedução; indução, raciocínio lógico e proporcional. Partimos ainda da hipótese de que diferentes práticas ocorrerão em diferentes momentos do ciclo argumentativo, que é desencadeado a partir de atividades investigativas. Além disso, a explicação é uma categoria mais abrangente que é parte desse ciclo.

- A abdução deve aparecer no processo de levantamento e teste de hipóteses, e ainda, que as refutações são importantes no estabelecimento das condições de consistência e a plausibilidade do conteúdo científico, visto que elas indicam os limites de uma alegação. Assim, as refutações encontram-se no interior do processo de justificativa.

- A qualidade da argumentação pode ser analisada pelas duas categorias apresentadas na tabela 3 (tópico 2.2.1.), ou seja, (1) formas para coordenação entre alegações e evidências e (2) conteúdos para coordenação entre alegações e evidências. A categoria 1 permite avaliar como as alegações são respaldadas pelas justificativas. Um argumento coerente e de qualidade, principalmente no contexto da ciência, deve apresentar justificativas e relacionar todas as evidências disponíveis, além de explicitar os seus limites. Já a categoria 2, engloba as práticas de justificação que envolvem os critérios campo-dependentes da argumentação. 
- Ainda na qualidade da argumentação é importante refletir sobre as linguagens por meio do qual se apresentam os conteúdos tanto na categoria 1 (forma para a coordenação entre alegações e evidências), quanto na categoria 2 (conteúdos para a coordenação entre alegações e evidências), ou seja, durante a argumentação científica na sala de aula há necessidade de se expressar principalmente por meio das linguagens - ou modos de comunicação - verbal, escrita, gestual, visual (desenhos, esquemas e tabelas), gráfica e algébrica. Nessa situação, os processos de cooperação e especialização são essenciais.

- O uso do TAP relacionando seus elementos às diferentes linguagens com o auxílio do software videograph (BELLUCCO e CARVALHO, 2012), possibilita identificar a situação argumentativa e o papel da linguagem matemática e as outras linguagens na construção dos argumentos dos estudantes, incluindo suas características campo-dependentes. Aqui é necessária uma ressalva a fim de tornar o instrumento mais prático, evitando o excesso de informações e a dificuldade de visualização das categorias. Sendo assim, ao invés de destacar todos os elementos do TAP diretamente, deve-se identificar situações nas quais existam justificativas e a ocorrência das outras características campodependentes para coordenar alegações e evidências no processo de construção do conhecimento em sala de aula (que garantem que a situação seja argumentativa), para o uso da ferramenta.

Com o intuito de investigar as questões e hipóteses apresentadas anteriormente, desenvolvemos uma estrutura de análise, inspirada no instrumento apresentado no capítulo 3 (BELLUCCO e CARVALHO, op. cit.), partindo (1) da identificação das etapas do ciclo argumentativo, (2) das características campo-dependentes da argumentação e (3) das linguagens em uso, que são mostradas em gráficos temporais no software Videograph. Isso permite uma estruturação da situação argumentativa e a discussão da sua qualidade. Esquematicamente essas ideias se organizam da seguinte maneira: 


\section{Ciclo Argumentativo}

Cuidado com os dados existentes: ordenar as informações para destacar sua devida importância durante a investigação, na discussão com os pares, utilizando conhecimentos previamente adquiridos.

Definição das variáveis relevantes ao problema: envolve também a formulação de hipóteses, o uso de justificativas e previsões, validando e extrapolando as informações do contexto.

Explicação: uso das construções elaboradas para relacionar as informações e as variáveis, obtendo uma ideia mais concreta sobre os fenômenos e previsões em questão.

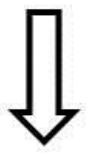

Aspectos campo-dependentes da argumentação

Levantamento e teste de hipóteses e abdução; seriação, classificação e organização de informações; justificativa (uso de definição, apelo à analogia ou comparações, exemplos, atributos, consistência com outros conhecimentos - incluindo a experiência e a metafísica - e plausibilidade), previsão, dedução; indução, raciocínio lógico $e$ proporcional.
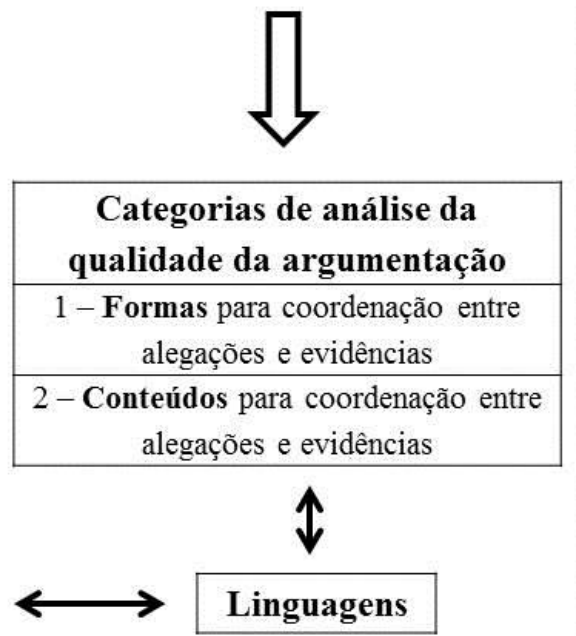

Figura 11: Análise da argumentação campo-dependente

No software as categorias são arranjadas da seguinte maneira:

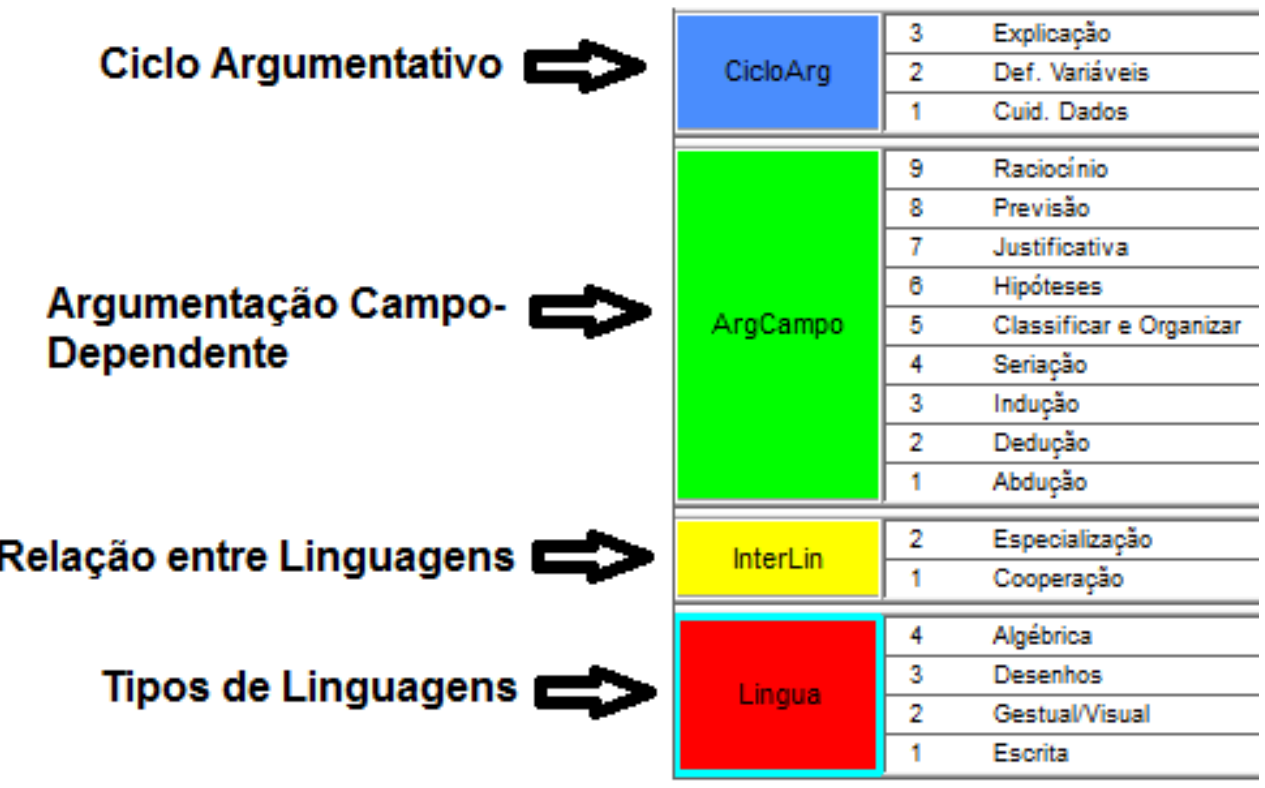

Figura 12: Categorias de análise da argumentação matemática no software Videograph

Essa estruturação facilita a visualização temporal dos elementos da linguagem matemática (Lingua) e as relações estabelecidas entre eles (Interlin) ao longo do processo argumentativo, representado pelo ciclo argumentativo (CicloArg) e as 
características campo-dependentes (Argcampo). A partir dessa discussão, é possível estudar a qualidade argumentativa da situação e os conhecimentos matemáticos demandados nela.

Dessa forma, traçaremos um perfil geral da argumentação matemática na sala de aula em atividades investigativas, portanto, é necessária a apresentação de uma sequência de ensino que propicie o aparecimento dessas características, que é o foco do próximo capítulo. 


\section{Uma sequência de ensino investigativa sobre quantidade de movimento, sua conservação e as leis de Newton}

Neste capítulo, apresentamos uma proposta de uma Sequência de Ensino Investigativa (SEI) para o ensino de quantidade de movimento ${ }^{16}$, sua conservação e as leis de Newton, que estimule os alunos a argumentar segundo os pontos discutidos no tópico anterior.

A seleção de uma metodologia investigativa como pano de fundo da sequência de ensino é pautada nas pesquisas que abordamos previamente (ERDURAN, 2007; JIMÉNEZ-ALEIXANDRE et. al., 2000; JIMÉNEZ-ALEIXANRE e BUSTAMANTE, 2003; MACDONALD e KELLY, 2012; SAMPSON e CLARK, 2006; SAMPSON et. al., 2012; SANDOVAL e MILLWOOD, 2007; SASSERON e CARVALHO, 2011a e 2011b; SASSERON, 2008), as quais demonstram que esse tipo de proposta é profícuo no desencadeamento de situações argumentativas.

Optamos pelo tema quantidade de movimento devido à sua fundamental importância tanto (1) na história da física quanto (2) no seu desenvolvimento contemporâneo. No primeiro caso, Carvalho (1989) enfatiza que:

A conservação da quantidade de movimento foi o germe da Física clássica e desempenhou um papel básico na formulação das leis de Newton. Com ela se estabeleceu uma rede de relações lógicas entre massa, velocidade, tempo, força impulso e aceleração (p.9).

No segundo caso, no domínio da física quântica, sobre o conceito de momento (ou quantidade de movimento), Feynman et. al. (2008) destacam que:

[...] na mecânica quântica ocorre que momento é uma coisa diferente, não é mais mv. É difícil definir exatamente o que significa a velocidade de uma partícula, mas momento ainda existe. Em mecânica quântica a diferença é que quando as partículas são representadas como partículas, o momento ainda é mv, mas quando as partículas são representadas como ondas, o momento é medido pelo número de ondas por centímetro: quanto maior esse número de ondas, maior o momento. A despeito das diferenças, a lei de conservação de momento vale também na mecânica quântica. Embora a lei $\mathrm{f}=\mathrm{ma}$ seja falsa e todas as derivações de Newton estivessem erradas para a conservação do momento, na mecânica quântica, contudo, no fim, essa lei particular se mantém! (p.10-9).

\footnotetext{
${ }^{16}$ Muitos livros de terceiro grau usam a denominação "momento linear", porém, mantivemos a denominação "quantidade de movimento", pois é a expressão mais usada nos livros didáticos para o ensino médio.
} 
Além disso, nossa experiência nas escolas públicas e privadas revela que esses conteúdos, apesar de sua relevância histórica e atual, quase nunca são abordados nas salas de aula (BELLUCCO, 2012).

Antes de apresentar a sequência didática, discutimos brevemente os fundamentos da proposta de ensino-aprendizagem adotada.

\subsection{As Sequências de Ensino Investigativas}

As Sequências de Ensino Investigativas (SEIs) surgiram no Laboratório de Pesquisa em Ensino de Física (LaPEF) da Faculdade de Educação da Universidade de São Paulo, a partir da sistematização de diversas pesquisas realizadas por seus mestrandos e doutorandos e de ampla revisão bibliográfica nos principais periódicos de ensino de ciências. Carvalho (2011a) apresenta alguns pontos relevantes para a construção de conhecimentos pelo indivíduo que devem ser considerados no planejamento das SEIs:

- A relevância de um problema para um início da construção do conhecimento.

- A passagem da ação manipulativa para a ação intelectual.

- A importância da tomada de consciência dos próprios atos para a construção do conhecimento.

- As diferentes etapas das explicações científicas.

Além disso, a autora destaca que para que haja interações sociais - outro ponto fundamental para o processo de construção do conhecimento - entre os participantes das SEIs, é necessário considerar os seguintes pontos:

- o estímulo à participação ativa do estudante;

- a importância da relação aluno-aluno;

- o papel do professor como elaborador de questões;

- a criação de um ambiente encorajador;

- o ensino a partir do conhecimento que o aluno traz para a sala de aula;

- o conteúdo (o problema) tem que ser significativo para o aluno;

- a relação ciência, tecnologia e sociedade;

- a passagem da linguagem cotidiana para a linguagem científica. 
É importante destacar ainda, que os problemas nas SEIs devem estar contidos na cultura dos estudantes e serem interessantes a ponto de gerar a busca de uma solução, e ainda, eles podem ser experimentais (laboratório aberto e demonstração investigativa) e não experimentais (questões abertas que podem ser introduzidas por textos, imagens, reportagens etc). Em ambos os casos, devem proporcionar o teste de hipóteses, a passagem da manipulação/imaginação para a ação intelectual, a estruturação do pensamento e a apresentação das argumentações socialmente. Ao passar por essas fases os alunos devem variar suas ações, oportunizando a estruturação de regularidades no fenômeno estudado (CARVALHO, 2011a e 2013).

Segundo Carvalho (2013), as seguintes etapas do raciocínio científico estão presentes nas diferentes atividades das SEIs:

- Elaboração e testes de hipóteses, em que o conhecimento prévio é tomado como hipótese de pesquisa na resolução do problema.

- Argumentação.

- Solução do problema, produzindo uma explicação.

- Construção do raciocínio proporcional do tipo "se, então, portanto", o que envolve a seleção e a relação de variáveis relevantes à solução do problema e a necessidade de uma nova palavra/conceito.

Também é importante frisar que as características campo-dependentes da argumentação destacadas no tópico anterior (levantamento e teste de hipóteses e abdução; seriação, classificação e organização de informações; explicação; justificativa, previsão, dedução; indução, raciocínio lógico e proporcional) deverão perpassar em maior ou menor grau por todas essas etapas, sem a necessidade de intervenções extras do professor além das sugeridas no próximo tópico. Por exemplo, ao usar o conhecimento prévio como hipótese de pesquisa, um estudante pode recorrer a um raciocínio abdutivo que tente explicar e justificar a resposta ao problema proposto, ou ainda, ao manipular um aparato experimental, no processo de reconhecimento das variáveis envolvidas no fenômeno, o aluno procure seriar, classificar e organizar as informações observadas com base em seu arcabouço teórico. Para que isso ocorra, é essencial que o professor siga os seguintes passos de gerenciamento da classe (CARVALHO, op. cit.):

- Distribuição do material e proposição do problema pelo professor. 
- Resolução do problema pelos alunos em pequenos grupos, a partir de suas concepções.

- Sistematização coletiva dos conhecimentos elaborados nos grupos, dividida em duas etapas: (1) como ou levantamento dos dados para resolução do problema e (2) porque ou construção de uma justificativa para o fenômeno e da argumentação científica, proporcionando uma explicação causal e a passagem da linguagem cotidiana para a científica.

- Escrever e desenhar, realçando a construção pessoal do conhecimento.

Após a resolução do problema e a construção da explicação deve-se introduzir (1) uma atividade de sistematização, garantindo que todos aprendam o conteúdo, por meio da leitura de um texto (por exemplo, de história da ciência), no qual se pode discutir e retomar as etapas desenvolvidas e o modelo explicativo construído à luz dos novos conceitos. E também, (2) uma atividade de contextualização e aprofundamento do conteúdo, na qual se observa a aplicação do conteúdo em um contexto social. Em ambos os casos, pode-se introduzir questões que estimulem a reflexão sobre a leitura.

\subsection{A sequência de ensino-aprendizagem}

Apresentamos a seguir as atividades propostas para uma sequência de ensino investigativa sobre quantidade de movimento, sua conservação e as leis de Newton. Em cada uma delas, consideramos em sua aplicação os pontos destacados anteriormente sobre as SEIs, tanto em relação às etapas do raciocínio científico quanto do gerenciamento da sala, como forma de desencadear o processo de argumentação com as características apresentadas anteriormente.

Vale destacar que o número de aulas necessárias para a aplicação dependerá das condições particulares de ensino, ou seja, número de alunos por sala, quantidade de aulas disponíveis, e ainda, da escolha do professor em aprofundar certos temas ao sistematizar os conhecimentos em determinada atividade - por exemplo, trazendo uma aula extra de exercícios, realizando cálculos sobre as colisões bidimensionais ou ainda realizando medições nos experimentos propostos.

Geralmente, o trabalho em pequenos grupos requer um tempo considerável dentro do tempo útil disponível nas aulas, isto é, excluindo a mudança de sala, a 
realização da chamada e a sensibilização dos estudantes. Dessa forma, a sistematização das discussões em grande grupo geralmente vem em uma aula posterior.

É importante ressaltar que nos momentos de construção das explicações coletivas de cada aula, o docente deve ficar atento aos problemas que Sandoval e Millwood (2007) sistematizaram nos diferentes trabalhos sobre a argumentação discente, ou seja, as alegações orais ou escritas só serão justificadas quando contestadas.

Dessa forma, destacamos que as intervenções do docente necessitam ser na direção de que os estudantes justifiquem suas alegações, destacando os pontos de desacordo que estão ligados à referida contestação. Ademais, o professor deve ser preciso em suas instruções, solicitando que os alunos justifiquem seus argumentos escritos.

A distribuição de conteúdos da SEI é baseada no livro 1 do Principia (Newton, 2008), ou seja, o autor em sua definição $I I^{17}$ apresenta primeiro o conceito de quantidade de movimento e, ao discuti-lo, introduz implicitamente a noção de conservação:

O movimento do todo é a soma dos movimentos de todas as partes; portanto, em um corpo com o dobro da quantidade, com igual velocidade, o movimento é duplo; com o dobro da velocidade, é quádruplo (NEWTON, 2008, p.40).

Vale destacar que Newton chamava de "movimento" o que hoje é conhecido como quantidade de movimento ou momento linear. Em seguida, nas definições ${ }^{\prime I I}{ }^{18} e$ $I V^{19}$ ele destaca implicitamente o que é conhecido atualmente como as três leis de Newton, e depois, no tópico "Axiomas ou leis de movimento" ele discute as três leis de movimento $^{20}$ em termos da variação dos momentos:

Os corpos maiores dos planetas e cometas, encontrando menos resistência em espaços livres, preservam seus movimentos, tanto progressivo como circular, por um tempo muito maior (p. 53, grifos nossos).

Se uma força gera um movimento, uma força dupla vai gerar um movimento duplo [...] (p. 54, grifos nossos).

\footnotetext{
17 "A quantidade de movimento é a medida do mesmo, obtida conjuntamente a partir da velocidade e da quantidade de matéria” (p.40).

18 "A vis ínsita, ou força inata da matéria, é um poder de resistir, através do qual todo o corpo, no que depende dele, mantém seu estado presente, seja ele de repouso ou de movimento uniforme em linha reta" (p.40).

19 "Uma força imprimida é uma ação exercida sobre um corpo a fim de alterar seu estado, seja repouso, seja de movimento uniforme em linha reta" (p.41)

${ }^{20}$ Lei I: "Todo corpo continua em seu estado de movimento uniforme em uma linha reta, a menos que ele seja forçado a mudar aquele estado por forças imprimidas sobre ele" (p. 53).

Lei II: “A mudança de movimento é proporcional à força motora imprimida, e é produzida na direção da linha reta na qual aquela força é imprimida" (p. 54).

Lei III: "A toda ação há sempre oposta uma reação igual ou, as ações mútuas de dois corpos um sobre o outro são sempre iguais e dirigidas a partes opostas” (p. 54).
} 
Se um corpo se choca com outro, e pela sua força muda o movimento desse, aquele corpo também... sofrerá uma mudança igual no seu próprio movimento, em direção à parte contrária (p. 54, grifos nossos).

Essa abordagem nos parece mais lógica para compreender os movimentos e suas causas, visto que os explica por meio das interações entre corpos através de uma força que provoca uma variação de suas quantidades de movimento. Além disso, a abordagem de Newton faz uma grande sistematização dos trabalhos dos seus antecessores.

Essa sequência de conteúdos também é adotada por outras propostas de ensinoaprendizagem, tal como no trabalho do Grupo de Reelaboração do Ensino de Física (GREF, 2002) e na proposta curricular de São Paulo (BONETTI et. al., 2010). Em outras propostas, apesar de seguirem a 'ordem tradicional' de conteúdos, ao discutir quantidade de movimento e sua conservação, elas apresentam as leis de Newton em termos da conservação da quantidade de movimento, tal como o Projeto Harvard (1978) e o PSSC (1968).

Começamos com uma problematização que visa à construção da noção de quantidade de movimento e sua conservação, e em seguida, introduzimos atividades que estimulam a reflexão sobre as três leis de Newton à luz do princípio de conservação da quantidade de movimento. Abaixo detalhamos cada atividade da SEI em termos dos conteúdos e suas potencialidades para produzir situações argumentativas que envolvam a matemática.

\section{Atividade 1 - Transferindo movimento: o problema do pêndulo de Newton}

Esta atividade tem por objetivo construir uma noção sobre momento linear e sua conservação, por meio de um problema experimental envolvendo a colisão de pêndulos com massas diferentes (tal como Newton fez em seus estudos). Com isso, ela oportuniza a passagem da ação manipulativa para a ação intelectual, na qual os conhecimentos prévios são tomados como hipóteses a serem testadas durante o manuseio do experimento. Nesse processo, os estudantes podem usar seus conhecimentos sobre cinemática como base para as observações das colisões e como suporte para suas alegações e explicações. 
No início da aula o professor introduz o tema, comentando brevemente sobre importância dos movimentos e sobre conhecer suas causas. Deve-se fornecer pêndulos similares ao da figura 13 abaixo, ou seja, com massas diferentes, tal como Newton usou em suas experiências, em que grupos de aproximadamente cinco estudantes possam fazer colisões, tentando responder ao problema ${ }^{21}$ a seguir:

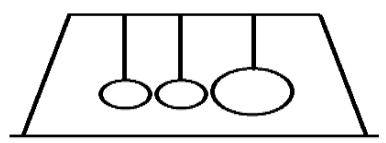

Figura 13: O pêndulo de Newton

Fazendo um pêndulo colidir ${ }^{22}$ com outro, como é possível elevar as bolinhas sempre à mesma altura?

O objetivo do desafio é criar condições para discutir a transferência de movimento entre os pêndulos, emergindo a necessidade do uso da noção de conservação relacionando os conceitos de massa e velocidade. Destacamos ainda que a formalização conceitual não é realizada nessa atividade.

Caso algum grupo apresente dificuldades no processo de solução, o docente pode sugerir questões equivalentes às do $\operatorname{GREF}(2002$, p.61 a 64) elaboradas para um experimento com carrinhos de brinquedo, isto é, pode fazer indagações como o que ocorre:

- ao colidir duas esferas de massas diferentes, com a de maior massa inicialmente parada?

- na situação oposta a anterior, ou melhor, com a de menor massa parada?

- ao colidir duas esferas de massas iguais, estando uma parada?

Os alunos deverão levantar hipóteses e testá-las ao manipular o experimento, situação em que se inicia o processo de argumentação. Resolvido o problema, na aula seguinte $^{23}$, a sala será organizada em forma de círculo e deve-se discutir as respostas obtidas.

O professor deve ficar atento às etapas do raciocínio científico. Dessa forma, primeiramente a discussão necessita focar no 'como' chegou-se a solução, ou seja, é preciso lançar a bola de maior massa de uma altura pequena para que a bolinha de menor massa suba até uma determinada altura e vice-versa. Neste momento, algumas

\footnotetext{
${ }^{21}$ Geralmente faz-se a questão antes de distribuir o material para evitar que os estudantes se dispersem.

${ }^{22}$ É importante que o docente explique o que é colisão para seus alunos, visto que este não é um termo presente em seu vocabulário cotidiano.

${ }^{23} \mathrm{O}$ tempo das atividades dependerá de vários fatores, como o número de alunos e a habilidade de investigação dos mesmos. Pela nossa experiência, os alunos costumam manipular os materiais e discutir os problemas em pequenos grupos em uma aula, logo, deve-se deixar o debate com o grande grupo e a sistematização das respostas para a aula seguinte.
} 
características campo-dependentes da argumentação que devem ter iniciado durante as ações manipulativas poderão reaparecer, tal como seriação, classificação e organização dos dados qualitativos obtidos no experimento e o raciocínio lógico e proporcional.

Em seguida, inicia-se o 'porque' tal fenômeno ocorreu da forma relatada, chegando-se à dependência da massa e da velocidade na colisão (por exemplo, a bola de maior massa, quando elevada a uma pequena altura, ao colidir com a de menor massa, faz essa última subir mais do que a altura inicial da primeira). Isso favorece o surgimento de características argumentativas como explicação, justificativa, raciocínio lógico e proporcional e possivelmente a abduções, já que há necessidade de recorrer uma regra ou conceito que apoie os dados na elaboração de uma conclusão.

A fim de chegar a uma explicação científica para o fenômeno, introduz-se a atividade 2 em uma aula posterior, que pode ser usada para retomar o problema do pêndulo à luz do conceito de conservação da quantidade de movimento e ainda matematizá-lo.

\section{Atividade 2 - O que é quantidade de movimento, afinal? O problema das} colisões

O objetivo desta atividade é sistematizar o conceito de quantidade de movimento e sua conservação (Bellucco, 2012) e conduzir à relação entre ciência, tecnologia e sociedade na SEI, a partir dos conteúdos discutidos no problema experimental.

Iniciamos o primeiro momento com o título e um desenho da situação (figura 14 abaixo), seguidos de três questões semiabertas escritas na lousa ou entregues por escrito:

\section{Momento Linear ou Quantidade de Movimento}

Observe a figura e responda:

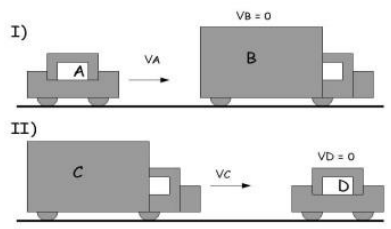

Figura 14: Refletindo sobre a quantidade de movimento e a sua conservação 
a) O que acontecerá com as velocidades de todos os carros depois da colisão, nas situações I e II?

b) O que influencia as velocidades dos carros após as colisões?

c) Podemos dizer que o "movimento" de um carro passa para o outro?

Justifiquem todas as suas respostas.

Durante a discussão em pequenos grupos ${ }^{24}$ e nas etapas do raciocínio científico, esperamos o aparecimento de parte das características campo-dependentes da argumentação científica que destacamos em nossa ferramenta de análise, como levantamento e teste de hipóteses e abdução, seriação, classificação e organização de informações e o raciocínio lógico e proporcional.

Deve-se organizar em seguida o grande grupo para que os estudantes relatem 'como' chegaram às respostas (item 'a', acima), ou seja: o carro A pode se juntar com o $B$ e ambos saírem com uma velocidade mais baixa do que $V_{A}$, e o carro $C$ tem sua velocidade diminuída enquanto o carro $\mathrm{D}$ sai com uma velocidade maior do que $\mathrm{V}_{\mathrm{C}}$. Podem surgir outras hipóteses sobre o freio de mão dos carros, a destruição ou explosão deles, o tipo de chão envolvido, a diminuição da velocidade com a distância, o choque inelástico no qual os carros movimentam-se juntos etc (Bellucco, 2012).

$\mathrm{Na}$ explicação do 'porque', sugerimos que o debate dessas questões seja relacionado às observações da atividade 1 (itens ' $b$ ' e 'c', acima), além disso, é hora de indagar sobre quais condições de contorno devem ser consideradas no problema (choque inelástico, com atrito ou não, explode ou não etc), tal como as hipóteses apresentadas no parágrafo anterior, chegando-se novamente à conclusão de que as colisões dependem tanto da massa quanto da velocidade dos objetos que se chocam. Por fim, introduz-se e matematiza-se os conceitos de quantidade de movimento e sua conservação, sempre fazendo referências aos fenômenos vistos em sala, e ainda, discutindo o carácter vetorial desse conteúdo. O caso bidimensional pode ser relacionado às colisões não frontais que ocorreram durante o experimento dos pêndulos.

Além disso, durante a matematização dos fenômenos, é importante estar atento às ideias intuitivas usadas pelos estudantes, que costumam não diferenciar os conceitos de força, movimento e impulso (CARVALHO, 1989). Logo, o professor precisa debater com cuidado a distinção desses conceitos e 'traduzi-los' nos fenômenos observados durante a sistematização dos conteúdos. Deve-se ainda matematizar a situação da imagem estimando valores para as massas dos carros e suas velocidades iniciais,

\footnotetext{
${ }^{24}$ Muitas vezes a discussão pode ocorrer na aula seguinte, já que os alunos podem levar um tempo considerável da aula para discutir as respostas.
} 
determinando ainda o tipo de colisão (entre perfeitamente elástica até inelástica).

$\mathrm{Na}$ aula seguinte, um texto à escolha do professor (por exemplo, do livro didático disponível na escola) pode ser usado para sistematizar os conhecimentos construídos, sempre usando questões que direcionem a leitura aos aspectos relevantes do tema. Sugerimos o texto da proposta curricular de São Paulo (BONETTI et. al., 2010), reproduzido no anexo I, no qual incluímos um desafio que visa à reflexão sobre as causas dos movimentos por meio do conceito de conservação da quantidade de movimento.

Vale destacar que esse assunto não se esgota aqui, sendo desejável resgatá-lo adiante, com o tema "Energia", no qual se pode usar uma abordagem histórica sobre a "querela das forças vivas" (CARVALHO, op. cit.).

\section{Atividade 3 - Problemas abertos}

Propomos a seguir problemas abertos nos quais o professor pode avaliar o nível de compreensão alcançado sobre o tema, além de possibilitar a recuperação dos alunos que não acompanharam o processo de ensino-aprendizagem:

1 - Qual a máxima quantidade de movimento que você consegue transferir a uma bola durante um pênalti?

2 - Consequentemente, qual é a velocidade adquirida pela bola logo após o chute?

3 - Toda quantidade de movimento do pé é transferida à bola? Explique.

4 - Discuta como a matemática auxilia no entendimento e na resolução das situações descritas nos problemas anteriores.

É importante que a discussão sobre os problemas seja feita em pequenos grupos, por outro lado, a resposta deve ser entregue individualmente, a fim de assegurar a construção pessoal do conhecimento.

Após a entrega, em uma aula seguinte, o docente pode discutir coletivamente as resoluções. A delimitação das variáveis relevantes e a estimativa dos valores aproximados são essenciais para resolução dos problemas abertos e os valores de massa e velocidade deverão ser individuais para cada aluno. Ademais, a compreensão da conservação da quantidade de movimento é fundamental para chegar a uma resposta adequada nos três primeiros problemas. O quarto problema tem por objetivo que o 
estudante reflita sobre a matemática e seu papel no entendimento dos fenômenos e situações físicas.

Para essa tarefa esperamos também que os aspectos campo-dependentes da argumentação sejam marcantes, principalmente o processo de dedução, no qual os alunos precisarão estimar os dados e, a partir da lei geral da conservação da quantidade de movimento, deverão obter resultados específicos/particulares ao responderem às questões.

Outra sugestão para avaliação seria usar o próprio experimento da atividade 1 , para fazer medições por meio de uma filmagem com o auxílio de um celular e o tratamento dos dados obtidos com a ajuda do software tracker $^{25}$ ou outro que faça a mesma função.

\section{Atividade 4 - Conservando os movimentos: as leis de Newton}

Compreendido o que é a conservação da quantidade de movimento, partimos para o estudo das suas consequências, isto é, as leis de Newton.

\section{Atividade 4.1 - Perdidos no Espaço - A primeira lei de Newton}

A primeira lei de Newton exige grande abstração do educando e demanda grande esforço para sua compreensão. É comum ter a noção de que para existir movimento, é imperativo o uso de uma força. Por outro lado, fazer perceber que um objeto pode estar em movimento sem haver uma força o impulsionando é um grande desafio para o professor de física.

Nesta aula, procuramos trazer um tema que apesar de não estar na realidade sensível do aluno, está no seu cotidiano e na sua cultura, seja em filmes, seja na mídia: viagens espaciais. Além disso, ele remete aos exemplos da primeira lei que Newton (2008) discutiu - que foram previamente abordados no começo deste capítulo - sobre o movimento dos planetas. Dessa forma, procuramos estabelecer a relação entre ciência,

\footnotetext{
${ }^{25}$ Disponível em: http://www.cabrillo.edu/ dbrown/tracker/ (acessado em 27 de novembro de 2014).
} 
tecnologia e sociedade, buscando a participação ativa dos estudantes, por meio de um problema que é significativo para eles e que os estimulem a usar seus conhecimentos prévios sobre o assunto.

Introduzimos a aula com a seguinte questão a ser discutida inicialmente em pequenos grupos:

"Para que uma nave no planeta Terra ande 384000 quilômetros (distância da Terra até a Lua) é necessária uma quantidade enorme de combustível (maior que o volume de nossa escola). Sendo assim, como é possivel que uma nave espacial viaje distâncias maiores com quantidade de combustível menor do que essa? O que é preciso para que a nave mude sua direção e sentido no espaço?"

$\mathrm{Na}$ primeira parte desse problema, os estudantes terão que perceber as diferenças entre uma viagem na atmosfera, onde há muito atrito com o ar e uma viagem no espaço sideral em que o atrito é desprezível. Já a segunda questão tem como objetivo promover uma discussão entre os alunos sobre as viagens espaciais em termos da variação da quantidade de movimento.

Esperamos ainda que haja durante as argumentações: levantamento e teste de hipóteses e abdução; seriação, classificação e organização de informações; início da explicação; justificativa, previsão e raciocínio lógico e proporcional.

Durante a discussão no grande grupo, respeitando as etapas do 'como' e 'porque', é preciso destacar que uma mudança espontânea na quantidade de movimento de um objeto, sem a interação com outro corpo, violaria o princípio da conservação da quantidade de movimento.

Por fim, o professor pode definir a primeira lei de Newton discutindo o fenômeno apresentado no problema. É interessante que o texto original seja lido e discutido em sala e que o docente requisite novos exemplos por parte dos alunos, criando condições para o estudo das outras leis de movimento:

Lei I

Todo corpo continua em seu estado de repouso ou de movimento uniforme em uma linha reta, a menos que ele seja forçado a mudar aquele estado por forças imprimidas sobre ele.

Projéteis continuam em seus movimentos, desde que não sejam retardados pela resistência do ar, ou impelidos para baixo pela força da gravidade. Um pião, cujas partes por sua coesão são continuamente afastadas de movimentos retilíneos, não cessa sua rotação a não ser quando retardado pelo ar. Os corpos maiores dos planetas e cometas, encontrando menos resistência em espaços livres, preservam seus movimentos, tanto progressivo como circular, por um tempo muito maior (NEWTON, 2008, p. 54). 


\section{Atividade 4.2 - O que provoca um movimento? Variando a quantidade de}

\section{movimento e a segunda lei de Newton}

Em um momento posterior, procuramos (re)construir o conceito de força com a seguinte atividade:

\section{Variação da Quantidade de Movimento}

Observe a situação a seguir e responda:

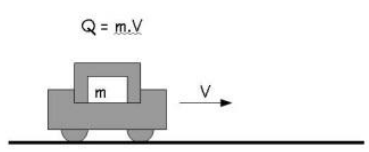

Figura 15: Refletindo sobre a variação da quantidade de movimento

a) O que pode causar a mudança da quantidade de movimento?

b) Qual o símbolo que usamos para representar variação? Como poderíamos fazer para calcular essa variação da quantidade de movimento? Dica: lembrem como fizemos para variação do espaço, tempo e velocidade.

Justifiquem todas as suas respostas.

Para a questão 'a' é necessário que os estudantes discutam sobre a necessidade de uma força para provocar uma variação na velocidade do carro e, consequentemente, na quantidade de movimento. Já a questão 'b', visa estimular uma reflexão sobre a forma matemática de se representar a variação da quantidade de movimento do carro e de outros objetivos, possibilitando a passagem da linguagem oral/escrita para a linguagem formal. Além de favorecer o levantamento e o teste de hipóteses e a abdução; a seriação, a classificação e a organização de informações; a explicação; o raciocínio lógico e o proporcional; essa atividade tem por objetivo usar uma justificativa que se valha de um apelo à analogia ou comparações com outros conhecimentos sobre outras variações estudadas (realizando um raciocínio abdutivo), ao buscar o uso do símbolo $\Delta$ (delta) para representar variações.

Após as discussões em pequenos grupos, na aula seguinte, o docente deve buscar com toda a sala a percepção das condições que fazem alterar a quantidade de movimento do carro e, em seguida, o 'porque' - situação em que se pode mostrar como a equação $(\mathrm{Q}=\mathrm{m}$. $\mathrm{V})$ se relaciona ao fenômeno e vice-versa. $\mathrm{O}$ mesmo pode ser feito ao introduzir as equações usando as expressões para força, impulso ( $\mathrm{I}=\mathrm{F} . \Delta \mathrm{t})$ e variação da 
quantidade de movimento, sempre se referindo à situação apresentada, criando condições para a introdução da segunda lei de Newton $(F=\Delta Q / \Delta t)$ e para a diferenciação desses conceitos. Deve-se ainda retomar a discussão sobre impulso, movimento e força iniciada no final da atividade 2 , sem esquecer de destacar o caráter vetorial dessas grandezas.

É importante que o professor destaque que essas equações são uma forma moderna de representar os fenômenos e que foram os cientistas contemporâneos a Newton, tal como Euler, que as escreveram baseando-se em seu trabalho (CARVALHO, 1989). Para auxiliar o debate, deve-se apresentar a formulação original newtoniana solicitando novos exemplos:

\section{Lei II}

A mudança de movimento é proporcional à força motora imprimida, e é produzida na direção da linha reta na qual aquela força é imprimida.

Se qualquer força gera um movimento, uma força dupla vai gerar um movimento duplo, uma força tripla, um movimento triplo, seja aquela força imprimida uma única vez, ou gradual e sucessivamente. Esse movimento (sendo sempre orientado na mesma direção da força geradora), caso o corpo se mova antes, é adicionado ou subtraído do primeiro movimento, dependendo se eles cooperam na mesma direção ou se não são diretamente contrários, um ao outro, ou obliquamente combinados, quando oblíquos, de modo a produzir um novo movimento composto a partir da determinação de ambos (NEWTON, 2008, p. 55).

\section{Atividade 4.3 - Interagindo e reagindo: a terceira lei de Newton}

Nesta aula, o professor deve montar o experimento a seguir com uma prancha de madeira (dimensões de $15 \mathrm{~cm} \times 10 \mathrm{~cm}$ ), três preguinhos ou parafusos, elástico, vela ou isqueiro, canudos ou lápis cilíndricos e uma bola de gude:

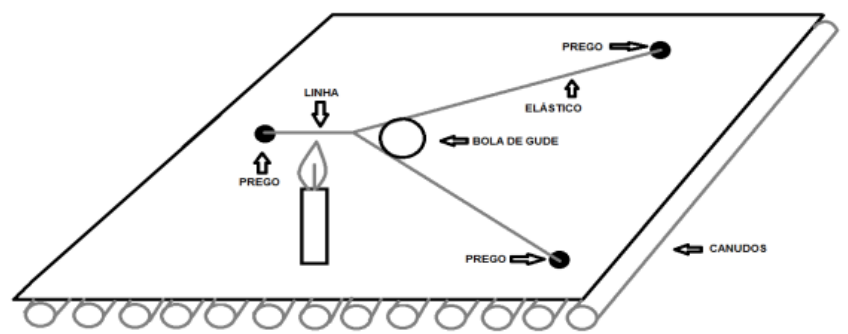

Figura 16: Demonstração investigativa da Ação e Reação

Deve-se realizar a demonstração investigativa com a sala disposta em círculo e, antes de queimar a linha, o professor irá propor o seguinte problema experimental: " $o$ 
que irá acontecer quando o fio arrebentar?". Depois que as ideias/concepções dos estudantes forem expressas e organizadas na lousa, pode-se realizar o experimento ${ }^{26}$.

A partir da visualização do fenômeno, inicia-se a etapa da construção da explicação em um grande grupo, na qual o docente deve requisitar esclarecimentos sobre o ocorrido, sem avaliar, procurando com questionamentos intermediários estimular posteriormente a construção de uma explicação do 'porque' a prancha recua enquanto a bola avança, a partir dos diferentes pontos de vista. Neste momento, pode-se solicitar ainda que os discentes relacionem o fenômeno ao que eles sabem sobre a quantidade de movimento e sua conservação.

A partir disso, pode-se introduzir a lei da Ação e Reação, enfatizando a questão da necessidade da interação entre corpos para iniciar um movimento, ou seja, a variação da quantidade de movimento de um corpo não acontece espontaneamente, é preciso que haja uma interação com outro objeto de forma que haja a conservação da quantidade de movimento deles.

Isto propicia também a retomada do conceito de inércia - não existe uma variação espontânea da quantidade de movimento, sempre é necessária uma interação através de uma força - e o tratamento de exemplos do cotidiano como o lançamento de foguetes, andar etc, além de favorecer a descrição do experimento a partir da segunda lei de Newton. Assim, quando o arranjo exerce uma força na bolinha variando sua quantidade de movimento, ela faz o mesmo no arranjo. $\mathrm{O}$ docente pode solicitar um texto escrito explicando o experimento para a aula seguinte, além de trazer e discutir a formulação original de Isaac Newton solicitando novos exemplos:

Lei III
A toda ação há sempre oposta uma reação igual ou, as ações mútuas de dois
corpos um sobre o outro são sempre iguais e dirigidas a partes opostas.
Seja o que for que puxe ou empurre alguma coisa, é da mesma forma, puxado
ou empurrado por ela. Se você empurra uma pedra com seu dedo, o dedo é
também empurrado pela pedra. Se um cavalo puxa uma pedra amarrada a
uma corda, o cavalo (se posso dizer assim) vai ser igualmente puxado de
volta na direção da pedra, pois a corda distendida, pela mesma tendência a
relaxar ou distorcer-se, puxará o cavalo, e obstruirá o progresso de um tanto
quanto promove o do outro. Se um corpo se choca com o outro, e pela sua
força muda o movimento desse, aquele corpo também (por causa da
igualdade da pressão mútua) sofrerá uma mudança igual no seu próprio
movimento, em direção à parte contrária. As mudanças feitas por essa ação
são iguais não nas velocidades, mas nos movimentos dos corpos; quer dizer,
se os corpos não forem obstruídos por quaisquer outros impedimentos. Pois,
porque os movimentos são igualmente alterados, as mudanças de velocidades

${ }^{26}$ É importante que o experimento não esteja em uma superfície muito lisa, para que os lápis rolem adequadamente. Cinco ou seis lápis separados por uma distância de aproximadamente $10 \mathrm{~cm}$ são o ideal para realizar a demonstração. 
feitas em direções a partes contrárias são inversamente proporcionais aos corpos. Essa lei também ocorre em atrações[...] (NEWTON, 2008, p. 55).

Por fim, o professor pode equacionar o problema experimental por meio do problema aberto "quais são as forças que atuam na bola e na prancha após queimar a linha? Por que a velocidade de ambos é diferente?", chamando a atenção para a diferença entre as massas dos objetos, ou seja, como a força tem a mesma intensidade e as massas dos objetivos são diferentes, a aceleração de cada um deles deve ser diferente (como a bolinha tem menor massa, sua aceleração é maior que a do arranjo).

Nessa atividade espera-se o aparecimento das seguintes características da argumentação científica: levantamento e teste de hipóteses e abdução; seriação, classificação e organização de informações; explicação; justificativa com uso de definição, apelo à analogia ou comparações; previsão, raciocínio lógico e proporcional.

\section{Atividade 5 - Avaliando}

Para avaliar a compreensão dos alunos sobre o tema propomos os seguintes problemas abertos:

1 - Ao ver Lois Lane ser arremessada do alto de um prédio, o Super-Homem a agarra na tentativa de salvá-la. Ela sobrevive? O que ele deveria fazer para que ela sobreviva? Justifique sua resposta por meio da escrita e da matemática.

2 - Qual é a velocidade de recuo da Terra quando você salta sobre ela? Discuta o valor encontrado.

3 - Como você avalia o uso da matemática nesses problemas em relação à atividade de avaliação anterior?

Enfatizamos aqui a importância da etapa de discussão em pequenos grupos, porém, há também a necessidade de uma produção escrita individual a fỉm de realçar a construção pessoal do conhecimento, logo, cada aluno deve entregar uma folha com a sua resposta. $\mathrm{Na}$ aula posterior o professor deve discutir as respostas e uma possível solução para os problemas.

Nas respostas, uma das questões fundamentais é o tempo de frenagem que o Super-Homem deve imprimir na Lois Lane, ou melhor, a força na equação $F=\Delta Q / \Delta t$ será muito maior se o tempo for muito pequeno. Sendo assim, é necessário um tempo maior para que a força aplicada pelo herói não machuque a moça. Na segunda questão é 
interessante verificar matematicamente que a ação do pé é insignificante dada a massa gigantesca da Terra, sendo o seu recuo infinitesimal; todavia, a reação é considerável dada a massa da pessoa. Como na avaliação anterior, o último problema tem por objetivo que o estudante reflita sobre a matemática e seu papel no entendimento dos fenômenos e situações físicas relativas às leis de Newton. Nos dois primeiros problemas os processos dedutivos são importantes, já que serão extraídos resultados particulares de leis gerais.

A seguir discutimos a metodologia de pesquisa para coleta de dados, a começar da filmagem da sequência de ensino investigativa apresentada, que auxilie a responder às questões de pesquisa propostas. 


\section{Metodologia de Pesquisa}

Neste capítulo, discutimos a metodologia de pesquisa deste trabalho. Optamos por uma abordagem qualitativa, tal como pôde ser observado na construção teórica desenvolvida ao longo desta tese. Nossa intenção é desenvolver um estudo sobre o processo de ensino-aprendizagem, ao observar a argumentação dos estudantes usando conteúdos matemáticos na resolução de problemas.

Portanto, os métodos quantitativos não dão o suporte necessário para interpretar as peculiaridades dessa situação - isso se dá, pois nesse caso não é possível definir variáveis objetivas e uma escala clara de valores para medição dessas variáveis.

Dessa maneira, os métodos qualitativos, em um sentido interpretativo (ERICKSON, 1998), melhor se enquadram nesta pesquisa, já que favorecem a observação e elucidação dos significados que os estudantes atribuem às situações de sala de aula.

Especificamente, a presente pesquisa constitui um estudo de caso, já que visa o estudo e a clarificação de uma situação peculiar, de contexto bem definido e situado no espaço e tempo (CHIZZOTTI, 2011). Em nosso trabalho, essa afirmação pode ser entendida como a pesquisa e a compreensão sobre como os conteúdos matemáticos são demandados pelos alunos do primeiro ano do ensino médio, na resolução de problemas ao longo de uma sequência de ensino investigativa, buscando identificar os obstáculos de aprendizagem dos conteúdos de física.

\subsection{Objetivos da pesquisa}

Buscamos ao longo deste trabalho construir uma ferramenta para o estudo da argumentação matemática dos estudantes em aulas investigativas de física, visando responder as seguintes questões:

Como o conhecimento matemático é demandado na construção dos argumentos científicos dos estudantes em aulas investigativas de física?

Quais são as dificuldades enfrentadas pelos alunos ao longo desse processo? 
Como a linguagem matemática torna-se necessária para a construção dos significados científicos?

Como se dá a apropriação desse conhecimento matemático?

Nosso objetivo geral com essas questões é compreender melhor os processos de ensino e aprendizagem específicos da disciplina de física ou as dinâmicas envolvidas na enculturação científica dos estudantes. Em termos de objetivos específicos, buscamos compreender de forma mais profunda: os mecanismos que levam os estudantes do ensino médio a se apropriarem da linguagem matemática para interpretar os fenômenos físicos e os obstáculos que se apresentam nesse processo.

\subsection{Definindo o objeto de pesquisa}

Para responder às questões propostas, desenvolvemos uma sequência didática investigativa (SEI), que possibilita estudar a argumentação em aulas de física e seus aspectos matemáticos. A análise da aplicação das aulas de resolução de problemas dessa sequência de ensino constitui o objeto de pesquisa, em que se enquadra a presente investigação. Vale destacar que alguns problemas extras, que serão discutidos no tópico "Análise dos dados", foram criados e adicionados pelo professor que colaborou com a pesquisa no decorrer da regência das aulas.

Antes de ministrar SEI para a turma do ensino médio, fizemos uma aplicação piloto da mesma em uma turma do primeiro ano de graduação em física da Universidade do Estado de Santa Catarina (UDESC), com o objetivo de validá-la. A partir desse trabalho, verificamos que as aulas propiciam os aspectos matemáticos da argumentação delimitados teoricamente (a transcrição de uma dessas aulas, com as características campo-dependentes da argumentação identificadas, encontra-se no anexo II) - garantindo assim a confiabilidade dos dados (YIN, 2010), uma vez que houveram resultados similares na aplicação piloto da sequência de ensino e na aplicação para a turma de análise da tese.

Esse teste inicial da sequência de ensino, também serviu como forma de teste do equipamento de gravação, visto que foi necessária a construção de um aparato específico para registrar com eficiência o trabalho em grupo (conforme veremos 
adiante), que faz parte da dinâmica dessas aulas de resolução de problemas, que compõem o objeto de pesquisa.

Ao verificar o potencial dessa SEI em termos do desenvolvimento das características argumentativas delineadas teoricamente e ao ajustar o aparato de gravação, ela foi ministrada para uma turma do primeiro ano do ensino médio.

\subsection{Delimitando o caso}

Conforme relatado anteriormente, o presente estudo de caso trata de compreender a apropriação, com os obstáculos que se apresentam, dos conteúdos de física e sua representação matemática, por estudantes do ensino médio ao resolverem problemas em uma SEI.

Trata-se, portanto, de um caso único (YIN, 2010) por ser um caso:

- Crítico, no qual por meio de uma revisão densa, delimitou-se um conjunto de proposições - no caso as características campodependentes da argumentação na física - que podem ser usadas para confirmar ou ampliar a teoria;

- Único, que representa uma situação extrema ou peculiar, na qual não se encontra normalmente. $\mathrm{Na}$ presente pesquisa seria a resolução de problemas abertos em uma sequência de ensino delineada para que os alunos argumentem matematicamente, ou seja, uma situação que não costuma ocorrer nas salas de aula do ensino médio (extrema e peculiar).

- Revelador, em que se tem uma ocasião oportuna para investigar uma situação previamente inacessível ao pesquisador - a saber, não se encontram sequências de ensino investigativas sendo ministradas regularmente para alunos do ensino médio.

Somando-se à essas justificativas, encontramos razões pragmáticas, ou melhor, o tempo para se realizar essas pesquisas é limitado - uma mesma SEI não pode ser aplicada no mesmo ano em decorrência do tempo escolar, o que dificulta bastante a multiplicação de casos. Além disso, é necessário realizar uma formação continuada com 
o professor que irá ministrar a SEI, pois quando o pesquisador assume o papel do docente, geralmente a análise é carregada de justificativas dos seus comportamentos, que enviesam a análise, desconsiderando seus referenciais teóricos (CARVALHO, 2011).

A seguir descrevemos o local e os participantes do presente estudo de caso.

\subsubsection{A Escola, o professor e os alunos}

O caso analisado foi desenvolvido de março a agosto de 2013, em uma escola estadual de Santa Catarina, localizada no município de Garuva, que atende aos níveis de ensino fundamental e médio, totalizando em torno de 1000 alunos.

O público desse estabelecimento engloba majoritariamente alunos de classe baixa de regiões urbanas e rurais dos arredores da cidade e de cidades vizinhas e, ainda, alguns alunos indígenas residentes em uma aldeia localizada nas imediações da comunidade.

O professor colaborador é licenciado em física e possui quinze anos de experiência no magistério. Sendo um profissional que trabalha com metodologias diferenciadas, tais como uso de problemas abertos e portfólios de aprendizagem. Além disso, ele foi bastante receptivo à discussão sobre o trabalho a ser desenvolvido, realizando reuniões periódicas com o pesquisador antes da regência das aulas, nas quais eram debatidas as atividades da SEI e a metodologia envolvida. Durante a aplicação das aulas, continuamos os encontros de forma um pouco mais espaçada, nos quais debatemos novas atividades e as videogravações das aulas, em termos das ações do professor que levaram os alunos a argumentarem.

Sobre a forma de trabalho do professor colaborador, é relevante destacar que ele costuma ensinar algumas etapas que os alunos devem seguir na resolução dos problemas abertos, a saber: análise do problema, hipóteses, estratégia de resolução, aplicação da estratégia e análise dos resultados.

A SEI foi ministrada em uma turma de primeiro ano do ensino médio, que contava com aulas duplas. A primeira e a segunda atividades foram realizadas no pátio da escola, onde existem amplas bancadas que facilitaram o trabalho em grupo com os pêndulos. As demais atividades foram desenvolvidas na sala de aula dessa turma, que 
possui a disposição mais comum das carteiras - alinhadas em filas voltadas para frente - e uma lousa verde. No decorrer do semestre o horário da turma sofreu algumas alterações, sendo as aulas alocadas em dois dias da semana.

\subsection{Registro dos dados potenciais}

Tanto na fase piloto de aplicação da SEI quanto na segunda fase, os dados potenciais foram coletados a partir das videogravações das aulas, permitindo assistir várias vezes as situações de ensino e extrair novos aspectos cada vez que elas foram assistidas (CARVALHO, 2011b). A análise desses materiais por meio do referencial teórico adotado constitui os dados de pesquisa. Destacamos que anteriormente à gravação em vídeo, solicitamos uma autorização por escrito para uso do material coletado com fins didáticos e de pesquisa (anexo III).

Nesse processo, uma dificuldade adicional nos foi imposta devido às questões de pesquisa, que envolvem "como se aprende" (CARVALHO, op. cit.), ou seja, a investigação tem por objetivo estudar os processos que conduzem à aprendizagem, o que envolveu a gravação de grupos de alunos discutindo e argumentando sobre os fenômenos e conceitos científicos, durante as resoluções de problemas. Por outro lado, as filmadoras à disposição no mercado possuem microfones embutidos que captam o áudio com baixa qualidade e também muitos ruídos externos, o que dificulta muito a análise dos vídeos nesses momentos de trabalho coletivo. Isso nos levou a buscar uma forma específica de gravação do áudio, que ajudou a superar essa dificuldade metodológica relatada por Sampson et. al. (2012) e Jiménez-Aleixandre e Bustamante (2003), para as pesquisas que envolvem a análise do discurso.

Primeiramente planejamos registrar o áudio com um gravador digital comum, que é adicionado ao vídeo por meio de um software de edição, como o Sony Vegas algo que já vem sendo realizado por alguns pesquisadores da área de ensino de ciências. Mesmo nesses casos muita informação é perdida, dessa forma, adquirimos um gravador semiprofissional Zoom H4n, que possui dois microfones embutidos, captando o áudio com eficiência em ângulos de $90^{\circ}$ a $120^{\circ}$.

Depois, como a intenção era gravar grupos organizados em círculos, para evitar a perda de informações com as angulações supracitadas, desenvolvemos um microfone 
do tipo $\mathrm{PZM}^{27}$ caseiro, que registra uma "zona de pressão" ao seu redor com eficácia, ou melhor, captando o áudio com qualidade em uma configuração esférica de determinado raio e registrando com menor eficiência o som fora dessa região. Desenvolvemos também um pré-amplificador de baixo custo que aumenta a intensidade do sinal elétrico gerado por esse microfone, melhorando a qualidade da captação do som. A descrição de como construir o microfone, o pré-amplificador e sua fonte de alimentação encontra-se no anexo IV.

Assim, o microfone foi ligado ao pré-amplificador e este ao gravador digital (ele também poderia ser ligado diretamente na filmadora, caso esta tenha entrada para microfone externo), possibilitando uma gravação eficiente do trabalho dos alunos e, surpreendentemente, dos momentos de fala do professor, sem o ruído de fundo típico dessas gravações. Mesmo nas gravações no pátio, onde ocorreu uma forte ventania, ou seja, algo que costuma estragar completamente o áudio das videogravações, não houve problema com o áudio e a captação das discussões em grupos.

Ainda nos registros da turma do ensino médio foram usados dois microfones PZM simultaneamente para registrar o som de um grupo, uma vez que o gravador dispunha dessa possibilidade, melhorando significativamente a captação do áudio.

\subsection{Organização da análise}

A análise foi dividida em episódios, ou seja, períodos da situação de ensino em que se torna claro o que o pesquisador quer investigar (CARVALHO, 2011b). No nosso caso, procuramos os momentos em que a linguagem matemática e as demais apoiam o processo de argumentação científica dos estudantes, nas resoluções de problemas, de forma que apareçam as características campo-dependentes dessa situação que destacamos anteriormente.

Além disso, cada episódio foi dividido em cenas indicando o tempo de cada uma delas, para facilitar a visualização da discussão dos dados.

\footnotetext{
${ }^{27}$ Pressure Zone Microphone.
} 


\subsubsection{Dados da pesquisa}

A fonte potencial de dados é constituída pela transcrição das aulas videogravadas, que foi realizada utilizando o padrão proposto por Preti (1997), com algumas adaptações (anexo V). Ademais, como vemos abaixo, reproduzimos também os gestos, desenhos e demais linguagens usadas ao longo das aulas, além de informações sobre ações e comportamentos, posto que nossas atenções dirigem-se à argumentação multimodal. Substituímos os nomes dos estudantes pelas representações A1, A2, A3 etc e do professor por P, a fim de preservar as suas identidades.

Os dados da pesquisa são constituídos por esse material interseccionado com a teoria (Erickson, 1998; Carvalho, 2011b), ou seja, é a partir do diálogo com os referenciais teóricos que as informações transcritas se transformaram nos dados da investigação.

Isso serviu como um "filtro" para demarcação dos episódios de ensino. Logo, como o foco é na argumentação científica dos estudantes, em geral, os momentos em que o professor direciona sua fala para toda a turma, sem interagir diretamente com os alunos, são excluídos da análise.

Abaixo temos um exemplo de transcrição de uma das cenas do primeiro episódio de ensino, que é apresentada em um quadro contendo:

- Uma coluna indicando o intervalo de tempo da cena apresentada;

- Outra com a transcrição da linguagem oral e a descrição das ações e das outras linguagens entre parênteses duplos;

- Uma terceira coluna que apresenta as etapas do ciclo argumentativo e as características campo-dependentes da argumentação identificadas na cena. 


\begin{tabular}{|c|c|c|}
\hline $\begin{array}{r}\text { Tempo inicial } \\
\text { e final da cena }\end{array}$ & Transcrição, Descrição das ações e linguagens & Ciclo Argumentativo \\
\hline \multirow[t]{3}{*}{$\begin{array}{l}01: 11: 00- \\
01: 11: 20\end{array}$} & \multirow{3}{*}{$\begin{array}{l}\text { A2: O professor a gente está tentando pensar... } \\
\text { A1: A gente tem que dividir, né? } \\
\text { A2: Já pensou aí como se faz? ((alunos escrevem no } \\
\text { caderno)). } \\
\text { A1: Dividi né? } \\
\text { A2: Cinco dividido por... /// A5: Os dois tem mesma... } \\
\text { A6: Cinco } \\
\text { A5: Vinte e cinco divido por cinco é cinco. } \\
\text { A1: Tem que divi/... tem que soma/... tem que fazer a } \\
\text { conta... } \\
\text { A3: Tem que fazer aquela V1... } \\
\text { A6: Então } \\
\text { A3: Então... é aquilo que tem no caderno... pesquisa no } \\
\text { caderno que você (acha)... }\end{array}$} & $\begin{array}{l}\text { Definição de variáveis } \\
\text { Explicação }\end{array}$ \\
\hline & & Argumentação \\
\hline & & $\begin{array}{c}\text { Abdução } \\
\text { Dedução } \\
\text { Justificativa }\end{array}$ \\
\hline
\end{tabular}

Quadro 9: Cena 1.5

Vale destacar que na cena acima, apesar da linguagem algébrica não estar descrita entre parênteses duplos, ela é marcante para discussão, já que os estudantes discutem as operações matemáticas e os valores relevantes para a dedução do resultado. Ou seja, ela é o objeto de discussão e está explícita na linguagem oral.

\subsubsection{Ferramenta para análise dos dados}

A ferramenta apresentada no capítulo 4 foi usada no processo de análise dos dados. Conforme argumentamos, o software Videograph facilita a visualização das categorias definidas na revisão bibliográfica ao longo das videogravações, com as transcrições. Dessa forma, assim como Carvalho (2011) argumenta que o vídeo implica em uma mudança no paradigma educacional, possibilitando “[...] ultrapassar os limites do observável em relação aos processos de ensino e aprendizagem” (p. 32), o software amplia ainda mais a visão do pesquisador, ao promover a visualização e a relação dos múltiplos referenciais em uma linha temporal, tal como pode ser observado nas figuras abaixo. 


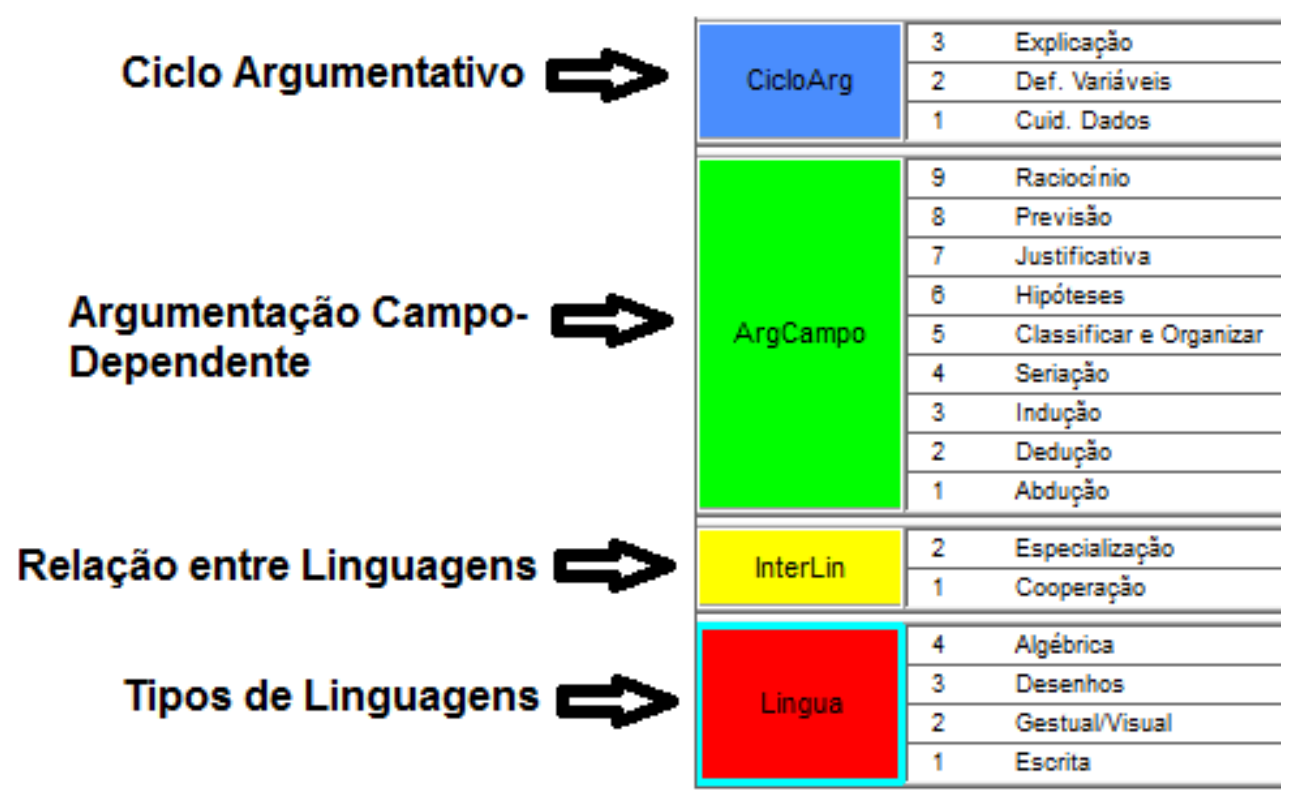

Figura 17: Categorias de análise da argumentação matemática no software Videograph

Acima verificamos como as categorias e as subcategorias da revisão bibliográfica podem ser organizadas no software Videograph. Cada uma das categorias (CicloArg, ArgCampo, InterLin e Lingua) são divididas em sublinhas, nas quais são distribuídas suas subcategorias.

Abaixo observamos o gráfico temporal produzido em um dos episódios de ensino, no qual as categorias podem ser trianguladas com o vídeo e as transcrições, resultando em uma interpretação da situação em direção à construção de uma resposta para as questões de pesquisa.

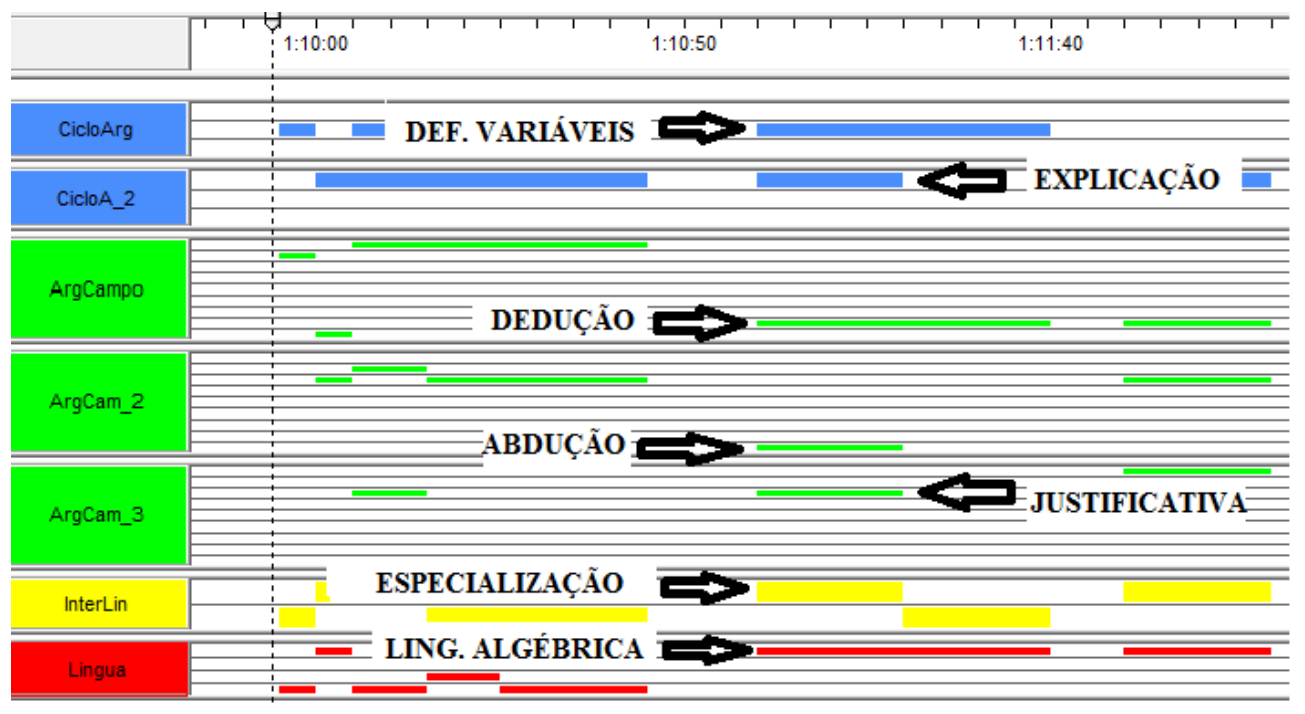

Figura 18: Ocorrência das categorias de pesquisa no gráfico do Videograph para o episódio 1. 
Vemos na figura 18 que a numeração das subcategorias não aparece no gráfico temporal, então, é necessário contar as sublinhas de baixo para cima, a partir de cada categoria, para identificá-las. Quando há simultaneidade de duas subcategorias, a linha correspondente é duplicada no gráfico - tal como ocorre com a argumentação campodependente em verde. Nesse caso, ocorre uma dedução (segunda sublinha em ArgCampo) simultaneamente com uma $a b d u c ̧ a ̃ o$ (primeira sublinha de baixo para cima em "ArgCam_2") e uma justificativa (sétima sublinha de baixo para cima em “ArgCam_3”). Além disso, verificamos que nesse estrato do episódio a linguagem algébrica (quarta sublinha de baixo para cima em "Língua") especializa esses significados (segunda sublinha de baixo para cima em "InterLin"). E ainda, que as etapas de explicação (segunda sublinha de baixo para cima em "CicloArg”) e definição das variáveis relevantes ao problema (terceira sublinha de baixo para cima em "CicloA_2") ocorrem concomitantemente nesse mesmo período da aula.

A estruturação da análise favorece dessa forma também a discussão da qualidade da argumentação, isto é, a forma e os conteúdos para coordenar alegação e evidências.

Descrevemos abaixo as categorias de análise da nossa ferramenta:

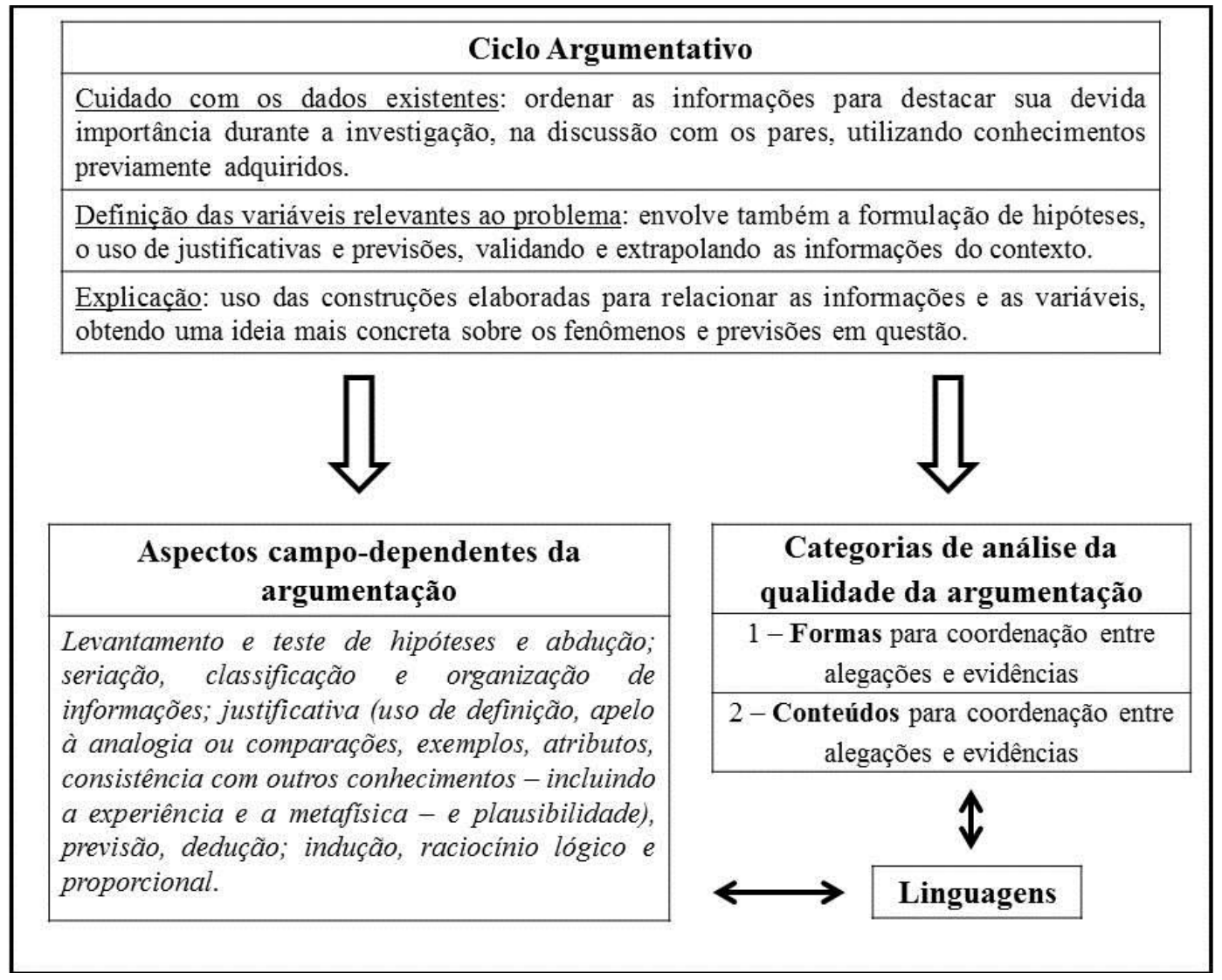

Figura 19: Análise da argumentação campo-dependente 


\begin{tabular}{|c|c|}
\hline $\begin{array}{l}\text { Características Campo- } \\
\text { Dependentes }\end{array}$ & Descrição \\
\hline Seriação & $\begin{array}{l}\text { Lista de dados trabalhados ou para trabalhar. Estabelece as bases para } \\
\text { a investigação. }\end{array}$ \\
\hline $\begin{array}{l}\text { Classificação e organização de } \\
\text { informações }\end{array}$ & $\begin{array}{l}\text { Trata-se da busca por similaridades em um arranjo de informações, } \\
\text { podendo criar-se hierarquias entre elas. Envolve também o processo } \\
\text { de estimativas. }\end{array}$ \\
\hline $\begin{array}{l}\text { Levantamento e teste de } \\
\text { hipóteses }\end{array}$ & Suposições sobre um tema em estudo, que são colocadas à prova. \\
\hline Justificativa & $\begin{array}{l}\text { Cria a base para sustentar uma alegação que leva a uma conclusão, } \\
\text { pode ser: uso de definição, apelo à analogia ou comparações, } \\
\text { exemplos, atributos, consistência com outros conhecimentos - } \\
\text { incluindo a experiência e a metafísica - e plausibilidade. }\end{array}$ \\
\hline Explicação & Relaciona informações e hipóteses, geralmente após a justificativa. \\
\hline Previsão & Antecipar ações e/ou fenômenos relacionando acontecimentos. \\
\hline Abdução & $\begin{array}{l}\text { Uso de uma hipótese/regra como justificativa para explicar um } \\
\text { conhecimento novo, de forma a criar dados para amparar uma } \\
\text { conclusão. }\end{array}$ \\
\hline Dedução & Raciocínio do geral para o particular. \\
\hline Indução & Conclusão apoiada em uma inferência, das partes para o todo. \\
\hline $\begin{array}{l}\text { Raciocínio lógico e } \\
\text { proporcional }\end{array}$ & $\begin{array}{c}\text { A forma como o pensamento é estruturado e como se relacionam as } \\
\text { variáveis no mesmo. }\end{array}$ \\
\hline
\end{tabular}

Quadro 10: Características da argumentação-campo dependente.

\subsubsection{Apresentação da análise}

$\mathrm{Na}$ análise dos dados, apresentamos uma breve introdução sobre o episódio seguida de sua transcrição, que é dividida em cenas, que são comentadas à luz das categorias apresentadas.

Cada cena é apresentada por meio de um quadro, no qual há uma coluna indicando o tempo; outra com a transcrição das falas, da descrição das ações e das outras linguagens; e, por último, uma coluna com as categorias de análise ciclo argumentativo e argumentação: 


\begin{tabular}{|c|c|c|}
\hline $\begin{array}{l}\text { Tempo inicial } \\
\text { e final da cena }\end{array}$ & Transcrição, Descrição das ações e linguagens & Ciclo Argumentativo \\
\hline \multirow[t]{3}{*}{$\begin{array}{l}01: 11: 50- \\
01: 12: 10\end{array}$} & \multirow{3}{*}{$\begin{array}{l}\text { P: Vamos lá então? } \\
\text { A2: Aí dá cinco... dá a mesma coisa... } \\
\text { P: Qual é a quantidade de movimento maior? } \\
\text { A6: Cinco } \\
\text { Vários alunos: São iguais. } \\
\text { Aluno magro de boné: Os dois vão o mesmo número } \\
\text { de movimento ((inaudível)). } \\
\text { Elis: A massa de um é maior... mas a velocidade do } \\
\text { outro é maior... }\end{array}$} & $\begin{array}{c}\text { Definição de variáveis } \\
\text { Explicação }\end{array}$ \\
\hline & & Argumentação \\
\hline & & $\begin{array}{c}\text { Dedução } \\
\text { Justificativa } \\
\text { Raciocínio lógico e } \\
\text { proporcional }\end{array}$ \\
\hline
\end{tabular}

Comentamos cada cena a partir das categorias sobre a argumentação encontradas e, depois, sistematizamos todo o episódio por meio do gráfico temporal construído no Videograph, debatendo também a sua qualidade argumentativa, em termos de sua forma e seu conteúdo, o que possibilita uma discussão sobre o conteúdo matemático demandado nas argumentações dos estudantes.

Apresentamos no tópico seguinte seis episódios de ensino (a transcrição completa desses episódios encontra-se no anexo VI), que foram mapeados no decorrer das aulas referentes aos conteúdos de quantidade de movimento e sua conservação da SEI, a saber:

\begin{tabular}{|c|c|c|}
\hline $\begin{array}{l}\text { Aulas - } \\
\text { Datas }\end{array}$ & Atividades & Episódios \\
\hline $\begin{array}{c}1 \text { e } 2- \\
03 / 05 / 2013\end{array}$ & $\begin{array}{l}\text { Pêndulo de Newton, questões abertas e } \\
\text { problema fechado }\end{array}$ & $\begin{array}{c}1-\text { Quem tem maior } \\
\text { quantidade de movimento? } \\
\text { Um problema fechado }\end{array}$ \\
\hline \multirow{2}{*}{$\begin{array}{c}3 \text { e } 4- \\
10 / 05 / 2013\end{array}$} & \multirow{2}{*}{$\begin{array}{l}\text { Leitura e discussão do texto de sistematização, } \\
\text { resolução de exemplo de problema aberto pelo } \\
\text { professor e resolução dos problemas da SEI }\end{array}$} & $\begin{array}{l}2 \text { - Problemas abertos } \\
\text { (atividade } 3 \text { da SEI) }\end{array}$ \\
\hline & & $\begin{array}{c}3 \text { - Discussão coletiva sobre } \\
\text { os problemas abertos }\end{array}$ \\
\hline $\begin{array}{c}5 \text { e } 6- \\
24 / 05 / 2013\end{array}$ & $\begin{array}{l}\text { Continuação da resolução dos problemas } \\
\text { abertos da SEI }\end{array}$ & Falha na captação do áudio. \\
\hline \multirow{3}{*}{$\begin{array}{c}7 \text { e } 8- \\
07 / 06 / 2013\end{array}$} & \multirow{3}{*}{ Problemas abertos sobre colisões inelásticas } & $\begin{array}{c}4 \text { - Problemas abertos sobre } \\
\text { colisões inelásticas }\end{array}$ \\
\hline & & $\begin{array}{l}5 \text { - Interpretação dos } \\
\text { resultados matemáticos }\end{array}$ \\
\hline & & $\begin{array}{c}6-\text { O problema aberto dos } \\
\text { astronautas }\end{array}$ \\
\hline
\end{tabular}

Quadro 12: Episódios mapeados na SEI envolvendo quantidade de movimento e sua conservação 


\section{Análise dos dados}

Apresentamos a seguir a análise minuciosa dos seis episódios de ensino mapeados ao longo da SEI sobre quantidade de movimento e sua conservação.

Episódio 1 - Quem tem maior quantidade de movimento? Um problema fechado

Esse episódio ocorreu no final da primeira aula dupla da SEI, após a resolução do problema experimental com os pêndulos (atividade 1) e das questões abertas envolvendo as colisões de automóveis e caminhões (atividade 2). O professor sistematizou o conceito de quantidade de movimento e forneceu um problema fechado com dados numéricos para que os grupos de alunos resolvessem.

As atividades foram desenvolvidas no pátio, nas bancadas do refeitório da escola:

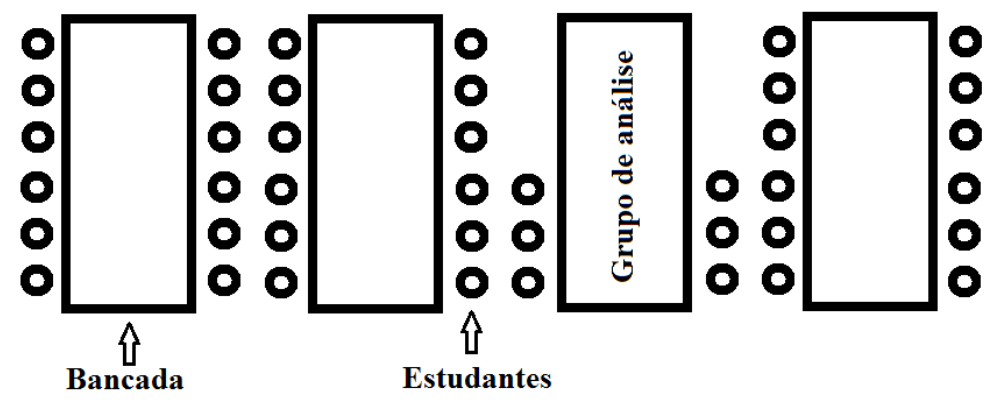

Figura 20: visão geral da turma

Os alunos do grupo de análise foram nomeados da seguinte forma:

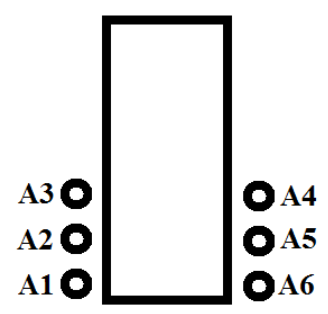

Figura 21: grupo de análise

Apresentamos a seguir a discussão desse grupo sobre a resolução do problema: 


\begin{tabular}{|c|c|}
\hline $\begin{array}{l}\text { Tempo inicial e } \\
\text { final da cena }\end{array}$ & Transcrição, Descrição das ações e linguagens \\
\hline 01:04:40-1:09:55 & $\begin{array}{l}\text { P: Agora para dizer que não fizemos conta em física... né? Tem que ter uma } \\
\text { continha... ((alunos debocham)) então coloquem aí exemplo... agora vamos ao } \\
\text { nosso imaginário.... do lado esquerdo vocês vão desenhar um caminhão igual } \\
\text { este da folhinha((sobre a atividade } 2)) \ldots \text { ((alunos perguntam se é para fazer a } \\
\text { lápis e comentam que não sabem desenhar)) coloquem aí a massa do caminhão } \\
\text { "cinco mil quilogramas"... e coloquem a velocidade do caminhão aí... "cinco } \\
\text { metros por segundo"... beleza? Agora do lado oposto vocês vão desenhar um } \\
\text { carrinho pequeno... de frente para o caminhão... a massa do carro "mil } \\
\text { quilogramas"... coloquem aí a velocidade do carro "vinte e cinco metros por } \\
\text { segundo"... ((professor resolve algumas dúvidas de alguns grupos))... agora a } \\
\text { pergunta... Qual dos carros possui a maior quantidade de movimento antes da } \\
\text { colisão? } \\
\text { A10: Vai bater professor ((sobre o sinal)). } \\
\text { ((Grupo de análise comenta entre si)) A5: Então deixa que bate... a gente fica } \\
\text { um pouco mais depois cara... é legal cara. } \\
\text { A2: Muito legal... essa aula tá show... } \\
\text { A5: Quer estudar ((inaudível)) cara? } \\
\text { A6: É... um mês... } \\
\text { A2: É a primeira vez que eu estudei na vida ((colegas riem)). } \\
\text { P: Óh... Vocês têm um minuto para fazer essa questão ((alguns alunos ficam } \\
\text { surpresos)). } \\
\text { A2: Mas como que faz essa conta? Mas como que faz essa conta A6? O seu } \\
\text { animal era de frente que o carro. } \\
\text { P: AQUI Ó... Antes de vocês fazerem, quem acha que o caminhão tem a maior } \\
\text { quantidade de movimento erga a mão? Ergue a mão aí ((alguns alunos levantam } \\
\text { a mão)). }\end{array}$ \\
\hline
\end{tabular}

Quadro 12: Cena 1.1

Na cena 1, o professor apresenta um problema sobre um carro e um caminhão que se movimentam em linha reta, um de encontro ao outro. Ele deseja saber qual dos dois tem maior quantidade de movimento (na verdade elas são iguais, pois a maior massa do caminhão é compensada pela grande velocidade do carro). $\mathrm{O}$ aluno 2 possui uma dúvida sobre como fazer os cálculos.

Vale ressaltar, que apesar de ser um problema fechado, a discussão sobre como obter os resultados possibilitou uma ampla discussão envolvendo momentos de argumentação, como pode ser observado a seguir. 


\begin{tabular}{|c|c|c|}
\hline $\begin{array}{l}\text { Tempo inicial } \\
\text { e final da cena }\end{array}$ & Transcrição, Descrição das ações e linguagens & Ciclo Argumentativo \\
\hline \multirow[t]{3}{*}{$\begin{array}{l}01: 09: 55- \\
01: 10: 15\end{array}$} & \multirow{3}{*}{$\begin{array}{l}\text { A2 ((falando só para os colegas)): Nós aqui é o carro... nós } \\
\text { é o carro. } \\
\text { A11: Os dois é a mesma. } \\
\text { A9: Os dois é a mesma. } \\
\text { A6 - É A MESMA os dois... porque cinco dividido... vinte } \\
\text { e cinco dividido por cinco é cinco. } \\
\text { P: Vamos lá? Rapidão... } \\
\text { A2: É a mesma. } \\
\text { A6: É o mesmo. } \\
\text { Aluno de outro grupo falando para A6: Quantidade de } \\
\text { movimento depende de massa e de velocidade... um tem } \\
\text { maior massa e o outro tem maior velocidade. }\end{array}$} & $\begin{array}{c}\text { Definição de variáveis } \\
\text { Explicação }\end{array}$ \\
\hline & & Argumentação \\
\hline & & $\begin{array}{c}\text { Previsão } \\
\text { Abdução } \\
\text { Justificativa } \\
\text { Raciocínio lógico } \\
\text { proporcional }\end{array}$ \\
\hline
\end{tabular}

Quadro 13: Cena 1.2

Alguns alunos ("Os dois é a mesma", "É a mesma" e "É o mesmo") preveem que os dois carros possuem a mesma velocidade, por meio da cooperação entre a linguagem escrita (problema escrito no caderno) e a fala. Ocorre assim a definição de variáveis relevantes ao problema (também por estabelecer a relação da massa e da velocidade dos carros com o fenômeno).

O aluno 6 apresenta um conhecimento especializado pela linguagem algébrica,

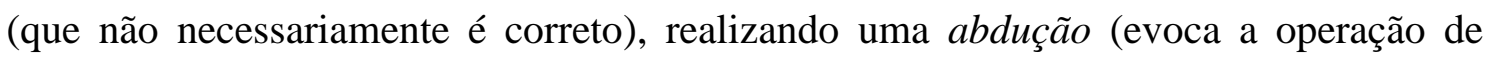
divisão para explicar o fenômeno), porém, a justificativa e, portanto, a explicação são equivocadas apesar de chegar ao resultado correto ("É MESMA os dois... porque 5 dividido... 25 dividido por 5 é 5.). Além disso, ao realizar a operação matemática, ele mistura os dados do caminhão com os do carro.

Enquanto os alunos fazem uma previsão sobre o problema, um aluno de outro grupo explicita seu raciocínio lógico e proporcional ('Quantidade de movimento depende de massa de velocidade... um tem maior massa e o outro tem maior velocidade'), ou seja, o valor é o mesmo, pois há uma compensação entre o excesso de massa de um com a grande velocidade do outro, e apresenta uma justificativa para A6 baseada em proporção, logo a linguagem algébrica especializa os conhecimentos na construção de uma explicação. 


\begin{tabular}{|c|c|c|}
\hline $\begin{array}{l}\text { Tempo inicial e } \\
\text { final da cena }\end{array}$ & Transcrição, Descrição das ações e linguagens & Ciclo Argumentativo \\
\hline \multirow[t]{3}{*}{$\begin{array}{l}01: 10: 15- \\
01: 10: 45\end{array}$} & \multirow{3}{*}{$\begin{array}{l}\text { A1- OH PROFESSOR... Professor é a mesma... } \\
\text { A?: É a mesma professor. } \\
\text { A1: porque um tem a menor massa... mas o outro tem a } \\
\text { maior velocidade ((Professor acena positivamente com a } \\
\text { cabeça)). } \\
\text { A?: É. } \\
\text { A5((Falando para A6)): TÁ... o que tem a menor massa é o } \\
\text { que tem... /// A1: Tem a maior quantidade } \\
\text { A5: ... é o que tem a menor massa... /// A6: Não... o que } \\
\text { tem a maior massa tem a menor velocidade e o que tem } \\
\text { menos massa tem maior velocidade. } \\
\text { A2- Sim... mas tu falou que o que tem menos massa tem } \\
\text { maior velocidade. } \\
\text { A6: Então o que tem menos massa tem a maior velocidade } \\
\text { ((aponta para o caderno)). } \\
\text { A2: E o que tem menor massa tem mais velocidade. } \\
\text { A6: Não... ((alunos dispersam um pouco)). }\end{array}$} & $\begin{array}{c}\text { Definição de variáveis } \\
\text { Explicação }\end{array}$ \\
\hline & & Argumentação \\
\hline & & $\begin{array}{c}\text { Dedução } \\
\text { Justificativa } \\
\text { Raciocínio lógico } \\
\text { proporcional }\end{array}$ \\
\hline
\end{tabular}

Quadro 14: Cena 1.3

Alunos definem as variáveis e sua relação, chegando a uma explicação. As colocações dos alunos 1 e 6 indicam o raciocínio proporcional ('porque um tem a menor massa... mas o outro tem a maior velocidade', 'o que tem a maior massa tem a menor velocidade e o que tem menos massa tem maior velocidade.') na dedução da conclusão, levando a uma justificativa em termos dos conceitos de massa e velocidade, refutando a ideia dos aluno 2 e 5 (“o que tem a menor massa é o que tem...", "mas tu falou que o que tem menos massa tem maior velocidade"), por meio do uso de conhecimentos científicos. A linguagem escrita, a gestual e a visual cooperam na construção desses significados.

É fundamental destacar, que apesar de aparentar compreender o fenômeno, inclusive corrigindo o raciocínio dos seus colegas, o aluno 6 não consegue relacionar a operação matemática usada no cena anterior (divisão) com a explicação apresentada nesse cena.

\begin{tabular}{|l|l|}
\hline $\begin{array}{c}\text { Tempo inicial e } \\
\text { final da cena }\end{array}$ & \multicolumn{1}{c|}{ Transcrição, Descrição das ações e linguagens } \\
\hline 01:10:45 - 01:11:00 & $\begin{array}{l}\text { P((falando para o grupo) }) \text { : Era para calcular... vocês calcularam? } \\
\text { A4: Professor vai bater o sinal... tem que guardar o material ainda. }\end{array}$ \\
& $\begin{array}{l}\text { P: Tem cinco minutos ainda. } \\
\text { A4: Mas eu tenho que guardar o material. }\end{array}$ \\
& $\begin{array}{l}\text { A1: Ir para casa para quê? } \\
\text { A5: Nós também... você não é a única. } \\
\text { A6: É... você não é a única. }\end{array}$ \\
& P: Rápido rápido rápido... é individual. ((professor vai ajudar outros grupos)). \\
\hline
\end{tabular}
Quadro 15: Cena 1.4

Nesta cena, as falas dos alunos 1, 5 e 6 (respectivamente "Ir para casa para quê?", "Nós também... você não é a única..." e "É... você não é a única..."), ao repreenderem a aluna 4 por não querer continuar ("Professor vai bater o sinal... tem que 
guardar o material ainda..." e "Mas eu tenho que guardar o material..."), indicam o envolvimento na atividade e direcionam o foco do grupo para a resolução do problema, ou melhor, este é um momento de 'fazer ciência' no referencial de Jiménez-Aleixandre et. al. (2000).

\begin{tabular}{|l|l|c|}
\hline $\begin{array}{c}\text { Tempo inicial } \\
\text { e final da cena }\end{array}$ & \multicolumn{1}{|c|}{ Transcrição, Descrição das ações e linguagens } & Ciclo Argumentativo \\
\hline $01: 11: 00-$ & A2: O professor a gente está tentando pensar. & \\
$01: 11: 20$ & A1: A gente tem que dividir, né? & Definição de variáveis \\
& A2: Já pensou aí como se faz? ((alunos escrevem no & Explicac̃a \\
& caderno)). & \\
& A1: Dividi né? & \\
& A2: Cinco dividido por... /// A5: Os dois tem mesma... & Argumentação \\
& A6: Cinco. & \\
& A5: Vinte e cinco divido por cinco é cinco. & \\
& A1: Tem que divi/... tem que soma/... tem que fazer a & Abdução \\
& conta... & Dedução \\
& A3: Tem que fazer aquela V1. & Justificativa \\
& A6: Então. & \\
& A3: Então... é aquilo que tem no caderno... pesquisa no & \\
& caderno que você (acha). & \\
\hline
\end{tabular}
Quadro 16: Cena 1.5

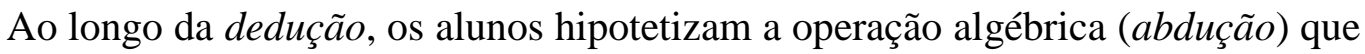
lhes parece representar melhor a conservação, ou seja, a divisão parece adequada para justificar a repartição da quantidade de movimento nos corpos que colidem ("A gente tem que dividir, né?', 'Cinco dividido por...', 'Vinte e cinco divido por cinco é cinco' etc). A linguagem algébrica especializa essa conclusão. Novamente a abdução não é correta, isto é, a regra escolhida não é válida para explicar a situação.

A aluna 3 tenta buscar os conhecimentos anteriores sobre velocidade média ('Tem que fazer aquela V1'), realizando um raciocínio abdutivo, para tentar calcular (dedução) e justificar o porque de tais contas por meio da autoridade científica, porém, sem refletir sobre como esses conhecimentos se relacionam à nova situação. Os colegas do grupo ignoram a sua colocação.

\begin{tabular}{|c|c|c|}
\hline $\begin{array}{l}\text { Tempo inicial } \\
\text { e final da cena }\end{array}$ & Transcrição, Descrição das ações e linguagens & Ciclo Argumentativo \\
\hline \multirow[t]{3}{*}{$\begin{array}{c}01: 11: 20- \\
01: 11: 50\end{array}$} & \multirow{3}{*}{$\begin{array}{l}\text { A2: ((escrevendo e falando)) Vinte e cinco dividido por } \\
\text { cinco... Quanto que é Vinte e cinco dividido por cinco? } \\
((\text { para A1)) /// A4 ((para A5)): E o seu caderno... deixa eu } \\
\text { ver o seu caderno. } \\
\text { A5: Quanto? } \\
\text { A1: Cinco ((alunos anotam no caderno })) \text {. } \\
\text { A5: O que é isso cara? } \\
\text { A2: Cinco... e quanto é cinco mil....... cinco mil é três zero, } \\
\text { certo? ((colegas riem)) } \\
\text { A1 ((em tom de deboche })) \text { : Eu acho que sim. } \\
\text { A5: Você está de brincadeira? } \\
\text { A6: É cinco? ((depois de fazer as contas em seu caderno)). } \\
\text { A2: Vai dar a mesma coisa. }\end{array}$} & Definição de Variáveis \\
\hline & & Argumentação \\
\hline & & Dedução \\
\hline
\end{tabular}

Quadro 17: Cena 1.6 
Alunos definem variáveis no processo de dedução, no qual a linguagem algébrica coopera na construção dos significados.

Aqui verificamos como a abdução incorreta resultou em uma dedução também incorreta (mesmo chegando ao resultado qualitativo correto): “A6: É cinco?”, “A2: Vai dar a mesma coisa".

\begin{tabular}{|c|c|c|}
\hline $\begin{array}{c}\text { Tempo } \\
\text { inicial e final } \\
\text { da cena }\end{array}$ & $\begin{array}{c}\text { Transcrição, Descrição das ações e } \\
\text { linguagens }\end{array}$ & Ciclo Argumentativo \\
\hline \multirow[t]{3}{*}{$\begin{array}{l}01: 11: 50- \\
01: 12: 10\end{array}$} & \multirow{3}{*}{$\begin{array}{l}\text { P: Vamos lá então? } \\
\text { A2: Aí dá cinco... dá a mesma coisa. } \\
\text { P: Qual é a quantidade de movimento maior? } \\
\text { A6: Cinco } \\
\text { Vários alunos: São iguais. } \\
\text { A9: Os dois vão o mesmo número de } \\
\text { movimento ((inaudível)). } \\
\text { A7: A massa de um é maior... mas a } \\
\text { velocidade do outro é maior... }\end{array}$} & Explicação \\
\hline & & Argumentação \\
\hline & & $\begin{array}{c}\text { Dedução } \\
\text { Justificativa } \\
\text { Raciocínio lógico e proporcional }\end{array}$ \\
\hline
\end{tabular}

$$
\text { Quadro 18: Cena } 1.7
$$

Alunos concluem a dedução de que as quantidades de movimento são iguais. A justificativa é dada pelo uso da linguagem algébrica que especializa os significados. Além disso, a aluna 7 expressa o raciocínio proporcional ('A massa de um é maior... mas a velocidade do outro é maior...'), na construção da explicação.

\section{Resumo do episódio 1}

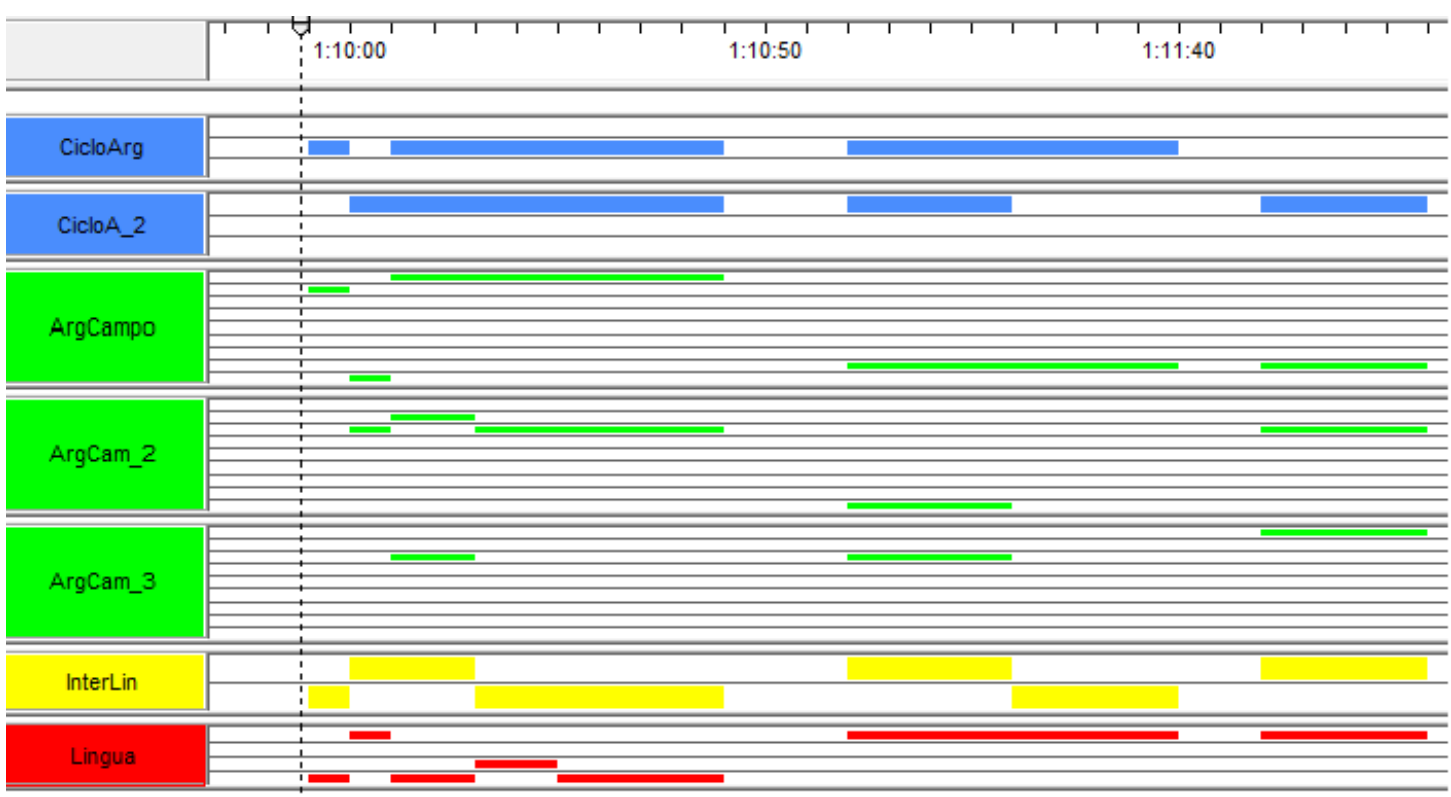

Figura 22: Resumo do episódio 1 
Sobre o ciclo argumentativo, a figura 22 mostra que a definição de variáveis foi essencial para estabelecer a explicação, ao longo do processo argumentativo. Ressaltamos que a etapa de cuidado com os dados foi dada pelo professor ao apresentar o problema fechado.

Ocorreu ainda um movimento intenso das características campo-dependentes da argumentação científica, no qual a linguagem algébrica esteve bastante presente durante o processo dedutivo (o que é esperado par esse tipo de situação - resolução de problemas), trazendo significados novos (especialização), ou seja, a quantidade de movimento é a mesma, e justificando as afirmações.

A abdução realizada também esteve acompanhada da especialização dos significados por meio da linguagem algébrica, mesmo que a regra utilizada para amparar as conclusões tenha sido errada. Nossa hipótese é que o professor passou muito rápido pela equação (vale destacar que ela foi apresentada oralmente, ou melhor, como a atividade foi feita no pátio, o professor não dispunha de outros recursos para introduzir os conceitos e suas representações), deixando um 'abismo' entre a representação algébrica e o fenômeno. Dessa forma, ao resolverem o problema, os alunos apresentam dificuldade de relacionar a equação com a quantidade de movimento do carro e do caminhão, apesar de deixarem claro que a grande massa do caminhão é compensada por sua baixa velocidade, e que a grande velocidade do carro é compensada por sua massa menor, resultando em quantidades de movimento iguais. Lançaremos luz sobre essa questão em episódios posteriores.

Quanto a qualidade argumentativa do episódio observamos que:

- Ao longo das cenas 1.2 e 1.3 , a regra de divisão é usada equivocadamente pelo aluno 6 para justificar a explicação. Um raciocínio proporcional envolvendo os conceitos de massa é corretamente usado por um aluno de outro grupo e pelos alunos 1 e 6 para justificar o resultado, refutando as ideias dos alunos 2 e 5 por meio de conceitos científicos.

- Na cena 1.5, a divisão é usada como justificativa (raciocínio abdutivo) pela aluna 3 , ou seja, ela busca respaldar-se na autoridade do conceito de um conhecimento anterior (velocidade média) sem refletir sobre a sua aplicabilidade na presente situação.

- Durante a cena 1.7, a aluna 7 vale-se de um raciocínio proporcional para justificar o resultado do problema. 
Dessa forma, em relação a forma para coordenar alegações e evidências, os alunos apresentaram justificativas para suas alegações sem precisarem ser desafiados (Sandoval e Milwood, 2007) e apresentam refutações com base nos conceitos em evidência (Sampson e Clark, 2006), o que indica um boa qualidade argumentativa. Porém, a alegação da aluna 3 na cena 1.5, usando do conceito de velocidade média para justificar a conta, é oferecida sem relação com os outros elementos do argumento em desenvolvimento, o que reduz a qualidade argumentativa segundo Sandoval e Milwood (op. cit.).

Quanto aos conteúdos para coordenar alegações e evidências, os conceitos de massa e velocidade, amparados por raciocínios lógicos e proporcionais, foram essenciais para respaldar a conclusão de que as quantidades de movimento são iguais. Por outro lado, houve o uso equivocado da divisão e do conceito de velocidade média para amparar o resultado. Esses fatos indicam uma compreensão conceitual parcial, na qual há uma desconexão entre fenômenos e representação matemática, havendo a necessidade de um trabalho específico na construção dessa relação. Sendo assim, julgamos a qualidade argumentativa desse episódio como mediana.

\section{Episódio 2 - Problemas abertos (atividade 3 da SEI)}

Esse episódio ocorreu no meio da segunda aula dupla da SEI, após a sistematização e formalização do conceito de quantidade de movimento pelo professor, que resolveu um exemplo de problema aberto e, depois, introduziu os problemas abertos da atividade $3^{28}$ da SEI para que os alunos a resolvessem em grupos na sala de aula.

Os alunos do grupo de análise foram nomeados da seguinte forma:

\footnotetext{
28 “1 - Qual a máxima quantidade de movimento que você consegue transferir a uma bola durante um pênalti?"; "2 - Consequentemente, qual é a velocidade adquirida pela bola logo após o chute?"; "3 - Toda quantidade de movimento do pé é transferida à bola? Explique"; "4 - Discuta como a matemática auxilia no entendimento e na resolução das situações descritas nos problemas anteriores”.
} 


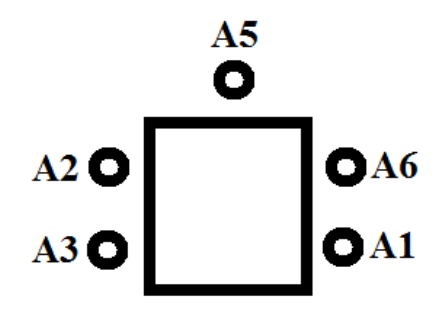

Figura 23: grupo de análise

Apresentamos a seguir a discussão desses estudantes sobre a resolução do primeiro problema aberto ("Qual a máxima quantidade de movimento que você consegue transferir a uma bola durante um pênalti?"). Com o objetivo de não estender demais a análise, começamos a discussão a partir do momento em que inicia a justificação do conhecimento e das estimativas produzidas - no início da discussão os alunos apenas seriam, classificam e organizam as informações. O diálogo completo com as categorias identificadas encontra-se no anexo VI.

\begin{tabular}{|c|c|c|}
\hline $\begin{array}{c}\text { Tempo } \\
\text { inicial e final } \\
\text { da cena } \\
\end{array}$ & Transcrição, Descrição das ações e linguagens & Ciclo Argumentativo \\
\hline \multirow[t]{3}{*}{$\begin{array}{c}00: 39: 00- \\
00: 39: 45\end{array}$} & \multirow{3}{*}{$\begin{array}{l}\text { A2: a bola de futebol de campo é pesadinha. } \\
\text { A5: Ôh como é que vai ficar aí? } \\
\text { A3: Então... que... /// A1: Não... não chega a ter dois quilos. } \\
\text { A6: ÔH você não entende de futebol... você só ajuda a fazer... } \\
\text { você não entende de jogo ((A5 cutuca o braço de A6 e olha } \\
\text { com desaprovação)). } \\
\text { A3: Então vai ((xinga))... beleza... não vou falar mais nada.... } \\
\text { façam sozinhos aí. } \\
\text { A5 ((para A6)): não faz essas coisas velho. } \\
\text { A6: Eu não óh... } \\
\text { A2: Deve ter um quilo eu acho. } \\
\text { A1: Um quilo... (nem) ((acena negativamente com a cabeça)). } \\
\text { A5: Não... a massa...a massa... o 'MV' Aluno } 6 . . . \text { é só tu olhar } \\
\text { no quadro... massa vezes a velocidade... né? E vai ser/ e o Q é } \\
\text { a quanti/? ... tá... qual vai ser a massa? } \\
\text { A5: Pô... Assim não dá... vou falar para o professor que eu não } \\
\text { quero mais fazer isso... } \\
\text { A2: Eu também não quero... O professor fica filmando a } \\
\text { gente. }\end{array}$} & $\begin{array}{l}\text { Cuidado com os dados } \\
\text { Definição das } \\
\text { variáveis relevantes ao } \\
\text { problema }\end{array}$ \\
\hline & & Argumentação \\
\hline & & $\begin{array}{c}\text { Seriação } \\
\text { Classificação e } \\
\text { organização dos dados } \\
\text { Justificativa }\end{array}$ \\
\hline
\end{tabular}
Quadro 19: Cena 2.1

O aluno 2 tenta justificar a sua estimativa pelo uso da noção empírica de peso ("a bola de futebol de campo é pesadinha"), no processo de cuidado com os dados e definição de variáveis. Nota-se que há uma confusão sobre os valores estimados, pois o primeiro problema aberto proposto refere-se à máxima quantidade de movimento que o jogador pode transferir à bola durante o pênalti. Por outro lado, os estudantes estimam valores para a bola. Por meio das filmagens, não é possível perceber se eles consideram que a quantidade de movimento é totalmente transferida do pé para a bola e, portanto, se eles estão calculando a quantidade de movimento da bola para inferir que foi essa a 
quantidade de movimento máxima que foi transferida pelo pé/jogador. A julgar pela dificuldade apresentada pelo grupo para modelizar matematicamente o problema (como pode ser observado a seguir), descartamos essa possibilidade.

O aluno 6 não deixa a aluna 3 concluir sua ideia ("ÔH você não entende de futebol... você só ajuda a fazer... você não entende de jogo"), caçoando da mesma muito provavelmente por ela ser mulher; o aluno 1 também não concorda com a massa de dois quilogramas, mas não apresenta uma justificativa, isso tudo indica uma baixa qualidade argumentativa. Sendo assim, a aluna 3 diz magoada que não vai mais participar, mas os colegas não dão muita atenção apesar do aluno 5 repudiar a ação do aluno 6 ("não faz essas coisas velho").

O aluno 5 chama a atenção do colega que dispersou e traz foco para a discussão, ajudando a seriar, classificar e organizar as informações relevantes para a resolução do problema ("Não... a massa...a massa... o 'MV' Aluno 6... é só tu olhar no quadro... massa vezes a velocidade... né? E vai ser/ e o Q é a quanti/? ... tá... qual vai ser a massa?”). Isso mantém o foco no cuidado com os dados e na definição das variáveis relevantes ao problema. A linguagem matemática coopera na construção dos significados.

Os estudantes parecem incomodados com a presença da câmera ("Eu também não quero... O professor fica filmando a gente"), mas logo se esquecem da mesma, tal como pode ser observado no diálogo adiante, no qual a argumentação flui naturalmente. 


\begin{tabular}{|c|c|c|}
\hline $\begin{array}{l}\text { Tempo inicial } \\
\text { e final da cena }\end{array}$ & Transcrição, Descrição das ações e linguagens & Ciclo Argumentativo \\
\hline \multirow[t]{3}{*}{$\begin{array}{c}00: 39: 45- \\
00: 40: 30\end{array}$} & \multirow{3}{*}{$\begin{array}{l}\text { A5: Qual vai ser a massa? } \\
\text { A2: Um quilo. } \\
\text { A1: Quantos quilos? Quantos quilos? } \\
\text { A6: Não... não... a bola não tem um quilo... tem dois. } \\
\text { A5: Ah tá ((desdenhando)). } \\
\text { A2: Eu falei dois... eles falaram que era impossível. } \\
\text { A6: Não... tem mais. } \\
\text { A5: Não... não... a bola não tem dois quilos ((balança a } \\
\text { cabeça negativamente)). } \\
\text { A1: Não chega a ter dois quilos. } \\
\text { A5: Não. } \\
\text { A3 ((para A1)): Não tem... a gente fez um trabalho... não } \\
\text { tem dois quilos ((inaudível)). /// A2: Tem... a de futebol de } \\
\text { campo tem. } \\
\text { A6: A de dois quilos tem dois quilos ((se referindo à bola de } \\
\text { campo)). } \\
\text { A5: Ela é levinha para caramba. } \\
\text { A6: A de campo tem dois quilos sossegada. } \\
\text { A2: Vai... joga dois quilos aí. } \\
\text { A5: Dois quilos tem a de quadra... dois quilo tem... a bola de } \\
\text { quadra é mais pesada e tem dois quilos. } \\
\text { A2: Cala a boca a bola é mais pesada ((de campo)). } \\
\text { A6: A de quadra é mais pesada do que a de campo. } \\
\text { A5: Dois quilos tem a bola de quadra. /// A3 ((falando para } \\
\text { A1 e rindo)): É de cimento. } \\
\text { A6: Não a de campo tem dois quilos... pode colocar ali. /// } \\
\text { A1: Há? /// A3: É de cimento. } \\
\text { A5: Vamos colocar um quilo e meio então. } \\
\text { A6: Não dois quilos. } \\
\text { A5: UM QUILO E MEIO. }\end{array}$} & $\begin{array}{l}\text { Cuidado com os dados } \\
\text { Definição das } \\
\text { variáveis relevantes ao } \\
\text { problema }\end{array}$ \\
\hline & & Argumentação \\
\hline & & $\begin{array}{c}\text { Seriação } \\
\text { Classificação e } \\
\text { organização dos dados } \\
\text { Justificativa }\end{array}$ \\
\hline
\end{tabular}

Quadro 20: Cena 2.2

O grupo faz estimativas sobre a massa da bola procurando justificar os diferentes pontos de vista apesar de haver algumas discordâncias (tal como a do aluno 2: “Cala a boca a bola é mais pesada ((de campo))"), possibilitando a seriação, classificação e organização dos dados sobre o problema: a justificativa da aluna 3 se baseia em seus conhecimentos prévios ("Não tem... a gente fez um trabalho... não tem dois quilos"); o aluno 5 tenta refutar a estimativa dos alunos 2 e 6 (dois quilogramas para a bola de campo) com base no conceito intuitivo de peso ("Ela é levinha para caramba") e, depois, por meio do tipo de bola ("Dois quilos tem a de quadra... dois quilo tem... a bola de quadra é mais pesada e tem dois quilos”); o aluno 6 concorda com a justificativa do tipo de bola, mas discorda sobre o valor da massa ("A de quadra é mais pesada do que a de campo"; "Não a de campo tem dois quilos... pode colocar ali").

A aluna 3 mostra acompanhar a discussão quando se dirige ao aluno 1 (“... é de cimento..."), ao mesmo tempo ela refuta as estimativas dos colegas devido ao conhecimento sistematizado que ela possui em virtude da pesquisa que a mesma relatou. Ela ainda usa a analogia do cimento para enfatizar que valor para a massa é excessiva (o 
que mostra a boa qualidade de sua argumentação, já que ela justifica sua posição usando uma analogia). Seus colegas não lhe dão atenção, provavelmente por ela ser mulher, sendo assim, ao longo dessa etapa do processo de cuidado com os dados e definição dos valores das variáveis, a argumentação tem uma qualidade relativa, visto que ao mesmo tempo em que os estudantes respaldam-se em analogias, conhecimentos empíricos $e$ sistematizados para produzir suas justificações, eles ignoram a contribuição importante da colega provavelmente por causa do seu sexo (isso fica evidente na cena anterior). A linguagem matemática coopera na construção dos significados ao longo das argumentações apresentadas.

\begin{tabular}{|c|c|c|}
\hline $\begin{array}{l}\text { Tempo inicial } \\
\text { e final da cena }\end{array}$ & Transcrição, Descrição das ações e linguagens & Ciclo Argumentativo \\
\hline \multirow[t]{3}{*}{$\begin{array}{l}00: 40: 30 \\
00: 41: 30\end{array}$} & \multirow{3}{*}{$\begin{array}{l}\text { A6: EI o professor falou que tem que ser redondo... para ser } \\
\text { mais fácil de... /// A5: Então faz cinco ((ri de A6)). } \\
\text { A6: Cala a boca... eu vou colocar dois quilos... porque tem } \\
\text { que fazer do seu jeito. } \\
\text { A2: Faz dois cara. } \\
\text { A5: Tá bom... tá... a dois... ele vai ficar o que aí. } \\
\text { A1: Bora fazer uma peca de cimento aí. } \\
\text { A2: Oitenta por hora... a velocidade normalmente é. } \\
\text { A6: NÃO:: cara } \\
\text { A5: A velocidade no chute... não/a bola. } \\
\text { A6: A do chute? /// A5: Nós temos que descobrir:..: } \\
\text { A6: Não... nós temos que hipotetizar. } \\
\text { A5: Daí nós temos que ter dois números... daí depois vai ter } \\
\text { que mudar ali ((aponta para lousa))... para estar div/tá } \\
\text { multiplicando passa div/vai trocar o Q. } \\
\text { A6: Tá. } \\
\text { A5: Ah aquela ali não faz nada... não ajuda nada ((sobre a } \\
\text { aluna 3)). } \\
\text { A3: Eu fui falar e esse aqui ficou enchendo o saco... então eu } \\
\text { não vou falar ((xingamento))... /// A5: Você não pode levar } \\
\text { esse cara a sério o que o aluno } 6 \text { fala. } \\
\text { A1: Quer uma dica? Ignora. } \\
\text { A5: Como é que uma namorada vai ignorar o seu namorado } \\
\text { ((brincando)). } \\
\text { A1 ((falando para A3)): É... esquece... esquece. } \\
\text { A5: Vai vamos fazer ((inaudível)). } \\
\text { A3: Para de falar ((inaudível)) que está filmando. }\end{array}$} & $\begin{array}{l}\text { Cuidado com os dados } \\
\text { Definição das } \\
\text { variáveis relevantes ao } \\
\text { problema }\end{array}$ \\
\hline & & Argumentação \\
\hline & & $\begin{array}{c}\text { Seriação } \\
\text { Classificação e } \\
\text { organização dos dados } \\
\text { Justificativa } \\
\text { Dedução }\end{array}$ \\
\hline
\end{tabular}
Quadro 21: Cena 2.3

Nesta cena, os estudantes continuam a seriar, classificar e organizar os dados, dentro das etapas de cuidado com os dados e definição das variáveis relevantes ao problema do ciclo argumentativo. $\mathrm{O}$ aluno 5 caçoa do aluno $6 \mathrm{em}$ vez de justificar sua posição ("Então faz cinco") e a justificativa do aluno 6 baseia-se na autoridade do professor (“... tem que ser redondo...") e dele mesmo ("porque tem que fazer do seu jeito"). O aluno 1 sugere a peca ou bola de cimento, apropriando-se da ideia da aluna 3 apresentada na cena anterior, como justificativa para mostrar que a estimativa da massa da bola está muito alta, mas os colegas o ignoram e começam a estimar a velocidade. $\mathrm{O}$ 
aluno 2 aceita o valor de massa por comodidade ("Faz dois cara”), algo que ele já vinha fazendo na cena anterior ("Vai... joga dois quilos aí".). Essas ações limitam a qualidade do processo argumentativo e indicam que a ação desse estudante é para resolver o problema de forma 'burocrática', ou seja, como parte da rotina escolar para atender a demanda do professor, igual ao 'fazer escola' apontado por Jiménez-Aleixandre et. al. (2000). Em contrapartida, nas cenas a seguir ele volta a participar ativamente do processo, buscando justificar suas estimativas (talvez pela natureza contextualizada do problema que demanda conhecimentos sobre um tema de interesse dos participantes).

A linguagem matemática na lousa ajuda o aluno 5 a justificar de forma cooperativa o que tem que ser feito para deduzir o resultado do problema ("Daí nós temos que ter dois números... daí depois vai ter que mudar ali ((aponta para lousa))... para estar div/tá multiplicando passa div/vai trocar o Q"), ou seja, justifica-se através do apelo a um exemplo (que é destacado cooperativamente pelo gesto deste aluno) - o que dá força ao argumento. $\mathrm{O}$ aluno 6 parece concordar com a visão desse aluno ("Tá").

A aluna 3 recusa-se a participar, mesmo quando o aluno 5 solicita, pois ela ficou ressentida por seus colegas não considerarem suas ideias na cena 2.1.

\begin{tabular}{|c|c|c|}
\hline $\begin{array}{l}\text { Tempo inicial } \\
\text { e final da cena }\end{array}$ & Transcrição, Descrição das ações e linguagens & Ciclo Argumentativo \\
\hline \multirow[t]{3}{*}{$\begin{array}{c}00: 41: 30 \text { - } \\
00: 42: 30\end{array}$} & \multirow{3}{*}{$\begin{array}{l}\text { P ((falando para toda a sala)): PESSOAL SUGESTÃO... } \\
\text { primeira questão é isso aqui ((aponta esquema }{ }^{29} \text { no quadro } \\
\text { no qual há o choque de dois objetos))... não é nada diferente } \\
\text { disso aqui... a única coisa que você vai ter que:: hipotetizar é } \\
\text { o valor de:: massa da bola e velocidade da bola. } \\
\text { A5: Ah então... o 'A' vai ser a perna do carinha... que está } \\
\text { parado... } \\
\text { A2: A bo/o 'A' está parado. /// A5: a não o 'B' está parado. } \\
\text { A2: O B é a bola. /// A5: O B é a bola... certão. } \\
\text { A2: E o 'A' é a perna. } \\
\text { A5: Aí só vai inverter o:.... qual que está em movimento? O } \\
\text { B né? } \\
\text { A2: Não cara é o A. /// A1: O A. } \\
\text { A5: Então o A vai ser a perna/que eu falei. } \\
\text { A2: Tu falou que a::: per/a:: bola /// A5: A PERNA. } \\
\text { A6: Tu falou a bola a bola. } \\
\text { A1: Tu falou que a bola ia ser o movimento. } \\
\text { A5: Sim ela ia se movimentar... } \\
\text { A2: Não.. } \\
\text { A5: Ia... ia. } \\
\text { A2: Não. Estou com vontade de comer ((inaudível)). } \\
\text { A1: TÁ... esquece } \\
\text { A2: Sem zueira... deu uma vontade agora... estou quebrado. }\end{array}$} & $\begin{array}{c}\text { Cuidado com os dados } \\
\text { Definição das } \\
\text { variáveis relevantes ao } \\
\text { problema } \\
\end{array}$ \\
\hline & & Argumentação \\
\hline & & $\begin{array}{c}\text { Seriação } \\
\text { Classificação e } \\
\text { organização dos dados }\end{array}$ \\
\hline
\end{tabular}

Quadro 22: Cena 2.4

\footnotetext{
${ }^{29}$ No exemplo no quadro, uma bola choca-se com outra e são sugeridas e calculadas três opções de conservação: 1- toda a quantidade de movimento da primeira bola é transferida para a segunda; 2 e 3 - a quantidade de movimento da primeira e transferida parcialmente para a segunda.
} 
Em decorrência da intervenção do professor ("não é nada diferente disso aqui... a única coisa que você vai ter que:: hipotetizar é o valor de:: massa da bola e velocidade da bola"), o grupo compara o desenho na lousa (que mostra o choque entre dois objetos) com o problema em processo de resolução, classificando e organizando as informações, modelizando a situação de forma a possibilitar o desenvolvimento da dedução (que se inicia na cena 2.6), no processo de cuidado com os dados e definição de variáveis. A linguagem visual e a matemática cooperam nesse processo.

Entretanto, não é possível observar se esses estudantes fazem essa modelização consciente nesse momento. Conforme veremos na cena 6.7, eles apenas compreendem que modelizar é copiar do exemplo, isto é, eles não fazem uma transferência crítica entre o conhecimento novo e o exemplo.

\begin{tabular}{|c|c|c|}
\hline $\begin{array}{c}\text { Tempo } \\
\text { inicial e final } \\
\text { da cena }\end{array}$ & Transcrição, Descrição das ações e linguagens & Ciclo Argumentativo \\
\hline \multirow[t]{3}{*}{$\begin{array}{l}00: 42: 30 \text { - } \\
00: 43: 20\end{array}$} & \multirow{3}{*}{$\begin{array}{l}\text { A5: Tá... éh.:. e tá... E que velocidade que a perna vai ir? Já } \\
\text { descobriram já? } \\
\text { A2: Oitenta. } \\
\text { A6: Sessenta sessenta. } \\
\text { A2: Pra mim é chute... cara. } \\
\text { A5: TÁ... mas quanto colocar? Colocar quanto então? } \\
\text { A6: Sessenta. } \\
\text { A1: Oitenta. } \\
\text { A2: Oh sessenta meu irmão de dez ((anos)). /// A1: Oitenta. } \\
\text { A5: Éh:: tá oitenta oitenta. } \\
\text { A6: Tá tu acha que tu vai pegar oitenta quilômetros por hora? } \\
\text { A5: Claro que pega aluno } 6 . . . \text { não parece porque a distância é } \\
\text { curta... mas da um ((chute)) com força/pega aquele/aquelas } \\
\text { bagaça e coloca na tua perna pra ver... a velocidade do chute... } \\
\text { dá para fazer/ dá para fazer. /// A2: Eu acho que chega... até } \\
\text { oitenta. } \\
\text { A5: Claro que chega a oitenta. } \\
\text { A2: Eu acho que chega. } \\
\text { A5: Se a bola chega a oitenta por hora... a velocidade... do } \\
\text { chute na hora de chutar tem que ser pelo menos a:.... pelo } \\
\text { menos não... tem que ser mais da metade do do... da } \\
\text { velocidade da bola... oitenta dá. } \\
\text { A6: Então vai... } \\
\text { A5: O cara chuta... o cara chutou a bola de um quilo a oitenta } \\
\text { por hora. } \\
\text { A6: De dois quilos. } \\
\text { A5: Dois quilos é... certo. } \\
\text { A2: A oitenta por hora. }\end{array}$} & $\begin{array}{l}\text { Cuidado com os dados } \\
\text { Definição das } \\
\text { variáveis relevantes ao } \\
\text { problema }\end{array}$ \\
\hline & & Argumentação \\
\hline & & $\begin{array}{c}\text { Seriação } \\
\text { Classificação e } \\
\text { organização dos dados } \\
\text { Justificativa } \\
\text { Previsão } \\
\text { Raciocínio Lógico e } \\
\text { Proporcional }\end{array}$ \\
\hline
\end{tabular}

Quadro 23: Cena 2.5

Nessa cena, ainda no processo de cuidado com os dados e de definição das variáveis relevantes ao problema, no qual há a classificação e organização dos dados, os alunos procuram estimar e justificar os valores para velocidade da bola. $\mathrm{O}$ aluno 2 procura refutar o valor de $60 \mathrm{~km} / \mathrm{h}$ apelando implicitamente para a força que seu irmão 
mais novo é capaz de imprimir à bola (“Oh sessenta meu irmão de dez”). O aluno 6 duvida do valor da velocidade ("Tá tu acha que tu vai pegar oitenta quilômetros por hora?") e o aluno 5 justifica pela distância ser curta e usa a autoridade de um medidor para apoiar sua afirmação (“não parece porque a distância é curta... mas da um ((chute)) com força/pega aquele/aquelas bagaça e coloca na tua perna pra ver... a velocidade do chute... dá para fazer/ dá para fazer").

Em seguida o aluno 5 prevê que a velocidade do pé tem que ser pelo menos mais da metade da velocidade da bola ("Se a bola chega a oitenta por hora... a velocidade... do chute na hora de chutar tem que ser pelo menos a::... pelo menos não... tem que ser mais da metade do do... da velocidade da bola... oitenta dá"). Isso expressa também um raciocínio lógico e proporcional, ou seja, esse estudante provavelmente tem a noção de conservação internalizada, logo, é possível que ele perceba intuitivamente que o fato de a perna ter massa muito maior que a bola, implica em uma grande transferência de quantidade de movimento para a bola, resultando na velocidade estimada/prevista aproximadamente duas vezes maior que a da perna.

\begin{tabular}{|c|l|c|}
\hline $\begin{array}{c}\text { Tempo inicial } \\
\text { e final da cena }\end{array}$ & \multicolumn{1}{|c|}{ Transcrição, Descrição das ações e linguagens } & Ciclo Argumentativo \\
\hline & A6: Tá agora divide por... & $\begin{array}{c}\text { Definição das } \\
\text { variáveis relevantes ao } \\
\text { problema }\end{array}$ \\
& A5: Quarenta. & \\
& A6: Quarenta. & A2: Tá e (o que que é quarenta)? \\
\cline { 2 - 3 } $00: 43: 20-$ & A6: AH::: ai vai dar um mesmo bagulho louco... se nós fizer & Argumentação \\
$00: 43: 40$ & vai dar o mesmo troço lá óh ((aponta para a lousa)). & \\
& A5: A resposta é vinte e cinco professor ((alunos em tom de \\
& brincadeira consideram os cálculos que estão na lousa, da & \\
& forma como estão, no problema que estão resolvendo)). & Classificação e \\
& A2: Já está tudo feito. & organização dos dados \\
& A1: Vinte e cinco? & Abdução \\
& A6: O professor. & Dedução \\
& A5: Olha lá... o resultado é vinte e cinco... olha lá. & \\
& A1: Não era quarenta? &
\end{tabular}
Quadro 24: Cena 2.6

Os alunos classificam e organizam os dados, enquanto definem as variáveis relevantes ao problema, quando dividem $80 \mathrm{~km} / \mathrm{h}$ por $2 \mathrm{~kg}$, deduzindo o resultado 40 $\mathrm{km} / \mathrm{h}$ para a velocidade. É interessante notar que a regra 'divisão' continua ser usada como no episódio 1 para realizar os cálculos (abdução). A linguagem matemática e a escrita especializam os significados deduzidos (o valor da quantidade de movimento máxima que pode ser transferida à bola).

É perceptível o erro ao modelizar o problema e o valor equivocado alcançado, os estudantes não fazem a uma 'ponte' entre a noção de conservação construída (conforme evidências do episódio anterior) e as representações matemáticas. Eles buscam 
relacionar a sua dedução ao modelo em destaque na lousa no lugar de interpretar fisicamente a situação ("A6: AH::: ai vai dar um mesmo bagulho louco... se nós fizer vai dar o mesmo troço lá óh ((aponta para a lousa))"; “A2: Já está tudo feito”).

\begin{tabular}{|c|c|c|}
\hline $\begin{array}{c}\text { Tempo } \\
\text { inicial e final } \\
\text { da cena }\end{array}$ & Transcrição, Descrição das ações e linguagens & Ciclo Argumentativo \\
\hline \multirow[t]{3}{*}{$\begin{array}{c}00: 43: 40- \\
00: 44: 30\end{array}$} & \multirow{3}{*}{$\begin{array}{l}\text { A6: ÔH PROFESSOR. } \\
\text { P: Oi. } \\
\text { A6: Óh... suponhamos que a bola tem } 2 \text { quilos e a pressão do } \\
\text { chute vai dar } 80 \text { quilômetros por hora... daí divide o } \\
\text { ((inaudível)) vezes... daí divide e dá } 40 . \\
\text { P: Primeiro... a velocidade tem que ser em metros por } \\
\text { segundo. } \\
\text { A5: AH.: é oitenta metros por segundo. /// P: É oitenta metros } \\
\text { por segundo. } \\
\text { A6: É oitenta metros por segundo. } \\
\text { P: Bicho... /// A5: Tá... é muito. } \\
\text { P: A oitenta quilômetros por hora. } \\
\text { A6: Eu falei para vocês ((inaudível, pois A5 e A6 falam algo } \\
\text { ao mesmo tempo)). } \\
\text { A5: Eu acho que a velocidade do chute ((inaudível)). } \\
\text { P: Eu acho... eu acho que como vocês estão hipotetizando... } \\
\text { aqui não é interessante agora... trabalhar com valores reais... é } \\
\text { interessante vocês trabalharem com valores que sejam fáceis } \\
\text { de usar... massa da bola... um quilo. } \\
\text { A5: AÍ... VIU? /// P: Velocidade da perna... metros por } \\
\text { segundo. } \\
\text { A5: DOIS QUILOS... eu estava falando até agora. ((A5 ficou } \\
\text { bravo com a estimativa errônea do colega, pois a sua foi mais } \\
\text { realista)). } \\
\text { A6: Mas uma bola tem } 2 \mathrm{~kg} . . . \text { né? } \\
\text { P: Não... uma bola tem } 500 \text { gramas... uma bola de futebol... } \\
\text { A6: De campo? }\end{array}$} & $\begin{array}{l}\text { Cuidado com os dados } \\
\text { Definição das } \\
\text { variáveis relevantes ao } \\
\text { problema }\end{array}$ \\
\hline & & Argumentação \\
\hline & & $\begin{array}{c}\text { Seriação } \\
\text { Classificação e } \\
\text { organização dos dados } \\
\text { Abdução } \\
\text { Dedução }\end{array}$ \\
\hline
\end{tabular}

Quadro 25: Cena 2.7

O aluno 6, além de utilizar o conceito de pressão no lugar de força, usa a operação de divisão como hipótese para deduzir o resultado (abdução), mesmo tendo o modelo de resolução na lousa ('Óh... suponhamos que a bola tem 2 quilos e a pressão do chute vai dar 80 quilômetros por hora... daí divide o ((inaudível)) vezes... daí divide e dá 40').

Os alunos seriam, classificam e organizam as informações a partir do diálogo com o professor, que chama atenção para as unidades usadas ('Primeiro... a velocidade tem que ser em metros por segundo', 'Velocidade da perna... metros por segundo'), para os valores ("Bicho"; "massa da bola... um quilo"; "Não... uma bola tem 500 gramas... uma bola de futebol...") e para o uso de valores que facilitem os cálculos ("aqui não é interessante agora... trabalhar com valores reais... é interessante vocês trabalharem com valores que sejam fáceis de usar...”). 
Assim, o docente faz os alunos realizarem estimativas mais reais, porém, não há justificação dos valores de velocidade escolhidos, dessa forma, na cena a seguir ele estimula os estudantes a justificarem o valor de massa escolhido.

\begin{tabular}{|c|c|c|}
\hline $\begin{array}{l}\text { Tempo inicial e } \\
\text { final da cena }\end{array}$ & Transcrição, Descrição das ações e linguagens & Ciclo Argumentativo \\
\hline \multirow[t]{3}{*}{$00: 44: 30-00: 45: 20$} & \multirow[b]{3}{*}{$\begin{array}{l}\text { ((risos)) } \\
\text { P: Um quilo cara... um quilo de feijão... chuta um quilo } \\
\text { de feijão aí para tu ver. /// A5: Aí óh::. eu não falei... eu } \\
\text { estava mais certo do que vocês... eu falei um quilo. } \\
\text { ((Professor vai ajudar outros grupos)). } \\
\text { A3: Eu falei...né? } \\
\text { A1: É aluno 6. } \\
\text { A3: Eu falei e ele ficou dizendo que eu não entendia de } \\
\text { futebol. } \\
\text { A2: AH... eu quero voltar para a primeira série... ((risos)) } \\
\text { A3: Eu falei e ele falou eu não entendia de futebol. } \\
\text { A5: Eu falei... cara.... ele estava falando um quilo. } \\
\text { A1: Não dá cara. } \\
\text { A5: Mas "não... não... é muito leve" ((imitando e } \\
\text { caçoando A6)). } \\
\text { A2: Cara... mas parece ser mais pesada. } \\
\text { A6: Parece. } \\
\text { A3: Dois quilos ((desdenhando do colega)). } \\
\text { A5: Um quilo tem a de quadra então... a de quadra deve } \\
\text { ter um quilo então. Mas a hipotes/ ((para e fica } \\
\text { pensativo, o aluno } 6 \text { começa a apagar e os demais o } \\
\text { observam e depois começam a escrever. O aluno } 5 \\
\text { começa a escrever e falar)). } \\
\text { A5: Tá... meio quilo... não... é 500g. /// A6: Acabou tua } \\
\text { borracha. } \\
\text { A2: Quanto ele falou por hora? } \\
\text { A5: Empresta um lapisinho... um lápis? } \\
\text { A2: Um metro por segundo? } \\
\text { A1: É metros por segundo. } \\
\text { A5: É metros por segundo. }\end{array}$} & $\begin{array}{c}\text { Definição das } \\
\text { variáveis relevantes ao } \\
\text { problema }\end{array}$ \\
\hline & & Argumentação \\
\hline & & $\begin{array}{c}\text { Seriação } \\
\text { Classificação e } \\
\text { organização dos dados } \\
\text { Justificativa }\end{array}$ \\
\hline
\end{tabular}

Quadro 26: Cena 2.8

A justificativa dada pelo professor apela para uma noção intuitiva da massa, apelando para um conhecimento empírico, como forma de estimular os alunos a refletirem sobre o valor escolhido ('Um quilo cara... um quilo de feijão... chuta um quilo de feijão aí para tu ver.'). Isso faz com que os estudantes seriem, classifiquem e organizem as informações, definindo as variáveis relevantes no ciclo argumentativo.

Dessa forma, apesar das brincadeiras (“A5: Mas "não... não... é muito leve" ((imitando e caçoando A6))."; “A3: Dois quilos ((desdenhando do colega))"), os alunos retomam as suas estimativas abandonadas, tal como a da aluna 3 ("Eu falei e ele falou eu não entendia de futebol'), além de reverem as suas justificativas (“A5: Eu falei... cara.... ele estava falando um quilo"). A linguagem matemática coopera na construção dos significados. 


\begin{tabular}{|c|c|c|}
\hline $\begin{array}{l}\text { Tempo inicial } \\
\text { e final da cena }\end{array}$ & Transcrição, Descrição das ações e linguagens & Ciclo Argumentativo \\
\hline \multirow[t]{3}{*}{$\begin{array}{c}00: 45: 20- \\
00: 45: 45\end{array}$} & \multirow{3}{*}{$\begin{array}{l}\text { A6: Quinhentas gramas uma bola? } \\
\text { A5: Quantos metros por segundo? } \\
\text { A2: Foi o que ele ((professor)) falou. } \\
\text { A1: Oitenta metros por segundo é:: } \\
\text { A5: Digamos que ele vá chutar de fora da grande área. } \\
\text { A1: Não o caso é um pênalti então. } \\
\text { A2: É um pênalti seu. } \\
\text { A5: Vai ser trinta metros por segundo. } \\
\text { A6: Trinta metros por segundo ((inaudível - coloca a mão na } \\
\text { boca)). } \\
\text { A5: Trinta por segundo. /// A2: Então faz aí. } \\
\text { A1: Não... não vai ser tudo isso. } \\
\text { A5: É quinze metros lá do pênalti né? ... MAS É HIPÓTESE } \\
\text { cara... não é para fazer o real... É hipótese. } \\
\text { A6: Então pode ser dez... dez metros por segundo. } \\
\text { A5: Não trint/vinte metros. I// A1: Então vamos botar } \\
\text { que/bota cem metros por segundo que tá valendo. } \\
\text { A2: Mas tem que ter quarenta... divide pela } \\
\text { metade((inaudível)). } \\
\text { A1: Então vai... vinte metros/vinte metros por segundo. } \\
\text { A2: Daí vai dividir e vai dar quarenta? } \\
\text { A1: Conseguiu? Conseguiu? ((para A5)). } \\
\text { A3: Vai dar quatro ((inaudível)). }\end{array}$} & $\begin{array}{l}\text { Cuidado com os dados } \\
\text { Definição das } \\
\text { variáveis relevantes ao } \\
\text { problema }\end{array}$ \\
\hline & & Argumentação \\
\hline & & $\begin{array}{c}\text { Seriação } \\
\text { Classificação e } \\
\text { organização dos dados } \\
\text { Hipótese } \\
\text { Justificativa } \\
\text { Abdução } \\
\text { Dedução }\end{array}$ \\
\hline
\end{tabular}
Quadro 27: Cena 2.9

Os estudantes continuam a seriar, classificar e organizar as informações com base na situação proposta, mas agora refletindo sobre o valor da velocidade da bola (“A5: Digamos que ele vá chutar de fora da grande área"; "A1: Não o caso é um pênalti então"; “A2: É um pênalti seu...”). Aqui novamente há a falta de compreensão sobre o que está sendo modelizado, ou seja, a primeira questão aberta refere-se ao jogador e não a bola.

No diálogo com o aluno 5, o aluno 1 justifica o valor de velocidade estimado como sendo muito alto ('A1: Oitenta metros por segundo é:::' e ‘A1: Não o caso é um pênalti então') e refutando a hipótese do colega ('A5: Digamos que ele vá chutar de fora da grande área'). A garantia dada está implícita, ou melhor, o aluno 1 mostra em decorrência da pequena distância entre a marca do pênalti e o gol a velocidade não pode ser $80 \mathrm{~m} / \mathrm{s}$, caso contrário, não seria possível ver a bola cruzar essa distância com essa velocidade.

O grupo ainda acha que os $30 \mathrm{~m} / \mathrm{s}$ sugeridos pelo aluno 5 é muito alto, levando esse aluno a sugerir $15 \mathrm{~m} / \mathrm{s}$. Esse estudante não tem um entendimento do que é uma estimativa, que deve ser próxima do real, e do que é uma hipótese, o que o leva a fazer uma justificativa errônea não acatada pelo grupo ('É quinze metros lá do pênalti né? ... MAS É HIPÓTESE cara... não é para fazer o real... É hipótese.'). A1 justifica/refuta por 
absurdo que a estimativa desse colega está errada ("Então vamos botar que/bota cem metros por segundo que tá valendo").

A seguir, a partir da fala do aluno 2, que retoma o raciocínio abdutivo, ("Mas tem que ter quarenta... divide pela metade((inaudível))"), o grupo continua a dedução, que continua por mais alguns minutos até o aluno 5 ouvir a intervenção do professor em outro grupo.

\begin{tabular}{|c|c|c|}
\hline $\begin{array}{l}\text { Tempo inicial } \\
\text { e final da cena }\end{array}$ & Transcrição, Descrição das ações e linguagens & Ciclo Argumentativo \\
\hline \multirow[t]{3}{*}{$\begin{array}{c}00: 50: 45- \\
00: 51: 30\end{array}$} & \multirow{3}{*}{$\begin{array}{l}\text { A5 ((ao ouvir o professor conversando com outro grupo)): } \\
\text { Ah:: vai ser... nós fizemos vinte coisa... né? Ela vai passar... } \\
\text { digamos que vai passar... quinze metros por segundo... e no } \\
\text { pé dele vai ficar cinco metros por segundo... entendeu? Vai } \\
\text { dividir o que o professor falou... PROFESSOR... } \\
\text { A6: ÔH PROFESSOR... dá uma mão aqui para nós? } \\
\text { A5: Como o professor falou ali... digamos... a gente tá } \\
\text { supondo que é vinte metros por segundo... daí ele passou e } \\
\text { ficou um pouco de movimento na perna... deixamos cinco } \\
\text { metros por segundo... daí passou quinze metr/ para a bola. } \\
\text { P: Não... tu passou quantidade de movimento... não } \\
\text { velocidade... } \\
\text { A6: É... movimento para a bola... é quinze... /// P: } \\
\text { Quantidade de movimento da bola. } \\
\text { P: Então o que passou... tu tinha quanto antes na perna? } \\
\text { A5 e A6: Vinte. } \\
\text { P: Tu passou quinze pra bola. } \\
\text { A5: Ficou cinco na perna. ((Professor vai ajudar outro } \\
\text { grupo)). }\end{array}$} & $\begin{array}{c}\text { Definição das } \\
\text { variáveis relevantes ao } \\
\text { problema }\end{array}$ \\
\hline & & Argumentação \\
\hline & & $\begin{array}{l}\text { Classificação e } \\
\text { organização dos dados } \\
\text { Raciocínio Lógico e } \\
\text { proporcional }\end{array}$ \\
\hline
\end{tabular}

Quadro 28: Cena 2.10

O aluno 5 percebe a transferência da quantidade de movimento ("Ah:: vai ser... nós fizemos vinte coisa... né? Ela vai passar... digamos que vai passar... quinze metros por segundo... e no pé dele vai ficar cinco metros por segundo... entendeu? Vai dividir o que o professor falou... PROFESSOR...”), mas não sedimentou o termo correto conforme pontua o professor ("Não... tu passou quantidade de movimento... não velocidade..."). Esse estudante expressou também um raciocínio lógico e proporcional (“digamos... a gente tá supondo que é vinte metros por segundo... daí ele passou e ficou um pouco de movimento na perna... deixamos cinco metros por segundo... daí passou quinze metr/ para a bola." e "Ficou cinco na perna."), ao classificar e organizar os dados no processo de definição das variáveis relevantes ao problema, e seu colega (aluno 6) acompanha seu raciocínio (“É... movimento para a bola... é quinze..." e "Vinte.").

A seguir eles continuam a dedução por alguns segundos até iniciarem a questão dois (“Consequentemente, qual é a velocidade adquirida pela bola?”). 


\begin{tabular}{|c|c|c|}
\hline $\begin{array}{l}\text { Tempo inicial } \\
\text { e final da cena }\end{array}$ & Transcrição, Descrição das ações e linguagens & Ciclo Argumentativo \\
\hline \multirow[t]{3}{*}{$\begin{array}{c}00: 51: 50- \\
00: 52: 10\end{array}$} & \multirow{3}{*}{$\begin{array}{l}\text { A6: Vamos para a dois... dois dois dois... } \\
\text { A5 ((lendo a questão)): Consequentemente... qual é... qual é } \\
\text { a velocidade adquirida pelo/pela bola logo após o chute? } \\
\text { Quinze metros por segundo. } \\
\text { A6: Como? } \\
\text { A5: Quinze metros por segundo. } \\
\text { A6: Sim. }\end{array}$} & Explicação \\
\hline & & Argumentação \\
\hline & & $\begin{array}{c}\text { Justificativa } \\
\text { Previsão } \\
\text { Dedução }\end{array}$ \\
\hline
\end{tabular}

Quadro 29: Cena 2.11

Nesta cena, o grupo direciona as atenções para a segunda questão. $\mathrm{O}$ aluno 5 faz uma previsão para a resposta ("Consequentemente... qual é... qual é a velocidade adquirida pelo/pela bola logo após o chute? Quinze metros por segundo"). Tanto a sua justificativa, quanto a sua explicação estão implícitas, já que ele assume que uma parte da quantidade de movimento foi transferida do pé para a bola (cena 2.10).

É notável que esse estudante ainda confunda os conceitos de velocidade e de quantidade de movimento, apesar da correção do professor, o que dificulta a modelagem matemática do problema e mostra a sua falta de compreensão das relações entre fenômeno e representação. Isso fica claro na dedução direta da velocidade ("Quinze metros por segundo"), no lugar de deduzir o valor a partir do princípio de conservação da quantidade de movimento. O aluno 6 parece concordar com a explicação proposta por seu colega ao aceitar o valor sugerido.

A seguir, os estudantes continuam o processo de resolução por mais alguns minutos, mas não chegam a uma explicação definitiva para as respostas. Então, o professor inicia a etapa de discussão coletiva das resoluções, na qual se inicia o terceiro episódio de ensino. 


\section{Resumo do episódio 2}

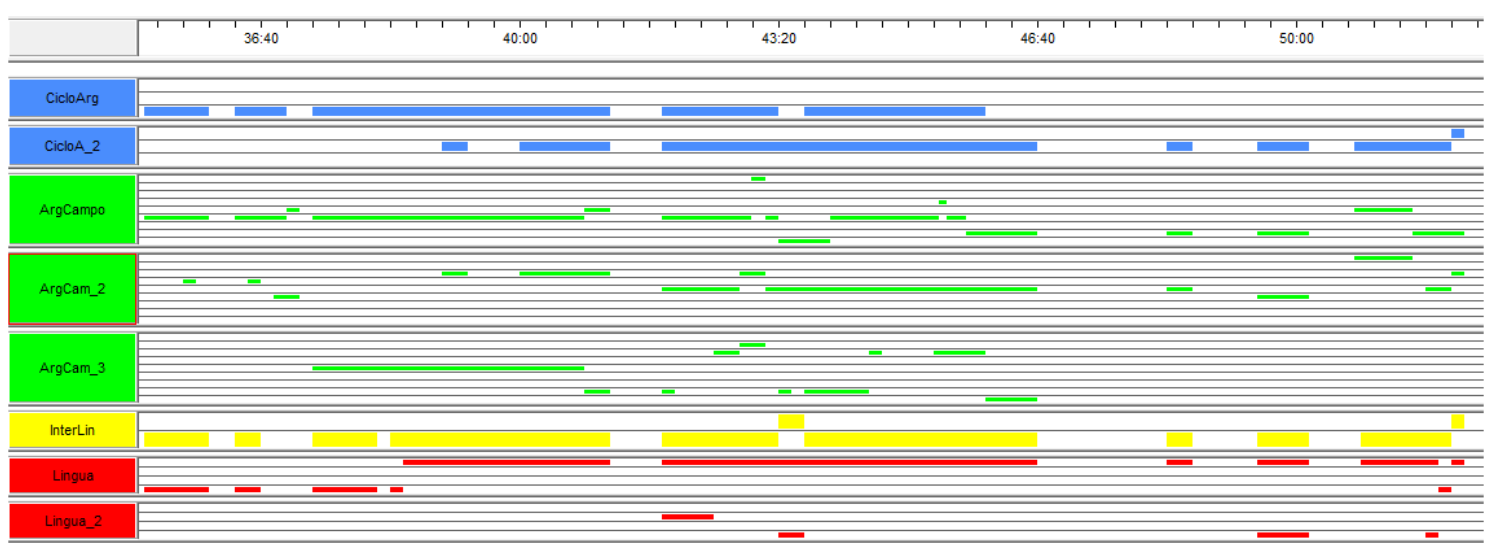

Figura 24: Resumo do episódio 2

Tal como pode ser observado na figura acima, os estudantes passam a maior parte do episódio seriando, classificando e organizando as informações, algo imprescindível para deduzir o resultado do problema aberto.

Ao longo desse processo, que se encontra no interior das etapas de cuidado com os dados e definição das variáveis relevantes do ciclo argumentativo, os discentes procuram justificar as suas estimativas e escolhas teóricas para alcançar o resultado do problema.

Fica claro também o papel da linguagem matemática na discussão (categoria língua no gráfico), que predominou ao longo da resolução do problema aberto, cooperando com a linguagem oral na maior parte do episódio e especializando os significados no final da dedução e ao introduzir a regra da divisão para amparar esse processo, por meio de raciocínios abdutivos (cenas 2.6, 2.7 e 2.9).

Destacamos ainda que o processo de resolução também foi permeado por outras características campo-dependentes da argumentação (por exemplo, raciocínios lógicos e proporcionais e previsões), no qual foi observada uma grande quantidade de justificativas, que resumimos no quadro 30 a seguir para facilitar a discussão da qualidade argumentativa. Além disso, apresentamos também as dificuldades encontradas pelos alunos para usar a linguagem matemática na resolução do problema.

Não houve raciocínios indutivos pela natureza da atividade, ou melhor, trata-se de um momento de aplicação do conhecimento para alcançar um resultado, o que coloca em foco os processos dedutivos (tal como pode ser visto no gráfico acima). Isso também se repete nos episódios posteriores. 


\begin{tabular}{|c|c|c|}
\hline Cena & Qualidade argumentativa & Conhecimento matemática demandado \\
\hline 2.1 & $\begin{array}{l}\text { Conteúdo: A2 usa noção empírica de peso. } \\
\text { Forma: A6 rechaça a ideia de A3 por ela ser } \\
\text { mulher. A5 mantém o foco na discussão. }\end{array}$ & $\begin{array}{l}\text { Falta de compreensão da questão, o que } \\
\text { mostra a falta de compreensão do conceito de } \\
\text { conservação da quantidade de movimento. }\end{array}$ \\
\hline 2.2 & $\begin{array}{l}\text { Conteúdo: A3 justifica com base em } \\
\text { conhecimentos sistematizados e uma analogia } \\
\text { refutando as estimativas dos seus colegas. A5 } \\
\text { refuta as ideias de A2 e A6 através do seu } \\
\text { conhecimento empírico de peso e sobre os tipos } \\
\text { de bola. Forma: A6 aceita a justificativa do tipo } \\
\text { de bola, mas faz estimativa distinta para a massa } \\
\text { da bola. A1 aceita a ideia de A3, porém o resto } \\
\text { do grupo não dá ouvidos para a colega. }\end{array}$ & - \\
\hline 2.3 & $\begin{array}{l}\text { Conteúdo: A6 justifica com base na autoridade } \\
\text { do professor e dele mesmo. A1 se apropria da } \\
\text { analogia de A3 para refutar as estimativas dos } \\
\text { colegas. A5 justifica através da linguagem } \\
\text { matemática com apelo a um exemplo. Forma: } \\
\text { A2 aceita valores por comodidade. A3 se recusa } \\
\text { a participar. A6 aceita a proposta de A5. Grupo } \\
\text { não ouve a justificativa de A1, que foi apropriada } \\
\text { de A3. } \\
\end{array}$ & - \\
\hline 2.4 & - & $\begin{array}{c}\text { Intervenção do professor ajuda o grupo a } \\
\text { modelizar o problema, através da comparação } \\
\text { do modelo da lousa com o problema aberto } \\
\text { em resolução. Os estudantes tem grande } \\
\text { dificuldade de enxergar como o desenho se } \\
\text { relaciona ao problema e, consequentemente, } \\
\text { qual valor estimar. } \\
\end{array}$ \\
\hline 2.5 & $\begin{array}{l}\text { Conteúdo: A2 refuta valor de velocidade } \\
\text { baseado na noção empírica de força. A5 justifica } \\
\text { através de conhecimentos prévios sobre um } \\
\text { medidor de velocidade, pela distância e por sua } \\
\text { noção intuitiva da conservação da quantidade de } \\
\text { movimento. Forma: A6 duvida dos valores } \\
\text { estimados, mas aceita a justificativa de A5. }\end{array}$ & $\begin{array}{l}\text { A5 aparenta possuir um entendimento } \\
\text { intuitivo da conservação da quantidade de } \\
\text { movimento, mas não sabe representar isso } \\
\text { matematicamente, apesar de estimar a } \\
\text { velocidade da bola através dessa noção. }\end{array}$ \\
\hline 2.6 & - & $\begin{array}{c}\text { Alunos dividem a massa pela velocidade } \\
\text { (abdução), há a falta de compreensão de } \\
\text { como modelizar matematicamente o } \\
\text { problema. Não liga-se a noção de } \\
\text { conservação com a representação matemática } \\
\text { adequada. } \\
\end{array}$ \\
\hline 2.7 & - & $\begin{array}{l}\text { A dificuldade em relacionar fenômenos e } \\
\text { modelos matemáticos fica explicita quando } \\
\text { os alunos propõem ao docente dividir a } \\
\text { velocidade pela massa (abdução) e quando } \\
\text { eles não refletem sobre a velocidade. }\end{array}$ \\
\hline 2.8 & $\begin{array}{l}\text { Conteúdo: Professor apela para conhecimento } \\
\text { empírico de massa o que auxilia a justificativa da } \\
\text { estimava para a massa da bola. Forma: Alunos } \\
\text { aceitam a justificativa do professor com apelo ao } \\
\text { conhecimento empírico sobre massa. }\end{array}$ & $\begin{array}{l}\text { Baseado na fala do professor na cena } 2.7 \text {, os } \\
\text { estudantes utilizam a unidade correta de } \\
\text { velocidade. }\end{array}$ \\
\hline 2.9 & $\begin{array}{l}\text { Conteúdo: A1 refuta as estimativas de A5 com } \\
\text { base no conceito de distância e depois por } \\
\text { absurdo, o que leva à justificação da escolha de } \\
\text { valores menores para a velocidade. Forma: } \\
\text { grupo aceita a justificativas de A1. }\end{array}$ & $\begin{array}{c}\text { Apesar da intervenção do professor, não há } \\
\text { clareza sobre o que se está modelizando. As } \\
\text { estimativas dos alunos são referentes à bola e } \\
\text { não em relação ao jogador. }\end{array}$ \\
\hline
\end{tabular}




\begin{tabular}{|c|c|c|}
2.10 & - & $\begin{array}{c}\text { A5 demonstra compreender que há a } \\
\text { transferência de uma 'quantidade' nas } \\
\text { colisões, mas não tem clareza do conceito e } \\
\text { sua matematização. }\end{array}$ \\
\hline 2.11 & $\begin{array}{c}\text { Conteúdo: A5 justifica através da noção de } \\
\text { quantidade de movimento. Forma: A6 aceita } \\
\text { afirmativa de A5. }\end{array}$ & $\begin{array}{c}\text { A5 mistura os conceitos de quantidade de } \\
\text { movimento e velocidade. }\end{array}$ \\
\hline
\end{tabular}

Quadro 30: Qualidade argumentativa x Conhecimento matemático demandado

Observando a tabela, podemos verificar, quanto ao conteúdo da argumentação, que os estudantes buscam justificativas (incluindo refutações) em conhecimentos sistematizados (cenas 2.2, 2.3, 2.5, 2.9 e 2.11) e em seus conhecimentos prévios sobre a situação e os conceitos (cenas 2.2, 2.5 e 2.8), se valendo de analogias (cenas 2.2 e 2.3) e comparações com exemplos (cenas 2.3 e 2.9 ).

Em relação à forma como se desenvolve a argumentação, parte do grupo inicialmente descarta a participação da aluna 3 devido à questões sexistas e o aluno 1 aceita as justificativas dessa colega, mas também não é ouvido. Logo, esse aspecto machista da cultura interferiu no processo argumentativo e foi preciso a intervenção do professor na cena 2.8 para direcionar a reflexão para a justificação da massa da bola, elevando a qualidade do processo argumentativo. Apesar desse fato, os estudantes procuraram ouvir as justificativas (inclusive as refutações) dos colegas e considerá-las no processo de resolução do problema, mesmo havendo momentos de "inércia" inerentes ao processo, como na cena 2.3. em que o aluno 2 aceita as sugestões dos colegas por comodidade - um momento de 'fazer lição' segundo Jiménez-Aleixandre et. al. (2000) -, porém nas cenas subsequentes ele volta a se engajar no debate. Sendo assim, consideramos que há uma boa qualidade argumentativa ao longo desse episódio.

É interessante notar que mesmo havendo esse nível de argumentação relatado, os estudantes não constroem sozinhos a explicação, ou seja, o ciclo argumentativo não é completado - algo que só ocorre no próximo episódio com a ação do professor. Isso direciona nosso olhar ao conhecimento matemático demandado ao longo da atividade e observado em cada cena.

Já no início da cena 2.1 fica claro que o grupo tem grandes dificuldades para modelizar matematicamente o problema, não sabendo se a quantidade de movimento a ser calculada é a da bola ou do pé do jogador.

$\mathrm{Na}$ cena 2.4, apesar da explicação do professor, os estudantes tem grande dificuldade de enxergar como o desenho se relaciona ao problema e, consequentemente, qual valor estimar. Essa situação persiste ao longo da cena 2.5, na qual o aluno 5 mostra compreender a relação entre a linguagem matemática e o conceito de velocidade, 
contudo, ele tem dificuldade em fazer essa mesma 'ponte' quando se trata do conceito de quantidade de movimento.

Durante as cenas 2.6 e 2.7 e 2.9 , é evidente que os estudantes não relacionam o fenômeno às representações matemáticas (algo que já fica implícito nas cenas anteriores), ao usarem a operação de divisão, isto é, um raciocínio abdutivo, para calcular a quantidade de movimento. O aluno 5 mostra ter sedimentado a noção de conservação nas cenas 2.10 e 2.11, tal como no episódio anterior, porém, ele mistura os conceitos de velocidade e quantidade de movimento.

Nossa hipótese para explicar essa situação é que, na formalização dos conceitos, o professor fez uma passagem muito rápida entre o estudo fenomenológico proposto nas atividades 1 e 2 da SEI e a introdução dos conceitos de quantidade de movimento e sua conservação (não destacando as atividades na formalização dos conteúdos), o que dificultou esse processo de modelização matemática do problema, ou melhor, prejudicou a justificação do uso da linguagem matemática no processo de resolução.

Assim, pode-se destacar que o professor deve explicitar por meio do discurso multimodal as relações entre conceito e sua matematização, tal como observamos em Bellucco e Carvalho (2009). A introdução de uma atividade que fizesse os alunos escreverem sobre essas relações talvez ajudasse na tomada de consciência sobre esses conhecimentos.

\section{Episódio 3 - Discussão coletiva sobre os problemas abertos}

Esse episódio ocorreu no final da segunda aula dupla da SEI, após a resolução dos problemas abertos da atividade $3^{30}$, quando o professor iniciou a discussão coletiva sobre as respostas obtidas.

Ao longo dessa etapa, os grupos permaneceram organizados da mesma forma que o episódio anterior, sendo assim, os alunos do grupo de análise mantiveram a seguinte disposição:

\footnotetext{
30 "1 - Qual a máxima quantidade de movimento que você consegue transferir a uma bola durante um pênalti?"; " 2 - Consequentemente, qual é a velocidade adquirida pela bola logo após o chute?"; "3 - Toda quantidade de movimento do pé é transferida à bola? Explique"; "4 - Discuta como a matemática auxilia no entendimento e na resolução das situações descritas nos problemas anteriores".
} 


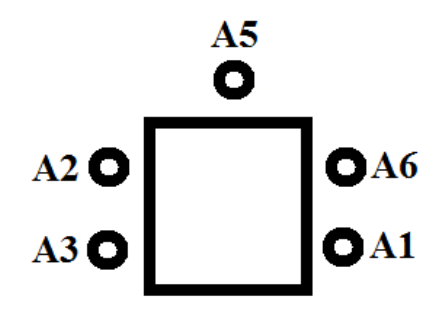

Figura 25: grupo de análise

A seguir, apresentamos a discussão da turma com o professor sobre a resolução dos problemas abertos. Inicialmente o docente retoma o problema e os passos sugeridos previamente sobre a resolução dos problemas abertos. A aluna 7 apresenta as estimativas do seu grupo sobre o primeiro problema e o professor toma esse trabalho como exemplo para a discussão, seriando, classificando e organizando as informações relevantes para a dedução e a construção da explicação.

Iniciamos a análise a partir do momento em que o docente termina a dedução do resultado para o primeiro problema aberto com a ajuda dos estudantes e introduz uma nova hipótese que gera a necessidade do uso de justificativas. O diálogo completo com as categorias identificadas encontra-se no anexo VI. Como esse episódio é pequeno, optamos por discutir a qualidade da argumentação e sua relação com o conhecimento matemático demandado no final.

\begin{tabular}{|c|c|c|}
\hline $\begin{array}{l}\text { Tempo inicial } \\
\text { e final da cena }\end{array}$ & Transcrição, Descrição das ações e linguagens & Ciclo Argumentativo \\
\hline \multirow{3}{*}{$\begin{array}{c}\text { 01:07:30 - } \\
01: 08: 20\end{array}$} & \multirow{3}{*}{$\begin{array}{l}\text { P: Então... eu diria o seguinte na hipótese... (colocaria uma } \\
\text { coisa) na hipótese... que é importantes vocês colocarem aqui } \\
\text { óh... que após a colisão... ((professor fala e escreve na } \\
\text { lousa)) a colisão de quem? } \\
\text { Alunos: Da perna com a bola. } \\
\text { P: Aqui óh... a perna fica:: } \\
\text { A7: Parada. } \\
\text { P: Parada... isso é fundamental... isso é fundamental você } \\
\text { colocar aqui... ou você colocaria 'após a colisão...' tá certo... } \\
\text { 'a perna acompanha a bola'... 'após a colisão a perna volta } \\
\text { para::' ((faz gestos com a mão representando a fala)). } \\
\text { A9: Trás. } \\
\text { P: Trás... }\end{array}$} & $\begin{array}{c}\text { Definição das } \\
\text { variáveis relevantes ao } \\
\text { problema } \\
\text { Explicação }\end{array}$ \\
\hline & & Argumentação \\
\hline & & $\begin{array}{c}\text { Hipótese } \\
\text { Justificativa }\end{array}$ \\
\hline
\end{tabular}

Quadro 31: Cena 3.1

Ao terminar a dedução do primeiro problema aberto, o docente ajuda os estudantes a introduzirem uma hipótese para justificar o resultado deduzido (perna fica parada após a colisão), definindo as variáveis relevantes ao problema e explicando a situação. Além disso, o professor sugere outras hipóteses para ilustrar as possibilidades de resultados colaborando com a explicação da situação ("ou você colocaria 'após a colisão...' tá certo... 'a perna acompanha a bola'... 'após a colisão a perna volta para::' ((faz gesto com a mão representando a fala))"). Seus gestos pontuam/cooperam com as 
informações para justificar as escolhas sobre as hipóteses. Os alunos 7 e 9 aparentam compreender a explicação (A7: Parada; A9: Trás).

\begin{tabular}{|c|c|c|}
\hline $\begin{array}{l}\text { Tempo inicial } \\
\text { e final da cena }\end{array}$ & Transcrição, Descrição das ações e linguagens & Ciclo Argumentativo \\
\hline \multirow[t]{3}{*}{$\begin{array}{c}01: 08: 20 \text { - } \\
01: 08: 30\end{array}$} & \multirow{3}{*}{$\begin{array}{l}\text { P: Se tu colocou essa condição aqui... então tu tá dizendo } \\
\text { que o 'Q' antes... } \\
\text { A9: Vai se transferir inteiro para a bola. } \\
\text { P: Daí tu vai colocar aquela assim óh:.... desenha o pé... } \\
\text { desenha a bola... isso aqui é o que? ((desenha o pé e a bola } \\
\text { na lousa antes da colisão)). O antes... esse aqui é o famoso } \\
\text { perna de pau... } \\
\text { A9: É um 'P' ou um 'b"? (((sobre o desenho do professor)). } \\
\text { P: É uma perna cara. }\end{array}$} & $\begin{array}{c}\text { Definição das } \\
\text { variáveis relevantes ao } \\
\text { problema } \\
\text { Explicação }\end{array}$ \\
\hline & & Argumentação \\
\hline & & $\begin{array}{c}\text { Dedução } \\
\text { Justificativa }\end{array}$ \\
\hline
\end{tabular}

Quadro 32: Cena 3.2

O professor reconstrói a dedução na lousa, ele usa um desenho que coopera com sua fala e a linguagem matemática na elaboração de uma justificativa sobre as hipóteses escolhidas ao longo da definição das variáveis relevantes ao problema ("Daí tu vai colocar aquela assim óh::... desenha o pé... desenha a bola... isso aqui é o que? ((desenha o pé e a bola na lousa antes da colisão))"). Isso possibilita a elaboração da explicação da situação.

O aluno 9 mostra que está acompanhando o raciocínio do docente ao completar a sua fala: "vai se transferir inteiro para a bola..." - evidenciando também que esse estudante incorporou a noção sobre conservação da quantidade de movimento. 


\begin{tabular}{|c|c|c|}
\hline $\begin{array}{l}\text { Tempo inicial } \\
\text { e final da cena }\end{array}$ & Transcrição, Descrição das ações e linguagens & Ciclo Argumentativo \\
\hline \multirow[t]{3}{*}{$\begin{array}{c}01: 08: 30- \\
01: 09: 40\end{array}$} & \multirow{3}{*}{ 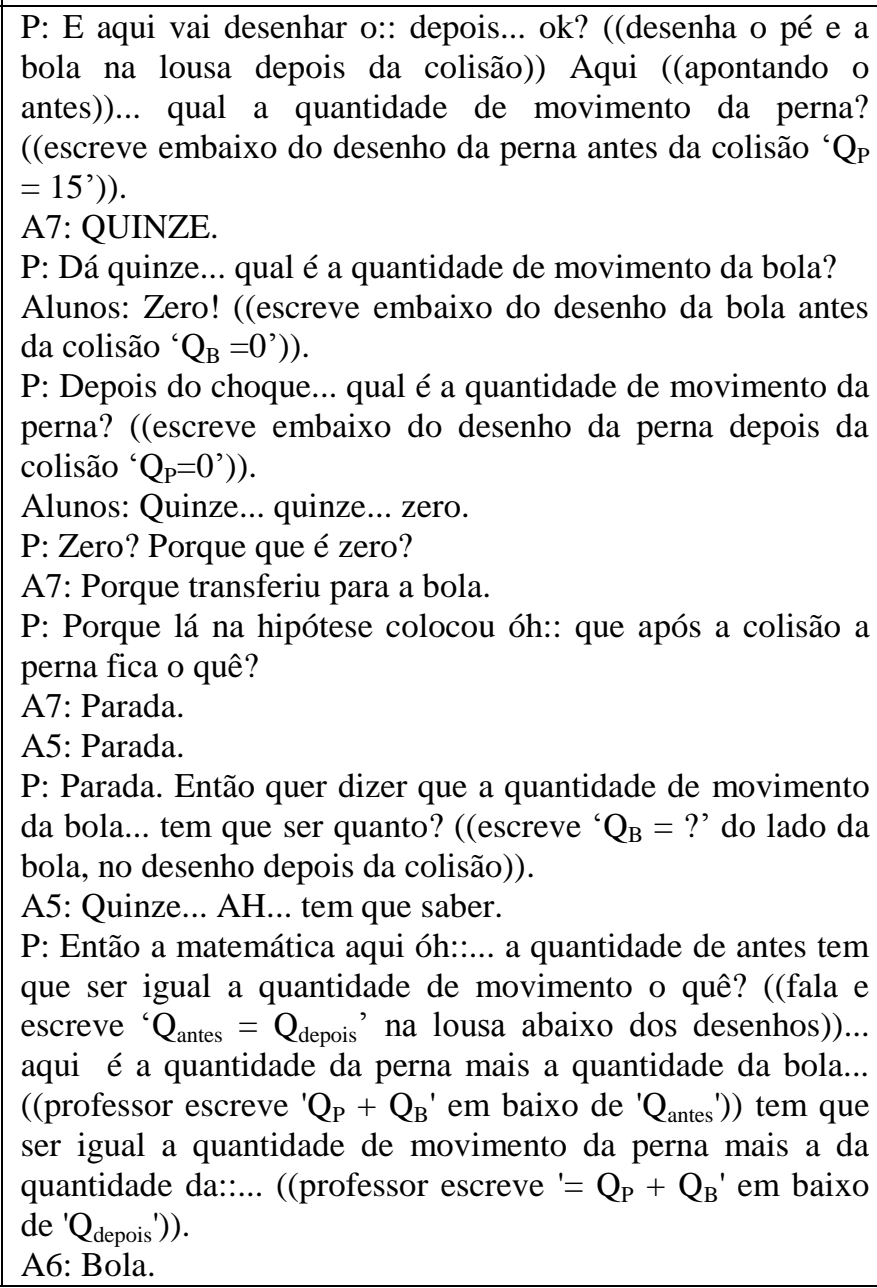 } & $\begin{array}{c}\text { Definição das } \\
\text { variáveis relevantes ao } \\
\text { problema } \\
\text { Explicação } \\
\end{array}$ \\
\hline & & Argumentação \\
\hline & & $\begin{array}{c}\text { Classificação e } \\
\text { organização dos dados } \\
\text { Dedução } \\
\text { Justificativa }\end{array}$ \\
\hline
\end{tabular}

Quadro 33: Cena 3.3

O professor, a partir da classificação e organização das informações, deduz o resultado e constrói uma explicação para os problemas abertos. Sua pergunta ("Por que é zero?"), faz a aluna 7 justificar sua afirmação ("Porque transferiu para a bola").

A linguagem matemática e a escrita cooperam com a fala do docente ("Porque lá na hipótese colocou óh:: que após a colisão a perna fica o quê?"; "Então quer dizer que a quantidade de movimento da bola... tem que ser quanto?” etc) durante a estruturação das informações (definição das variáveis relevantes ao problema), favorecendo a dedução do resultado.

É interessante notar que os alunos 5 e 6 do grupo de análise aparentam compreender a explicação do professor, acompanhando a dedução. Por outro lado, nos episódios posteriores veremos que eles têm dificuldade para modelar matematicamente os problemas. 


\begin{tabular}{|c|c|c|}
\hline $\begin{array}{l}\text { Tempo inicial } \\
\text { e final da cena }\end{array}$ & Transcrição, Descrição das ações e linguagens & Ciclo Argumentativo \\
\hline \multirow[t]{3}{*}{$\begin{array}{c}01: 09: 40- \\
01: 10: 30\end{array}$} & \multirow{3}{*}{$\begin{array}{l}\text { P: O que dá para nós simplificarmos ali... que é zero? } \\
\text { A10: Trinta... trinta. } \\
\text { P: Quantidade da bola antes é quanto? } \\
\text { A?: Quinze. } \\
\text { A6: zero ((professor faz uma seta apontando para o número } \\
\text { zero em cima da } Q_{B} \text { antes da colisão)). } \\
\text { P: DÁ BOLA. } \\
\text { A6: Ah da bola. } \\
\text { P: Qual é a quantidade do depois da perna? } \\
\text { Alunos: zero ((professor faz uma seta apontando para o } \\
\text { número zero em cima da } Q_{P} \text { depois da colisão)). } \\
\text { P: Ou seja... a quantidade de movimento da perna é igual a } \\
\text { quantidade de movimento da bola... que é de quanto? } \\
\left.\left.\text { ((escreve } Q_{P}=Q_{B}\right)\right) \text {. } \\
\text { A6: Quinze metros por segundos. } \\
\text { P: Quinze quilogramas vezes metros por:: ((completa a } \\
\left.\left.\text { escrita } Q_{P}=Q_{B}=15 \mathrm{~kg} . \mathrm{m} / \mathrm{s}\right)\right) \text {. } \\
\text { A6: Segundos. } \\
\text { P: Segundos. }\end{array}$} & $\begin{array}{c}\text { Definição das } \\
\text { variáveis relevantes ao } \\
\text { problema } \\
\text { Explicação } \\
\end{array}$ \\
\hline & & Argumentação \\
\hline & & $\begin{array}{c}\text { Classificação e } \\
\text { organização dos dados } \\
\text { Dedução }\end{array}$ \\
\hline
\end{tabular}

Quadro 34: Cena 3.4

As perguntas do docente ao longo de toda a cena 3.4, ao cooperarem com os seus desenhos e a linguagem matemática amparam a classificação e a organização dos dados no processo de definição das variáveis relevantes ao problema. Esse procedimento culmina no término da dedução levando à explicação. $\mathrm{O}$ aluno 6 mostra acompanhar o raciocínio do professor ao longo do diálogo, ao contrário do aluno 10.

\begin{tabular}{|c|c|c|}
\hline $\begin{array}{l}\text { Tempo inicial } \\
\text { e final da cena }\end{array}$ & Transcrição, Descrição das ações e linguagens & Ciclo Argumentativo \\
\hline \multirow[t]{3}{*}{$\begin{array}{c}01: 10: 30- \\
01: 12: 00\end{array}$} & \multirow{3}{*}{$\begin{array}{l}\text { P: O que seria o último aqui? Análise dos resultados... } \\
\text { ((Professor fala e escreve no quadro "5 - Análise dos } \\
\text { Resultados")) OK? Volto na pergunta lá.... qual a máxima } \\
\text { quantidade de movimento você consegue transferir... a uma } \\
\text { bola durante o pênalti?... qual a máxima quantidade de } \\
\text { movimento você consegue transferir... a uma... } \\
\text { A7: Em relação às nossas hipóteses... quinze quilograma/. } \\
\text { P: Em relação às nossas hipóteses... vou colocar aqui na } \\
\text { primeira pessoa... tá? Minha hipótese.... consigo... eu não } \\
\text { consigo... né... na verdade... é trans-fe-rida toda a quantidade } \\
\text { de movi-mento ((professor fala e escreve no quadro)). } \\
\text { ((Conversa entre A5 e A2 paralela à discussão promovida } \\
\text { pelo professor)): } \\
\text { A5: Foi o mesmo resultado que o nosso... deu quinze } \\
\text { também o nosso. } \\
\text { A2: Só que eles fizeram... um pouco mais elaborado... o } \\
\text { nosso foi mais no chute... tá ligado ((ocorrem também } \\
\text { conversas paralelas sobre a chuva)). } \\
\text { A5: Deu o mesmo resultado que o nosso. }\end{array}$} & Explicação \\
\hline & & Argumentação \\
\hline & & \\
\hline
\end{tabular}
Quadro 35: Cena 3.5

A linguagem matemática usada pelo professor especializa o resultado do segundo problema aberto, trazendo a justificativa para a explicação da resolução. A aluna 7 compreende a situação e relaciona o resultado obtido pelo docente (que é o 
mesmo do seu grupo) com a sua hipótese ("Em relação às nossas hipóteses... quinze quilograma/"), o que é um indício da sua aprendizagem.

O aluno 2 ao comparar o seu resultado com o do grupo da aluna 7, reconhece o que o raciocínio usado para responder o problema não foi adequado ("Só que eles fizeram... um pouco mais elaborado... o nosso foi mais no chute... tá ligado"). Tanto a sua fala como a do aluno 5 ("Foi o mesmo resultado que o nosso... deu quinze também o nosso" e "Deu o mesmo resultado que o nosso"), mostram que eles focam no resultado do problema em detrimento do processo.

No final da aula o professor expõe como seria a dedução se houvessem outras hipóteses.

\section{Resumo do episódio 3}

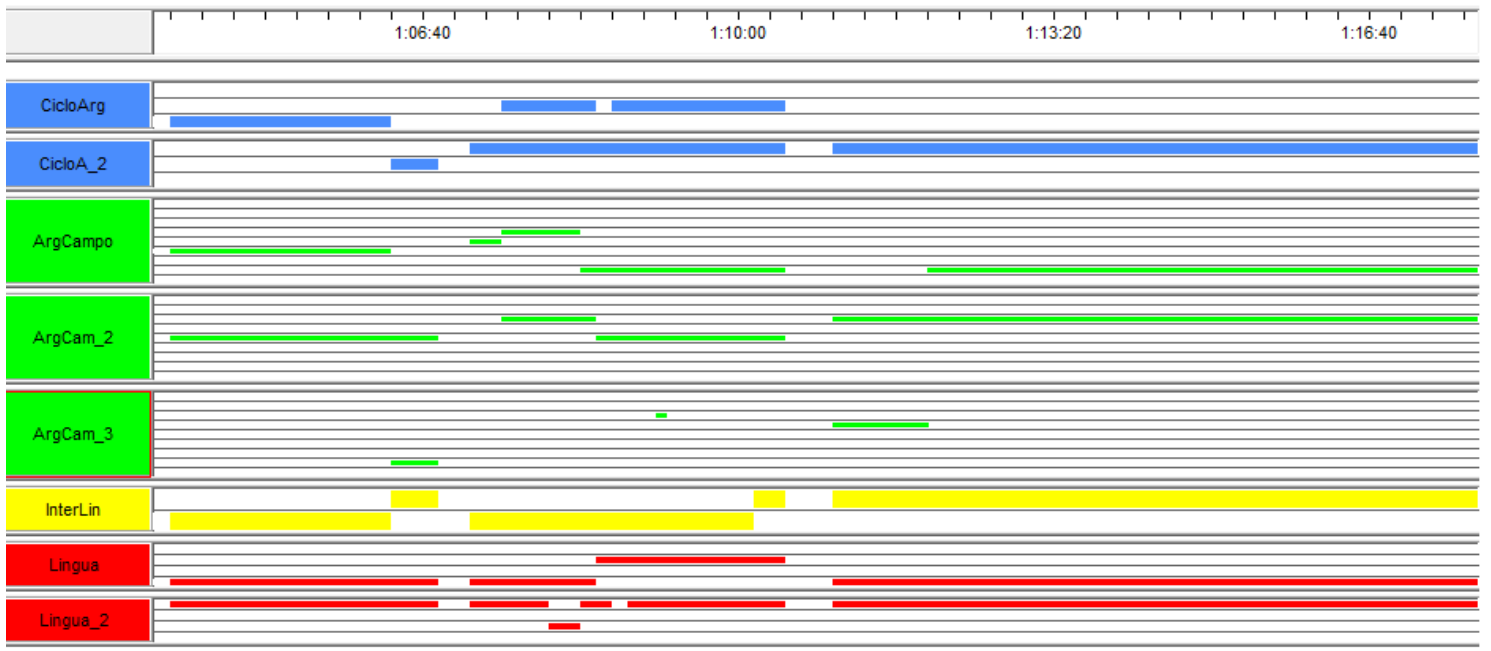

Figura 26: Resumo do episódio 3

Nesse episódio, a maioria das características argumentativas ocorre na fala do professor enquanto ele reconstrói os passos sugeridos previamente para a resolução do problema aberto com os dados do grupo da aluna 7. Dessa forma, a explicação da situação proposta foi o foco dessa situação, tal como pode ser observado na categoria CicloA_2 da figura acima. Nesse contexto, as justificativas foram determinantes para a modelização matemática do problema, possibilitando a dedução dos resultados a partir das hipóteses dadas pelo docente.

É importante ressaltar que a linguagem matemática predominou durante todas as cenas (ver categoria Lingua_2), inicialmente cooperando com a modelização 
matemática do problema (relacionando problema, desenho e hipóteses) e depois especializando a explicação (permitindo visualizar a transferência de quantidade de movimento nas diferentes hipóteses).

Sobre a qualidade argumentativa, uma vez que o docente constrói uma explicação com os questionamentos dirigidos aos alunos, conduzindo o processo, é de se esperar que ela seja boa.

Em relação ao conteúdo argumentativo, a interação entre os desenhos, os gestos, a matemática e a teoria é essencial para a justificação do processo de modelização do problema e a construção da explicação, por exemplo: "Daí tu vai colocar aquela assim óh:.... desenha o pé... desenha a bola... isso aqui é o que?”, “: Depois do choque... qual é a quantidade de movimento da perna?", "Então a matemática aqui óh:.... a quantidade de antes tem que ser igual a quantidade de movimento o quê?" etc.

Com relação à forma argumentativa, o que predomina é a fala do professor, já que esse momento da aula é destinado ao encerramento da atividade, sendo assim, apesar do docente considerar as falas e dados dos alunos no processo de justificação, sua intenção é de direcionar a discussão ("Depois do choque... qual é a quantidade de movimento da perna?", "Porque lá na hipótese colocou óh:: que após a colisão a perna fica o quê?”, “Ou seja... a quantidade de movimento da perna é igual a quantidade de movimento da bola... que é de quanto?" etc). Ao longo dessa ação, alguns estudantes parecem acompanhar a linha de raciocínio estabelecida (“A9: Vai se transferir inteiro para a bola", “A7: Porque transferiu para a bola", "A7: Parada." etc).

Quanto ao conteúdo matemático demandado, alguns estudantes aparentam compreender a modelização matemática do problema ("A9: Vai se transferir inteiro para a bola”, “A7: Porque transferiu para a bola”, “A7: Parada.” etc). Isso também pode ser observado nas cenas 3.3 e 3.4, nas quais os alunos 5, 6 e 7 respondem corretamente as questões do professor sobre o processo dedutivo.

Sendo assim, a situação física é modelizada matematicamente pelo professor possibilitando a dedução e, consequentemente, a explicação do problema, ou seja, a etapa do ciclo argumentativo que o grupo de análise não conseguiu construir no episódio anterior. Os estudantes de outro grupo (alunos 7 e 9) aparentam compreender esse processo. Já os alunos 2 e 5, ao longo da cena 2.5, não vislumbram o processo, eles apenas focam no resultado do seu grupo, que coincidentemente foi correto ("A5: Foi o mesmo resultado que o nosso... deu quinze também o nosso" e “A2: Só que eles fizeram... um pouco mais elaborado... o nosso foi mais no chute... tá ligado"). É 
interessante notar que apesar desses estudantes parecerem caminhar em direção à compreensão da relação entre os fenômenos e as representações matemáticas, as dificuldades continuam nos episódios que se seguem.

\section{Episódio 4 - Problemas abertos sobre colisões inelásticas}

Esse episódio ocorreu na quarta aula dupla da SEI, no qual o docente resolveu um exemplo de problema aberto (problema 1 da figura abaixo) para discutir o conceito de choque perfeitamente inelástico e, depois, os estudantes resolverem em pequenos grupos dois problemas abertos (problemas 2 e 3 ). Nos três choques a seguir, os objetos permanecem juntos após a colisão e dever-se-ia calcular a velocidade desse conjunto (o valor no interior dos círculos refere-se à massa dos objetos estimada pela turma em quilogramas, as velocidades estimadas estão indicadas com as setas e $\mathrm{V}_{\mathrm{f}}$ é a resposta final, ou a velocidade do conjunto, encontrada em cada problema):

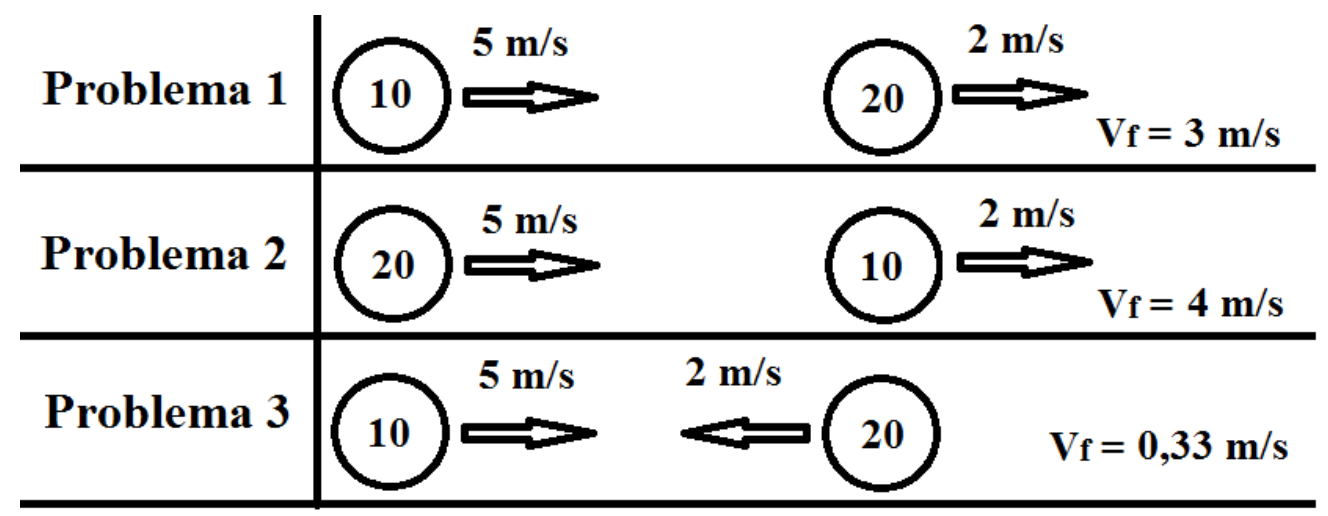

Figura 27: problemas sobre colisões inelásticas da aula 04

Os alunos do grupo de análise foram nomeados da seguinte forma:

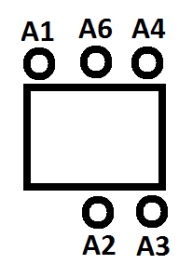

Figura 28: grupo de análise aula 04

Apresentamos a seguir a discussão do docente com todos os estudantes sobre a resolução do terceiro problema aberto. 


\begin{tabular}{|c|c|c|}
\hline $\begin{array}{c}\text { Tempo } \\
\text { inicial e final } \\
\text { da cena }\end{array}$ & Transcrição, Descrição das ações e linguagens & Ciclo Argumentativo \\
\hline \multirow[t]{3}{*}{$\begin{array}{l}00: 25: 50 \\
00: 26: 50\end{array}$} & \multirow{3}{*}{$\begin{array}{l}\text { P: Agora nós vamos fazer... uma colisão frontal... ok?... uma } \\
\text { colisão frontal... vamos:.... vamos dar uma massa aqui... } \\
\text { querem manter vinte quilos? Dez quilos? Qual vocês querem? } \\
\text { A9: Nós queremos dez. } \\
\text { P: Dez quilos? Ok. /// A10: Cinco quilos... cinco quilos. } \\
\text { P: Cinco quilogramas... } \\
\text { As: Não... oito... vinte... cinco... quarenta e nove. } \\
\text { P: Óh... xi:.... Vamos... vamos dar número redondo senão lá na } \\
\text { divisão depois a gente vai ter que... /// Alunos: Vinte... } \\
\text { quarenta...cinco... dez... } \\
\text { P: Ta ok... vou usar vinte quilogramas aqui... }\end{array}$} & $\begin{array}{l}\text { Cuidado com os dados } \\
\text { Definição das } \\
\text { variáveis relevantes ao } \\
\text { problema }\end{array}$ \\
\hline & & Argumentação \\
\hline & & $\begin{array}{c}\text { Seriação } \\
\text { Classificação e } \\
\text { organização dos dados }\end{array}$ \\
\hline
\end{tabular}

Nesta cena e na posterior, as perguntas do professor suscitam a elaboração de estimativas sobre os valores da colisão frontal, amparando também o processo de seriação, classificação e organização de informações criando condições para a posterior dedução da velocidade após a colisão inelástica.

No ciclo argumentativo, está em foco o processo de cuidado com os dados, além da definição de variáveis relevantes ao problema, no qual a linguagem algébrica tem papel fundamental ao cooperar com a linguagem oral e a esquemática para estruturar os valores das variáveis.

\begin{tabular}{|c|c|c|}
\hline $\begin{array}{c}\text { Tempo } \\
\text { inicial e final } \\
\text { da cena } \\
\end{array}$ & Transcrição, Descrição das ações e linguagens & Ciclo Argumentativo \\
\hline \multirow[t]{3}{*}{$\begin{array}{c}00: 26: 50- \\
00: 27: 50\end{array}$} & \multirow{3}{*}{$\begin{array}{l}\text { P: Só que esse carinha está vindo pra cá ((desenha uma seta no } \\
\text { corpo A apontando da esquerda para a direita)) e esse está } \\
\text { vindo pra cá ((desenha uma seta no corpo B apontando da } \\
\text { direita para a esquerda))... agora aqui eu vou apagar isso aqui } \\
\text { ((apaga a seta no desenho dos carros juntos depois da } \\
\text { colisão))... eu não vou... dizer que isso aqui está vindo para cá } \\
\text { ((faz gesto indicando o lado direito da lousa))... por que eu } \\
\text { tenho como afirmar se está vindo para cá? ((repete gesto))... } \\
\text { A9: Tenho:.... não... } \\
\text { P: Ou isso aqui está indo pra lá? ((faz gesto apontando para o } \\
\text { lado esquerdo da lousa)). } \\
\text { A9: Isso aqui está indo pra lá ((provavelmente se referindo } \\
\text { apenas a um dos objetos)). } \\
\text { P: Não... o final... o grupo... isso aqui vai andar pra esquerda } \\
\text { ou para a direita? ((faz gestos indicando as direções)). } \\
\text { Alunos: Para a direita... esquerda... no meio... } \\
\text { A7: tem que fazer a conta. } \\
\text { A10: Não... para esquerda... para esquerda ((aponta)). } \\
\text { A6: Não ele vai andar para a esquerda. } \\
\text { A?: Tem que fazer a conta professor. } \\
\text { A7: Tem que fazer a conta primeiro. } \\
\text { A6: ((inaudível))... direto... tanto para um lado quanto para o } \\
\text { outro. }\end{array}$} & $\begin{array}{l}\text { Cuidado com os dados } \\
\text { Definição das } \\
\text { variáveis relevantes ao } \\
\text { problema }\end{array}$ \\
\hline & & Argumentação \\
\hline & & $\begin{array}{c}\text { Seriação } \\
\text { Classificação e } \\
\text { organização dos dados } \\
\text { Previsão }\end{array}$ \\
\hline
\end{tabular}

$$
\text { Quadro 37: Cena } 4.2
$$

Os questionamentos do docente geram dúvidas sobre o sentido do movimento após a colisão (“por que eu tenho como afirmar se está vindo para cá?”, “Ou isso aqui 
está indo pra lá?”, “isso aqui vai andar pra esquerda ou para a direita?”). Isso favorece também a elaboração de previsões sobre o sentido do movimento dentro da etapa definição de variáveis do ciclo argumentativo ("Para a direita... esquerda... no meio...", "Não... para esquerda... para esquerda"). A linguagem esquemática coopera com a construção dos entendimentos ao longo desse processo de cuidado com os dados e de definição de variáveis relevantes ao problema.

A aluna 7 e outro colega sugerem fazer a conta para se ter certeza sobre o sentido de movimento após o choque. Não se tem certeza se eles incorporaram a matemática ao seu repertório de estratégias para estudar as colisões, ou se reproduzem o discurso do professor construído ao longo da sequência de ensino. $\mathrm{O}$ segundo caso é o mais provável já que, na cena a seguir, a aluna 7 procura inicialmente justificar suas afirmações apenas pelo conceito de velocidade, ou seja, ela apela à uma noção intuitiva na sua justificação.

\begin{tabular}{|c|c|c|}
\hline $\begin{array}{c}\text { Tempo } \\
\text { inicial e final } \\
\text { da cena }\end{array}$ & Transcrição, Descrição das ações e linguagens & Ciclo Argumentativo \\
\hline \multirow[t]{3}{*}{$\begin{array}{c}00: 27: 50- \\
00: 28: 20\end{array}$} & \multirow{3}{*}{$\begin{array}{l}\text { A10: O vinte quilos fica parado... o dez vai para a esquerda. } \\
\text { A7: Não não não não vai pra... vai pra direita... porque a } \\
\text { velocidade ali é maior óh. } \\
\text { A?: Porque a massa é menor. /// P: Olha aqui óh... } \\
\text { P: Ok... só um pouquinho... mas é só a velocidade que define } \\
\text { para onde ele vai? } \\
\text { A7: Não não não não não tem que fazer a quantidade de } \\
\text { movimento... } \\
\text { P: Tem que fazer o quê? } \\
\text { A9: A quantidade de movimento antes. } \\
\text { A7: Não antes do carro... não antes ((inaudível)). } \\
\text { A9: É:.... hã? } \\
\text { A7: É porque ele tem quantidade antes e quantidade depois. }\end{array}$} & $\begin{array}{c}\text { Definição das } \\
\text { variáveis relevantes ao } \\
\text { problema } \\
\text { Explicação }\end{array}$ \\
\hline & & Argumentação \\
\hline & & $\begin{array}{c}\text { Seriação } \\
\text { Classificação e } \\
\text { organização dos dados } \\
\text { Justificativa } \\
\text { Abdução } \\
\text { Previsão }\end{array}$ \\
\hline
\end{tabular}
Quadro 38: Cena 4.3

Inicialmente os alunos procuram justificar suas hipóteses por meio dos conceitos de massa e velocidade separadamente ("Não não não não vai pra... vai pra direita... porque a velocidade ali é maior óh", "Porque a massa é menor"), realizando previsões sobre o sentido de movimento, ajudando a seriar, classificar e organizar as informações. O aluno 10 aparenta não compreender a situação, visto que menciona que os carros irão se separar após as colisões, ou melhor, ele não compreendeu o que é uma colisão perfeitamente inelástica. Os esquemas cooperam com as falas constituindo o pano de fundo que ampara a argumentação.

A aluna 7 tenta refutar a hipótese do colega indicando que deve-se calcular a quantidade de movimento depois da colisão para se chegar ao resultado ("É porque ele tem quantidade antes e quantidade depois"). 
Ao tentarem justificar suas posições usando o conceito de massa, velocidade e quantidade de movimento os alunos realizam raciocínios abdutivos, constituindo parte da explicação dentro do ciclo argumentativo, ou seja, eles usam esses conceitos para justificar a previsão do sentido de movimento.

No caso do uso do conceito de conservação da quantidade de movimento usado pelos alunos 7 e 9 (“A9: A quantidade de movimento antes”, “A7: É porque ele tem quantidade antes e quantidade depois."), esse tipo de raciocínio foi possível devido ao estímulo do professor (“Ok... só um pouquinho... mas é só a velocidade que define para onde ele vai?"). Por outro lado, não se tem uma 'medida' do quanto os estudantes internalizam essa lei ou o quanto eles reproduzem um discurso que o professor deseja ouvir. É interessante notar ainda, que os alunos tem liberdade intelectual para expor suas opiniões, mesmo que sejam errôneas.

\begin{tabular}{|c|c|c|}
\hline $\begin{array}{c}\text { Tempo } \\
\text { inicial e final } \\
\text { da cena }\end{array}$ & Transcrição, Descrição das ações e linguagens & Ciclo Argumentativo \\
\hline \multirow[t]{3}{*}{$\begin{array}{c}00: 28: 20- \\
00: 28: 40\end{array}$} & \multirow{3}{*}{$\begin{array}{l}\text { P: Xiii::: Esse grupo aqui o que que acha? } \\
\text { A10: Vai para o lado esquerdo porque... /// P: Mas por que tu } \\
\text { acha que vai para a esquerda aluno } 10 \text { ? } \\
\text { A10: Porque vinte quilos é mais pesado se bater... se bater..../// } \\
\text { P: Mas... depende só da massa? } \\
\text { As: Não... } \\
\text { A?: A velocidade } \\
\text { A7: E a velocidade... } \\
\text { A12: Mas não vai bater. /// A13: É porque lá ((inaudível)). } \\
\text { A11: Professor... eu acho que a velocidade dobra... a } \\
\text { velocidade dobra o peso não dobra? /// A10: Ele para TRÁS... } \\
\text { ele vai para esquerda. ((vários alunos falam ao mesmo } \\
\text { tempo)). } \\
\text { P: ISSO AÍ. }\end{array}$} & $\begin{array}{c}\text { Definição das } \\
\text { variáveis relevantes ao } \\
\text { problema } \\
\text { Explicação } \\
\end{array}$ \\
\hline & & Argumentação \\
\hline & & $\begin{array}{c}\text { Justificativa } \\
\text { Previsão } \\
\text { Raciocínio lógico e } \\
\text { proporcional } \\
\text { Abdução }\end{array}$ \\
\hline
\end{tabular}

Quadro 39: Cena 4.4

Nesta cena o professor continua estimulando os alunos a justificarem suas previsões sobre a velocidade do conjunto após a colisão, direcionando o olhar para o conceito de conservação da quantidade de movimento ("Mas por que tu acha que vai para a esquerda Aluno 10?”, “...depende só da massa?”).

O aluno 10 usa a massa para justificar porque vai para a esquerda, realizando um raciocínio abdutivo ao evocar esse conceito para explicar essa situação ("Porque vinte quilos é mais pesado se bater...”). O estudante 11 também realiza uma abdução, quando prevê que a velocidade dobra em função do peso (justificativa) e realizando um raciocínio lógico e proporcional ("Professor... eu acho que a velocidade dobra... a velocidade dobra o peso não dobra?"), isto é, ele intui que o objeto de massa maior 
transfere 'mais velocidade' (ele se expressa em termos de quantidade de movimento) e a massa predomina sobre a velocidade nas colisões.

Novamente o esquema na lousa coopera com a fala na construção dos significados durante o processo de definição de variáveis do ciclo argumentativo.

\begin{tabular}{|c|c|c|}
\hline $\begin{array}{c}\text { Tempo } \\
\text { inicial e final } \\
\text { da cena } \\
\end{array}$ & Transcrição, Descrição das ações e linguagens & Ciclo Argumentativo \\
\hline \multirow[t]{3}{*}{$\begin{array}{l}00: 28: 40 \\
00: 29: 50\end{array}$} & \multirow{3}{*}{$\begin{array}{l}\text { P: ...vocês aí no fundo o que acham? } \\
\text { As: Vai para esquerda. } \\
\text { P: Grupo das meninas aqui. } \\
\text { A?: Para esquerda. } \\
\text { P: Para esquerda ou pra direita? } \\
\text { Alunos: Para esquerda. } \\
\text { A11: Eu acho que o de dez ganha. } \\
\text { P: Para esquerda... assim óh... essa dúvida nossa aqui... nós } \\
\text { vamos resolver na conta... então ficou uma ... né... uma coisa } \\
\text { óbvia para nós todos aqui... certo? Ficou uma coisa óbvia para } \\
\text { nós todos aqui... então o que vai poder responder para nós na } \\
\text { verdade vai ser o que? } \\
\text { A?: Na conta. } \\
\text { A?: A matemática. } \\
\text { P: Matemática. } \\
\text { P: Certo? } \\
\text { A9: Eu odeio ela ((em tom de brincadeira)). } \\
\text { P: Tu vai adorar ela agora... Então olha só aqui... vamos lá... } \\
\text { massa do corpo A... } \\
\text { A9: Dez... } \\
\text { P: Velocidade do corpo A. } \\
\text { A10: Cinco. } \\
\text { P: Qual é a massa do corpo B? } \\
\text { A10: (Vinte). } \\
\text { P: Qual é a velocidade do corpo B? } \\
\text { A10: Dois. } \\
\text { P: E agora vem o problema aqui... xi... }\end{array}$} & $\begin{array}{c}\text { Definição das } \\
\text { variáveis relevantes ao } \\
\text { problema } \\
\text { Explicação }\end{array}$ \\
\hline & & Argumentação \\
\hline & & $\begin{array}{c}\text { Classificação e } \\
\text { organização dos dados } \\
\text { Justificativa } \\
\text { Previsão } \\
\text { Dedução }\end{array}$ \\
\hline
\end{tabular}

\section{Quadro 40: Cena 4.5}

As intervenções do docente ("vocês aí no fundo o que acham?", "Grupo das meninas aqui”, "Para esquerda ou pra direita?") induzem os estudantes a fazerem previsões sobre o sentido de movimento ("Alunos: Para esquerda").

Em seguida, o professor enfatiza que a dúvida será resolvida com o auxílio da matemática, cuja autoridade implícita é usada como justificativa, ou seja, a proposição do uso de uma lei para resolver o problema é feita pelo docente por meio de um argumento de autoridade, o que caracteriza uma baixa qualidade argumentativa.

Em seguida, o professor inicia a dedução na lousa, pedindo para que os alunos falem os valores das variáveis estimados (classificando e organizando os dados no processo de definição de variáveis) - etapa de explicação do ciclo argumentativo. 


\begin{tabular}{|c|c|c|}
\hline $\begin{array}{c}\text { Tempo } \\
\text { inicial e final } \\
\text { da cena }\end{array}$ & Transcrição, Descrição das ações e linguagens & Ciclo Argumentativo \\
\hline \multirow[t]{3}{*}{$\begin{array}{l}00: 29: 50 \quad- \\
00: 31: 00\end{array}$} & \multirow{3}{*}{$\begin{array}{l}\text { P: Olha aqui óh... vamos relembrar lá do primeiro bimestre... } \\
\text { qual velocidade é maior... MAIS dez metros por segundo ou } \\
\text { MENOS dez metros por segundo? ((professor fala e escreve } \\
\text { os valores na lousa)). } \\
\text { A?: É a mesma. } \\
\text { P: É A MESMA? } \\
\text { A9: Eu acho que não... } \\
\text { P: Vamos... fala. } \\
\text { A8: Uma vai para um lado e outra vai para o outro. } \\
\text { P: Uma vai para um lado e a outra vai para o outro... A14... } \\
\text { concorda ou discorda? } \\
\text { A?: Concordo... } \\
\text { P: Discorda? } \\
\text { A14: Não... eu concordo. } \\
\text { P: Concorda também? Então olha aqui... isso aqui gente... é } \\
\text { fundamental... fundamental... certo? ((apontando para o } \\
\text { “+10m/s" e para o “-10m/s"))... nós reconhecermos que } \\
\text { quando eu tenho sentidos opostos ((junta os dois dedos } \\
\text { indicadores formando uma linha reta))...eu tenho que usar } \\
\text { sinais... diferentes... SE eu não fizer isso á... a minha } \\
\text { ferramenta matemática... em vez de me ajudar... vai me... } \\
\text { atrapalhar... então olha só... qual é o detalhe aqui... SE ESSE } \\
\text { corpo está indo pra esquerda ((aponta para o corpo B))... }\end{array}$} & $\begin{array}{c}\text { Definição das } \\
\text { variáveis relevantes ao } \\
\text { problema } \\
\text { Explicação }\end{array}$ \\
\hline & & Argumentação \\
\hline & & $\begin{array}{c}\text { Classificação e } \\
\text { organização dos dados }\end{array}$ \\
\hline
\end{tabular}
Quadro 41: Cena 4.6

Neste ponto, o docente inicia digressão sobre o sentido de movimento e o sinal da velocidade (“... vamos relembrar lá do primeiro bimestre... qual velocidade é maior... MAIS dez metros por segundo ou MENOS dez metros por segundo?”) e os alunos relembram que o sinal indica a orientação ("É a mesma”, "Eu acho que não...”, "Uma vai para um lado e outra vai para o outro"). Isso ajuda a classificar e organizar as informações necessárias para a dedução do resultado e sua interpretação no processo de definição das variáveis relevantes e de explicação da situação.

Vale ressaltar que o desenho, os gestos e a linguagem algébrica especializam os significados sobre o sentido de movimento e sua relação com sinal da velocidade. 


\begin{tabular}{|c|c|c|}
\hline $\begin{array}{c}\text { Tempo } \\
\text { inicial e final } \\
\text { da cena }\end{array}$ & Transcrição, Descrição das ações e linguagens & $\begin{array}{c}\text { Ciclo } \\
\text { Argumentativo }\end{array}$ \\
\hline \multirow[t]{3}{*}{$\begin{array}{l}00: 31: 00 \\
00: 32: 40\end{array}$} & \multirow{3}{*}{$\begin{array}{l}\text { P: A velocidade dele então é ne-ga- } \\
\text { A6: Tiva ((completando a fala do professor.))... } \\
\text { P: Tiva... então aqui tu vai ter que abrir um parênteses e colocar o } \\
\text { sinal de ne-ga- ((professor fala e escreve ao longo dessa cena)). } \\
\text { A10: Tivo. } \\
\text { P: Tivo... legal? Então olha lá... Dez vezes cinco? } \\
\text { A6: Cinquenta. } \\
\text { P: VINTE vezes dois? } \\
\text { A6: Quarenta. } \\
\text { A?: Quarenta. } \\
\text { A7: Menos quarenta. } \\
\text { A6: Menos quarenta. } \\
\text { P: Mas... mais com menos vai dá quando? } \\
\text { As: Menos. } \\
\text { (A11): Por que vinte menos dois vai dar quarenta? } \\
\text { P: Menos então o que? Quarenta... isso sobra quanto então? } \\
\text { A9: Quarenta... é dez... } \\
\text { P: Dez... dividido por... } \\
\text { A9: Trinta... é zero vírgula três ((sobre o resultado da conta)). } \\
\text { P: Tá certo? Corta isso aqui... sobra quanto? } \\
\text { A10: Dois. } \\
\text { P: Um... terço... se eu dividir um por três... } \\
\text { A10: Vai dar um... } \\
\text { P: Um é menor... zero vírgula... eu vou bota... } \\
\text { A7: Vai dar uma dízima periódica... } \\
\text { P: Três vezes três... nove... sobra um... abaixa o outro zero... que } \\
\text { vai dar o que? } \\
\text { A9: Dá dízima periódica. } \\
\text { P: Dízima periódica... portanto eu fecho aqui com duas casas } \\
\text { decimais... }\end{array}$} & $\begin{array}{c}\text { Definição das } \\
\text { variáveis relevantes } \\
\text { ao problema } \\
\text { Explicação } \\
\end{array}$ \\
\hline & & Argumentação \\
\hline & & Dedução \\
\hline
\end{tabular}

Quadro 42: Cena 4.7

Nesta cena, o professor realizada a dedução com a ajuda dos estudantes, que aparentam compreender os cálculos, respondendo corretamente à suas questões. As linguagens algébrica, esquemática e gestual cooperam com a fala na obtenção do resultado ao longo da definição das variáveis relevantes ao problema e da explicação. 


\begin{tabular}{|c|c|c|}
\hline $\begin{array}{c}\text { Tempo } \\
\text { inicial e final } \\
\text { da cena }\end{array}$ & Transcrição, Descrição das ações e linguagens & Ciclo Argumentativo \\
\hline \multirow[t]{3}{*}{$\begin{array}{l}00: 32: 40 \\
00: 35: 35\end{array}$} & \multirow[b]{3}{*}{$\begin{array}{l}\text { P: Agora é o seguinte... para a direita ou para a esquerda? } \\
\text { A10: Para a esquerda. } \\
\text { A6: Para a esquerda. } \\
\text { A10: Para a esquerda. } \\
\text { A6 ((para o seu grupo)): Dá positivo. } \\
\text { P: Mas POR QUE? } \\
\text { A?: Para a Direita. } \\
\text { A11: Para a Direita. } \\
\text { A7: Para cá... porque não deu negativo. } \\
\text { P: Para direita ou para esquerda A14? Por quê? } \\
\text { A14: Para esquerda ((para e olha para lousa))... para a direita. } \\
\text { A6: Para a direita porque não deu negativo. } \\
\text { A?: Deu positivo. } \\
\text { P: Onde está o negativo aqui ((aponta para a conta))? } \\
\text { A6: Não tem negativo... então... } \\
\text { P: Então ele vai para onde? } \\
\text { A6: Para a direita. } \\
\text { As: Para direita. } \\
\text { A6: Então eu falei para direita... porque ele não tem negativo. } \\
\text { A11: Para direita. } \\
\text { P: Gente... olha só como é importante aqui óh... a análise } \\
\text { matemática... PESSOAL... Olha só aqui óh... como é } \\
\text { importante a análise matemática disso aqui pra tu chegar } \\
\text { ((professor atende a porta para um aviso evento sobre o meio } \\
\text { ambiente - em torno de 50 segundos))... pessoal... vamos } \\
\text { discutir algumas coisas... preciso que vocês colaborem... se } \\
\text { todo mundo falar ao mesmo tempo... não vai dar... olha aqui } \\
\text { óh... o grupo vai para a direita ou vai para a esquerda? } \\
\text { As: Direita } \\
\text { P: Por quêe } \\
\text { As: Porque é positivo. } \\
\text { P: A velocidade é positiva... entenderam? Agora é assim } \\
\text { óh...Vamos pegar os três exemplos... }\end{array}$} & Explicação \\
\hline & & Argumentação \\
\hline & & $\begin{array}{c}\text { Dedução } \\
\text { Justificativa }\end{array}$ \\
\hline
\end{tabular}
Quadro 43: Cena 4.8

Ao longo do diálogo desta cena, as questões do docente incentivam a discussão e a interpretação física do resultado matemático (“Agora é o seguinte... para a direita ou para a esquerda?”, “Mas POR QUE?”, “Para direita ou para esquerda A14? Por quê?”, “Onde está o negativo aqui ((aponta para a conta))?”, “Então ele vai para onde?”), conduzindo à explicação do resultado deduzido.

O aluno 6 inicialmente se confunde quanto ao sinal do resultado e à direção de movimento ("Para a esquerda", "Dá positivo"). Depois, ele relaciona corretamente o sinal do resultado ao sentido de movimento ("Para a direita porque não deu negativo.", "Então eu falei para direita... porque ele não tem negativo"), corrigindo o aluno 14 que disse "esquerda" e justificando sua resposta com base na estruturação matemática do problema. A linguagem algébrica especializa os significados, ou seja, permite explicar qual é o módulo da velocidade e o sentido do movimento do conjunto. 
Na sequência, inicia-se o episódio 5, no qual o professor retoma o debate sobre os três problemas abertos com o intuito de discutir o papel da matemática e sua importância na análise dos resultados, gerando uma explicação mais completa das situações, além de justificar as conclusões apresentadas.

\section{Resumo do episódio 4}

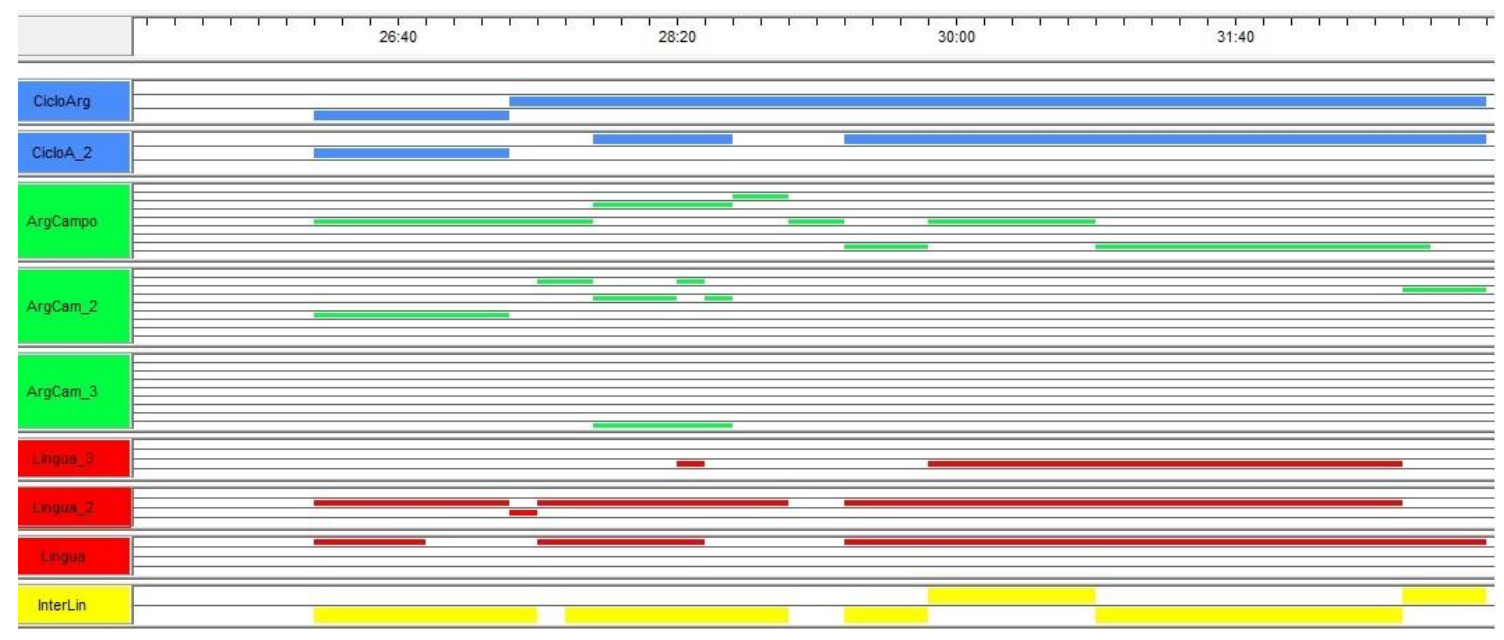

Figura 29: Resumo do episódio 4

Observando a figura 29, vemos que o processo argumentativo segue o mesmo padrão dos episódios anteriores, ou melhor, boa parte do tempo é dedicada à seriação, classificação e organização das informações ao longo das etapas de cuidado com os dados existentes (essa etapa é mais rápida, pois nesse ponto o professor sistematiza os resultados) e definição das variáveis relevantes ao problema do ciclo argumentativo.

Em relação à forma da argumentação, destaca-se a importância das perguntas do professor (“... mas é só a velocidade que define para onde ele vai?”, “Tem que fazer o quê?”, "Mas... depende só da massa?"), para que os estudantes justificassem suas alegações - algo que pode ser observado na ocorrência de diversas características campo-dependentes da argumentação (previsão, dedução, abdução, raciocínio lógico e proporcional, seriação, classificação e organização das informações).

Aqui vale destacar que as alegações são justificadas em função dessas indagações do docente e que isso desencadeou a ocorrência dessas características epistemológicas (campo-dependentes) da argumentação, tal como apontam Sandoval e Millwood (2007) para existir uma boa qualidade desse processo. Ademais, o fato de as 
justificativas só aparecerem em função dos questionamentos, não necessariamente implicam em baixa qualidade argumentativa, conforme destacam esses autores, ou seja, é provável que os alunos já tenham incorporado as alegações (dependência da massa ou da velocidade), não vendo necessidade de justificá-las. É interessante notar ainda que as diferentes linguagens (principalmente a esquemática e a algébrica) cooperaram no estabelecimento dessas características e a linguagem algébrica especializou os significados no estabelecimento da explicação (a fala do aluno 6 na cena 4.8 ilustra bem esse fato: "Então eu falei para direita... porque ele não tem negativo").

Especificamente sobre os conteúdos da argumentação destacamos:

- Ao longo das cenas 4.3 e 4.4, ocorreram algumas abduções usando os conceitos de massa e velocidade, o que indica que a compreensão da conservação da quantidade de movimento não foi apropriada pelos estudantes, já que os conceitos que eles usaram são intuitivos.

- Na cena 4.2, a aluna 7 provavelmente reproduz o discurso do professor para afirmar que deve ser feita a conta para se prever a direção de movimento após a colisão. Já na cena 4.3, antes de justificar usando a conservação da quantidade de movimento refutando a alegação do aluno 9 (que firmou que só tinha que calcular a quantidade de movimento antes), ela (A7) usa o conceito de velocidade. Seus colegas também apelam ao conceito de massa. E ainda, o aluno 10 não compreende fisicamente a situação proposta (colisão perfeitamente inelástica) e justifica de forma confusa recorrendo ao conceito de massa.

- Na cena 4.4, o aluno 10 continua justificando por meio da massa e a aluna 7 e outro colega usam a velocidade, estimulados pela questão do professor (que direciona as atenções para o uso simultâneo dos dois conceitos). O aluno 11 apela a um raciocínio lógico e proporcional para associar os dois conceitos.

- Durante a cena 4.5, a autoridade do professor é usada para justificar o uso da matemática, a fala do aluno 9 ("Eu odeio ela") evidencia que a falta de compreensão do porque ela tem esse papel, gera um desconforto na turma.

- Ao longo da cena 4.8, os alunos justificam a direção de movimento dos corpos após a colisão por meio do sinal do resultado (positivo o móvel vai para a direita).

Sendo assim, as justificativas apelam aos conceitos intuitivos de massa e velocidade. Ao mesmo tempo, apropriação do conceito de conservação da quantidade 
de movimento não parece ter força entre os estudantes (tal como foi observado na aluna 7). Isso implica na redução da qualidade argumentativa, já que as referências epistemológicas estudadas não são usadas plenamente para coordenar alegações e evidências, tal como pontuam Sampson e Clark (2006) para esse tipo de situação.

Ainda quanto a questão dos conteúdos da qualidade argumentativa, apesar dos estudantes não terem incorporado plenamente o conceito de conservação, eles aceitam a justificativa de autoridade do professor em relação ao papel da matemática na dedução do resultado e interpretam corretamente a direção de movimento (para direita) no final da cena 4.8. Sendo assim, considerando o que classificamos como conteúdos para coordenação de alegações e evidências, é importante o uso de várias formas de garantias (SANDOVAL e MILWOOD, 2007), tal como a matemática foi usada no final desse episódio. Em oposição a essa situação, levando em conta a nossa categoria de forma para coordenação de alegações e evidências, esse fato é de baixa qualidade, visto que a autoridade docente é que possibilitou a justificativa, no lugar do entendimento da importância do papel da matemática na estruturação e compreensão da situação. Portanto, não houve plena apropriação do conhecimento matemático intrínseco aos conceitos de quantidade de movimento e sua conservação - os estudantes tiveram dificuldades para visualizar a dependência simultânea da massa e da velocidade nas colisões e como a matemática possibilita estruturar e interpretar essas situações.

\section{Episódio 5 - Interpretação física dos resultados matemáticos}

Ao longo deste episódio, que ocorreu logo após o anterior (na mesma aula), o professor discute com os estudantes a interpretação física dos resultados encontrados nos três problemas abertos. Seu objetivo é mostrar o papel da matemática e sua importância na análise das colisões. Ele inicia essa etapa retomando e estruturando os resultados dos problemas. 


\begin{tabular}{|c|c|c|}
\hline $\begin{array}{c}\text { Tempo } \\
\text { inicial e final } \\
\text { da cena }\end{array}$ & Transcrição, Descrição das ações e linguagens & Ciclo Argumentativo \\
\hline \multirow[t]{3}{*}{$\begin{array}{l}00: 35: 35 \\
00: 37: 00\end{array}$} & \multirow{3}{*}{$\begin{array}{l}\text { P: A primeira situação olha aqui óh... ((professor fala } \\
\text { enquanto desenha cada situação na lousa)). } \\
\text { A7: É o lado esquerdo que... } \\
\text { P: Era dez quilos e vinte quilos... a segunda era o } \\
\text { contrário...né? } \\
\text { A9: Era vinte e dez. } \\
\text { P: Vinte e dez... } \\
\text { A9: Depois é dez e vinte. } \\
\text { P: E a terceira situação aqui... } \\
\text { A?: Dez. } \\
\text { P: Dez e... vinte... } \\
\text { A9: Só que eles encontram. } \\
\text { P: Só que eles o que? } \\
\text { A9: Se encontram. } \\
\text { P: Certo? Olha aqui óh... qual é a velocidade aqui então? } \\
\text { ((referindo-se à velocidade do conjunto na primeira situação, } \\
\text { depois na segunda e na terceira situação)) três metros por } \\
\text { segundo... quatro metros por segundo... e aqui? } \\
\text { A9: Zero vírgula três três três três... ((professor anota o valor } \\
\text { na lousa)). } \\
\text { P: Esquece esse último aqui... vamos olhar esses aqui... agora } \\
\text { assim óh.... feita a análise matemática... feita a análise } \\
\text { matemática... gente... assim óh gente... o que vocês tem que } \\
\text { pensar em física? Será que minha conta está certa ou será que } \\
\text { minha conta está errada? Eu tenho que ter essa abstração... a } \\
\text { matemática pode me confirmar o resultado... mas... se eu não } \\
\text { sei o resultado... eu acho o resultado... eu tenho que o que? } \\
\text { Abstrair para ver se ele ver se ele... condiz... com mais ou } \\
\text { menos a teoria. }\end{array}$} & $\begin{array}{c}\text { Explicação } \\
\text { Cuidado com os dados } \\
\text { Definição das } \\
\text { variáveis relevantes ao } \\
\text { problema } \\
\end{array}$ \\
\hline & & Argumentação \\
\hline & & $\begin{array}{c}\text { Seriação, classificação } \\
\text { e organização dos } \\
\text { dados } \\
\text { Justificativa }\end{array}$ \\
\hline
\end{tabular}

\section{Quadro 44: Cena 5.1}

Nesta cena, o docente, com a ajuda dos estudantes, seria, classifica e organiza as informações relevantes, cuidando dos dados e definindo as variáveis relevantes, para iniciar a explicação dos problemas. A linguagem visual e a algébrica cooperam nessa estruturação da situação, que resulta na figura a seguir:

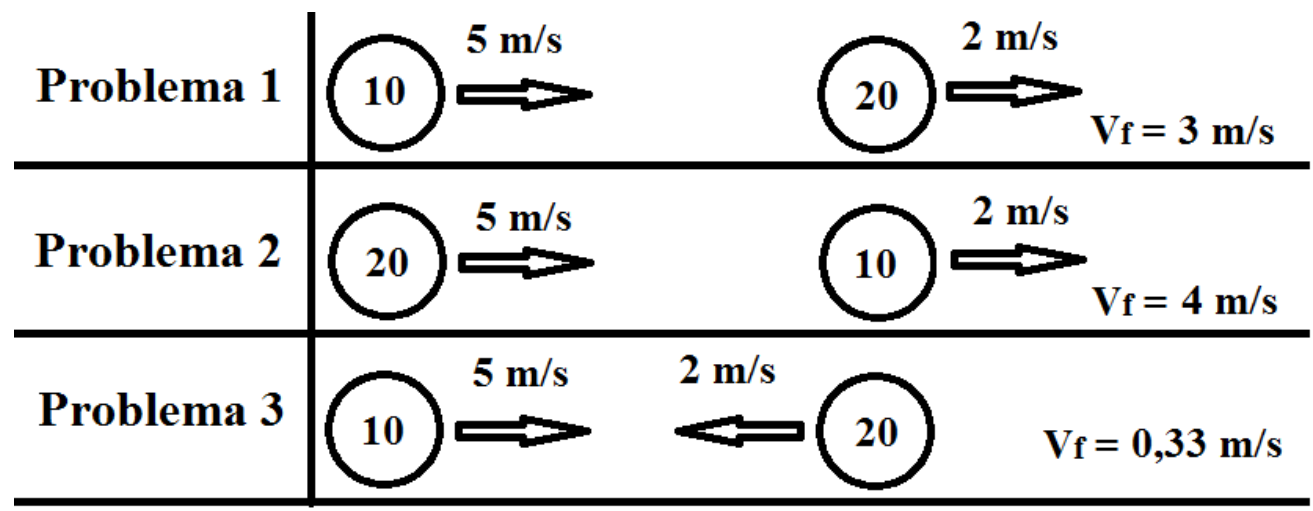

Figura 30: Estruturação dos três problemas sobre colisões inelásticas

Ele também chama atenção para a necessidade dessa interpretação física dos resultados matemáticos (“o que vocês tem que pensar em física? Será que minha conta está certa ou será que minha conta está errada? Eu tenho que ter essa abstração... a 
matemática pode me confirmar o resultado... mas... se eu não sei o resultado... eu acho o resultado... eu tenho que o que? Abstrair para ver se ele ver se ele... condiz... com mais ou menos a teoria"), ou seja, há uma justificação com base na autoridade desse conhecimento.

\begin{tabular}{|c|c|c|}
\hline $\begin{array}{c}\text { Tempo } \\
\text { inicial e final } \\
\text { da cena }\end{array}$ & Transcrição, Descrição das ações e linguagens & Ciclo Argumentativo \\
\hline \multirow[t]{3}{*}{$\begin{array}{c}00: 37: 00- \\
00: 37: 20\end{array}$} & \multirow{3}{*}{$\begin{array}{l}\text { P: Por que que esse aqui aumenta a velocidade final? ((aponta } \\
\text { para a segunda situação)). } \\
\text { A6: O que? } \\
\text { P: Por que que esse aqui aumenta a velocidade final? ((aponta } \\
\text { para a segunda situação)). } \\
\text { A6: Porque é a massa... massa } \\
\text { P: Mas o que que essa massa fez para aumentar a velocidade? } \\
\text { A7: É a massa maior com a velocidade... } \\
\text { P: O que que ela aumenta? } \\
\text { A6: O peso. } \\
\text { P: Não. } \\
\text { A7: A transfe/... a transferência. } \\
\text { A11: (Supondo) que a massa seja cinco... isso aí. }\end{array}$} & Explicação \\
\hline & & Argumentação \\
\hline & & Justificativa \\
\hline
\end{tabular}
Quadro 45: Cena 5.2

A pergunta do professor ("Por que que esse aqui aumenta a velocidade final?"), cooperativamente com a linguagem visual e a gestual, visa estimular uma justificativa para a situação, induzindo a uma explicação especializada pela linguagem algébrica da resposta obtida no problema. Dessa forma, o aluno 6 procura justificar o aumento de velocidade encontrado no segundo problema por meio da massa do primeiro corpo, que é maior que a do segundo que recebe o impacto ("Porque é a massa... massa").

A pergunta seguinte do docente ("Mas o que que essa massa fez para aumentar a velocidade?") tem por objetivo fazer os alunos refletirem sobre a influência da massa na quantidade de movimento. A aluna 7 esboça uma resposta e uma justificativa em termos da transferência ("É a massa maior com a velocidade..." e "A transfe/... a transferência."). Os alunos 6 e 11 têm dificuldade de enxergar a quantidade de movimento e justificam sobre a massa/peso ("O peso" e "(Supondo) que a massa seja cinco... isso aí."). 


\begin{tabular}{|c|c|c|}
\hline $\begin{array}{c}\text { Tempo } \\
\text { inicial e final } \\
\text { da cena }\end{array}$ & Transcrição, Descrição das ações e linguagens & Ciclo Argumentativo \\
\hline \multirow[t]{3}{*}{$\begin{array}{l}00: 37: 20 \\
00: 38: 10\end{array}$} & \multirow{3}{*}{$\begin{array}{l}\text { P: Não... mas qual é a grandeza que ela... faz aumentar... a } \\
\text { massa? } \\
\text { A6: A velocidade? } \\
\text { P: Não. } \\
\text { A9: A velocidade é a mesma. } \\
\text { ((P aponta para a letra Q na lousa)) /// A7: É porque ali... } \\
\text { primeiro... ele... segundo o exemplo é:: a massa maior... com a } \\
\text { quantidade maior... } \\
\text { A7:... igual a quantidade de movimento maior... não é isso? } \\
\text { P: Mas qual é a grandeza que tu faz aumentar quando tu } \\
\text { aumenta a massa? } \\
\text { A7: Quantidade de movimento. } \\
\text { P: Quantidade de:: movimento. /// A9: movimento } \\
\text { ((completando a fala do professor)). } \\
\text { P: Então assim óh... eu não posso... olha aqui... fazer uma } \\
\text { análise... ou só da massa... ou só da ve-lo-ci-dade... tem que } \\
\text { fazer da quantidade de movimento.... e a gente não viu que... a } \\
\text { quantidade de movimento de um corpo é transferido para o } \\
\text { outro? } \\
\text { A9: Âh hã. }\end{array}$} & Explicação \\
\hline & & Argumentação \\
\hline & & $\begin{array}{c}\text { Justificativa } \\
\text { Hipótese } \\
\text { Raciocínio lógico e } \\
\text { proporcional. }\end{array}$ \\
\hline
\end{tabular}

Quadro 46: Cena 5.3

O professor continua dirigindo o diálogo para conceito de quantidade de movimento e sua conservação ("Não... mas qual é a grandeza que ela... faz aumentar... a massa?"), e seus gestos e a linguagem algébrica especializam os significados direcionando a discussão para o conceito de quantidade de movimento.

O aluno 6 faz uma hipótese sobre a velocidade para tentar justificar o resultado encontrado (“A velocidade?”), que é refutada pelo aluno 9 (“A velocidade é a mesma”) que destaca/justifica que a velocidade é a mesma do primeiro problema, ou melhor, implicitamente ele destaca que o que mudou do primeiro problema para esse é a massa dos carros. Na sequência, a aluna 7 , por meio de um raciocínio lógico e proporcional (“É porque ali... primeiro... ele... segundo o exemplo é:: a massa maior... com a quantidade maior... igual a quantidade de movimento maior... não é isso?"), justifica que a quantidade de movimento do carro da esquerda aumentou, pois a massa é maior.

O aluno 9 (“movimento ((completando a fala do professor))", “Ãh hã”) e a aluna 7 ("Quantidade de movimento") aceitam a explicação do docente provavelmente pela autoridade do seu discurso. 


\begin{tabular}{|c|c|c|}
\hline $\begin{array}{c}\text { Tempo } \\
\text { inicial e final } \\
\text { da cena }\end{array}$ & Transcrição, Descrição das ações e linguagens & Ciclo Argumentativo \\
\hline \multirow[t]{3}{*}{$\begin{array}{l}00: 38: 10 \\
00: 39: 20\end{array}$} & \multirow{3}{*}{$\begin{array}{l}\text { P: Então aqui óh:: se eu aumentei a minha massa... eu não } \\
\text { aumentei a minha quantidade de movimento? Eu não vou } \\
\text { transferir mais movimento para o outro corpo? E qual é a } \\
\text { consequência de eu transferir mais movimento para o outro } \\
\text { corpo? } \\
\text { A9: A velocidade vai aumentar. } \\
\text { P: A velocidade vai aumentar... Por que as massas... são iguais } \\
\text { ou diferentes? } \\
\text { A7: Iguais ((em tom de dúvida)). } \\
\text { Alunos: diferentes. } \\
\text { P: Tá vendo... aumentei a minha quantidade de movimento } \\
\text { aqui ((aponta o corpo de } 20 \mathrm{~kg})) \ldots \text { ela vai ser igual lá ((aponta } \\
\text { para depois da colisão))... mas porque... mas porque minha } \\
\text { velocidade aumentou? Posso fazer a análise de/do ponto de } \\
\text { vista que... como minha massa aumentou aqui... ((aponta para } \\
\text { o móvel A da situação dois))... minha quantidade de } \\
\text { movimento aumentou ali ((aponta para depois da colisão da } \\
\text { situação dois))... mas também posso fazer a análise que minha } \\
\text { massa diminuiu aqui ((aponta para o móvel B da situação } \\
\text { dois))... consequentemente... a minha velocidade também vai } \\
\text { ser... maior ((aponta para depois da colisão da situação } \\
\text { dois))... certo? Então... eu não tenho como fazer... cuidem } \\
\text { disso aí... isso é fundamental... eu não posso fazer a análise só } \\
\text { sob o ponto de vista de massa... ou fazer só... a análise sob o } \\
\text { ponto de vista de velo-ci- } \\
\text { A?: ...dade ((completando a fala do professor)). } \\
\text { P: ...eu tenho que fazer o que... a análise sob o ponto de vista } \\
\text { dos... dois... do produto da massa vezes o que? A velocidade. }\end{array}$} & Explicação \\
\hline & & Argumentação \\
\hline & & $\begin{array}{c}\text { Justificativa } \\
\text { Raciocínio lógico e } \\
\text { proporcional. }\end{array}$ \\
\hline
\end{tabular}

Quadro 47: Cena 5.4

Aqui o professor expressa o raciocínio lógico e proporcional que justifica a explicação construída, destacando a necessidade da análise simultânea da massa e da velocidade dos objetos (“Tá vendo... aumentei a minha quantidade de movimento aqui ((aponta o corpo de $20 \mathrm{~kg})$ )... ela vai ser igual lá ((aponta para depois da colisão))... mas porque... mas porque minha velocidade aumentou? Posso fazer a análise de/do ponto de vista que... como minha massa aumentou aqui... ((aponta para o móvel A da situação dois))... minha quantidade de movimento aumentou ali ((aponta para depois da colisão da situação dois))... mas também posso fazer a análise que minha massa diminuiu aqui ((aponta para o móvel B da situação dois $)$... consequentemente... a minha velocidade também vai ser... maior ((aponta para depois da colisão da situação dois))... certo?”).

Ele continua direcionando o discurso no qual a linguagem visual e a algébrica especializam os significados sobre o que influencia as colisões. Os estudantes parecem acompanhar o seu raciocínio (“Alunos: diferentes.”, “...dade ((completando a fala do professor))"), exceto a aluna 7 que está insegura sobre a conclusão (“Iguais ((em tom de dúvida))"). 


\begin{tabular}{|c|c|c|}
\hline $\begin{array}{c}\text { Tempo } \\
\text { inicial e final } \\
\text { da cena }\end{array}$ & Transcrição, Descrição das ações e linguagens & Ciclo Argumentativo \\
\hline \multirow[t]{3}{*}{$\begin{array}{c}00: 39: 20- \\
00: 40: 30\end{array}$} & \multirow{3}{*}{$\begin{array}{l}\text { P: Olha aqui... o terceiro...que está aqui no quadro... vai pra } \\
\text { direita ou pra esquerda? Então olha... olha como vocês } \\
\text { analisaram... NÃO... vai pra direita porque a velocidade é o } \\
\text { quê? ((Falando e apontando para os valores)). } \\
\text { A9: Maior. } \\
\text { P: Maior... os outros disseram não...vai para esquerda porque a } \\
\text { massa é maior... então eu não posso analisar massa... } \\
\text { individualmente. } \\
\text { A7: Eu acho que vai para direita porque o resultado lá não deu } \\
\text { negativo. } \\
\text { A9: É... não deu negativo. } \\
\text { P: Tudo bem... nós chegamos a esse resultado... a matemática } \\
\text { que explicou isso aí... só que eu tenho que voltar... será que ta } \\
\text { certo ou errado isso aqui? Entendeu? Não adianta eu fazer } \\
\text { uma conta lá e deixar... e pronto deu isso aí... não... as vezes a } \\
\text { conta pode estar errada... "não... mas eu fiz tudo certinho" } \\
\text { ((simulando a fala de um estudante))... tudo bem... mas pode } \\
\text { ser que o teu resultado lá não condiz com o que... tu pensou... } \\
\text { então tu tem que fazer a análise... olha aqui... se tu analisar só } \\
\text { com a velocidade... esse corpo iria pra onde? Quem que é } \\
\text { maior? Direita... se eu analisar só pela massa o corpo iria para } \\
\text { onde? } \\
\text { A9: Esquerda. } \\
\text { P: Então eu não posso analisar só pela... }\end{array}$} & Explicação \\
\hline & & Argumentação \\
\hline & & \\
\hline
\end{tabular}

Quadro 48: Cena 5.5

Nesta cena, o docente discute como as hipóteses apresentadas anteriormente pelos estudantes levaram a análises errôneas, ao justificarem os sentidos de movimento isoladamente por meio dos conceitos de massa ou de velocidade. $\mathrm{O}$ aluno 9 acompanha a explicação do professor ("Maior", “É... não deu negativo”, "Esquerda”).

Sendo assim, o professor destaca a necessidade de se fazer uma análise física da situação a partir dos resultados matemáticos. Nesse contexto, a linguagem algébrica especializa o significado, isto é, indicando a direção de movimento. A aluna 7 parece aceitar esse resultado ("Eu acho que vai para direita porque o resultado lá não deu negativo"), mas a seguir ela se mostra confusa. 


\begin{tabular}{|c|c|c|}
\hline $\begin{array}{c}\text { Tempo } \\
\text { inicial e final } \\
\text { da cena }\end{array}$ & Transcrição, Descrição das ações e linguagens & Ciclo Argumentativo \\
\hline \multirow[t]{3}{*}{$\begin{array}{l}00: 40: 30 \\
00: 41: 20\end{array}$} & \multirow{3}{*}{$\begin{array}{l}\text { A7: Ele não vai se mexer então... } \\
\text { P ((interrompendo a aluna)): NÃ̃ meu anjo... o que eu estou } \\
\text { dizendo pra ti é que você não pode olhar... e analisar um } \\
\text { problema desse aí... só olhando massa ou só olhando } \\
\text { velocidade... eu tenho que analisar o que? Pela quantidade de } \\
\text { movimento... aí óh... que é o que? Massa vezes... } \\
\text { A7 e A8: A velocidade. } \\
\text { P: ISSO... ((risos pela turma)) isso aí gente é um erro } \\
\text { conceitual muito grande... eu queria que pelo menos vocês } \\
\text { tentassem... e que essa aula servisse disso aí... óh... para } \\
\text { mim... é:.... tentar mudar esse meu conceito... e não analisar } \\
\text { ou só massa ou só:: } \\
\text { A9: Velocidade. } \\
\text { P: E sim analisar a quantidade de:: } \\
\text { Alunos: Movimento. }\end{array}$} & Explicação \\
\hline & & Argumentação \\
\hline & & $\begin{array}{c}\text { Hipótese } \\
\text { Justificativa }\end{array}$ \\
\hline
\end{tabular}

A aluna 7 se equivoca na análise do problema, sua hipótese ("ele não vai se mexer então") mostra que ela pensou que a massa maior do carro lento é compensada pela velocidade maior do carro menor, fazendo os carros parar após o choque.

O professor intervém reforçando a explicação de que é necessário analisar e justificar sob o ponto de vista dos dois conceitos (massa e velocidade) ou da quantidade de movimento ("o que eu estou dizendo pra ti é que você não pode olhar... e analisar um problema desse aí... só olhando massa ou só olhando velocidade...”). Alguns alunos parecem prestar a atenção: "A7 e A8: A velocidade", "A9: Velocidade" e "Alunos: Movimento". 


\begin{tabular}{|c|c|c|}
\hline $\begin{array}{c}\text { Tempo } \\
\text { inicial e final } \\
\text { da cena }\end{array}$ & Transcrição, Descrição das ações e linguagens & Ciclo Argumentativo \\
\hline \multirow[t]{3}{*}{$\begin{array}{c}00: 41: 20- \\
00: 43: 00\end{array}$} & \multirow[b]{3}{*}{$\begin{array}{l}\text { P: O que é massa vezes velocidade... alguma pergunta? } \\
\text { Alguma dúvida? Tranquilo? } \\
\text { A7: Ô professor... por favor... } \\
\text { P: Pois não? } \\
\text { A7: É obrigado eles se mexerem? } \\
\text { P: Não. } \\
\text { A7: Eles não podem ficar paradinhos? } \\
\text { P: Claro que pode... olha aqui óh... se eu pegar... lembra que } \\
\text { eu fiz um exemplo para vocês lá...umas aulas atrás? Que eu } \\
\text { disse pra vocês que existem infinitas possibilidades? Isso aqui } \\
\text { tu pode começar hoje e ficar até fim de semana que vem } \\
\text { fazendo ((aponta para as resoluções na lousa))... vai tentando } \\
\text { as hipóteses e tu vai chegar num ponto que os corpos vão ficar } \\
\text { o quê? } \\
\text { Alunos: parados. } \\
\text { P: Parados ((choca os dois punhos, parando no meio do } \\
\text { caminho)). } \\
\text { P: Mas pra isso você tem que fazer o que? } \\
\text { A7: Hipóteses. } \\
\text { P: Hipóteses... ou então fazer uma atividade experimental... } \\
\text { né? } \\
\text { A9: Eu vou fazer isso... ((inaudível)). } \\
\text { P: Pega... pega dois carrinhos lá... óh... se tu pensar numa } \\
\text { coisa... essa quantidade de movimento tem que ser igual a essa } \\
\text { aqui ((aponta a colisão frontal exemplificada na lousa))... } \\
\text { então só pegar dois números que multiplicando da igual a dois } \\
\text { números que estão multiplicando... dez vezes cinco... qual é o } \\
\text { número que tu tem que botar aqui para multiplicar aqui } \\
\text { ((aponta os corpos que colidem frontalmente representados na } \\
\text { lousa))... dois e meio vezes vinte? Cinquenta... e aqui ((corpo } \\
\text { da frente))... } \\
\text { A9: Cinquenta. } \\
\text { P: Tá... Mas isso não vem ao caso... vai acontecer? Pode... se } \\
\text { eu pegar uma colisão... é... real... por mais que os carros } \\
\text { batam... eles nunca vão ficar parados... um vai arrastar... o } \\
\text { outro ((representa com as mãos as colisões))... não interessa se } \\
\text { for frontal ou se for o que... traseira. }\end{array}$} & Explicação \\
\hline & & Argumentação \\
\hline & & $\begin{array}{c}\text { Hipótese } \\
\text { Justificativa }\end{array}$ \\
\hline
\end{tabular}
Quadro 50: Cena 5.7

A aluna 7 reformula sua hipótese tentando refletir sobre uma situação na qual os carros de diferentes massas colidam frontalmente e permaneçam parados ("É obrigado eles se mexerem?”, “Eles não podem ficar paradinhos?”).

O professor então explica que é possível e justifica essa situação por meio do conceito de quantidade de movimento ("se tu pensar numa coisa... essa quantidade de movimento tem que ser igual a essa aqui ((aponta a colisão frontal exemplificada na lousa))... então só pegar dois números que multiplicando da igual a dois números que estão multiplicando...”). Os gestos, os desenhos e a linguagem algébrica ajudam a construir essa compreensão especializada da situação. 


\section{Resumo do episódio 5}

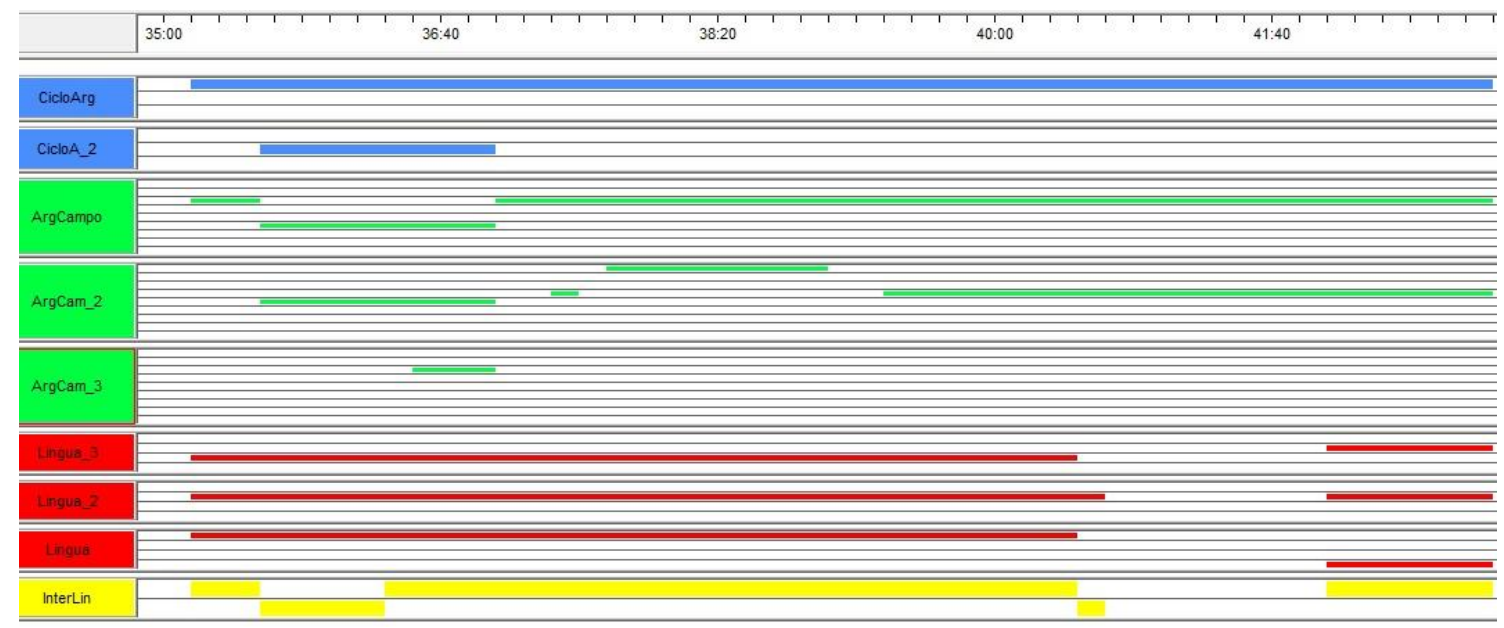

Figura 31: Resumo do episódio 5

Nesse episódio, predominou a etapa de explicação do ciclo argumentativo devido à interpretação física dos resultados matemáticos. No início, as informações são organizadas e classificadas criando o 'ambiente' no qual as hipóteses puderam ser discutidas e justificadas. Houve também o uso de raciocínios lógico e proporcionais na interpretação das colisões a partir dos conceitos de massa, velocidade e quantidade de movimento.

Destacamos ainda que a linguagem algébrica, os desenhos e os gestos especializaram a discussão sobre as hipóteses, enriquecendo as justificativas sobre o sentido de movimento dos carros após as colisões.

Em relação à forma como se desenvolve a argumentação nesse episódio, as perguntas do professor estimulam os estudantes a justificarem suas afirmações, porém, ele direciona a discussão para o uso do conceito de conservação da quantidade de movimento (predominando um discurso de autoridade), uma vez que seu objetivo é encerrar a interpretação dos problemas. Dessa forma, é a partir desses questionamentos que os alunos justificam seus argumentos, o que caracteriza baixa qualidade argumentativa segundo Sandoval e Milwood (2007). Sob a ótica de Sampson e Clark (2006) essa situação persiste, já que os estudantes ou justificam pelo conceito de velocidade ou pelo conceito de massa - foi preciso que o docente indicasse a letra " $Q$ " na lousa (cena 5.3) para que os estudantes começassem a usar o conceito de quantidade de movimento para explicar a situação. 
Quando se trata dos conteúdos da argumentação, da perspectiva dos autores citados acima, essa qualidade também é baixa, uma vez que os estudantes não se apropriaram de todos os conceitos necessários à explicação da situação, não usando a conservação da quantidade de movimento.

Esse direcionamento do discurso também parece não favorecer a compreensão dos conteúdos específicos, dado que a aluna 7, uma das alunas mais ativas e com boa base de conhecimentos (tal como pode ser observado nos episódios anteriores), apresentou dificuldades para compreender a interpretação física dos problemas (cenas 5.6 e 5.7).

Assim, como nos outros episódios, é notório como os estudantes têm dificuldade de relacionar o conteúdo específico à situação física, ou seja, eles modelizam o problema com base em conceitos mais primitivos como velocidade e massa. Parece existir um 'abismo' entre fenômenos e representações, que dificulta a utilização do conhecimento matemático demandado para a estruturação dos problemas e a posterior explicação dos resultados obtidos.

\section{Episódio 6 - O problema aberto dos astronautas}

Após o fechamento dos problemas abertos anteriores, o professor introduziu um novo problema aberto, elaborado por ele, para que os alunos resolvessem em pequenos grupos. O docente entregou aos estudantes uma folha com o seguinte problema:

Atividade 2 - PROBLEMA ABERTO

Dois astronautas, $A$ e $B$, encontram-se livres na parte externa de uma estação espacial. Qual será a velocidade do astronauta após agarrar o tanque?

Com o problema, havia uma imagem de um astronauta jogando um tanque de combustível para o outro. Apresentamos a seguir a proposição do problema e a discussão do grupo de análise. 


\begin{tabular}{|c|c|}
\hline $\begin{array}{c}\text { Tempo } \\
\text { inicial e final } \\
\text { da cena }\end{array}$ & Transcrição, Descrição das ações e linguagens \\
\hline $\begin{array}{l}0: 43: 00 \\
00: 44: 10\end{array}$ & $\begin{array}{l}\text { P: Não interessa.... muita brincadeira hoje ... beleza... gente... segunda atividade que eu } \\
\text { quero propor para vocês... certo... é assim ó... é vapt vupt... é } 5 \text { minutinhos para vocês } \\
\text { fazerem... vai rapidão... problema aberto... do astronauta aí... primeira coisa que eu } \\
\text { quero que identifique aí óh... se isso aí... é... um... choque inelástico ou não é... bom... } \\
\text { então aqui óh... rapidão... análise do problema... baixa a cabeça e faz/discuta com o } \\
\text { grupo... } \\
\text { A7: Aqui... em cinco? } \\
\text { P: Mas é rápido... } \\
\text { A7: Não é rápido. } \\
\text { P: É rápido... é só vocês se concentrarem que vocês fazem rapidinho... hipóteses... o } \\
\text { que vai usar para resolver... certo? Rapidão. }\end{array}$ \\
\hline
\end{tabular}

Nesta cena, o professor apresenta o problema aberto para os alunos resolverem em pequenos grupos.

\begin{tabular}{|c|c|c|}
\hline $\begin{array}{c}\text { Tempo } \\
\text { inicial e final } \\
\text { da cena }\end{array}$ & Transcrição, Descrição das ações e linguagens & Ciclo Argumentativo \\
\hline \multirow[t]{3}{*}{$\begin{array}{l}00: 44: 10 \\
00: 44: 40\end{array}$} & \multirow{3}{*}{$\begin{array}{l}\text { A2: É... né? Claro que é... } \\
\text { A6: O quê? } \\
\text { A2: Não... } \\
\text { A6: Primeiro temos que colocar hipóteses óh... tipo aqui... } \\
\text { qual a velocidade dele para chegar lá?... Dois metros por } \\
\text { segundos... porque ele vai estar flutuando... } \\
\text { A2: É. } \\
\text { A6: ÔH PROFESSOR... ÔH PROFESSOR. } \\
\text { A2: Tem que... perguntar se tem que contar que ele está no } \\
\text { espaço. } \\
\text { A6: Não outra coisa. } \\
\text { A2: Mas é... }\end{array}$} & $\begin{array}{l}\text { Cuidado com os dados } \\
\text { Definição das } \\
\text { variáveis relevantes ao } \\
\text { problema }\end{array}$ \\
\hline & & Argumentação \\
\hline & & $\begin{array}{c}\text { Seriação } \\
\text { Classificação e } \\
\text { organização dos dados } \\
\text { Previsão } \\
\text { Justificativa }\end{array}$ \\
\hline
\end{tabular}

Quadro 52: Cena 6.2

O grupo inicia a resolução seriando, classificando e ordenando as informações, cuidando dos dados e definindo as variáveis relevantes para a investigação ("Primeiro temos que colocar hipóteses óh... tipo aqui... qual a velocidade dele para chegar lá?...” e “Tem que... perguntar se tem que contar que ele está no espaço.”). A escrita e os desenhos cooperam nesse processo.

O aluno 6 prevê a velocidade de um dos astronautas e justifica o valor implicitamente por meio da ausência de atrito no espaço ("Dois metros por segundos... porque ele vai estar flutuando...”). 


\begin{tabular}{|c|c|c|}
\hline $\begin{array}{c}\text { Tempo } \\
\text { inicial e final } \\
\text { da cena }\end{array}$ & Transcrição, Descrição das ações e linguagens & Ciclo Argumentativo \\
\hline \multirow[t]{3}{*}{$\begin{array}{ll}00: 44: 40 & - \\
00: 46: 20 & \end{array}$} & \multirow{3}{*}{$\begin{array}{l}\text { A6: O professor... o professor... daí tipo aqui... esse aqui vai } \\
\text { estar parado... esperando esse ou os dois vão... } \\
\text { P: Tu que vai hipotetizar... o que tu entendeu do desenho? } \\
\text { A6: Eu entendi que ele tem que agarrar o galão e ver qual que } \\
\text { é a velocidade que ele tem... então... } \\
\text { A2: Então... esse daqui está parado... esse está em... } \\
\text { A6: Não... não... vamos fazer assim... esse nós coloca cinco. } \\
\text { P: Quem que atirou pra quem? } \\
\text { A6: Hã? } \\
\text { P: Quem que atirou pra quem? } \\
\text { A2: Esse jogou pra esse. } \\
\text { A6: Esse jogou pra esse. } \\
\text { A1: Do A para o B. } \\
\text { A6: Do A para o B. } \\
\text { A2: Então esse tava parado. } \\
\text { A6: Esse ta parado... o A. } \\
\text { A2: o (B) estava parado. } \\
\text { P: Eu acho que os dois estão parados... se tu ler o problema } \\
\text { bem. } \\
\text { A6: Encontram-se livre na parte externa da... então... se eles } \\
\text { estão parados e ele jogou... tem que/tem que... o máximo que } \\
\text { tem que calcular aqui é a distância. } \\
\text { P ((apontando para a folha de A6)): É só tu modelar. } \\
\text { A6: Ah... então vou colocar... aqui cinco. } \\
\text { A2: Pode usar o mesmo peso? } \\
\text { P: Oi? } \\
\text { A2: Pode usar o mesmo peso? } \\
\text { P: Tu vai hipotetizar... as tuas hipóteses tu que vai colocar. } \\
\text { A6: Não... vamos fazer assim então óh... vamos fazer assim } \\
\text { óh... aqui nós colocamos cinco e aqui dez. } \\
\text { A2: Então ta feito aqui cara... se for fazer que nem um desse } \\
\text { aqui ((aponta para o caderno)). } \\
\text { A6: Não... é para a gente fazer assim... não é pra nós copiar... } \\
\text { né oh:: ((desdenhando o colega)). } \\
\text { A2: Tipo... é modelo. } \\
\text { A6: Capaz. } \\
\text { A2: É modelo. } \\
\text { A6: Vamos fazer assim... esse aqui é de/... esse daqui é cinco e } \\
\text { esse é dez. }\end{array}$} & $\begin{array}{l}\text { Cuidado com os dados } \\
\text { Definição das } \\
\text { variáveis relevantes ao } \\
\text { problema }\end{array}$ \\
\hline & & Argumentação \\
\hline & & $\begin{array}{c}\text { Seriação } \\
\text { Classificação e } \\
\text { organização dos dados } \\
\text { Justificativa }\end{array}$ \\
\hline
\end{tabular}
Quadro 53: Cena 6.3

As etapas do ciclo argumentativo iniciadas na cena anterior continuam a ser desenvolvidas, mas agora os estudantes procuram modelar o problema enquanto seriam, classificam e organizam os dados, com o auxílio cooperativo do desenho.

O aluno 6 apresenta dificuldade para compreender o problema ("tem que... o máximo que tem que calcular aqui é a distância"), e o professor sugere que se modele a situação e deixa os estudantes livres para estimarem os valores que eles acham relevantes ("Tu vai hipotetizar... as tuas hipóteses tu que vai colocar").

Em seguida, o aluno 2 entende que modelar é copiar o problema modelo que está na lousa ("Então ta feito aqui cara... se for fazer que nem um desse aqui" e "Tipo... é 
modelo"). Apesar do aluno 6 discordar da justificativa do seu amigo, eles seguem copiando o modelo de resolução anterior ("Não... é para a gente fazer assim... não é pra nós copiar... né oh::").

Na sequência, o aluno 6 estima valores de velocidade, ignorando a indicação do professor de que os astronautas estavam parados ("Vamos fazer assim... esse aqui é de/... esse daqui é cinco e esse é dez"). Aqui fica claro que eles não se apropriaram do modelo de resolução, pois fazem uma cópia acrítica, e que não relacionam fenômenos e representações, já que não refletem se os valores estimados são coerentes.

\begin{tabular}{|c|c|c|}
\hline $\begin{array}{c}\text { Tempo } \\
\text { inicial e final } \\
\text { da cena }\end{array}$ & Transcrição, Descrição das ações e linguagens & Ciclo Argumentativo \\
\hline \multirow[t]{3}{*}{$\begin{array}{c}00: 46: 20- \\
00: 47: 00\end{array}$} & \multirow{3}{*}{$\begin{array}{l}\text { A2: Por quê cinco e dez? } \\
\text { A6: Porque sim. } \\
\text { A2: Mas porque esse é dez? } \\
\text { A6: Hã? A VELOCIDADE. } \\
\text { A2: Tá... mais por que? } \\
\text { A1: Mas os dois não vão estar na mesma velocidade? } \\
\text { A2: Mas por que que um é maior que outro? } \\
\text { A6: A VELOCIDADE DO GALÃO... ELES NÃO ESTÃO... } \\
\text { eles jogam um galão pro outro. } \\
\text { A2: Cinco metros por segundo... né? } \\
\text { A6: É... daí a gente copia tudo isso aqui e troca o cinco pelo } \\
\text { zero ((se referindo ao problema modelo)). } \\
\text { A6: Não vai fazer A3? A3 não vai fazer? } \\
\text { A2: A cara esquece... } \\
\text { A6: Ah... (fica falando para a parede). } \\
\text { A1: Tá... Como é que deu... deu agora? }\end{array}$} & $\begin{array}{l}\text { Cuidado com os dados } \\
\text { Definição das } \\
\text { variáveis relevantes ao } \\
\text { problema }\end{array}$ \\
\hline & & Argumentação \\
\hline & & $\begin{array}{c}\text { Seriação } \\
\text { Classificação e } \\
\text { organização dos dados } \\
\text { Dedução }\end{array}$ \\
\hline
\end{tabular}

Nesta cena, os alunos 1 e 2 solicitam uma justificativa para os valores estimados pelo aluno 6 ("Por quê cinco e dez?", "Mas porque esse é dez?", "Mas os dois não vão estar na mesma velocidade?" e "Mas por que que um é maior que outro?”), que tenta explicá-los, porém, não consegue justificar o porquê das velocidades escolhidas. Isso indica baixa qualidade argumentativa, visto que ele usa o tom de voz para impor sua ideia ("Hã? A VELOCIDADE”, “A VELOCIDADE DO GALÃO... ELES NÃO ESTÃO... eles jogam um galão pro outro").

Nos turnos posteriores o grupo aceita acriticamente as estimativas do aluno 6 (que favorecem a classificação e a organização de informações), que sugere usar o modelo de resolução dos problemas anteriores para deduzir a resposta ("É... daí a gente copia tudo isso aqui e troca o cinco pelo zero ((se referindo ao problema modelo))" , “Tá... Como é que deu... deu agora?”), enquanto A3 e A4 realizam conversas paralelas e não auxiliam seus colegas. 


\begin{tabular}{|c|c|c|}
\hline $\begin{array}{c}\text { Tempo } \\
\text { inicial e final } \\
\text { da cena }\end{array}$ & Transcrição, Descrição das ações e linguagens & Ciclo Argumentativo \\
\hline \multirow[t]{3}{*}{$\begin{array}{l}00: 47: 00 \\
00: 48: 00\end{array}$} & \multirow{3}{*}{$\begin{array}{l}\text { A2: Mas o peso é... vamos fazer peso dez também... né? Dez e } \\
\text { vinte... né? Hã? } \\
\text { A2: Vamos fazer o peso o mesmo. } \\
\text { A6: Como assim? } \\
\text { A2: O peso cara... o peso. } \\
\text { A6: Não, claro que não. } \\
\text { A2: Então vai ter que mudar o peso também. } \\
\text { A6: Se é cinco e se é dez... é quinze ((referindo-se à soma)). } \\
\text { A2: Ô animal... olha aqui cara... olha aqui óh...o peso... óh } \\
\text { ((apontando para a sua folha)). } \\
\text { A6: Hei... Mas olha só... mas olha só ((apontando para a folha } \\
\text { do colega))... aqui é vinte e aqui é dez... dez e vinte... trinta e } \\
\text { aqui é cinco e dez... é quinze. } \\
\text { A2: Não cara olha aqui... esse aqui é a velocidade... } \\
\text { ((apontando para a folha do colega)) eu to falando do peso. } \\
\text { A1: Tem que trocar o peso. } \\
\text { A2: O peso óh... } \\
\text { A6: AH ((expressão de que compreendeu)). } \\
\text { A2: Peso... peso peso... velocidade velocidade... aqui óh... } \\
\text { velocidade velocidade ((apontando na folha de A6))... tem que } \\
\text { ver o peso deles... } \\
\text { A2: ....por isso que eu estou perguntando... eu já arrumei.. dez } \\
\text { e vinte. } \\
\text { A6: Pode ser.... vamos fazer assim então... vamos fazer na } \\
\text { folha. } \\
\text { A2: Da uma folha aí... Vou fazer em forma de bola. }\end{array}$} & $\begin{array}{c}\text { Cuidado com os dados } \\
\text { Definição das } \\
\text { variáveis relevantes ao } \\
\text { problema } \\
\end{array}$ \\
\hline & & Argumentação \\
\hline & & $\begin{array}{c}\text { Seriação } \\
\text { Classificação e } \\
\text { organização dos dados } \\
\text { Justificativa } \\
\text { Dedução }\end{array}$ \\
\hline
\end{tabular}
Quadro 55: Cena 6.5

Ao longo das etapas de cuidado com os dados e definição das variáveis relevantes, os alunos seriam, classificam e organizam os valores, com a cooperação da linguagem algébrica e dos desenhos. $\mathrm{O}$ aluno 2, que confunde massa e peso, continua não refletindo sobre o significado físico das estimativas, dado que estabelece vinte quilogramas para a massa do astronauta (um valor absurdo para a massa de um adulto), que agarra o tanque. Isso também pode ser observado na fala do aluno 6, que procura justificar porque são quinze quilogramas (outro valor incoerente): "Hei... Mas olha só... mas olha só ((apontando para a folha do colega))... aqui é vinte e aqui é dez... dez e vinte... trinta e aqui é cinco e dez... é quinze.”.

A confusão nessa cena se dá, pois os estudantes refletem simultaneamente sobre etapas diferentes da resolução, enquanto o aluno 2 ainda está estimando valores, o aluno 6 já está modelando matematicamente o problema para fazer a dedução. Este estudante aparenta não enxergar os conceitos de massa e velocidade nas representações simbólicas - o que leva o aluno 2 a mostrar a diferença ("Peso... peso peso... velocidade velocidade... aqui óh... velocidade velocidade ((apontando na folha de A6))... tem que ver o peso deles...”). Os gestos e o desenho cooperam para justificar que o modelo de resolução do problema anterior pode ser usado na dedução do resultado do novo 
problema ("Peso... peso peso... velocidade velocidade... aqui óh... velocidade velocidade ((apontando na folha de A6))... tem que ver o peso deles..." e "Da uma folha aí... Vou fazer em forma de bola.").

\begin{tabular}{|c|c|c|}
\hline $\begin{array}{l}\text { Tempo } \\
\text { inicial e final } \\
\text { da cena } \\
\end{array}$ & Transcrição, Descrição das ações e linguagens & Ciclo Argumentativo \\
\hline \multirow[t]{3}{*}{$\begin{array}{l}00: 48: 00 \\
00: 49: 05\end{array}$} & \multirow{3}{*}{$\begin{array}{l}\text { A6: Tu vai fazer? } \\
\text { A2: Fica melhor daí... e essa outra bola vai estar indo para } \\
\text { onde? } \\
\text { A2: Para lá também? } \\
\text { A6: Fala logo guria... o que ela tá pedindo... ((sobre conversa } \\
\text { paralela de A3 e A4 sobre assuntos pessoais)). } \\
\text { A3: Curioso... né? } \\
\text { A2: Quilogramas ou quilo só? } \\
\text { A6: Quilogramas... Dez quilogramas ((fala e escreve)). } \\
\text { A2: E essa daí vai estar indo para lá e a outra também... né? } \\
\text { A2: As duas pra lá. } \\
\text { A6: Vai ficar assim e assim... né? } \\
\text { A2: Eu acho que não... se ele jogou pra esse... e esse vai } \\
\text { pegar ((faz gestos da situação))... /// A1 ((olhando para a } \\
\text { folha do A6)): Não vai para o outro lado. } \\
\text { A6: Não... as duas para lá? Então essa aqui vai ficar assim? } \\
\text { Isso? } \\
\text { A2: É } \\
\text { A1: É... os dois para o mesmo lado... Ta... o segundo é vinte? } \\
\text { A6: Tá... daí aqui no caso... a outra/a terceira bolinha. } \\
\text { A2: Que é junto. } \\
\text { A6: Que é junto... quinze. } \\
\text { A2: Tu fez o mesmo valor. } \\
\text { ((De 00:49:05 a 00:52:30 os alunos escrevem no caderno e } \\
\text { fazem conversas paralelas à atividade)) }\end{array}$} & $\begin{array}{l}\text { Cuidado com os dados } \\
\text { Definição das } \\
\text { variáveis relevantes ao } \\
\text { problema }\end{array}$ \\
\hline & & Argumentação \\
\hline & & $\begin{array}{c}\text { Seriação } \\
\text { Classificação e } \\
\text { organização dos dados } \\
\text { Hipóteses }\end{array}$ \\
\hline
\end{tabular}

Quadro 56: Cena 6.6

Ainda nas etapas de cuidado com os dados e definição das variáveis relevantes, os desenhos especializam os significados, ao definirem a direção e o sentido de movimento, auxiliando na seriação, classificação e organização dos dados. Os alunos também fazem hipóteses sobre a direção de movimento sem justificá-las. 


\begin{tabular}{|c|c|c|}
\hline $\begin{array}{c}\text { Tempo } \\
\text { inicial e final } \\
\text { da cena }\end{array}$ & Transcrição, Descrição das ações e linguagens & Ciclo Argumentativo \\
\hline \multirow[t]{3}{*}{$\begin{array}{c}00: 52: 30- \\
00: 53: 40\end{array}$} & \multirow{3}{*}{$\begin{array}{l}\text { A2: Vai dar três metros por segundo cara... } \\
\text { A6: O professor apagou o quadro ((incomodado)). } \\
\text { A2: Tem aqui óh ((aponta para a própria folha))... a primeira } \\
\text { inteirinha... vai dá... se copiar... ta com os mesmos números... } \\
\text { olha aqui óh ((aponta para a folha de A6))... tá com o mesmo } \\
\text { peso e a mesma velocidade... olha... vai dar:. treze/... vai dar } \\
\text { três segun:: três metros por segundo. } \\
\text { A1: Dá a mesma resposta que o primeiro? } \\
\text { A2: É... mesma conta. } \\
\text { A1: Traduzindo... tu pegou e... botou a primeira na um. } \\
\text { A2 ((afirmando com a cabeça)): Mais ou menos... eu não né? } \\
\text { é nós... } \\
\text { A1: É. } \\
\text { A2: Que botamos o mesmo peso e o mesmo valor. } \\
\text { A6: Tá... daí aqui nós vamos fazer. } \\
\text { A2: Vai dar a mesma coisa cara. } \\
\text { A6: Tá... calma aí... calma aí... aqui é vinte... se aqui é vinte... } \\
\text { vinte vezes cinco... vai ficar dez vezes cinco... qual é o peso } \\
\text { normal? Qual foi o peso que nós colocamos? cinco... cinco } \\
\text { metros por segundo. }\end{array}$} & $\begin{array}{c}\text { Explicação } \\
\text { Definição das } \\
\text { variáveis relevantes ao } \\
\text { problema }\end{array}$ \\
\hline & & Argumentação \\
\hline & & $\begin{array}{c}\text { Classificação e } \\
\text { organização dos dados } \\
\text { Justificativa } \\
\text { Dedução }\end{array}$ \\
\hline
\end{tabular}

Quadro 57: Cena 6.7

Nesta cena, os alunos 1 e 2 refletem sobre a modelização realizada que foi similar ao problema anterior ("Traduzindo... tu pegou e botou a primeira na um" e "Que botamos o mesmo peso e o mesmo valor."), que serviu de justificativa para as contas realizadas sem a compreensão de seu significado físico.

Dessa forma, o grupo finaliza a modelização por meio da cópia do problema modelo (classificação e organização dos dados no processo de definição das variáveis relevantes ao problema), mantendo inclusive os mesmos valores. As falas do aluno 2 ilustram bem a aceitação desses procedimentos pelo grupo: “eu não né? é nós..." e "Que botamos o mesmo peso e o mesmo valor". Nesse contexto, a linguagem escrita, a algébrica e os gestos especializam a explicação.

A seguir, os alunos continuam escrevendo nos seus cadernos e o professor inicia a discussão no grande grupo, que fica incompleta e continua na próxima aula. 


\section{Resumo do episódio 6}
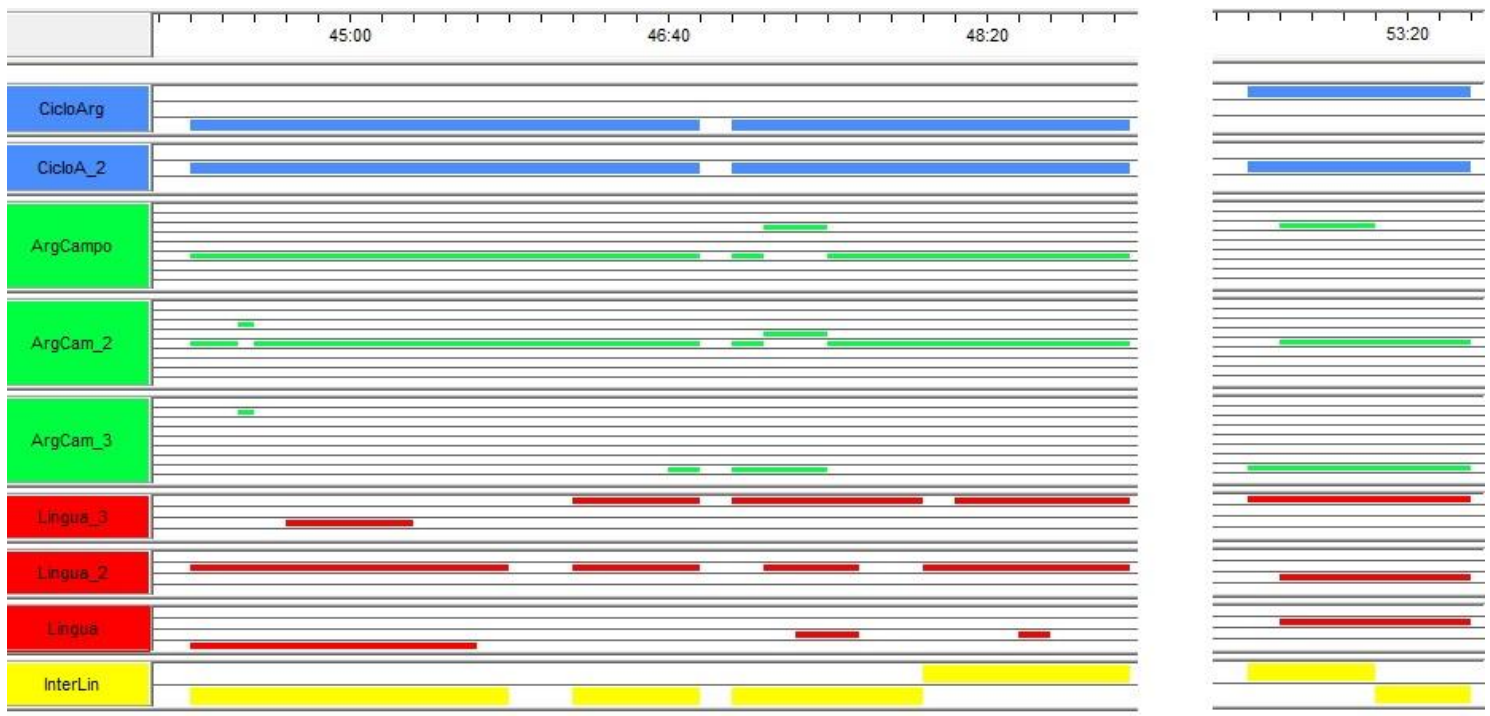

Figura 32: Resumo do episódio 6

Assim como nos episódios anteriores, ao resolver um problema, os estudantes passam boa parte do tempo seriando, classificando e organizando as informações, passando pelas etapas de cuidado com os dados e de definição de variáveis simultaneamente.

É importante frisar que as diferentes linguagens foram fundamentais para que esse contexto se desenvolvesse, predominando e cooperando por todo o episódio. Além disso, elas foram importantes no estabelecimento das justificativas e, logicamente, na dedução que levou à especialização da explicação.

É interessante notar a ocorrência completa do ciclo argumentativo e de diversas características campo-dependentes da argumentação, não é garantia de qualidade argumentativa.

Quando observamos a forma como foram coordenadas as alegações e evidências nesse episódio, verificamos: justificativas implícitas (cena 6.2), outras que se valem da autoridade de um exemplo (cenas 6.3, 6.5 e 6.7), além de momentos nos quais os estudantes não conseguem justificar suas alegações (como na cena 6.4, em que o aluno 6 impõe sua opinião pelo tom de voz e na cena 6.6, na qual os alunos não justificam suas hipóteses sobre a direção e o sentido de movimento). Dessa forma, temos uma baixa qualidade tanto pelo referencial de Sandoval e Milwood (2007) quanto pelo de Sampson e Clark (2006). 
Refletindo sobre os conteúdos para coordenar alegações e evidências, as justificativas foram baseadas no senso comum (como na cena 6.2, em que A6 justifica a velocidade implicitamente pela ausência de atrito no espaço) e se valeram, de forma acrítica, de um problema modelo (cenas 6.3, 6.5 e 6.7) - tal como pode ser evidenciado na fala do aluno 2 na cena 6.3, que entende que modelar é copiar. Isso também caracteriza uma argumentação pobre segundo o referencial supracitado.

Sendo assim, tendo em vista do conteúdo matemático demandado na construção dos argumentos científicos dos estudantes, verificamos que eles elaboram uma explicação 'mecânica', ou seja, para eles é importante chegar a um número (eles não consideraram as explanações do professor nos episódios anteriores sobre a importância da análise do problema), e não voltaram ao fenômeno no fim da dedução. Essa situação fica explícita na cena 6.5, na qual o aluno 6 estabelece o valor absurdo de vinte quilogramas para a massa do astronauta.

Dessa forma, o grupo aparentemente resolve o problema 'burocraticamente', aproximando-se do que Jiménez-Aleixandre et. al. (2000) definem como 'fazer lição'. Eles procuram um modelo para reproduzir, não refletindo sobre a dedução realizada. Portanto, destacamos a necessidade do planejamento de atividades específicas nas sequências de ensino investigativas (SEI's), que façam os estudantes realizarem uma análise crítica dos modelos matemáticos e seu significado físico. 


\section{Conclusões}

No decorrer deste trabalho, procuramos contribuir para o entendimento mais abrangente das dificuldades enfrentadas pelos estudantes no processo de construção dos conhecimentos científicos, em uma sequência de ensino investigativa. Especificamente observamos e analisamos situações argumentativas envolvendo resolução de problemas, que demandam o uso da linguagem matemática para interpretar os fenômenos físicos, e os obstáculos que se apresentam nesse processo. Buscamos responder às seguintes questões de pesquisa:

Como o conhecimento matemático é demandado na construção dos argumentos científicos dos estudantes em aulas investigativas de física?

Quais são as dificuldades enfrentadas pelos alunos ao longo desse processo?

Como a linguagem matemática torna-se necessária para a construção dos significados científicos?

Como se dá a apropriação desse conhecimento matemático?

Para responder esses questionamentos definimos por meio de uma revisão de literatura algumas categorias específicas, ou campo-dependentes, para a argumentação científica, que seriam importantes na apropriação do conhecimento matemático na sua interface com a física. Esse estudo destacou também a relevância de direcionar o foco para a qualidade da argumentação, em relação às formas como são coordenadas as alegações e as evidências e aos conteúdos pelos quais se coordenam essas alegações e evidências, com o objetivo de obter uma noção mais abrangente desse processo, que envolve ainda as diferentes linguagens demandadas ao longo das etapas do ciclo argumentativo.

As tabelas a seguir mostram que nos seis episódios analisados houve grande frequência de ocorrência das características campo-dependentes da argumentação (levantamento e teste de hipóteses, abdução, seriação, classificação e organização de informações, justificativa, previsão, dedução, indução e raciocínio lógico e proporcional): 


\begin{tabular}{|c|c|c|c|c|c|c|c|c|c|c|c|c|c|c|c|c|c|c|c|}
\hline & & \multicolumn{7}{|c|}{ Episódio 1} & \multicolumn{11}{|c|}{ Episódio 2} \\
\hline & Cenas & 1.1 & 1.2 & 1.3 & 1.4 & 1.5 & 1.6 & 1.7 & 2.1 & 2.2 & 2.3 & 2.4 & 2.5 & 2.6 & 2.7 & 2.8 & 2.9 & 2.10 & 2.11 \\
\hline \multirow{9}{*}{$\begin{array}{c}\text { Argumentação } \\
\text { Campo- } \\
\text { dependente }\end{array}$} & Seriação & & & & & & & & $\mathrm{x}$ & $\mathrm{x}$ & $\mathrm{x}$ & $\mathrm{x}$ & $\mathrm{x}$ & & $\mathrm{x}$ & $\mathrm{x}$ & $\mathrm{x}$ & & \\
\hline & $\begin{array}{c}\text { Classificação e } \\
\text { organização de } \\
\text { informações }\end{array}$ & & & & & & & & $\mathrm{x}$ & $\mathrm{x}$ & $\mathrm{x}$ & $\mathrm{x}$ & $\mathrm{x}$ & $\mathrm{x}$ & $\mathrm{x}$ & $\mathrm{x}$ & $\mathrm{x}$ & $\mathrm{x}$ & \\
\hline & $\begin{array}{c}\text { Levantamento e teste de } \\
\text { hipóteses }\end{array}$ & & & & & & & & & & & & & & & & $\mathrm{x}$ & & \\
\hline & Justificativa & & $\mathrm{x}$ & \begin{tabular}{|l|}
$x$ \\
\end{tabular} & & $\mathrm{x}$ & & $\mathrm{x}$ & \begin{tabular}{|l|}
$x$ \\
\end{tabular} & $\mathrm{x}$ & $x$ & & $\mathrm{x}$ & & & \begin{tabular}{|l|}
$x$ \\
\end{tabular} & $\mathrm{x}$ & & $\mathrm{x}$ \\
\hline & Previsão & & $\mathrm{x}$ & & & & & & & & & & $x$ & & & & & & $\mathrm{x}$ \\
\hline & Abdução & & $\mathrm{x}$ & & & $\mathrm{x}$ & & & & & & & & $\mathrm{x}$ & $\mathrm{x}$ & & $\mathrm{x}$ & & \\
\hline & Dedução & & & $\mathrm{x}$ & & $\mathrm{x}$ & $\mathrm{x}$ & $\mathrm{x}$ & & & $\mathrm{x}$ & & & $\mathrm{x}$ & $x$ & & $\mathrm{x}$ & & $\mathrm{x}$ \\
\hline & Indução & & & & & & & & & & & & & & & & & & \\
\hline & $\begin{array}{l}\text { Raciocínio lógico e } \\
\text { proporcional }\end{array}$ & & $\mathrm{x}$ & $\mathrm{x}$ & & & & $\mathrm{x}$ & & & & & $\mathrm{x}$ & & & & & $\mathrm{x}$ & \\
\hline \multirow{3}{*}{$\begin{array}{c}\text { Ciclo } \\
\text { Argumentativo }\end{array}$} & Cuidado com os dados & & & & & & & & $\mathrm{x}$ & $\mathrm{x}$ & $x$ & $\mathrm{x}$ & $\mathrm{x}$ & & $\mathrm{x}$ & & $\mathrm{x}$ & & \\
\hline & Definição das variáveis & & $\mathrm{x}$ & $\mathrm{x}$ & & $\mathrm{x}$ & $\mathrm{x}$ & & $\mathrm{x}$ & $\mathrm{x}$ & $\mathrm{x}$ & $\mathrm{x}$ & $\mathrm{x}$ & $\mathrm{x}$ & $\mathrm{x}$ & $\mathrm{x}$ & $\mathrm{x}$ & $\mathrm{x}$ & \\
\hline & Explicação & & $\mathrm{x}$ & $\mathrm{x}$ & & $\mathrm{x}$ & & $\mathrm{x}$ & & & & & & & & & & & $\mathrm{x}$ \\
\hline
\end{tabular}

Tabela 1: Argumentação campo-dependente - episódios 1 e 2

\begin{tabular}{|c|c|c|c|c|c|c|c|c|c|c|c|c|c|c|}
\hline & & \multicolumn{5}{|c|}{ Episódio 3} & \multicolumn{8}{|c|}{ Episódio 4} \\
\hline & Cenas & 3.1 & 3.2 & 3.3 & 3.4 & 3.5 & 4.1 & 4.2 & 4.3 & 4.4 & 4.5 & 4.6 & 4.7 & 4.8 \\
\hline \multirow{9}{*}{$\begin{array}{c}\text { Argumentação } \\
\text { Campo- } \\
\text { dependente }\end{array}$} & Seriação & & & & & & $\mathrm{x}$ & $\mathrm{x}$ & $\mathrm{x}$ & & & & & \\
\hline & $\begin{array}{l}\text { Classificação e } \\
\text { organização de } \\
\text { informações }\end{array}$ & & & $\mathrm{x}$ & $\mathrm{x}$ & & $\mathrm{x}$ & $\mathrm{x}$ & $\mathrm{x}$ & & $\mathrm{x}$ & $\mathrm{x}$ & & \\
\hline & $\begin{array}{c}\text { Levantamento e teste de } \\
\text { hipóteses }\end{array}$ & $\mathrm{x}$ & & & & $\mathrm{x}$ & & & & & & & & \\
\hline & Justificativa & $\mathrm{x}$ & $\mathrm{x}$ & $\mathrm{x}$ & & $\mathrm{x}$ & & & $\mathrm{x}$ & $\mathrm{x}$ & $\mathrm{x}$ & & & $\mathrm{x}$ \\
\hline & Previsão & & & & & & & $\mathrm{x}$ & $\mathrm{x}$ & $\mathrm{x}$ & $\mathrm{x}$ & & & \\
\hline & Abdução & & & & & & & & $\mathrm{x}$ & $\mathrm{x}$ & & & & \\
\hline & Dedução & & $\mathrm{x}$ & $\mathrm{x}$ & $\mathrm{x}$ & & & & & & $\mathrm{x}$ & & $\mathrm{x}$ & $\mathrm{x}$ \\
\hline & Indução & & & & & & & & & & & & & \\
\hline & $\begin{array}{c}\text { Raciocínio lógico e } \\
\text { proporcional }\end{array}$ & & & & & & & & & $\mathrm{x}$ & & & & \\
\hline & Cuidado com os dados & & & & & & $\mathrm{x}$ & $\mathrm{x}$ & & & & & & \\
\hline $\begin{array}{c}\text { Ciclo } \\
\text { Aroumentativo }\end{array}$ & Definição das variáveis & $\mathrm{x}$ & $\mathrm{x}$ & $\mathrm{x}$ & $\mathrm{x}$ & & $\mathrm{x}$ & $\mathrm{x}$ & $\mathrm{x}$ & $\mathrm{x}$ & $\mathrm{x}$ & $\mathrm{x}$ & $\mathrm{x}$ & \\
\hline & Explicação & $\mathrm{x}$ & $\mathrm{x}$ & $\mathrm{x}$ & $\mathrm{x}$ & $\mathrm{x}$ & & & $\mathrm{x}$ & $\mathrm{x}$ & $\mathrm{x}$ & $\mathrm{x}$ & $\mathrm{x}$ & $\mathrm{x}$ \\
\hline
\end{tabular}

Tabela 2: Argumentação campo-dependente - episódios 3 e 4

\begin{tabular}{|c|c|c|c|c|c|c|c|c|c|c|c|c|c|c|c|}
\hline & & \multicolumn{7}{|c|}{ Episódio 5} & \multicolumn{7}{|c|}{ Episódio 6} \\
\hline & Cenas & 5.1 & 5.2 & 5.3 & 5.4 & 5.5 & 5.6 & 5.7 & 6.1 & 6.2 & 6.3 & 6.4 & 6.5 & 6.6 & 6.7 \\
\hline \multirow{9}{*}{$\begin{array}{c}\text { Argumentação } \\
\text { Campo- } \\
\text { dependente }\end{array}$} & Seriação & $\mathrm{x}$ & & & & & & & & $\mathrm{x}$ & $\mathrm{x}$ & $\mathrm{x}$ & $\mathrm{x}$ & $\mathrm{x}$ & \\
\hline & $\begin{array}{l}\text { Classificação e } \\
\text { organização de } \\
\text { informações }\end{array}$ & $\mathrm{x}$ & & & & & & & & $\mathrm{x}$ & $\mathrm{x}$ & $\mathrm{x}$ & $\mathrm{x}$ & $\mathrm{x}$ & $\mathrm{x}$ \\
\hline & $\begin{array}{c}\begin{array}{c}\text { Levantamento e teste de } \\
\text { hipóteses }\end{array} \\
\end{array}$ & & & $\mathrm{x}$ & & $\mathrm{x}$ & $\mathrm{x}$ & $\mathrm{x}$ & & & & & & $\mathrm{x}$ & \\
\hline & Justificativa & $\mathrm{x}$ & $\mathrm{x}$ & $\mathrm{x}$ & $\mathrm{x}$ & $\mathrm{x}$ & $\mathrm{x}$ & $\mathrm{x}$ & & $\mathrm{x}$ & $\mathrm{x}$ & & $\mathrm{x}$ & & $\mathrm{x}$ \\
\hline & Previsão & & & & & & & & & $\mathrm{x}$ & & & & & \\
\hline & Abdução & & & & & & & & & & & & & & \\
\hline & Dedução & & & & & & & & & & & $\mathrm{x}$ & $\mathrm{x}$ & & $\mathrm{x}$ \\
\hline & Indução & & & & & & & & & & & & & & \\
\hline & $\begin{array}{c}\text { Raciocínio lógico e } \\
\text { proporcional }\end{array}$ & & & $\mathrm{x}$ & $\mathrm{x}$ & & & & & & & & & & \\
\hline \multirow{3}{*}{$\begin{array}{c}\text { Ciclo } \\
\text { Argumentativo }\end{array}$} & Cuidado com os dados & $\mathrm{x}$ & & & & & & & & $\mathrm{x}$ & $\mathrm{x}$ & $\mathrm{x}$ & $\mathrm{x}$ & $\mathrm{x}$ & \\
\hline & Definição das variáveis & $\mathrm{x}$ & & & & & & & & $\mathrm{x}$ & $\mathrm{x}$ & $\mathrm{x}$ & $\mathrm{x}$ & $\mathrm{x}$ & $\mathrm{x}$ \\
\hline & Explicação & $\mathrm{x}$ & $\mathrm{x}$ & $\mathrm{x}$ & $\mathrm{x}$ & $\mathrm{x}$ & $\mathrm{x}$ & $\mathrm{x}$ & & & & & & & $\mathrm{x}$ \\
\hline
\end{tabular}

Tabela 3: Argumentação campo-dependente - episódios 5 e 6 
É interessante notar que o processo argumentativo envolve necessariamente a seriação, classificação e organização das informações. Essas características são essenciais para estruturar o problema, a fim de se obter a explicação, e envolvem as etapas de cuidado com os dados e definição das variáveis relevantes ao problema do ciclo argumentativo. Apesar de não estar explícito na tabela 1, no episódio 1, essas ações foram realizadas pelo professor ao ditar o enunciado do problema fechado.

Houve ainda um intenso uso de justificativas - das 45 cenas, apenas 15 não foram justificadas - o que é importante para que se estabeleça uma situação de argumentação. Por outro lado, destacamos a seguir que o uso de justificativas não configura necessariamente uma boa qualidade desse tipo de discurso, tal como pontuado por Sandoval e Millwood (2007) e Sampson e Clark (2006).

Além disso, os alunos recorrem à previsões, à hipóteses e a raciocínios lógico e proporcionais na busca de uma explicação. É importante destacar ainda que eles muitas vezes precisaram do professor para alcançar essa última etapa do ciclo argumentativo remetendo novamente à qualidade desse discurso. Isso pode ser visto no episódio 2, no qual os estudantes não conseguem explicar resultado, então, o professor constrói a explicação no episódio 3, durante a discussão coletiva. O mesmo ocorre nos episódios 4 e 5, em que o professor conduz a discussão para elucidar as respostas dos problemas abertos sobre colisões inelásticas. Destacamos que a indução não esteve presente nos episódios analisados, pois esses envolveram a resolução de problemas, nos quais os processos dedutivos são essenciais - é provável que raciocínios indutivos tenham ocorrido quando os estudantes manipularam os pêndulos, generalizando as suas observações ao elevá-los a diferentes alturas.

Para se ter uma ideia mais profunda dessas especificidades, resumimos no quadro a seguir a argumentação campo-dependente dos seis episódios: 


\begin{tabular}{|c|c|c|c|}
\hline Episódio & $\begin{array}{l}\text { Ciclo Argumentativo e } \\
\text { Ação dos Participantes }\end{array}$ & $\begin{array}{l}\text { Argumentação Campo-Dependente, } \\
\text { Linguagens e suas Relações }\end{array}$ & $\begin{array}{l}\text { Qualidade Argumentativa, Justificativas e } \\
\text { Conhecimento Matemático Demandado }\end{array}$ \\
\hline $\begin{array}{l}\text { 1- Quem tem } \\
\text { maior } \\
\text { quantidade de } \\
\text { movimento? } \\
\text { Um problema } \\
\text { fechado }\end{array}$ & $\begin{array}{l}\text { Definição de variáveis } \\
\text { realizada pelos } \\
\text { estudantes é } \\
\text { importante para } \\
\text { estabelecer a } \\
\text { explicação. }\end{array}$ & \begin{tabular}{|c|} 
Liguagem algébrica especializa os \\
significados da dedução, que é \\
amparada pelo raciocínio lógico- \\
proporcional (mass a maior de um carro \\
compensada pela velocidade maior do \\
carro de menor massa). Abdução \\
baseada na regra de divisão. \\
\end{tabular} & $\begin{array}{l}\text { Forma: Justificativas sem a necessidade de desafios, com } \\
\text { refutações amparadas em conceitos. Alegação de A3 } \\
\text { sobre o uso do conceito de velocidade média, sem relação } \\
\text { com o argumento. Conteúdo: uso dos conceitos de massa } \\
\text { e velocidade para concluir, equívoco na regra escolhida } \\
\text { (divisão) - desconexão entre fenômenos e representação. }\end{array}$ \\
\hline $\begin{array}{c}2-\text { Problemas } \\
\text { abertos } \\
\text { (atividade } 3 \mathrm{da} \\
\text { SEI) }\end{array}$ & \begin{tabular}{|c|} 
Classificação, \\
organização e definição \\
de variáveis são \\
importantes para \\
estabelecer a \\
explicação, que foi \\
dada pelo professor.
\end{tabular} & \begin{tabular}{|} 
Linguagem algébrica coopera com a \\
linguagem oral na estruturação \\
matemática do problema, possibilitando \\
a dedução. No final, ela também \\
especializa os resultados deduzidos. \\
Abdução baseada na regra de divisão.
\end{tabular} & $\begin{array}{c}\text { Forma: Desconsideração das alegações de A3 } \\
\text { (preconceito) sobre a massa da bola e de A1 que } \\
\text { concorda com ela, alunos consideram demais justificações } \\
\text { e refutações. Conteúdo: Jusficativas com base em } \\
\text { conhecimentos sistematizados e prévios (uso de } \\
\text { analogias e exemplos). Há dificuldade de modelizar o } \\
\text { problema (não se sabe se calcula Q da bola ou do pé), } \\
\text { docente sugere comparar ao exemplo, alunos persistem } \\
\text { com a dificuldade de relacionar fenômenos e } \\
\text { representação (usam a divisão para calcular a repartição } \\
\text { de Q entre os corpos), A5 tem apenas a noção qualitativa } \\
\text { da conservação de Q. }\end{array}$ \\
\hline $\begin{array}{c}3 \text { - Discussão } \\
\text { coletiva sobre } \\
\text { os problemas } \\
\text { abertos }\end{array}$ & $\begin{array}{c}\text { Classificação, } \\
\text { organização e definição } \\
\text { de variáveis são } \\
\text { importantes para } \\
\text { estabelecer a } \\
\text { explicação - etapas } \\
\text { estruturadas pelo } \\
\text { docente. }\end{array}$ & $\begin{array}{c}\text { Linguagem algébrica, desenhos e } \\
\text { gestos cooperam com a linguagem oral } \\
\text { na dedução. Linguagem algébrica } \\
\text { especializa os resultados na verificação } \\
\text { do sentido de movimento devido à } \\
\text { conservação de Q nos diferentes } \\
\text { exemplos. }\end{array}$ & $\begin{array}{l}\text { Forma: Docente considera as alegações dos estudantes } \\
\text { no processo de justificação e direciona o discurso para o } \\
\text { encerramento da atividade, alguns estudantes } \\
\text { acompanham seu raciocínio. Conteúdo: desenhos, gestos } \\
\text { e linguagem algébrica ajudam a justificar a modelização do } \\
\text { problema. Os alunos } 7 \text { e } 9 \text { aparentam compreender a } \\
\text { modelização feita pelo docente, porém, os alunos } 2 \text { e } 5 \\
\text { não compreendem, eles não vislumbram o processo e } \\
\text { focam no resultado que coincidentemente foi igual. }\end{array}$ \\
\hline $\begin{array}{l}4 \text { - Problemas } \\
\text { abertos sobre } \\
\text { colisões } \\
\text { inelásticas }\end{array}$ & $\begin{array}{c}\text { Classificação, } \\
\text { organização e definição } \\
\text { de variáveis são } \\
\text { importantes para a } \\
\text { construção da } \\
\text { explicação. Essas } \\
\text { etapas são } \\
\text { estabelecidas devido } \\
\text { às questões do } \\
\text { docente. }\end{array}$ & $\begin{array}{l}\text { Raciocínios abdutivos (uso dos } \\
\text { conceitos de massa e velocidade } \\
\text { separadamente) para justificar o } \\
\text { sentido de movimento, com a } \\
\text { cooperação entre a linguagem oral e a } \\
\text { esquemática. }\end{array}$ & $\begin{array}{l}\text { Forma: Perguntas do professor estimulam os alunos } \\
\text { justificarem suas alegações - apesar de precisarem serem } \\
\text { questionados, é provavel que eles tenham incorporado a } \\
\text { dependência (não simultânea) da massa e da velocidade } \\
\text { no fenômeno, não sentindo necessidade de justificá-lo. } \\
\text { Conteúdo: Abduções não relacionam massa e velocidade } \\
\text { através da conservação de Q, indicando não apropriação } \\
\text { dessa lei; A7 reproduz acriticamente o discurso do } \\
\text { docente sobre fazer a conta para determinar o sentido de } \\
\text { movimento após a colisão e ao refutar a ideia de A9; } \\
\text { alunos não justificam através da conservação de Q, mas a } \\
\text { partir dos conceitos intuitivos de massa e velocidade - } \\
\text { mesmo como docente destacando a necessidade de olhar } \\
\text { para os dois conceitos simultaneamente. Alunos não } \\
\text { vislumbramo papel da matemática na modelização e } \\
\text { solução é posta através da autoridade do professor (a fala } \\
\text { de A9 "eu odeio ela" ilustra bem isso). } \\
\end{array}$ \\
\hline $\begin{array}{c}5- \\
\text { Interpretação } \\
\text { dos resultados } \\
\text { matemáticos }\end{array}$ & $\begin{array}{c}\text { Professor classifica e } \\
\text { organiza as } \\
\text { informações, define as } \\
\text { variáveis relevantes ao } \\
\text { problema e constrói a } \\
\text { explicação. }\end{array}$ & $\begin{array}{c}\text { Linguagem algébrica, desenhos e } \\
\text { gestos es pecializaram os significados, } \\
\text { indicando a direção de movimento no } \\
\text { processo de elaboração e teste de } \\
\text { hipóteses. }\end{array}$ & $\begin{array}{l}\text { Forma: Alunos justificam quando o professor pergunta e } \\
\text { a discussão é direciona por ele para que se mantenha } \\
\text { atenção ao conceito de conservação de Q. Estudantes só } \\
\text { remetem a Q quando o conceito é indicado na lousa - } \\
\text { prevalescem justificativas nos conceitos intuitivos de } \\
\text { velocidade e massa. Conteúdo: As justificativas não se } \\
\text { valem da conservação de Q - a modelização do problema } \\
\text { se dá pelos conceitos intuitivos de massa e velocidade, } \\
\text { havendo um abismo entre fenômeno e representações. }\end{array}$ \\
\hline $\begin{array}{c}\text { 6-O problema } \\
\text { aberto dos } \\
\text { astronautas }\end{array}$ & $\begin{array}{l}\text { Estudantes classificam } \\
\text { e organizam as } \\
\text { informações e definem } \\
\text { as variáveis relevantes } \\
\text { para estabelecer a } \\
\text { explicação. }\end{array}$ & $\begin{array}{c}\text { Diferentes linguagens (incluindo a } \\
\text { algébrica) cooperam enquanto os } \\
\text { estudantes seriarm, classificame } \\
\text { organizam os dados do problema. } \\
\text { Além disso, elas ajudam a especializar a } \\
\text { explicação do resultado deduzido. }\end{array}$ & $\begin{array}{l}\text { Forma: Houveram justificativas implícitas (como a } \\
\text { ausência de atrito no espaço), outras que se valem da } \\
\text { autoridade de um exemplo (se baseiam no modelo dos } \\
\text { problemas resolvidos) e situações nas quais os } \\
\text { estudantes não conseguem justificar (A6 impõe sua visão } \\
\text { pelo tom de voze A2 e A6 não justificam as hipóteses } \\
\text { sobre o sentido de movimento). Conteúdo: Justificativas } \\
\text { foram baseadas em senso comum com estabelecimento de } \\
\text { estimativas absurdas (por exemplo A6 determina que a } \\
\text { massa do astronauta é vinte quilogramas), houve cópia } \\
\text { acrítica de um modelo de resolução (A2 entende que } \\
\text { modelar é copiar). A construção da explicação é mecânica } \\
\text { (fazer lição) e não há um 'retorno ao fenômeno' no final da } \\
\text { dedução. }\end{array}$ \\
\hline
\end{tabular}

Quadro 58: Argumentação campo-dependente nos seis episódios de ensino 
No primeiro episódio, os estudantes estavam mais 'próximos' do fenômeno e conseguiram relacionar os conceitos de massa e velocidade simultaneamente para discutir as colisões, com o uso especializado da linguagem algébrica, alcançando uma explicação coerente da situação. Eles se engajaram em um momento de fazer ciência (JIMÉNEZ-ALEIXANDRE et. al., 2000), que pode ser observado na ocasião em que os alunos do grupo chamam a atenção da colega, que queria guardar o material devido ao fim da aula estar próximo, porém, é evidente que houve uma dificuldade em associar o fenômeno e a representação matemática - o raciocínio abdutivo (adotar a regra de divisão como hipótese para explicar a repartição da quantidade de movimento nos corpos e que coincidentemente conduziu à valores numéricos iguais para o carro e caminhão), que persistiu no episódio 2, deveria ser discutido em detalhes no grande grupo.

Dessa forma, esse raciocínio abdutivo não seguiu o caminho que Rahman (2007) indica para essa prática: faltou o teste da hipótese explanatória (uso da regra de divisão), ou seja, não se verificou que essa inferência não era a melhor explicação e não houve uma revisão das concepções em um caminho plausível e racional. Assim, o posterior teste da ideia nova por meio da dedução (PIERCE, 2012; PEDEMONTE e REID, 2011; MISKULIN, 1999) ficou prejudicado, conduzindo os alunos a não refletirem sobre todo o processo, isto é, não houve na discussão com toda a turma:

1) explicitações de diferentes pontos de vista; 2) crítica mútua de posicionamentos; 3) tomadas de consciência dos alunos sobre suas próprias ideias e suas lacunas e inconsistências; 4) tensões e negociações entre os domínios de conhecimento cotidiano e de conhecimento científico; 5) explicitação, construção e reconstrução do pensamento dos alunos (VIEIRA e NASCIMENTO, 2009, p.83)

Isso indica que o tempo para debater as resoluções dos estudantes deve ser maior, para que eles consigam visualizar as colisões na representação matemática da conservação da quantidade de movimento. Evita-se assim prejudicar a justificação do uso da linguagem algébrica para a resolução das questões e dos problemas abertos, situação na qual destacamos que o discurso multimodal do professor deve ser construído com vistas a atingir esse objetivo. Posteriormente, o docente deve discutir como a linguagem fenomenológica se traduz na representação algébrica e vice-versa (LABURÚ et. al., 2011) - a introdução de uma atividade que fizesse os alunos escrever sobre essas relações talvez ajudasse na tomada de consciência sobre esses conhecimentos. O episódio 1 é marcante e ilustrativo, pois os alunos do grupo de 
análise compreendem qualitativamente que as quantidades de movimento devem ser iguais e manipulam os números de forma errônea para que o resultado seja o mesmo (dividindo a velocidade do carro pela do caminhão e depois a massa do caminhão pela do carro a fim de obter valores iguais). Como o raciocínio usado por esses estudantes não foi levado para toda a turma, dificultou-se o entendimento do modelo matemático e mesmo a noção qualitativa de conservação se tornou difusa ao longo dos episódios posteriores.

A dificuldade em modelizar matematicamente o problema fica explícita e persiste nos episódios 2 e 3, em que os estudantes não têm clareza sobre o que estão deduzindo (quantidade de movimento da bola ou do pé). Dessa forma, os alunos, apesar de apresentarem indícios de compreendem qualitativamente a conservação, não fecham o ciclo argumentativo e o professor acaba construindo a explicação.

Ao longo do episódio 4, as interpretações dos estudantes são focadas separadamente nos conceitos de massa e velocidade para justificar a direção de movimento. O docente tenta conduzir o diálogo de forma diretiva focando a explicação na conservação e sua relação com a matemática, situação que culmina no episódio 5 , no qual a linguagem algébrica, que vinha cooperando com o discurso mais os desenhos e gestos, passa a especializar os significados (direção de movimento e velocidade dos objetos após as colisões). Novamente os estudantes não vislumbram o papel da matemática na interpretação das situações.

Essa situação fica ainda mais evidente no episódio 6, no qual os alunos em pequenos grupos passam por todas etapas do ciclo argumentativo, mas a qualidade argumentativa novamente deixa a desejar - as linguagens cooperaram para estruturar o problema e especializaram a explicação do resultado deduzido 'mecanicamente', ou seja, os alunos do grupo de análise entendem que modelizar é copiar o modelo de resolução que se encontrava na lousa e fazem isso de forma acrítica, situação chamada de fazer lição por Jiménez-Aleixandre et. al. (2000). Observa-se esse fato nas estimativas absurdas realizadas e na não interpretação do resultado deduzido.

Face a essas reflexões, voltamos às questões de pesquisa e concluímos que o conhecimento matemático demandado pelos estudantes vale-se prioritariamente da linguagem algébrica no procedimento de realização de estimativas baseadas em conhecimento empírico e conhecimentos sistematizados para os valores das variáveis, no decorrer dos processos de seriação, classificação e organização de informações - que se encontram nas etapas de cuidado com os dados existentes e definição de variáveis 
relevantes ao problema do ciclo argumentativo. Eles evocam ainda em seus conhecimentos prévios algumas regras na forma de uma hipótese (abdução) para justificar o resultado, como a divisão para explicar a repartição da quantidade de movimento ou a equação da velocidade média.

Os processos dedutivos são realizados por meio da linguagem algébrica, porém, os estudantes não conseguem estabelecer uma explicação sólida sobre as situações propostas. Há um grande distanciamento entre os seus conhecimentos empíricos e o saber de como a matemática é usada para modelizar e explicar as situações físicas.

Em todas essas situações os esquemas e os gestos cooperam no estabelecimento de estimativas e na estruturação matemática do problema, que é apoiada por previsões, raciocínios lógicos e proporcionais e hipóteses. No final do processo, os alunos apenas repetem de forma acrítica um modelo de resolução, apesar das exposições e questionamentos do professor, nas discussões no grande grupo analisadas, que destacam a necessidade de se observar a construção matemática como uma linguagem e/ou um instrumento para observar e interpretar a realidade física de uma maneira mais abrangente (situações nas quais a linguagem matemática especializa os significados). Dessa maneira, a exposição e a problematização do docente se revelam insuficientes para encaminhar os alunos no processo de enculturação científica da interface entre física e matemática.

Vale ressaltar que as informações obtidas aqui, devem ser generalizadas com parcimônia, uma vez que se referem aos alunos que se manifestaram durante as aulas. Além disso, no grupo de análise, as duas participantes do sexo feminino nitidamente deixaram de participar devido à questões sexistas, ou melhor, devido ao preconceito de seus colegas - isso pode estar relacionado também ao que MacDonald e Kelly (2012) apontaram sobre as diferenças de gênero, na qual a competição de alegações pode ser desinteressante para uma parcela dos estudantes. Além do mais, nem todos os alunos desse grupo estiveram presentes em todas as aulas, prejudicando o acompanhamento dos conteúdos. E ainda, nem todos os estudantes sentem-se à vontade de se expressarem no grande grupo. Sendo assim, futuramente pretendemos acompanhar esses estudantes mais de perto, orientando e formando o professor colaborador para coletar a cada aula o material escrito de cada estudante e se necessário realizaremos entrevistas individuais com os participantes. 
Para que esse trabalho seja realizado, é importante também que se façam ajustes na sequência de ensino investigativa para evitar esse distanciamento entre fenômenos e representações - tal como planejar estratégias para discussão dos raciocínios abdutivos apresentados e introduzir atividades de modelização que amparem os alunos a perceberem as relações entre as colisões e suas matematizações. 


\section{Bibliografia}

ABERDEIN, A. The uses of argument in mathematics. Argumentation, v. 19, n.3, p.287-301, 2005.

Mathematics and argumentation. Foundations of Science, v. 14, n.1, p.1-8, 2009.

AMARAL, R. B. Argumentação matemática colaborativa em um ambiente online. Acta Scientiae, v.13, n.1, p.55-70, 2011.

BELLUCCO, A. Ensinando quantidade de movimento: como conciliar o tempo restrito com as atividades de ensino investigativas na sala de aula? Ciência em tela, v.5, n.1, 2012. Disponível em: http://www.cienciaemtela.nutes.ufrj.br/artigos/0112_carmo.pdf . Acesso em 08 de dez. de 14.

A linguagem matemática em uma aula experimental de física. 2006. 134f. Dissertação (Mestrado Interunidades Ensino de Ciências) - Instituto de Física, Faculdade de Educação, Universidade de São Paulo, São Paulo, 2006.

BELlUCCO, A.; CARVALHO, A.M.P. Múltiplas linguagens e a matemática no processo de argumentação em uma aula de física: análise dos dados de um laboratório aberto. Investigações em Ensino de Ciências (Online), v. 17, p.209-226, 2012. Disponível em: http://www.if.ufrgs.br/ienci/artigos/Artigo_ID290/v17_n1_a2012.pdf . Acesso em 08 de dez. de 14.

Construindo a linguagem gráfica em uma aula experimental de física. Ciência e Educação (UNESP), v. 15, p. 61-84, 2009a.

Construindo linguagem matemática em uma aula de física. In: Silvania Sousa do Nascimento; Christian Plantin. (eds.). Argumentação e Ensino de Ciências. 1. ed. Curitiba: Editora CRV, v. 1, p. 93-117, 2009b.

BONETTI, M; HOSOUME, Y.; PIETROCOLA, M. Cadernos de orientação do professor de Física - 1 ano - caderno 1. São Paulo: Secretaria de Educação do Estado de São Paulo, v.1, 55 p., 2010.

CAPECCHI, M. C. V. M. Aspectos da cultura científica em atividades de experimentação nas aulas de física. 2004. 264f. Tese (Doutorado em Educação) Faculdade de Educação, Universidade de São Paulo, São Paulo, 2004a.

Argumentação numa aula de Física. In: Carvalho, A. M. P. (ed.). Ensino de Ciências: unindo a pesquisa e a prática. São Paulo: Pioneira Thomson Learning, p. 5976, 2004b. 
CAPECCHI, M.C.V.M.; CARVALHO, A.M.P. Atividade de laboratório como instrumento para a abordagem de aspectos da cultura científica em sala de aula. ProPosições, v.17, n.1, p. 137-156, 2006.

CARVALHO, A.M.P. O ensino de ciências e a proposição de sequências de ensino investigativas. In: CARVALHO, A.M.P. (ed.) Ensino de ciências por investigação: condições para implementação em sala de aula. São Paulo: Cengage Learning, p.1-20, 2013.

Ensino e aprendizagem de Ciências: referenciais teóricos e dados empíricos das sequências de ensino investigativas- (SEI). In: Marcos Daniel Longhini. (ed.). O uno e o Diverso na Educação, 1 ed. Uberlândia: EDUFU, p. 253-266, 2011a.

- Uma metodologia de pesquisa para estudar os processos de ensino e aprendizagem em salas de aula. In: SANTOS, F. M. T.; GRECA, I. M. (eds.). A pesquisa em ensino de ciências no Brasil e suas metodologias. 2. ed. Ijuí: Unijuí, v. 1, p. 13-47, 2011b.

Física: uma proposta construtivista. São Paulo: EPU LTDA, 1989.

CARVAlho, A M. P, SANTOS, E. I., AZEVEDO, M. C. P. S., DATE, M. P. S., FUJII, S. R. S. E NASCIMENTO, V. B. Termodinâmica: um ensino por investigação. São Paulo, USP, 1999.

CHIZZOTI, A. Pesquisa qualitativa em ciências humanas e sociais. 4. ed. Petropolis, RJ: Vozes, 2011.

CORDOVIL, J. Is the major conceptual moment of orthodox quantum mechanics a momento f abduction? In: Pombo, O.; Gerner, A. (eds.). Abduction and the process of scientific discovery. Lisboa: Publidisa, p. 195-198, 2007.

DOVE, I.J. Towards a Theory of Mathematical Argument. Foundations of Science, n. 14, p.137-152, 2009.

DRIVER, R.; ASOKO, H.; LEACH, J.; MORTIMER, E. \& SCOTT, P. Construindo o conhecimento científico na sala de aula. Química na Nova Escola, n.9, maio, p.31-40, 1999.

EINSTEIN, A.; INFELD, L. A Evolução da Física. 1 ed. Rio de Janeiro: Zahar, 2008.

ERDURAN, S., Methodological Foundations in the Study of Argumentation in Science Classrooms, In: Jiménez-Aleixandre e Erduran, Argumentation in Science Education: Perspectives from Classroom-Based Research, Springer, Dordrecht, p.47-70, 2007.

ERICKSON, F. Qualitative research methods for science education. In: FRASER, B.J. \& TOBIN, K.G. (ed.). International Handbook of Science Education, v. 2, Kluwer Academic Publishes, p.1155-1173, 1998.

FEYNMAN R. P.; LEIGHTON, R. B.; SANDS, M. Lições de Física: edição definitiva, vol. I. Porto Alegre: Bookman, 2008. 
GIL PÉREZ, D.; MONTORO, I.F.; ALIS, J.C.; CACHAPUZ, A.; PRAIA, J. Para uma imagem não deformada do trabalho científico. Ciência \& Educação, v.7, n.2, p.125-153, 2001 .

GREF. Grupo de Reelaboração do Ensino de Física. Física 1: Mecânica, 7. ed., $1^{\mathrm{a}}$ reimpressão. São Paulo: EDUSP, 2002.

HARVARD PROJECT PHYSICS. Unidade 3 - O Triunfo da Mecânica - Texto e Manual de Experiências e Atividades - Fundação Calouste Gulbenkian, 1978.

INGLIS, M., MEJIA-RAMOS, J. P.,; SIMPSON, A. Modelling mathematical argumentation: The importance of qualification. Educational Studies in Mathematics, $\mathrm{n}$. 66, v.1, p.3-21, 2007.

JIMÉNEZ-ALEIXANDRE, M. P.; BUGALLO RODRÍGUEZ, A.; DUSCHL, R.A. "Doing the Lesson" or "Doing Science": argument in High School genetics. Science Education, n.84, n.6, p. 757-792, 2000.

JIMÉNEZ-ALEIXANDRE, M. P.; DÍAZ DE BUSTAMANTE, J., "Discurso de Aula y Argumentación en la clase de ciencias: cuestiones teóricas y metodológicas", Enseñanza de las Ciencias, v.21, n.3, p.359-370, 2003.

JIMÉNEZ-ALEIXANDRE, M.P. A argumentação sobre questões sócio-científicas: processos de construção e justificação do conhecimento na aula. In: Encontro Nacional de Pesquisa em Ensino de Ciências, n.5, 2005, Bauru. Atas... Bauru: ABRAPEC, 2005.

KARAM, R. A. S. Estruturação matemática do pensamento físico no ensino: uma ferramenta teórica para analisar abordagens didáticas. 2012. 275 f. Tese ( Doutorado em Educação) - Faculdade de Educação da Universidade de São Paulo, São Paulo, 2012.

KONSTANTINIDOU, K; CERVERÓ, J.M; CASTELLS, M. Argumentacion y concepciones cientificas de los estudiantes. Alambique: Didáctica de las Ciencias Experimentales, n.63, p. 26-38, 2010.

LABURÚ, C. E.; BARROS, M. A.; SILVA, O. H. Multimodos e múltiplas representações, aprendizagem significativa e subjetividade: três referenciais conciliáveis da educação científica. Ciência e Educação (UNESP. Impresso), v. 17, p.469-487, 2011.

LABURÚ, C. E.; SILVA, O. H. M. O Laboratório didático a partir da perspectiva da multimodalidade representacional. Ciência e Educação (UNESP. Impresso), v. 17, p.721-734, 2011.

LEMKE, J.L. Mathematics in the middle: measure, picture, gesture, sign, and word. In: Anderson, M., Saenz-Ludlow, A., Zellweger, S. e Cifarelli, V., (eds.). Educational Perspectives on Mathematics as Semiosis: From Thinking to Interpreting to Knowing. Ottawa: Legas Publishing, p.215-234, 2002.

Typological and topological meaning in diagnostic discourse. Discourse processes, v. 27, n. 2, p.173-85, 1999. 
Multiplying meaning: visual and verbal semiotics in scientific text. In: MARTIN, J.; VEEL, R. (eds.). Reading science. Londres: Routledge, p.87-113, 1998a.

Teaching all the languages of science: words, symbols, images and actions. In: CONFERENCE ON SCIENCE EDUCATION, 1998b. Disponível em: $<$ http://academic.brooklyn.cuny.edu/education/jlemke/sci-ed.htm>. Acesso em: 02 set. 2014.

Talking science: Language, learning and values. Norwood: Ablex Publishing Company, 1990.

. Aprender a Hablar Ciencia. Barcelona: Paidos, 1997.

MÁRQUEZ, C.; IZQUIERDO, M.; ESPINET, M. Comunicación multimodal en la clase de ciencias: el ciclo del agua. Enseñanza de las Ciencias, v. 21, n. 3, p.371-86, 2003.

MACDONALD, S.P.; KELLY, G.J. Beyond argumentation: sense-making discourse in the science classroom. In: Kline, M.S (ed.), Perspective on Scientific Argumentation. Bahrain: Springer, p. 265-282, 2012.

MACHADO, N.J. Matemática e realidade: análise dos pressupostos filosóficos que fundamentam o ensino de matemática. 7 ed. São Paulo: Cortez, 2009.

MISKULIN, R. G. S. Concepções teórico-metodológicas sobre a introdução e a utilização de computadores no processo ensino/aprendizagem da geometria. 1999. X f. Tese (Doutorado em Educação) - Faculdade de Educação, Universidade de Campinas, Campinas, Campinas, 1999.

MORTIMER, E. F.; SCOTT, P. H. . Atividade discursiva nas salas de aula de ciências: uma ferramenta sociocultural para analisar e planejar o ensino. Investigações em Ensino de Ciências (Online), v. 7, n.3, p.283-306, 2002. Disponível em: http://www.if.ufrgs.br/ienci/artigos/Artigo_ID94/v7_n3_a2002.pdf . Acesso em: 08 de dez. de 2014.

NASCIMENTO, S. S.; VIEIRA, R. D. A argumentação em sala de aula de física: limites e possibilidades de aplicação do padrão de Toulmin. In: Silvania Sousa do Nascimento, Christian Plantin. (Org.). Argumentação e ensino de Ciências. 1 ed. Curitiba: CRV, v. 1, p.17-37, 2009.

NEWTON, Isaac. Principia: Princípios Matemáticos de Filosofia Natural - Livro I. 2 ed. São Paulo: EDUSP, 2008.

PEDEMONTE, B.; REID, D. The role of abduction in proving processes. (English) Educacional Studies in Mathematics, v.76, n. 3, p.281-303, 2011.

PEIRCE, C.S. Semiótica. São Paulo: Perspectiva, 2012.

PEREIRA, A. G.; TERRAZZAN, E. A. A multimodalidade em textos de popularização científica: contribuições para o ensino de ciências pra crianças. Ciência e Educação (UNESP. Impresso), v. 17, p.489-503, 2011. 
PIETROCOLA, M. A matemática como estruturante do conhecimento físico. Caderno Brasileiro do Ensino de Física, v.17, n.1, p.93-114, 2002.

POHJOLA, P. What is abductive method? In: Pombo, O.; Gerner, A. (Eds.). Abduction and the process of scientific discovery. Lisboa: Publidisa, p.27-45, 2007.

PRETI, D. (org.) O discurso oral culto. São Paulo: Humanitas, 1997.

PSSC - PHYSICAL SCIENCE STUDY COMMITTEE; Guia do Professor: fundação brasileira para o desenvolvimento do ensino de ciências e centro de treinamento para professores de ciências. São Paulo: Edart - Livraria Editora Ltda, Vol. 1; Vol. 2; Vol. 3; Vol.4; 1968.

RAHMAN, S. Abduction, belief-revision and non-normality. In: Pombo, O.; Gerner, A. (Eds.). Abduction and the process of scientific discovery. Lisboa: Publidisa, p13-26, 2007.

REZENDE, W.S. Três grandes marcos do resgate retórico: Perelman, Toulmin e Meyer. CSOnline, Revista Eletrônica de Ciências Sociais, ano 4, n.10, p.96-130, 2010.

ROTH, W-M. Competent workplace mathematics: how signs become transparent in use. International Journal of Computers for Mathematical Learning, v. 8, n. 3, p.16189, 2003.

SAMPSON, V., CLARK, D. Assessment of argument in science education: a critical review of the literature. In: International Conference of the Learning Sciences, 7., 2006, Bloomington, NJ. Anais... Bloomington: International Society of the Learning Sciences, 2006, p.655-661.

SAMPSON, V.; ENDERIE, P.J.; WALKER, J.P. The development and validation of the Assessment of Scientific Argumentation in the Classroom (ASAC) observation protocol: a tool for evaluating how students participate in scientific argumentation. In: Kline, M.S (ed.), Perspective on Scientific Argumentation, p.235-264, 2012.

SANDOVAL, W. A.; MILLWOOD, K. A. What can argumentation tell us about epistemology? In: JIMÉNEZ-ALEIXANDRE, M. P.; ERDURAN, S. (eds.). Argumentation in Science Education: Perspectives from Classroom-Based Research. Berlin: Springer, p.71-88, 2007.

SASSERON, L.H. Alfabetização Científica no Ensino Fundamental: Estrutura e Indicadores deste processo em sala de aula. 2008. 265 f. Tese (Doutorado em Educação) - Faculdade de Educação, Universidade de São Paulo, 2008.

SASSERON, L. H.; CARVALHO, A. M. P. Uma análise dos referenciais teóricos sobre a estrutura do argumento para estudos de argumentação no ensino de ciências. Ensaio: Pesquisa em Educação em Ciências (Impresso), v. 13, p. 243-262, 2011a.

Construindo argumentação em sala de aula: a presença do ciclo argumentativo, os indicadores de Alfabetização Científica e o padrão de Toulmin. Ciência e Educação, v.17, n.1, p.97-114, 2011 b. 
SILVA, A.P.R.C.F. How can the example of Kepler's great scientific discovery illuminate the problematical nature of abduction? In: Pombo, O.; Gerner, A. (eds.). Abduction and the process of scientific discovery. Lisboa: Publidisa, p. 159-178, 2007.

SOUZA, V.F.M.; SASSERON, L. H. As interações discursivas no Ensino de Física: a promoção da discussão pelo professor e a alfabetização científica pelos alunos. Ciência e Educação (UNESP. Impresso), v. 18, p. 593-611, 2012a.

As perguntas em aulas investigativas de ciências: a construção teórica de categorias. Revista Brasileira de Pesquisa em Educação em Ciências, v. 12, p. 29-44, $2012 b$.

TOULMIM, S.E., Os Usos do Argumento, São Paulo: Martins Fontes, 2. ed., 2006.

VIEIRA, R. D.; NASCIMENTO, S. S. Contribuições e limites do padrão de Toulmin aplicado em situações a sala de aula de ciências. Revista Brasileira de Pesquisa em Educação em Ciências, v. 8, p.1-20, 2008.

- Uma proposta de critérios marcadores para a identificação de situações argumentativas em sala de aula de ciência. Caderno Brasileiro de Ensino de Física, v. 26, p.81-102, 2009.

YIN, R. K. Estudo de Caso: planejamentos e métodos. 4 ed. Porto Alegre: Bookman, 2010. 


\section{ANEXO I - TEXTO DE SISTEMATIZAÇÃO SOBRE CONSERVAÇÃO DA QUANTIDADE DE MOVIMENTO}

\section{O movimento se conserva}

A conservação da quantidade de movimento é um principio geral da Física que analisa o sistema físico por inteiro. A conservação significa que a variação do movimento em uma das partes do sistema necessariamente implica uma variação em outra parte do sistema.

É por isso que, quando estamos parados e passamos a andar para frente, algo vai começar a andar para trás; se fazemos uma curva a direita, algo deverá se mover para a esquerda; se jogamos algo para baixo, algo precisa ir para cima; enfim, os movimentos precisam se conservar, mas isso não parece corresponder ao que acontece na nossa vida, não é?

Estamos tão acostumados a fazer automaticamente as coisas, que deixamos de perceber o que é necessário para conseguir realizá-las. Por exemplo, ficar em pé é bastante complicado; as crianças demoram bastante para aprender a andar, mas, depois de alguns anos já fazem isso com muita facilidade. No entanto, basta aceitar o desafio de ficar em pé sobre o esqueite, os patins ou mesmo uma superfície lisa e cheia de óleo ou uma pista de patinação no gelo, para ver que não é tão fácil assim ficar em pé.

Também é patinando no gelo que reparamos que é bem difícil começar a andar para frente, e mais difícil ainda parar. Basta ver as pessoas caindo para todos os lados enquanto aprendem a patinar. Pense em que coisas e ações são necessárias para alterar o movimento das bolas, dos jogadores ou então dos carros nas competições. Você imagina como as bolas ou os atletas modificam suas trajetórias, indo de um lado para o outro das quadras, nos jogos e esportes competitivos?

As coisas que passam a se mover quando inicialmente estão paradas podem ser separadas em dois grupos. Em um deles é preciso ter uma "batida"; nela, a alteração pode ser pensada como a transferência da quantidade de movimento de algo que já estava em movimento para algo parado. O outro grupo pode ser pensado como a compensação da alteração do movimento de um corpo pela variação do movimento do outro, como ocorre nas interações por atrito, quando, por exemplo, um nadador joga agua para trás ou, quando em uma arrancada o carro "empurra" o chão para trás.

\section{Desafio}

Discuta com seus colegas e elabore dois exemplos (diferentes do texto) para cada um dos grupos das coisas que passam a se mover abordados no texto. Cada grupo deve entregar uma folha com sua resposta para o professor. 


\section{ANEXO II - EXEMPLO DA VALIDAÇÃO DA SEI}

Abaixo encontramos um exemplo de transcrição de uma das aulas da SEI, ministrada para uma turma de Física 1 da Universidade do Estado de Santa Catarina (aula 1 da sequência piloto, ministrada no dia 22/04/2013). A transcrição é apresentada em um quadro com uma coluna indicando o intervalo de tempo do extrato de aula apresentado; outra com a linguagem oral e as ações e os comentários sobre a fala, que aparecem entre parênteses duplos; uma coluna com a descrição das linguagens visual e escrita, que interagem com o modo oral; e uma última coluna subdividida em "ciclo argumentativo" e "argumentação". Quando há simultaneidade do uso entre duas ou mais linguagens, usamos negrito, sublinhado ou itálico nas duas últimas colunas.

\begin{tabular}{|c|c|c|c|}
\hline $\begin{array}{c}\text { Intervalo } \\
\text { de Tempo } \\
\text { (min:s) }\end{array}$ & $\begin{array}{l}\text { Linguagem Oral, Ações e } \\
\text { Comentários }\end{array}$ & Visual e Escrita & $\begin{array}{c}\text { Ciclo } \\
\text { Argumentativo }\end{array}$ \\
\hline \multirow[b]{3}{*}{$\begin{array}{c}00: 05: 10 \text { - } \\
00: 05: 30\end{array}$} & \multirow{3}{*}{$\begin{array}{l}\text { 2. A8: Beleza. } \\
\text { 3. A6: Assim... eu acho que essa } \\
\text { ideia de quanto menor a massa, } \\
\text { mais alto a gente tem que botar... } \\
\text { ((inaudível)). Vamos tentar } \\
\text { colocar aqui né? } \\
\text { 4. A?: (Vai baixo). } \\
\text { 5. A5: Faz a mesma com essa } \\
\text { daqui. }\end{array}$} & \multirow{3}{*}{$\begin{array}{l}\text { Puxa a bolinha } \\
\text { menor na } \\
\text { horizontal em } \\
\text { relação ao ponto } \\
\text { de apoio do } \\
\text { pêndulo, aponta } \\
\text { e em seguida } \\
\text { solta. } \\
\text { Apontando para a } \\
\text { bolinha maior do } \\
\text { outro lado. }\end{array}$} & $\begin{array}{l}\text { - Cuidado com } \\
\text { os dados. }\end{array}$ \\
\hline & & & Argumentação \\
\hline & & & $\begin{array}{l}\text { - Raciocínio } \\
\text { proporcional. } \\
\text { - Seriação. } \\
\text { - Hipóteses }\end{array}$ \\
\hline $\begin{array}{c}\text { Intervalo } \\
\text { de Tempo } \\
\text { (min:s) }\end{array}$ & $\begin{array}{c}\text { Linguagem Oral, Ações e } \\
\text { Comentários }\end{array}$ & Visual e Escrita & $\begin{array}{c}\text { Ciclo } \\
\text { Argumentativo }\end{array}$ \\
\hline \multirow[t]{3}{*}{$\begin{array}{l}00: 05: 30- \\
00: 05: 58\end{array}$} & \multirow{3}{*}{$\begin{array}{l}\text { 6. A?: Beleza. } \\
((\text { A6 faz o teste sugerido e a } \\
\text { bolinha faz um looping)). } \\
\text { 7. Todos: ((risos)). } \\
\text { 8. A8: Opa ((risos)). } \\
\text { 9. A7: Acho que a massa tem } \\
\text { alguma coisa a ver. } \\
\text { 10. A8 e A6: ((juntos } \\
\text { concordando)) Acho que a massa } \\
\text { tem alguma coisa a ver. ((Todos } \\
\text { fazem expressão de que } \\
\text { concordam e riem)). }\end{array}$} & \multirow[t]{3}{*}{ Pêndulo. } & $\begin{array}{l}\text { - Definição de } \\
\text { variáveis. }\end{array}$ \\
\hline & & & Argumentação \\
\hline & & & $\begin{array}{l}\text { - Abdução. } \\
\text { - Justificativa. } \\
\text { - Garantia. }\end{array}$ \\
\hline $\begin{array}{c}\text { Intervalo } \\
\text { de Tempo } \\
\text { (min:s) } \\
\end{array}$ & $\begin{array}{c}\text { Linguagem Oral, Ações e } \\
\text { Comentários }\end{array}$ & Visual e Escrita & $\begin{array}{c}\text { Ciclo } \\
\text { Argumentativo }\end{array}$ \\
\hline
\end{tabular}




\begin{tabular}{|c|c|c|c|}
\hline \multirow[t]{3}{*}{$\begin{array}{c}00: 05: 58 \text { - } \\
00: 06: 24\end{array}$} & \multirow{3}{*}{$\begin{array}{l}\text { 11. A6: ((Faz uma pergunta para } \\
\text { A5, aparentemente solicitando que } \\
\text { ele explique o que entendeu)). } \\
\text { 12. A5: Dá para ver que a } \\
\text { velocidade dessa daqui... vai ser } \\
\text { bem maior do que a dessa daqui. A } \\
\text { hora que você a soltou ((a bolinha } \\
\text { grande)), essa daqui saiu bem mais } \\
\text { rápido. } \\
\text { 13. A6: A velocidade... ((para e } \\
\text { fica pensativo)). } \\
\text { 14. A5: É... a velocidade é bem } \\
\text { maior... } \\
\text { 15. A4: É... verdade... ((A3 faz } \\
\text { gesto afirmativo com a cabeça)). } \\
\text { 16. A8: É isso aí. } \\
\text { 17. A6: Tá. Tu tá dizendo que a } \\
\text { velocidade ré é relativa } \\
\text { ((inaudível))... é relativa à massa } \\
\text { dela ((colegas fazem gesto } \\
\text { afirmativo)). } \\
\text { 18. A5: ((Inaudível)). }\end{array}$} & \multirow{3}{*}{ 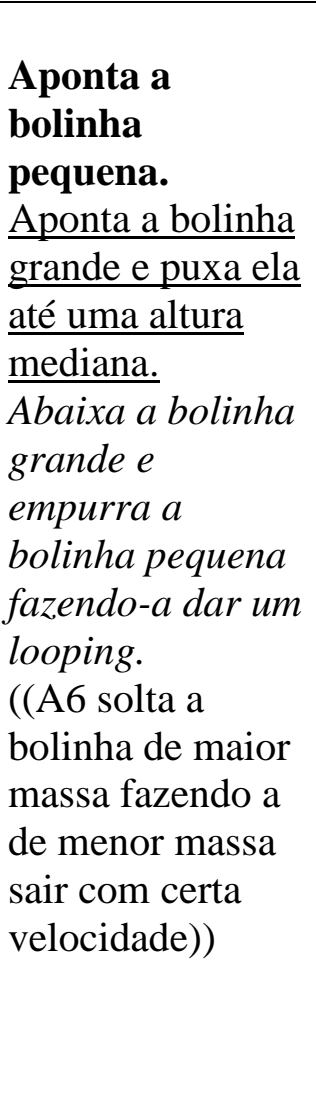 } & $\begin{array}{l}\text { - Cuidado com } \\
\text { os dados. } \\
\text { - Definição de } \\
\text { variáveis. } \\
\text { - Abdução. }\end{array}$ \\
\hline & & & Argumentação \\
\hline & & & $\begin{array}{l}\text { Classificação e } \\
\text { organização. } \\
\text { - Garantia. } \\
\text { - Dados e } \\
\text { conclusões. } \\
\text { - Qualificador. }\end{array}$ \\
\hline $\begin{array}{c}\text { Intervalo } \\
\text { de Tempo } \\
\text { (min:s) }\end{array}$ & $\begin{array}{c}\text { Linguagem Oral, Ações e } \\
\text { Comentários }\end{array}$ & Visual e Escrita & $\begin{array}{c}\text { Ciclo } \\
\text { Argumentativo }\end{array}$ \\
\hline \multirow[t]{3}{*}{$\begin{array}{l}00: 06: 24- \\
00: 06: 58\end{array}$} & \multirow{3}{*}{$\begin{array}{l}\text { 19. A6: Tá, só que essa aqui... ela } \\
\text { passa uma energia cinética, ela } \\
\text { passa para as outras. Porque aqui } \\
\text { ela está com energia potencial. A } \\
\text { energia deve se conservar. } \\
\text { 20. A8: Não joga tão alto. } \\
\text { 21. A6: É. O que que você acha? } \\
\text { ((perguntando para A8)). } \\
\text { 22. A8: Hum. ((é interrompida por } \\
\text { uma fala da professora direcionada } \\
\text { a outro grupo e todos ficam } \\
\text { pensativos)). } \\
\text { 23. P: Vocês podem pensar, se } \\
\text { todas as esferas fossem iguais. } \\
\text { Tivessem a mesma massa. O que } \\
\text { iria acontecer? Então... todas essas } \\
\text { hipóteses vocês podem provar... } \\
\text { ((Continua a falar com outro grupo } \\
\text { enquanto esse grupo começa a } \\
\text { fazer hipóteses sobre as massas)). }\end{array}$} & \multirow{3}{*}{$\begin{array}{l}\text { Bolinha maior. } \\
\underline{\text { Arrasta a bolinha }} \\
\frac{\text { maior até a }}{\text { horizontal em }} \\
\underline{\text { relação ao ponto }} \\
\underline{\text { de apoio e solta. }}\end{array}$} & $\begin{array}{l}\text { - Explicação. } \\
\text { - Definição de } \\
\text { variáveis. }\end{array}$ \\
\hline & & & Argumentação \\
\hline & & & $\begin{array}{l}\text { - Abdução. } \\
\text { - Classificação } \\
\text { e Organização. } \\
\text { - Justificação. } \\
\text { - Garantia. } \\
\text { - Apoio. } \\
\text { - Qualificador. }\end{array}$ \\
\hline $\begin{array}{c}\text { Intervalo } \\
\text { de Tempo } \\
\text { (min:s) }\end{array}$ & $\begin{array}{c}\text { Linguagem Oral, Ações e } \\
\text { Comentários }\end{array}$ & Visual e Escrita & $\begin{array}{c}\text { Ciclo } \\
\text { Argumentativo }\end{array}$ \\
\hline
\end{tabular}




\begin{tabular}{|c|c|c|c|}
\hline \multirow[t]{3}{*}{$\begin{array}{c}00: 07: 00- \\
00: 07: 53\end{array}$} & \multirow{3}{*}{$\begin{array}{l}\text { 24. A5: Essas duas são iguais? } \\
\text { (Acho que essas duas são iguais). } \\
\text { 25. A6: ((voltando-se para o } \\
\text { pesquisador)) Essa duas são } \\
\text { iguais... a massa delas? } \\
\text { Pesquisador: São... deixa eu tirar } \\
\text { isso ((referindo-se a gravação. } \\
\text { Alunos riem)). } \\
\text { ((A5 tira a esfera menor)). } \\
\text { 26. A8: Mas daí não vai ter... } \\
\text { 27. A6: É... vai na mesma altura. } \\
\text { 28. A5: Vai na mesma altura. } \\
\text { 29. A8: Muito divertido ta (hein)... } \\
\text { a gente pode tentar calcular isso } \\
\text { tipo... literalmente. } \\
\text { 30. A7: O que?... tem a ver com a } \\
\text { massa. } \\
\text { 31. A8: Cara é óbvio que tem a ver } \\
\text { com a massa. } \\
\text { 32. A6: Tu queres mexer aí? ((para } \\
\text { A7 e A8)). } \\
\text { 33. A8: .... não... } \\
\text { ((alunos pensam e escrevem)) }\end{array}$} & \multirow[t]{2}{*}{$\begin{array}{l}\text { Apontando para } \\
\text { as duas esferas } \\
\text { maiores. }\end{array}$} & $\begin{array}{l}\text { - Cuidado com } \\
\text { os dados. } \\
\text { - Definição de } \\
\text { variáveis. }\end{array}$ \\
\hline & & & Argumentação \\
\hline & & $\begin{array}{l}\frac{\text { A6 faz a colisão }}{\text { entre os dois }} \\
\underline{\text { pêndulos }} \\
\underline{\text { restantes. }}\end{array}$ & $\begin{array}{l}\text { - Seriação. } \\
\text { - Hipóteses. } \\
\text {-Classificação e } \\
\text { Organização. } \\
\text { - Justificativa. } \\
\text { - Dado. } \\
\text { - Conclusão. } \\
\text { - Garantia. }\end{array}$ \\
\hline $\begin{array}{r}\text { Intervalo } \\
\text { de Tempo } \\
\text { (min:s) }\end{array}$ & $\begin{array}{c}\text { Linguagem Oral, Ações e } \\
\text { Comentários }\end{array}$ & Visual e Escrita & $\begin{array}{c}\text { Ciclo } \\
\text { Argumentativo }\end{array}$ \\
\hline \multirow[t]{3}{*}{$\begin{array}{c}00: 07: 53- \\
00: 09: 15\end{array}$} & \multirow{3}{*}{$\begin{array}{l}\text { ((Alunos fazem anotações e A3 faz } \\
\text { mais uma colisão)). } \\
\text { 34. A1: O problema é que ele... } \\
\text { não passa toda a energia. Por que } \\
\text { ele bate, mas também continua } \\
\text { indo... fora quando ele não bate } \\
\text { meio de lado ele acaba indo de } \\
\text { lado assim. } \\
\text { 35. A8: Eu acho que o brinquedo } \\
\text { nos trolou então... não pode ter a } \\
\text { ver com a massa... por que se vai } \\
\text { passar energia potencial... levanta a } \\
\text { bolinha maior. } \\
\text { 36. A1: Tem um pouco a ver com a } \\
\text { massa sim, porque... } \\
\text { interrompido por A8)). } \\
\text { 37. A8: Tá. Agora bate... pode } \\
\text { parar... levanta a menor. } \\
38 . \text { A6: Qual? } \\
\text { 39. A8: A menor... Tecnicamente } \\
\text { tem... mas tipo... } \\
\text { 40. A1: É porque... tipo a energia } \\
\text { da pequena pode ser a mesma, mas } \\
\text { é necessário/tipo uma força menor }\end{array}$} & \multirow{2}{*}{$\begin{array}{l}\text { Mão se } \\
\text { afastando do } \\
\text { corpo, seguido } \\
\text { de gesto com } \\
\text { uma mão } \\
\text { parcialmente } \\
\text { sobreposta a } \\
\text { outra e se } \\
\text { afastando de } \\
\text { novo. } \\
\text { A6 levanta a } \\
\text { bolinha maior. }\end{array}$} & $\begin{array}{l}\text { - Explicação. } \\
\text { - Definição de } \\
\text { variáveis. }\end{array}$ \\
\hline & & & Argumentação \\
\hline & & $\begin{array}{l}\text { A6 solta a } \\
\text { bolinha maior. } \\
\text { A6 levanta e } \\
\text { solta a bolinha } \\
\text { menor. }\end{array}$ & $\begin{array}{l}\text { - Abdução. } \\
\text { - Hipóteses. } \\
\text { - Justificativa. } \\
\text { - Garantia. } \\
\text { - Refutação. }\end{array}$ \\
\hline
\end{tabular}




\begin{tabular}{|c|c|c|c|}
\hline & $\begin{array}{l}\text { para mexer ela mais rápido do que } \\
\text { para a maior... então ela vai passar } \\
\text { a energia... } \\
\text { 41. A2: Então... a energia... da } \\
\text { pequena... é menor porque... pela } \\
\text { energia potencial gravitacional que } \\
\text { todas tem depende da massa... e a } \\
\text { energia potencial da pequena } \\
\text { depende da massa. ///A1: Sim... é... } \\
\text { a energia potencial da pequena. } \\
\text { 42. A8: Tá e quando vai transferir } \\
\text { a energia... a energia cinética... } \\
\text { também vai depender da massa /// } \\
\text { 43. A1: Sim ((junto com 'vai } \\
\text { depender da massa')). }\end{array}$ & & \\
\hline $\begin{array}{c}\text { Intervalo } \\
\text { de Tempo } \\
\text { (min:s) } \\
\end{array}$ & $\begin{array}{c}\text { Linguagem Oral, Ações e } \\
\text { Comentários }\end{array}$ & Visual e Escrita & $\begin{array}{c}\text { Ciclo } \\
\text { Argumentativo }\end{array}$ \\
\hline \multirow[t]{3}{*}{$\begin{array}{l}00: 09: 15- \\
00: 09: 48\end{array}$} & \multirow{3}{*}{$\begin{array}{l}\text { 44. A5: Depende da massa. ((todos } \\
\text { riem)). } \\
\text { 45. A8: Tá, mas... NÃO, não é } \\
\text { isso... ((enquanto os colegas riem e } \\
\text { fala algo inaudível)). } \\
\text { 46. A5: Depende da massa. } \\
\text { 47. A?: Quantifica isso ai. } \\
\text { 48. A6: É porque a fórmula da } \\
\text { energia cinética é massa vezes } \\
\text { velocidade ao quadrado sobre... } \\
\text { 49. A3: Dois... } \\
\text { 50. A6: Dois. } \\
\text { 51. A4: Tá, como elevar duas } \\
\text { bolinhas sempre à mesma altura? } \\
\text { ((lendo à questão no guia)). } \\
\text { 52. A6: é duas bolas de mesma } \\
\text { massa... vão ser elevadas à mesma } \\
\text { altura no caso do pêndulo. Vamos } \\
\text { de novo. ((começam a fazer os } \\
\text { testes com duas bolinhas de mesma } \\
\text { massa)) }\end{array}$} & \multirow[t]{3}{*}{$\begin{array}{l}\text { Pêndulos são } \\
\text { usados como } \\
\text { referência para a } \\
\text { discussão em } \\
\text { todo esse trecho. }\end{array}$} & $\begin{array}{l}\text { - Explicação. } \\
\text { - Definição das } \\
\text { variáveis. }\end{array}$ \\
\hline & & & Argumentação \\
\hline & & & $\begin{array}{l}\text { - Abdução. } \\
\text { - Justificativa. } \\
\text { - Classificação } \\
\text { e Organização. } \\
\text { - Dado. } \\
\text { - Garantia. } \\
\text { - Conclusão. }\end{array}$ \\
\hline $\begin{array}{c}\text { Intervalo } \\
\text { de Tempo } \\
\text { (min:s) }\end{array}$ & $\begin{array}{c}\text { Linguagem Oral, Ações e } \\
\text { Comentários }\end{array}$ & Visual e Escrita & $\begin{array}{c}\text { Ciclo } \\
\text { Argumentativo }\end{array}$ \\
\hline
\end{tabular}




\begin{tabular}{|c|c|c|c|}
\hline \multirow[t]{3}{*}{$\begin{array}{c}00: 09: 48- \\
00: 10: 15\end{array}$} & \multirow{3}{*}{$\begin{array}{l}\text { 53. A4: Tipo ele sobe } \\
\text { extremamente rápido. } \\
\text { 54. A6: ((inaudível)) tem que } \\
\text { tentar de novo. } \\
\text { 55. A4: ((inaudível)) ... uma régua. } \\
\text { 56. A7: Mas ele não vai porque } \\
\text { tem muita coisa aí. } \\
\text { 57. A1: Tem a força de resistência } \\
\text { do ar envolvida aí também. } \\
\text { 58. A6: ((ao colocar a régua na } \\
\text { horizontal)) Isso isso. } \\
\text { 59. A4: Apoia aqui. } \\
\text { 60. A8: ((inaudível ao mesmo } \\
\text { tempo que A6)) ... fazendo esse } \\
\text { experimento fica fácil. } \\
\text { 61. A6: segura aí para mim. } \\
\text { 62. A5: Olha as ideias... }\end{array}$} & \multirow{3}{*}{$\begin{array}{l}\text { A6 deixa a mão } \\
\text { na horizontal } \\
\text { como parâmetro } \\
\text { para ter uma } \\
\text { ideia da altura. } \\
\text { Faz uma nova } \\
\text { colisão. } \\
\text { A4 passa uma } \\
\text { régua para A6 } \\
\text { que a cola na } \\
\text { horizontal, na } \\
\text { mesma altura das } \\
\text { bolinhas. } \\
\text { Apontando para } \\
\text { um ponto no } \\
\text { suporte do } \\
\text { pêndulo que fica } \\
\text { a uns } 5 \text { cm acima } \\
\text { das bolinhas. } \\
\text { A3 segura a } \\
\text { régua no ponto } \\
\text { escolhido pelo } \\
\text { grupo. } \\
\text { A6 segura uma } \\
\text { bolinha na } \\
\text { mesma altura da } \\
\text { régua. }\end{array}$} & $\begin{array}{l}\text { - Definição de } \\
\text { variáveis. } \\
\text { - Explicação. }\end{array}$ \\
\hline & & & Argumentação \\
\hline & & & $\begin{array}{l}\text { - Hipóteses. } \\
\text { - Classificação } \\
\text { e Organização. } \\
\text { - Abdução. } \\
\text { - Justificativa. } \\
\text { - Garantia. }\end{array}$ \\
\hline $\begin{array}{c}\text { Intervalo } \\
\text { de Tempo } \\
\text { (min:s) }\end{array}$ & $\begin{array}{c}\text { Linguagem Oral, Ações e } \\
\text { Comentários }\end{array}$ & Visual e Escrita & $\begin{array}{c}\text { Ciclo } \\
\text { Argumentativo }\end{array}$ \\
\hline \multirow[t]{3}{*}{$\begin{array}{c}00: 10: 17- \\
00: 11: 12\end{array}$} & \multirow{3}{*}{$\begin{array}{l}\text { 64. A?: Vai. } \\
\text { 65. A6: Foi... vamos refazer a } \\
\text { medida agora... será que a massa } \\
\text { dessa metade... é metade dessa. } \\
\text { 66. A5: tem como (concluir). } \\
\text { 67. A8: só se a gente fazer o } \\
\text { cálculo. } \\
\text { 68. A6: se a gente dobrar a altura... } \\
\text { se a gente tivesse metade da } \\
\text { massa... a gente dobrasse a } \\
\text { altura... ((inaudível))... altura... } \\
\text { essa altura certinha. } \\
\text { 69. A5: Não... } \\
\text { 70. A1: o problema é que a } \\
\text { pequena... ela bate... ela num vai } \\
\text { contin/ num passa direito numa } \\
\text { reta/ ela paga devia } \\
\text { ((A6 faz nova colisão entre a } \\
\text { bolinha pequena e a grande)) }\end{array}$} & \multirow{3}{*}{ 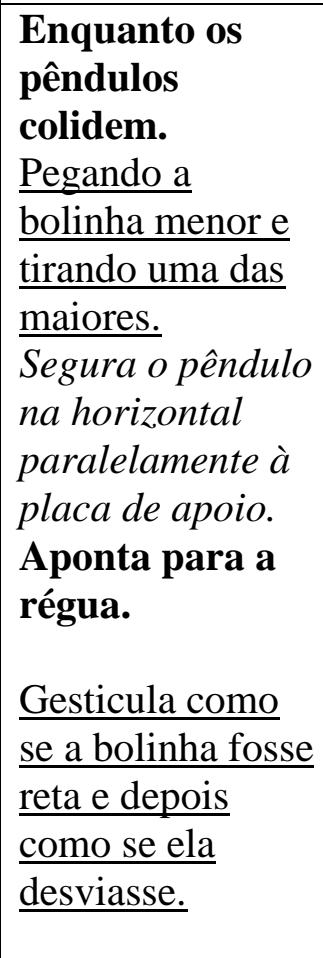 } & $\begin{array}{l}\text { - Cuidado com } \\
\text { os dados. } \\
\text { - Definição de } \\
\text { variáveis. }\end{array}$ \\
\hline & & & Argumentação \\
\hline & & & $\begin{array}{l}\text { - Hipóteses. } \\
\text { - Previsão. } \\
\text { - Raciocínio } \\
\text { proporcional. } \\
\text { - Refutação. }\end{array}$ \\
\hline
\end{tabular}




\begin{tabular}{|c|c|c|c|}
\hline & $\begin{array}{l}\text { 71. A6: ((inaudível)) É que ela } \\
\text { pega muito pouca velocidade. O } \\
\text { que tu acha? ((para A9)). } \\
\text { 72. A9: ((inaudível)) }\end{array}$ & & \\
\hline $\begin{array}{l}\text { Intervalo } \\
\text { de Tempo } \\
\text { (min:s) }\end{array}$ & $\begin{array}{c}\text { Linguagem Oral, Ações e } \\
\text { Comentários }\end{array}$ & Visual e Escrita & $\begin{array}{c}\text { Ciclo } \\
\text { Argumentativo }\end{array}$ \\
\hline \multirow[t]{3}{*}{$\begin{array}{c}00: 11: 12- \\
00: 13: 41\end{array}$} & \multirow{3}{*}{$\begin{array}{l}\text { 73. A5: Essa aqui tem que ser... } \\
\text { mais que o dobro da altura pra... } \\
\text { 74. A6: Tá... mas a gente tem que } \\
\text { relacionar com o que isso daí? A } \\
\text { gente ((inaudível)) } \\
\text { 75. A1: ((inaudível))... interferir ... } \\
\text { a energia passa direto ((inaudível)). } \\
\text { 76. A2: ((inaudível)). } \\
\text { 77. A5: Tem que ser retinho } \\
\text { também. } \\
\text { ((Discussão inaudível - A6 acerta } \\
\text { as distâncias entre as bolinhas nos } \\
\text { pêndulos e faz uma colisão } \\
\text { soltando a bolinha maior)) } \\
\text { 78. A5: E se colocar essa daqui? } \\
\text { ((A6 faz mais uma colisão soltando } \\
\text { a bolinha pequena)). } \\
\text { 79. A5: Melhorou. } \\
\text { 80. A6: Engraçado... } \\
\text { melhorou bem. } \\
\text { ((Discussão inaudível. A6 faz nova } \\
\text { colisão, soltando a bolinha } \\
\text { pequena)) }\end{array}$} & \multirow{2}{*}{$\begin{array}{l}\text { Arrasta a } \\
\text { bolinha pequena } \\
\text { até a altura do } \\
\text { ponto de apoio. }\end{array}$} & $\begin{array}{l}\text { - Definição de } \\
\text { variáveis. }\end{array}$ \\
\hline & & & Argumentação \\
\hline & & $\begin{array}{l}\text { Aponta para a } \\
\text { ponto de apoio } \\
\text { da linha do } \\
\text { pêndulo e ajusta } \\
\text { a posição do } \\
\text { mesmo. }\end{array}$ & $\begin{array}{l}\text { - Seriação. } \\
\text { - Classificação } \\
\text { e Organização. } \\
\text { - Raciocínio } \\
\text { Proporcional. } \\
\text { - Hipóteses. } \\
\text { - Conclusão. }\end{array}$ \\
\hline
\end{tabular}




\title{
ANEXO III - MODELO DAS AUTORIZAÇÕES DE PESQUISA
}

\author{
Modelo para a Universidade
}

\section{TERMO DE CONSENTIMENTO LIVRE E ESCLARECIDO}

Você está sendo convidado(a) a participar de uma pesquisa como voluntário(a). Após receber os esclarecimentos e as informações a seguir, no caso de aceitar fazer parte do estudo, assine ao final deste documento (duas páginas), que está em duas vias. Uma delas é sua, e a outra é do pesquisador. Em caso de recusa, você não será penalizado(a) de forma alguma. Em caso de dúvida, você poderá esclarecê-las com os pesquisadores relacionados abaixo.

\section{INFORMAÇÕES SOBRE A PESQUISA}

Título do Projeto: Argumentação matemática em aulas investigativas de física

Pesquisador Responsável e Participante: Alex Bellucco do Carmo - Doutorando do Programa de Pós-Graduação Educação da Faculdade de Educação da USP. Contato: alexbellucco@gmail.com

\section{Descrição da pesquisa}

Com essa pesquisa, temos como objetivo geral estudar a aprendizagem de física envolvendo a argumentação matemática, durante atividades de investigação científica. Objetivo que se desdobra nas seguintes partes específicas: (a) relacionar teoricamente aspectos da Teoria da Argumentação com os estudos sobre linguagens no ensino de ciências; (b) preparar e implementar, em sala de aula, um conjunto de atividades didáticas de caráter investigativo visando argumentação e a aprendizagem das linguagens científicas, em especial a matemática; (c) analisar o processo de desenvolvimento da argumentação matemática dos acadêmicos em aulas de física de terceiro grau, nas quais ocorrerão intervenções didáticas baseadas no ensino investigativo. Todas as etapas da pesquisa acontecerão em dias letivos, não sendo necessários deslocamentos para a universidade em horários extraclasse. Os acadêmicos participarão da pesquisa da seguinte forma:

1. Se envolvendo nas atividades didáticas preparadas de acordo com a perspectiva do ensino por investigação, gerando documentos escritos que podem ser usados como fonte de dados para a pesquisa. Estas atividades serão desenvolvidas pelo professor responsável pela disciplina e serão acompanhadas pelo pesquisador participante (Alex Bellucco do Carmo). Portanto, serão feitas observações diretas e videogravação de aulas.

2. Respondendo à entrevista individual que ocorrerá no ambiente acadêmico sendo coordenadas pelo pesquisador participante. As entrevistas abordarão aspectos gerais o papel da matemática na física e, principalmente, esclarecerão dubiedades em relação às informações obtidas com os demais instrumentos de coleta.

O professor da disciplina participará da pesquisa coordenando todas as sessões de implementação das atividades didáticas que serão acompanhadas e analisadas.

IMPORTANTE: Em nenhum momento serão divulgados os nomes dos participantes e todo o material coletado será utilizado apenas com o propósito da pesquisa. Nenhum dos participantes terá gastos financeiros com a pesquisa. Por se tratar de uma pesquisa acadêmica sem fins lucrativos não haverá qualquer compensação financeira pelo uso deste material registrado.

Essa pesquisa não oferece nenhum risco de ordem física aos participantes, entretanto, pelo fato de envolver gravações em áudio e vídeo, podem gerar desconfortos associados a esses meios. Por esse motivo, será garantida a liberdade do participante, seja professor ou acadêmico, de se recusar a participar ou de retirar seu consentimento em qualquer fase da pesquisa sem penalização ou prejuízo algum. Após análise, a essência do material constituirá a parte empírica da tese de doutorado do pesquisador Alex Bellucco do Carmo, que se compromete trazer nesse trabalho contribuições concretas em relação ao ensino e a aprendizagem da Física, tanto para a educação básica quanto para o ensino superior. O encerramento da pesquisa se dará após avaliação final do material coletado que será arquivado para possíveis análises futuras e/ou para fins didáticos. 
Caso necessitarem de maiores explicações, os pesquisadores estarão à disposição para esclarecer as dúvidas, pelo correio eletrônico ou pessoalmente.

Prof. Alex Bellucco do Carmo

Pesquisador Responsável

\section{CONSENTIMENTO DA PARTICIPAÇÃO (assinado pelo(a) estudante)}

$E \boldsymbol{E}$, RG/ CPF

abaixo assinado, concordo em participar da pesquisa Argumentação matemática em aulas investigativas de física. Fui devidamente informado(a) e esclarecido(a) pela pesquisador Alex Bellucco do Carmo e por meio desse termo sobre a pesquisa, os procedimentos nela envolvidos, assim como os possíveis riscos e benefícios decorrentes de minha participação. Foi-me garantido que posso retirar meu consentimento a qualquer momento, sem que isto me leve a qualquer penalidade ou prejuízo.

Joinville, de de 2013.

Assinatura

\section{Modelo para a Escola de Ensino Básico}

\section{TERMO DE CONSENTIMENTO LIVRE E ESCLARECIDO}

Você está sendo convidado(a) a participar de uma pesquisa como voluntário(a). Após receber os esclarecimentos e as informações a seguir, no caso de aceitar fazer parte do estudo, assine ao final deste documento (duas páginas), que está em duas vias. Uma delas é sua, e a outra dos pesquisadores. Em caso de recusa, você não será penalizado(a) de forma alguma. Em caso de dúvida, você poderá esclarecê-las com os pesquisadores relacionados abaixo.

\section{INFORMAÇÕES SOBRE A PESQUISA}

Título do Projeto: Argumentação matemática em aulas investigativas de física Pesquisador Responsável e Participante: Alex Bellucco do Carmo - Doutorando do Programa de Pós-Graduação Educação da Faculdade de Educação da USP. Contato: alexbellucco@gmail.com

\section{Descrição da pesquisa}

Com essa pesquisa, temos como objetivo geral estudar a aprendizagem de física envolvendo a argumentação matemática, durante atividades de investigação científica. Objetivo que se desdobra nas seguintes partes específicas: (a) relacionar teoricamente aspectos da Teoria da Argumentação com os estudos sobre linguagens no ensino de ciências; (b) preparar e implementar, em sala de aula, um conjunto de atividades didáticas de caráter investigativo visando argumentação e a aprendizagem das linguagens científicas, em especial a matemática; (c) analisar o processo de desenvolvimento da argumentação matemática dos alunos em aulas de física do ensino médio, nas quais ocorrerão intervenções didáticas baseadas no ensino investigativo. Todas as etapas da pesquisa acontecerão em dias letivos, não sendo necessários 
deslocamentos para a escola em horários extraclasse. Os alunos participarão da pesquisa da seguinte forma:

3. Se envolvendo nas atividades didáticas preparadas de acordo com a perspectiva do ensino por investigação, gerando documentos escritos que podem ser usados como fonte de dados para a pesquisa. Estas atividades serão desenvolvidas pelo professor responsável pela disciplina e serão acompanhadas pelo pesquisador participante (Alex Bellucco do Carmo). Portanto, serão feitas observações diretas e videogravação de aulas.

4. Respondendo à entrevista individual que ocorrerá no ambiente escolar sendo coordenadas pelo pesquisador participante. As entrevistas abordarão aspectos gerais o papel da matemática na física e, principalmente, esclarecerão dubiedades em relação às informações obtidas com os demais instrumentos de coleta.

O professor da disciplina de física participará da pesquisa coordenando todas as sessões de implementação das atividades didáticas que serão acompanhadas e analisadas.

IMPORTANTE: Em nenhum momento serão divulgados os nomes dos participantes e todo o material coletado será utilizado apenas com o propósito da pesquisa. No caso dos alunos que tem idade inferior a 18 anos, os pais ou responsáveis deverão consentir com a participação do estudante assinando este Termo de Consentimento Livre e Esclarecido. Caso haja participantes com idade igual ou superior a 18 anos, ele próprio poderá assinar este termo. Nenhum dos participantes terá gastos financeiros com a pesquisa. Por se tratar de uma pesquisa acadêmica sem fins lucrativos não haverá qualquer compensação financeira pelo uso deste material registrado.

Essa pesquisa não oferece nenhum risco de ordem física aos participantes, entretanto, pelo fato de envolver gravações em áudio e vídeo, podem gerar desconfortos associados a esses meios. Por esse motivo, será garantida a liberdade do participante, seja professor, aluno ou seu responsável, de se recusar a participar ou de retirar seu consentimento em qualquer fase da pesquisa sem penalização ou prejuízo algum. Após análise, a essência do material constituirá a parte empírica da tese de doutorado do pesquisador Alex Bellucco do Carmo, que se compromete trazer nesse trabalho contribuições concretas em relação ao ensino e a aprendizagem da Física, em especial para a educação básica, podendo em certa medida se estender para o ensino superior. $\mathrm{O}$ encerramento da pesquisa se dará após avaliação final do material coletado que será arquivado para possíveis análises futuras e/ou para fins didáticos.

Caso necessitarem de maiores explicações, o pesquisador estará à disposição para esclarecer as dúvidas, pelo correio eletrônico ou pessoalmente.

Alex Bellucco do Carmo

Pesquisador Participante

CONSENTIMENTO DA PARTICIPAÇÃO (assinado pelo(a) estudante)

$E \boldsymbol{u}$,

RG/ CPF

$\longrightarrow$ abaixo assinado, concordo em participar da pesquisa Argumentação matemática em aulas investigativas de física. Fui devidamente informado(a) e esclarecido(a) pela pesquisador Alex Bellucco do Carmo e por meio desse termo sobre a pesquisa, os procedimentos nela envolvidos, assim como os possíveis riscos e benefícios decorrentes de minha participação. Foi-me garantido que posso retirar meu consentimento a qualquer momento, sem que isto me leve a qualquer penalidade ou prejuizo.

Garuva, de de 2013. 
Assinatura

\section{CONSENTIMENTO DA PARTICIPAÇÃO (assinado pelo(a) responsável)}

$\mathrm{Eu}$,

$\mathrm{CPF} \_$abaixo assinado, responsável pelo aluno(a)

, autorizo sua

participação na pesquisa Argumentação matemática em aulas investigativas de física. Fui devidamente informado(a) e esclarecido(a) por meio desse termo sobre a pesquisa, sobre os procedimentos nela envolvidos, assim como sobre os possíveis riscos e benefícios decorrentes da sua participação. Foi-me garantido que posso retirar meu consentimento a qualquer momento, sem que isto leve a qualquer penalidade ou prejuízo a mim ou ao menor.

Garuva, de de 2013

Assinatura 


\section{ANEXO IV - GRAVANDO: O MICROFONE PZM, O PRÉ-AMPLIFICADOR E A FONTE DE ALIMENTAÇÃO}

O Microfone PZM é construído com uma chapa de metal de $10 \mathrm{~cm}$ x $10 \mathrm{~cm}$, um eletreto, um pedaço de calha para fio, cola quente, um cabo blindado e um plugue $P 10^{31}$. Desses materiais, apenas a chapa de metal não é encontrada em lojas de componentes eletrônicos - no nosso microfone reciclamos uma lateral de um gabinete de um computador. Segue uma vista geral do microfone que fica apoiado sobre a mesa (a mesa ajuda a captar melhor as ondas sonoras do ambiente):

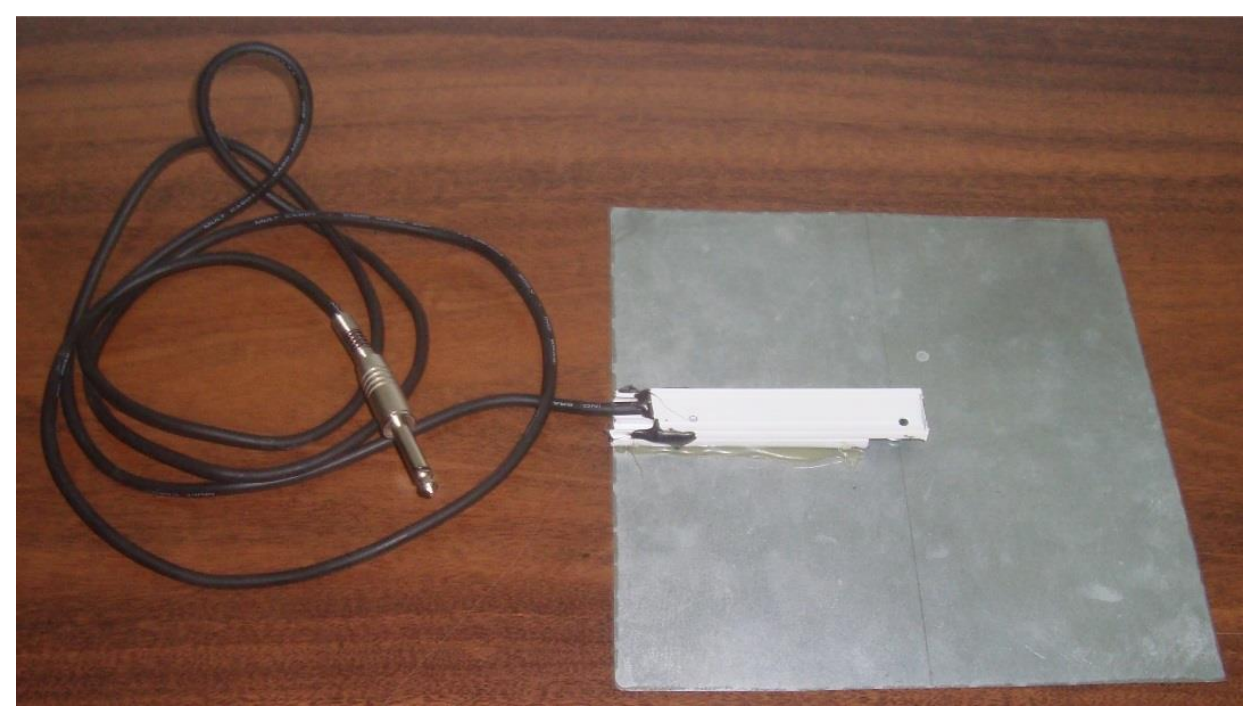

Figura 33: Microfone PZM

O cabo blindado é ligado ao eletreto, sendo a malha do cabo é soldada no polo negativo do eletreto ${ }^{32}$, e o fio do meio do cabo blindado é soldado no outro polo do eletreto.

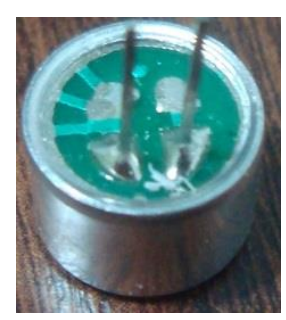

Figura 34: Eletreto

\footnotetext{
${ }^{31}$ Recomendamos que os plugues e jacks sugeridos nesse anexo sejam de qualidade para evitar problemas de captação, como ruídos e mal contato. As marcas Neutrik e Switcraft são as melhores. Usamos também plugues P10 da marca Santo Ângelo com bons resultados.

32 Para identifica-lo basta colocar a ponta de um multímetro em um dos polos do eletreto e a outra na carcaça do eletreto e fazer o teste de continuidade, o polo negativo é o que apita durante esse teste.
} 
O eletreto deve ser fixado com cola quente na calha a uma distância de aproximadamente $1 \mathrm{~mm}$ da placa de metal. A calha deve ser colada na placa de metal, também com cola quente, da seguinte forma:

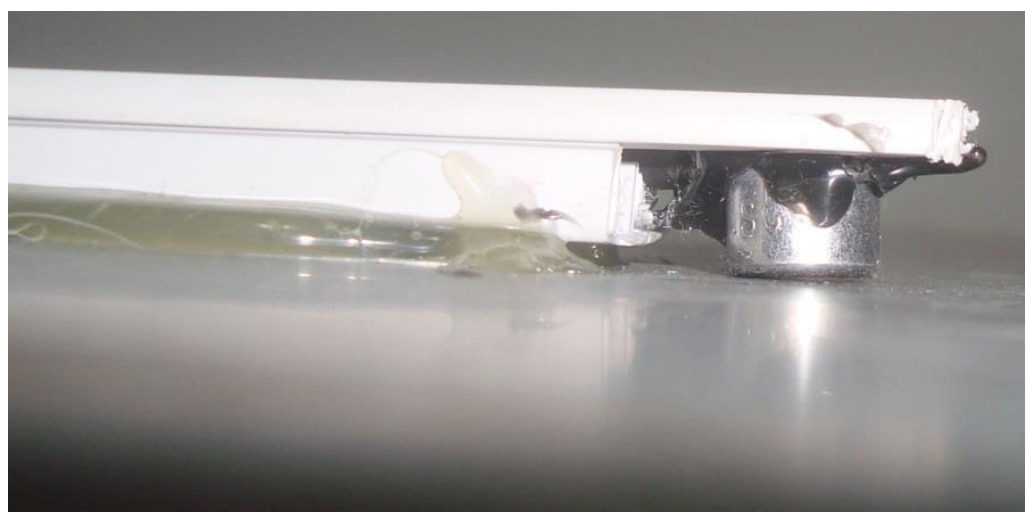

Figura 35: Fixação do eletreto

A outra extremidade do cabo blindado deve ser soldada no plugue P10 da seguinte forma:

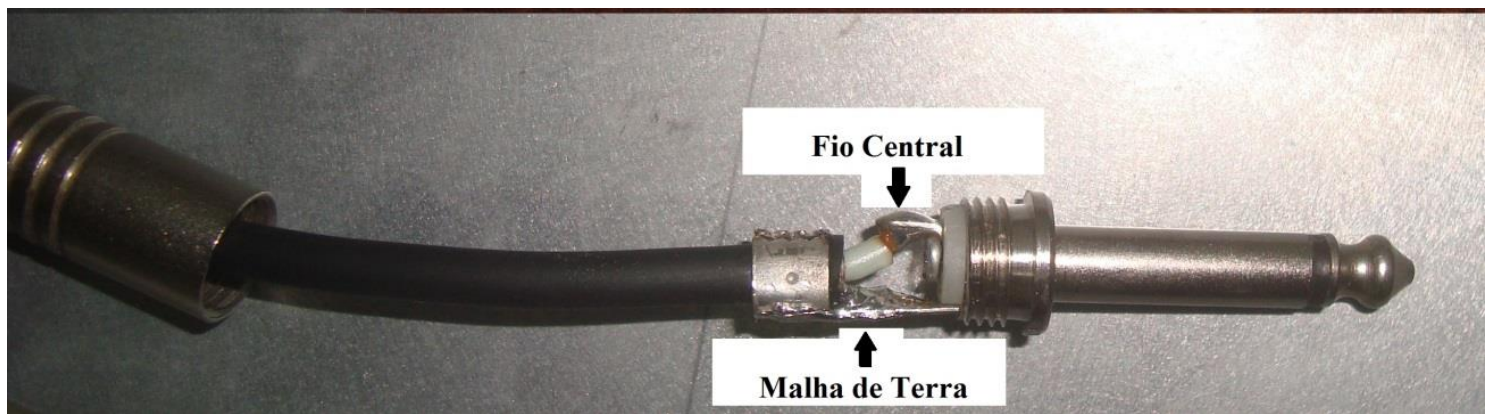

Figura 36: Ligando o plugue P10 ao cabo blindado

O pré-amplificador é baseado no circuito Low Noise Microphone Preamplifier do site Elliot Sound Products ${ }^{33}$ :

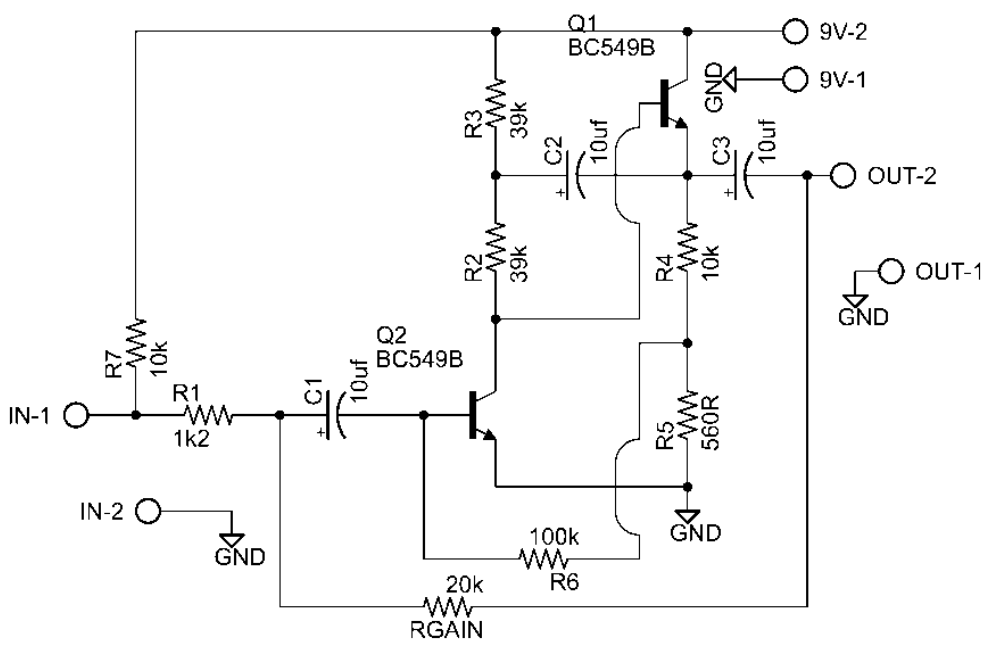

Figura 37: Esquema elétrico do pré-amplificador

\footnotetext{
${ }^{33}$ http://www.sound.westhost.com/project13.htm (acessado em 01 de novembro de 2013).
} 
Incluímos por meio de um resistor de 10k (R7) uma alimentação para o eletreto. O resistor RGAIN regula o ganho do circuito e pode ser trocado por um potenciômetro de 50k, dependendo do gravador utilizado, para ajustar o volume da gravação. No nosso caso deixamos o valor de 20k, pois o gravador Zoom H4n já possui uma regulagem de ganho do microfone. Os pontos 9V1 e 9V2 devem ser soldados respectivamente, por meio de um cabo blindado, aos pinos de terra e de tensão de um plugue $\mathrm{J} 4^{34}$. O plugue P10 deve ser ligado por meio de um jack $\mathrm{J} 10$ mono ao in do circuito da figura 37 , outro jack $\mathrm{J} 10$ deve ser ligado ao out do circuito que deve ir ao gravador:

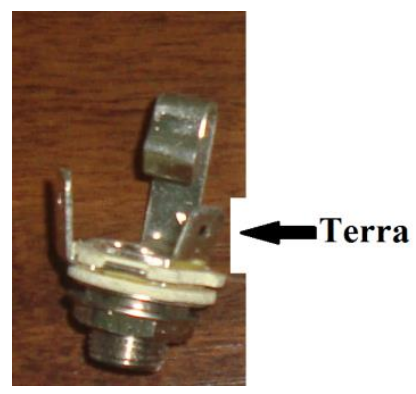

Figura 38: Jack J10

O circuito da figura 37 pode ser construído pode ser construído em uma placa de fenolite ${ }^{35}$ a partir do seguinte layout:

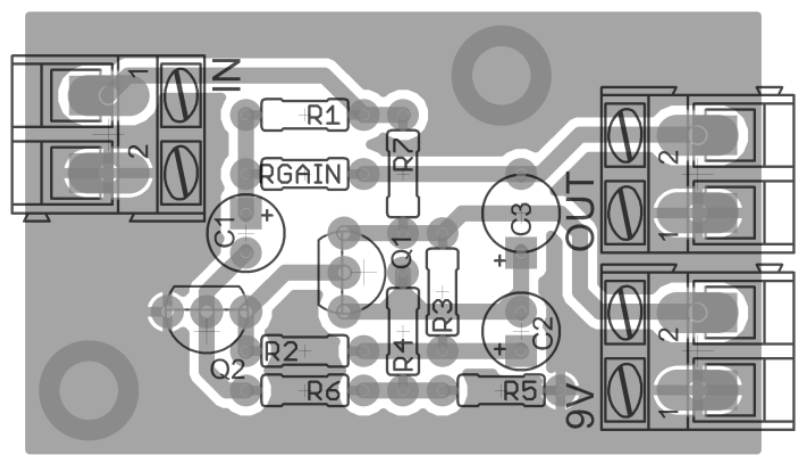

Figura 39: Layout do circuito do pré-amplificador

A figura 40 abaixo mostra os dois circuitos de pré-amplificação confeccionados em uma mesma placa, para usar os dois microfones PZM da pesquisa. É importante usar cabos blindados para ligar os jacks J10 ao pré-amplificador - os cabos na imagem são fixados à placa por meio de bornes KF-128 de dois terminais (componentes quadrados de cor azul na foto), porém eles podem ser soldados diretamente na placa.

\footnotetext{
${ }^{34}$ Mostramos como fazer essa ligação um pouco adiante, ao descrever como construir a fonte de alimentação.

${ }^{35}$ Nesse site há informações úteis sobre como confeccionar a placa e como soldar os componentes na mesma: http://www.handmades.com.br/forum/index.php?page=pci_transfer_term . Tivemos melhores resultados na transferência térmica com glossy paper $150 \mathrm{~g}$.
} 


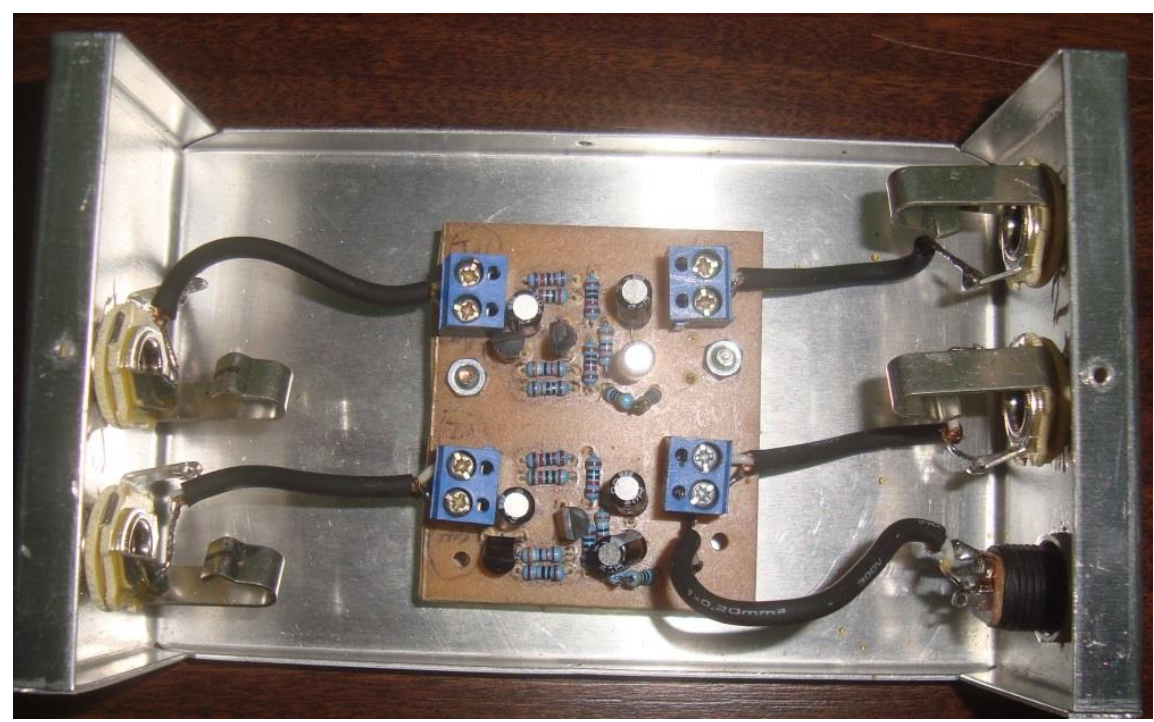

Figura 40: Vista dos pré-amplificadores usados na pesquisa

A seguir dispomos o layout para transferência térmica da placa do préamplificador:

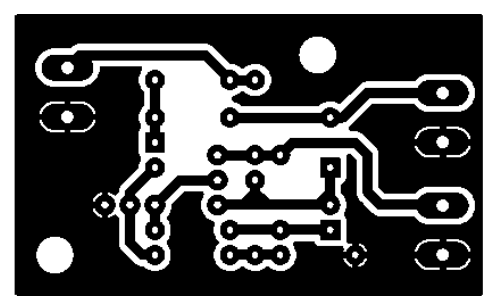

Figura 41: Figura para transferência térmica do layout da placa do circuito do pré-amplificador

O esquema abaixo do circuito da fonte de alimentação foi retirado do site Handmades ${ }^{36}$. Ele é fundamental, pois filtra muito bem os ruídos provenientes da rede elétrica. Recomendamos o uso de capacitores de no mínimo 32V. O pontos AC-1 e AC2 devem ser ligados em um transformador de $12 \mathrm{~V}$ por $250 \mathrm{~mA}$, que deve ser ligado em um cabo e um plugue de tomada.

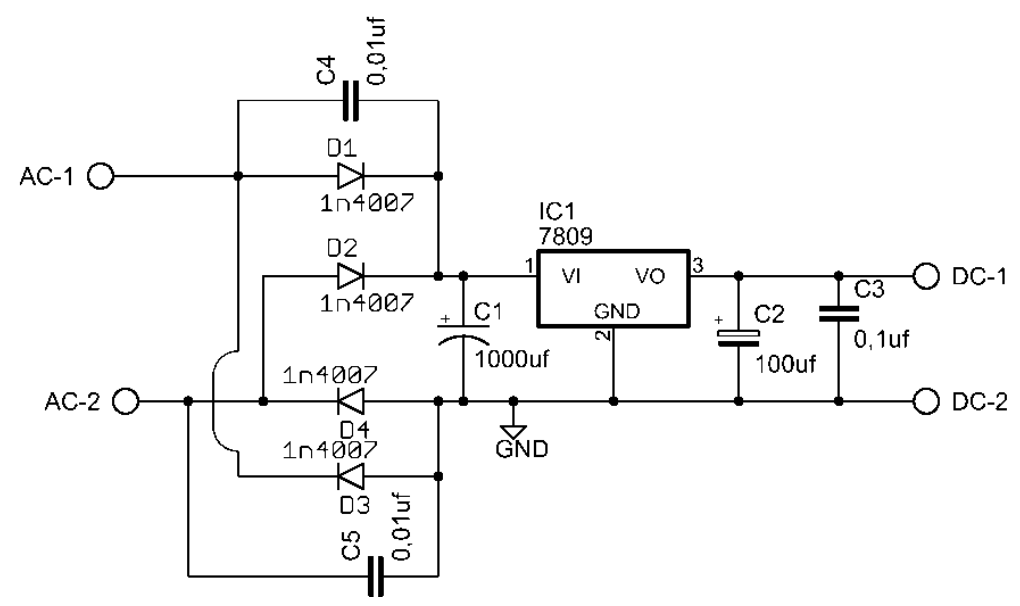

Figura 42: Esquema elétrico da fonte de alimentação

\footnotetext{
${ }^{36}$ http://www.handmades.com.br/forum/index.php?topic=3464.0 (acessado em 01 de novembro de 2014)
} 
Os pontos DC-1 e DC-2 (terra), devem ser ligados a um jack J4:

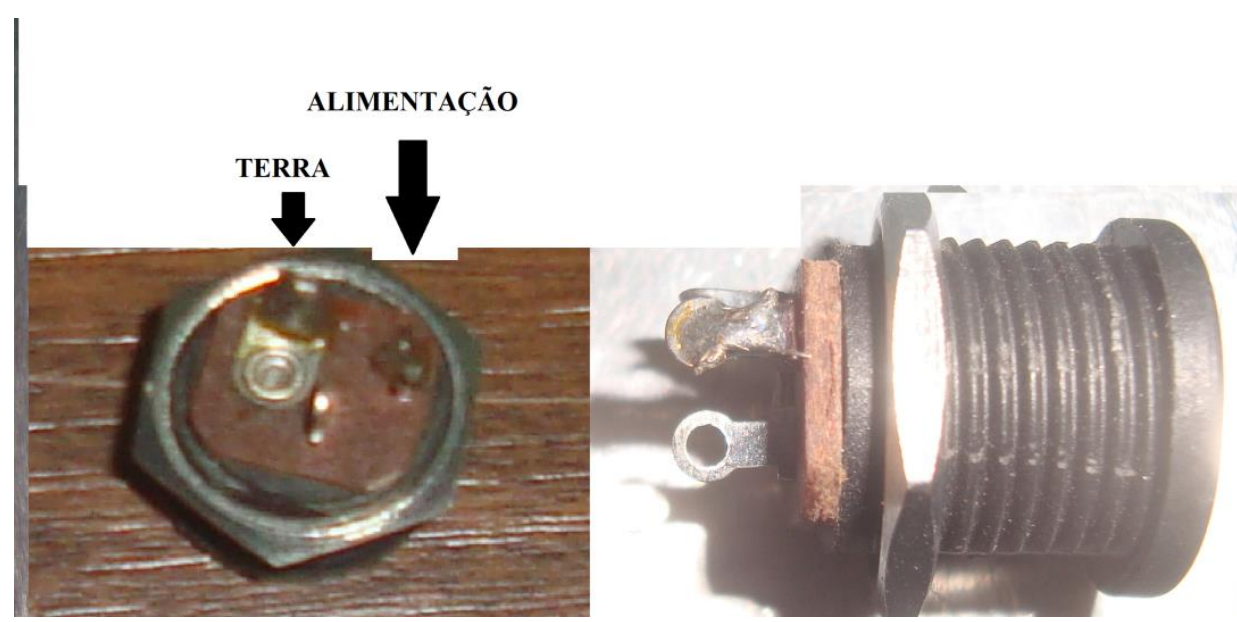

Figura 44: Jack J4

A seguir temos o layout para da placa da fonte de alimentação e a figura para transferência térmica da mesma:

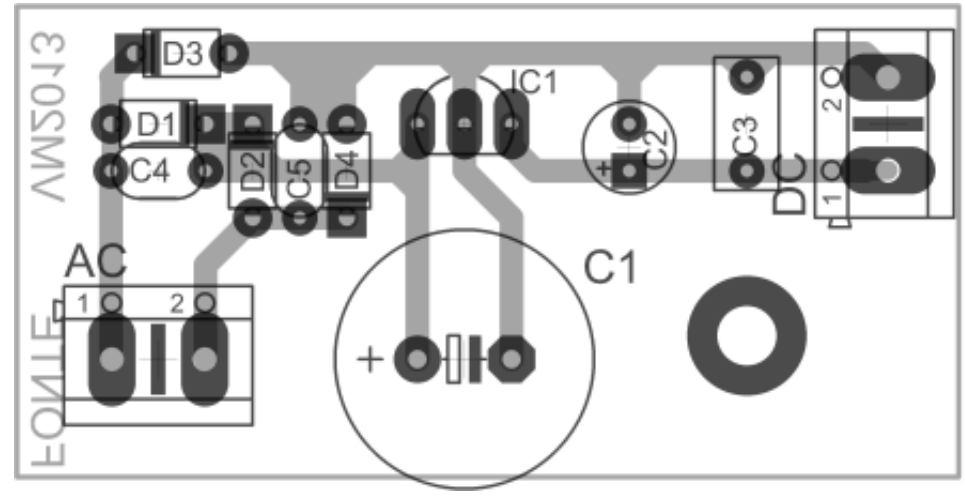

Figura 44: Layout da placa da fonte de alimentação

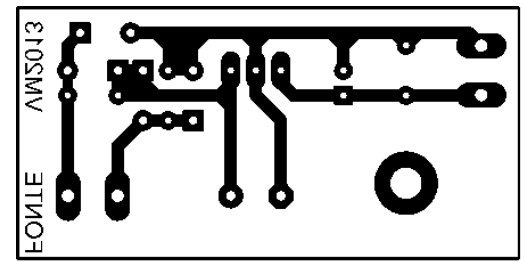

Figura 45: Figura para transferência térmica da fonte de alimentação

São necessários dois jacks J4, um deles deve ser ligado ao pré-amplificador e o outro à fonte. $\mathrm{O}$ pré-amplificador deve ser ligado à fonte por meio de um cabo confeccionado com dois plugues $\mathrm{P} 4$ e qualquer fio duplo: 


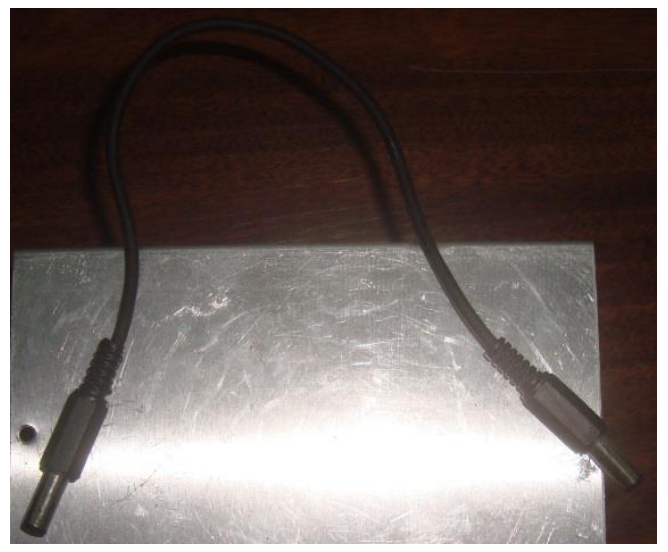

Figura 46: Cabo de ligação entre o pré-amplificador e a fonte de alimentação

Por fim, segue uma imagem geral do aparato (os cabos que vão para o gravador - indicados por "Saída para o gravador" na figura 47 - são feitos com plugues J10 e cabos blindados):

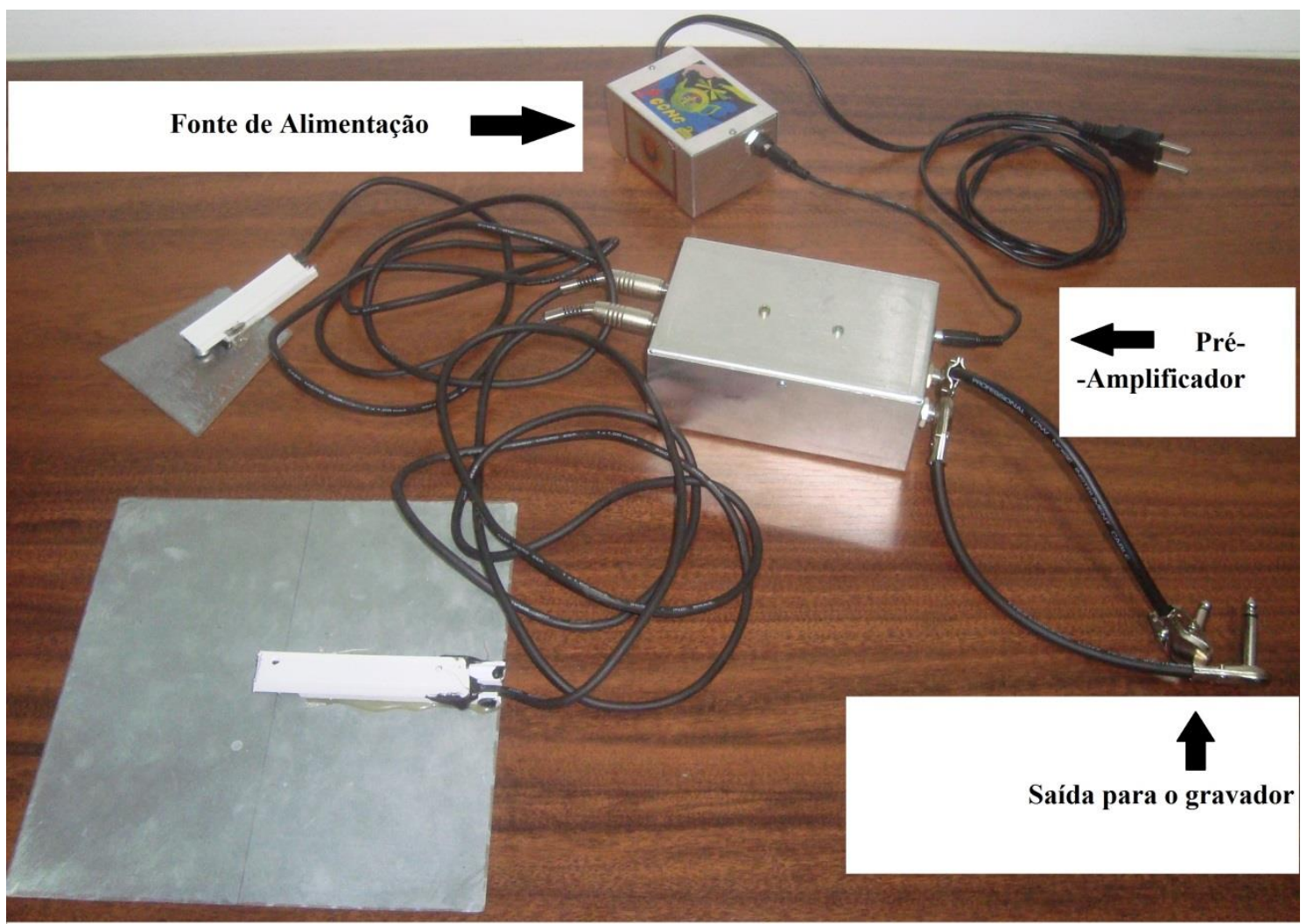

Figura 47: Visão geral do aparato construído para gravação 


\section{ANEXO V - NORMAS DE TRANSCRIÇÃO}

As transcrições foram baseadas em Preti (1997) e Capecchi (2004), em todo lugar que aparecia algum tipo de pausa, foi emprego reticências, com exceção do ponto de interrogação.

Seguem os sinais usados para transcrever as gravações:

() para hipóteses do que se ouviu;

(()) para a inserção de comentários

:: para indicar prolongamento de vogal ou consoante, por exemplo: "éh:.:”;

/ para indicar truncamento de palavras; por exemplo: "o pro/ ... o procedimento...";

- para silabação, por exemplo: “di-la-ta-ção”;

Letras maiúsculas para entonação enfática;

-- para quebras na sequência temática com inserção de comentários.

Usamos ainda /// para indicar falas simultâneas, já que elas são comuns no trabalho em pequenos grupos. 


\section{ANEXO VI - TRANSCRIÇÕES DOS EPISÓDIOS DE ENSINO}

Nas transcrições a seguir, apenas os episódios de ensino selecionados para análise usam o padrão de transcrição de Pretti (1997) adaptado. O tempo de aula é apresentado entre Chevron: 〈tempo>.

\section{Aulas 1 e 2 - 03/05/2013}

<00:00:37> P: Nós vamos fazer uma programação, uma atividade experimental, certo?! $\mathrm{O}$ que a gente vai estudar nesse bimestre? A gente vai estudar o movimento. Bimestre passado a gente já estudou o movimento, né?! Vimos o movimento através do princípio... Só que lá, como eu havia dito pra vocês, lá o movimento é muito superficial onde a gente não levava em consideração algumas grandezas como a massa, certo?! Então nós vamos inserir nesse bimestre o estudo do movimento só que nós vamos levar em consideração agora justamente o que? A massa que está envolvida nesse movimento, ta?! Então, o que é o movimento? O que vocês entendem como movimento? O que é movimento, gente? Se movimentar... Ariel, o que é movimento Ariel? <00:01:36>

$<00: 01: 37>$ A5: Se Mover. <00:01:38>

$<00: 01: 38>$ P: Se movimentar e pra se movimentar você precisa de quê? <00:01:41>

$<00: 01: 43>$ A5: Aceleração. <00:01:44>

$<00: 01: 44>$ P: Aceleração. De que jeito se consegue aceleração? <00:01:47>

$<00: 01: 48>$ A5: Acelerando. <00:01:49>

$<00: 01: 49>$ P: Acelerando como? <00:01:49>

$<00: 01: 50>$ A5: Indo pra frente. $<00: 01: 50\rangle$

$<00: 01: 51>$ P: Indo pra frente, né?! Então tu saberias me explicar por quê a terra gira? O que acelera a terra? A gravidade. O que é a gravidade? Não adianta vocês falarem por falar, tem que pensar um pouquinho. Mas o que iniciou o movimento da terra? E por que ela gira até hoje? A força, então, essas dúvidas de vocês e essas coisas que vocês colocaram a gente vai discutir durante o bimestre inteiro. Nós vamos chegar a algumas conclusões sobre o movimento e a gente vai chegar em uma lei que é fundamental até os dias de hoje e que não pode ser quebrada. Inicialmente eu quero falar com vocês o que é uma lei, então, assim eu vou tentar fazer analogia com vocês como regras de um jogo. Por exemplo, se você for jogar xadrez tu tens " $X$ " número de peças, tem o cavalo, tem o bispo e cada um desses tem um papel fundamental dentro do jogo e cada um pode se movimentar de uma forma e essa forma que ela se movimenta é prevista na regra do jogo e tu não podes infligir essa regra. Então as leis científicas são a mesma coisa, como se fossem regras de um jogo onde tu tens que seguir essas regras e tu não pode infligir essas regras, então a gente vai ver que o movimento segue determinadas regras que a gente não pode quebrar. Então, o seguinte a $1^{\circ}$ atividade que nós vamos fazer aqui é transferir o movimento no problema chamado "O pêndulo de Newton", então vou passar para vocês o pêndulo, um para cada grupo. <00:04:07>

$<00: 04: 38>\mathrm{P}$ : Eu quero que vocês observem esse pêndulo, ele composto de três massas, conseguem observar que duas massas são iguais? E tem uma massa que é menor, conseguem observar isso aí? Muito bem. Olhem só o que é a pergunta da $1^{\circ}$ atividade. 
Fazer um pêndulo, ou seja uma massa, colidir com o outro, então com a outra massa, é possível elevar sempre as bolinhas a mesma altura? Então veja bem eu estou querendo colidir 2 corpos não 3, então como tem 3 corpos vocês tem que destacar 1 corpo fora do pêndulo ou descartem uma massa grande ou descartem uma massa pequena, sugestão do professor descartem a massa grande primeiro, de que forma, levantem ela no pêndulo e coloquem em cima. Agora vocês vão brincar com essas bolinhas, uma está parada e a outra você vai levantar e eu quero saber se é possível abandonando uma massa fazendoa colidir com a outra se essa outra massa levante na mesma altura. Então mãos a obra. $<00: 06: 23>$ $<00: 06: 39>$

P: Vai na mesma altura?

A2: Só quando solta a grande. Daí eu acho que ela vai.

P: Por quê?

A1: Por causa do impacto da força da velocidade quando ela desce

P: O que é força? O que é impacto? Será que não tem outra grandeza que vocês não conseguem enxergar que influencia no movimento? Aqui, larguem a pequena dessa altura aqui, eu vou nivelar aqui, essa pequena aqui será que ela consegue empurrar a grande lá em cima?

A1: Não.

P: Façam depois me digam.

A2: Deixa bem retinha.

A5: Não dá.

A1: Puxa lá.

A2: Vai deixa retinha aqui.

A5: Não vai cara.

A1: Tira a mão.

A2: Vai, solta. Agora solta a grande pra ver. É vai.

A1: Até passa.

A5: Professor! Acho que já sei o que é.

A2: É por causa que essa aqui é mais pesada, ela dá mais impacto.

A5: E essa aqui tem menos massa para quebrar o ar.

A2: Professor, quando solta a pequena ela não vem aqui em cima, mas, quando solta a grande ela passa.

P: Por quê?

A5: Porque essa tem menos massa, por causa do ar.

P: Então concretizem isso, escrevam no caderno tudo isso aí. Quando solta a pequena não vai por quê?

A2: Porque tem menos massa, causa menos impacto.

P: E quando solta a grande o que acontece?

A2: Daí ela passa. Porque tem mais massa e dá mais impacto. <00:08:21> $<00: 08: 58>$

A2: Vai ficar, quando solta o primeiro, quando solta a leve.

A5: Quando solta a pequenininha.

A2: Ela não atinge a mesma altura, por que ela tem menos massa e tem menos impacto.

P: Sugestão que eu dou para vocês que já pegaram é a seguinte, coloquem assim, se organizem, teste $1^{a}$ bola grande parada, levanto a bola pequena, daí vocês vão escrever a bola não sobe na mesma altura porque a massa é menor. Teste $2^{a}$ bola pequena parada, bola grande solta, conclusão: a bola pequena sobe porque a massa é maior. Depois vocês têm que fazer o terceiro teste, o que é o terceiro teste agora? Vocês vão recolher a bola de massa menor e vão ficar com as 2 bolas de massas iguais. 
A2: Daí vai na altura.

A5: Não, não vai.

A2: Bola grande parada, e colocar como daí?

A5: Primeiro teste era bola pequena levantada e a grande parada $<00: 10: 44>$

$<00: 10: 53>$ A3: Bola grande parada e o quê? $<00: 10: 54>$

$<00: 11: 21>\mathrm{A} 2$ - Bola grande parada e a pequena atingida $\langle 00: 11: 26\rangle$

<00:11:55> P: O pessoal posso dar uma sugestão para vocês, pra a explicação? Já vi que vocês entenderam, se você quiser colocar um desenhinho representando a situação, tipo a primeira situação bota o pêndulo parado e a massa pequena se movimentando alta, ok essa é a primeira situação.

A2: Daí depois da para fazer.

P: Você escreve a resposta "Não sobe porque...." entendeu? Segunda situação faz a bolinha pequena parada e a bola de massa maior levantada, tá certo?

A2: Dá pra fazer assim professor, digamos fazer 2 desenhos na $1^{\circ}$ situação a bola pequena erguida e depois ela baixa e pela metade ainda

P: Pode, ótimo, quanto mais você escrever fica melhor pra ti. $\langle 00: 12: 45\rangle$

$<00: 14: 01>$ A2: Vocês vão fazer desenho? Como vocês vão fazer?

A4: Fazer com a bolinha levantada, né?

A2: Ta, mas como que faz a levantada?

A4: Faz um risco.

A1: Faz a maior aqui, e a menor aqui.

A1: Essa é a maior, então faz uma menor ainda. <00:14:19>

<00:14:54> A5: Por que que? Por que a massa é menor, né? E a força de impacto também, é?

A1: O quê?

A5: Por que é? Não alcança a mesma altura porque a massa é menor.

A1: Porque a...

A5: Da bolinha pequena porque a massa é menor e o impacto também é menor.

A1: É. $\langle 00: 15: 19>$

$<00: 15: 51>$ A4: Ergue aquela lá.

A1 - Não dá.

A2: É que tem que deixar elas certinhas. Você tem que deixar aqui na reta. Daí ergue aqui. E ela alcança a mesma altura. Soltando a grande na pequena daí ela passa.

A1: Daí ela passa.

A2: Devido à baixa massa, não devido a baixa força de impacto.

$<00: 17: 38>$ A2: Não alcança a mesma altura devido a baixa massa da bola pequena. $<00: 17: 41\rangle$

$<00: 18: 35>A 2$ : Professor. Aqui eu fiz dois desenhos assim, eu fiz a pequena alta, no ar, daí eu fiz a grande no máximo da altura, daí ela não chego na mesma altura. Vou virar físico, cara. <00:18:53>

$<00: 19: 05>$ P: Pessoal beleza? Então vamos lá, vamos fechar isso ai, vamos ver se nos tivemos as mesmas respostas, vamos lá.<00:19:08>

$<00: 19: 25>$ A5: A bola pequena levantada e a grande parada.

A2: É elas chegam à mesma altura. Essa aqui da pra dizer que ela chega à mesma altura.

A4: Chegam à mesma altura as duas? <00:19:34>

<00:20:40>P: Pessoal, pessoal atenção 1, 2, 3, olhem aqui. Então vamos lá, respondendo a pergunta. É possível ou não é possível quando largar um pêndulo fazer o outro levantar na mesma altura?

Alunos: É possível.

P: Sim, desde que obedeçam a uma regra e qual é a regra? 
Alunos: As massas serem iguais.

P: As massas têm que ser iguais. Então a pergunta é: o movimento depende da massa ou não?

Alunos: Sim.

P: A massa interfere ou não?

Alunos: Sim.

P: Então a massa interfere no nosso movimento. Entendido isso aí, gente? Nós vamos passar para nossa segunda atividade que está proposta que é a questão de colisões. Para existir colisão no mínimo deve existir quantos corpos?

Alunos - Dois.

P: Eu sempre digo em física o seguinte, "um é pouco, dois é bom, três já fíca complicado." Então o nosso estudo vai se ater em colisão entre dois corpos, então eu quero que vocês vejam o que esta colocado aqui e vão fazer a mesma coisa, vão tentar responder essas três perguntas, e eu quero que vocês justifiquem suas respostas, mas, essas justificativas eu gostaria que vocês fizessem baseado naquele trabalho que a gente fez do problema aberto em hipótese. Você vai ter que lançar hipóteses, por exemplo, tu tens a situação 1 que tu tem 1 carro menor e 1 caminhão que é o quê? Maior, o que é maior no caminhão e o que é menor no carro?

Alunos: A massa.

P: Só a massa?

Alunos: O corpo.

P: Quando eu falo tamanho pro homem eu tenho que me ater a uma grandeza que possa ser medida pelo o quê? Massa. Tem que imaginar o que o carro pequeno é a esfera de menor massa e o caminhão é a de maior massa, mas, será que só a massa vai influenciar nesse momento?

Alunos: Não

A5: O peso.

P: O que será mais que influencia?

A2: O tamanho do corpo?

P: O tamanho do corpo em massa, não é o volume do corpo, é a massa do corpo, a gente pode ver que o caminhão obviamente vai ter o quê? Massa maior que o quê? O carro.

A1: O carro.

P: Eu quero que vocês hipotetizem e tentem pensar o seguinte assim, se esse caminhão tiver parado, mas o carro tiver vindo a uma velocidade horrível. $\mathrm{O}$ que é velocidade horrível professor? Velocidade grande. Então isso que eu quero que você hipotetize, se o carro vem com 1 velocidade pequena e bate na traseira do caminhão o que acontece? Se o carro vem com 1 velocidade grande o que acontece com o caminhão?

A5: Vai amassar, vai voar.

P: Eu quero que vocês imaginem o seguinte, na brincadeira do pêndulo ai. Pode fazer essa analogia do pêndulo.

A2: A gente pode bota que o pequeno é o carro e o grande é o caminhão

P: Se vocês quiserem pegar o pêndulo e simularem que o caminhão é a massa grande e o carro é a massa pequena.

A5: Se ele vir devagar ele quase não sai do lugar.

A2: Ele é pequeno, ele é o menor, se ele bater olha, não vai dar, vai dar menos dano no caminhão.

A5: Mas se ele tiver bem rápido, dá um estrago maior.

A2: Professor. Aqui, o carro aqui é o pequeno, né? Daí se ele vir aqui o caminhão quase não se mexe porque ele tem mais massa ele é mais pesado.

P: Mas mexeu 
Alunos: Sim mexeu.

P: O que passou pro caminhão, então?

A2: Energia? Não, força.

P: Não. Uma coisa que a gente viu. Se o carro tava parado o que passou pro carro aqui?

A2: Aceleração?

A5: O caminhão que tava parado.

P: Mas antes da aceleração o que vem? Ele não se movimentou? Então o que passou pra ele?

A2: Movimento.

P: Concorda? O movimento. Carreta, Caminhão, Carreta, faz essa situação, essa é uma situação ok? Isso é uma carreta qual a velocidade que a carreta vai? Tá bom? Agora faz a simulação contrária, carro e caminhão.

A1: Professor se esse carro bater no caminhão o estrago é maior do que se o caminhão bater no carro.

P: Isso vai depender da tecnologia de cada carro, eu quero saber o que consegue transferir para o outro carro.

A1, A5: Movimento.

P: Essa é a palavra. Agora só observem uma coisa, vamos simular que isso aqui é o carro, se eu largar o carro daqui tem diferença?

Alunos: Tem.

P: Qual diferença?

A1 e A2: Dá mais aceleração.

P: Antes da aceleração?

Alunos: Mais movimento

P: Antes do movimento? Qual é a grandeza que a gente viu lá em queda livre, quanto mais alto maior a?

A1: A queda

P: Mais o que aumenta essa queda?

A1: A altura?

A2: O impacto?

P: O que nós pedíamos pra calcular quando tocava no chão?

A2: Impacto?

A4: Velocidade.

P: Então isso que eu quero que você simule aqui, pensa comigo, aqui é uma velocidade, aqui é outra velocidade.

A5: Quanto mais velocidade mais movimento?

P: Simulem, isso que eu quero que vocês simulem.

A1: Qual que é a pergunta? A letra "a". O que acontecerá ....

A2: O que acontecerá com os veículos em todas as velocidades dos carros na "A"?

Nessa figura aqui o caminhão ta parado, né?

A4: É no primeiro tá.

A5: Aqui tá escrito, o que acontecerá com a velocidade...

A2 e A4: ...De todos os carros depois da colisão nas situações 1 e 2 .

A2: Na 1 o caminhão vai diminuir a aceleração. O que acontecerá com a velocidade dos carros depois da colisão. Eles vão parar.

A1: O caminhão vai parar mais perto e o caminhão vai parar mais longe devido ao impacto.

A5: Devido ao movimento. 
A1: Devido ao movimento, se o carro bater no caminhão o caminhão vai andar... $5 \mathrm{~m}$, e se o caminhão, se ele for na mesma velocidade e o caminhão bater no carro ele vai andar $10 \mathrm{~m}$.

A2: Tá, então colocar o que? Colocar que... <00:28:50>

$<00: 29: 41>$

A1: Nós poderíamos colocar aqui na primeira figura com o carro batendo no caminhão... Não vai andar tanto já na segunda se o caminhão bater no carro, o carro pode ir mais longe que o caminhão iria. <0:30:09> $<00: 30: 24>$

A6: Ele ta falando que se o Carro bater no caminhão, o caminhão vai ter menos velocidade do que se o caminhão bater no carro.

A2: É, vai ter menos movimento.

A4:Quanto mais velocidade....

A2: Tá colocar... Na figura 1 quando o carro bate no caminhão ele vai ter menos movimento do que na figura 2 que o caminhão bate no carro. $<00: 30: 46>$

$<00: 31: 20>$

A2: Atividade dois "a", o movimento na figura 1, o movimento do caminhão vai ser menor do que o do carro na figura 2.

A5: Na figura 1 vai ter menos...

A2: Não, ele ta na mesma velocidade, mas, aqui é comparação de massa, é o carro bater no caminhão vai ser um negócio, pode ser a mesma velocidade, mas o caminhão bater no carro...

A4: Quanto mais velocidade mais movimento certo?

A5: Isso.

A2: Mas eles podem estar na mesma velocidade, mas o caminhão vai causar mais movimento no carro, porque ele tem menos massa e menos resistência.

A1: Na primeira figura se o carro bater no caminhão o movimento do caminhão vai ser menor.

A2: Vai ser menor do que na figura 2 que o caminhão bate no carro parado. Mas tem que colocar que o carro bate no caminhão parado.

A1: Então a gente podia colocar aqui que na figura 1 quando o carro bate no caminhão parado

A1 e A2: O movimento é menor.

A1: Do que se o caminhão batesse no carro parado.

A2: Mas na figura 2.

A5: Tá, então na figura 1 o movimento será menor.

A2: Na figura $1 \ldots$

A1: O movimento do caminhão.

A2: Do veiculo parado, daí na figura 2 vai ser o caminhão?

A1: Não vai ser o carro.

A2: Na figura 1 o movimento do caminhão parado vai ser menor do que na figura 2.

A1: Na figura 1 o movimento do caminhão parado será menor do que na figura 2 . Em que o caminhão bate no carro. Podemos dizer que pelo fato de um ter mais massa que o outro...

A2: A pergunta é o que vai acontecer com a velocidade, não precisa explicar. É o que aconteceria com as velocidades dos carros... O professor na "a" porque nos colocamos assim, Na figura 1 o movimento do caminhão parado será menor do que na figura 2 . Em que o caminhão Atinge no carro parado, pode ser assim?

P: Na figura $1 \ldots$

A2: É daí aqui pede qual será a velocidade dos dois veículos depois da colisão. 
P: Tá. Número 1 vocês já responderam né?

A2: Sim. A "a" da dois.

P: O que acontecerá com a velocidade dos carros depois da colisão? Escreve situação 1.

A2: É o carro bate no caminhão.

P: E o caminhão?

A2: Parado.

P: Tá. O que acontece com a velocidade dos dois depois da colisão?

A2: Diminui.

P: De quem?

A2: Do carro diminui e do caminhão aumenta

P: Isso. Por quê?

A1: Por causa da maior massa.

P: Isso! Tem que justificar.

A1: essa é a "b" então agora?

A2: Coloca na figura 1 o carro perde mais velocidade o caminhão ganha...

A5: Eu fiz assim, na figura 1 o movimento do caminhão parado será menor do que na figura dois que o caminhão bate no carro parado por causa da maior massa.

A1 e A2: Agora a "b".

A2: A "b" fica assim, Na figura 1 depois da colisão o carro perde velocidade ganha velocidade. $\langle 00: 36: 16>$

$<00: 36: 26>$ A5: Eu fiz, na figura 1 o carro perde velocidade, daí na figura $2 \ldots$

A2: Depois da batida o carro... Olha na figura 1 depois da batida o carro perde velocidade e o caminhão parado ganha velocidade devido ao... O que você falou pro professor lá? Por causa da diferença de massas?

A5: É

A2: Ele perde devido a diferença das massas. $\langle 00: 37: 10\rangle$

$<00: 37: 45>$

A2: A "b" da dois, devido o que?

A5: Na parte do caminhão?

A1: Devido ao caminhão ter mais massa que o carro.

A2: Na verdade é na primeira, na primeira parte, na primeira figura ele usou. $\mathrm{O}$ carro perde velocidade o caminhão parado ganha velocidade, por quê?

A1: O caminhão tava no zero, tava parado e se alguém bater ele vai ganhar velocidade, ele vai ganha aceleração. Por causa da massa.

A4: Por causa do impacto da massa.

A1: Olha a mesma coisa é aqui, o caminhão parado a coisa bate ele vai pra frente por causa do impacto.

A2: devido a velocidade do $1^{\circ}$ corpo?

A1: Devido a velocidade do impacto

A2: O caminhão ganha velocidade, devido a velocidade e a massa reduzida do veiculo menor. $\langle 00: 38: 49>$

$<00: 39: 27>$

A2: O caminhão ganha velocidade devido a aceleração e a... Professor aquela hora o Jonathan falou para você ali e eu esqueci, o caminhão ganha velocidade quando o carro bate devido a aceleração do...

P: Não

A4: Ganha movimento.

P: O que você consegue observar aqui? Qual é a grandeza que você consegue observar aqui?

A2: Massa e a velocidade. 
P: Sim, só isso.

A2: Devido a massa e a velocidade

P: Agora tem que justificar em fundação da massa ou da velocidade. <00:40:06> $<00: 40: 44>$

A2: Já na figura $2 \ldots$

A1: Já na segunda figura.. qual que é a pergunta... Na segunda figura o caminhão ganhará mais velocidade...

A5: Caminhão?

A1: O carro! Tá o carro ganhará devido o caminhão ter mais massa que o carro.

A5: E mais velocidade.

A1: Não, a velocidade é a mesma.

A5: Então já na $2^{\circ}$ figura...

A1: O carro iniciará com uma velocidade maior...

A4: Mas o carro ta parado, o carro vai ganhar movimento...

A2: O carro vai ganhar mais movimento, é o carro vai ganhar mais movimento...

A5: Devido o caminhão ter mais massa.

A2: Mais movimento, devido... É, devido o corpo em movimento ter mais massa do que o parado. $\langle 00: 42: 39>$

$<00: 43: 06>$

A5: "C", podemos dizer que o movimento de um carro passa para o outro? Sim.

A2: Sim.

A5: Sim, olha aqui como que não passa? Tá parado olha, passou. $<00: 43: 25>$ $<00: 43: 42>$

A2: Por que passa?

A1: Por causa da velocidade. Olha, ele vai ta parado, vem um e bate, ele vai ter velocidade, agora se o caminhão bater no carro ele vai ter mais velocidade, sim ele vai ter uma velocidade, por causa do impacto.

A5: Então nos dois há movimento depois do impacto.

A1: Então.

A5: Por que? $<00: 44: 10>$

$<00: 44: 28>$ A1: Por que a massa de um passa pro outro.

A5: Porque a movimentação de um passa para o outro.

A2: Porque o movimento de um...

A5: Passa para o outro.

A2: Será?

A5: É.

A2: Na hora do impacto? <00:44:38>

$<00: 44: 55>$ P: Vamos lá então, O que acontecerá com a velocidade de todos os carros depois da colisão. O que vocês justificaram? <00:46:08>

$<00: 46: 35>\mathrm{A} 1: \mathrm{Na}$ "a" ...

A2: Na figura 1 depois da batida o carro perde mais velocidade devido... O carro tem menos massa que o caminhão, o carro vai...

A1: Com o impacto o caminhão ira mais perto do que se o caminhão bater no carro.

A2: Como na figura 2.

A1: A diferença é a diferença da massa. Porque o carro tem menor massa.

P: Então na primeira situação? O caminhão ganha ou perde movimento?

A1, A2: Ganha movimento e o carro perde.

P: Por quê?

A1: Por causa da menor massa.

P: E na segunda situação? 
A1, A2: O carro ganha e o caminhão perde.

A2: O caminhão não perde totalmente, ele ainda anda 1 pouco.

P: Centra isso aí, justifica assim, se tu ganha velocidade é por que a sua massa é o que?

Alunos: Menor.

P: Isso é um ponto de vista. O outro ponto de vista é se tu ganha velocidade significa que alguém bateu em?

Alunos: Ti.

P: Então você transferiu o que?

A1: Massa.

A2: Massa não, movimento.

P: Vocês?

A: É na colisão a velocidade do caminhão que estava parado aumenta e a velocidade do carro que estava em movimento diminui. Porque há transferência de velocidade.

P: Correto, mas por que diminui a do outro?

A: Porque a massa do caminhão é maior.

P: Tá certo assim, mas vamos pensar assim, se você está fazendo com que alguma grandeza aumente, você vai fazer uma transferência. Vamos lá.

A: A gente botou que quando o carro bate no caminhão a velocidade do carro diminui, porque o caminhão tem mais massa e por isso o impacto é menor, isso faz com que o carro diminua a velocidade e a velocidade do caminhão aumenta com o impacto. Quando o caminhão bate no carro a velocidade diminui e a do carro aumenta por que o carro tem menos massa que o caminhão isso faz com que o carro seja arremessado para frente e com o impacto o caminhão volte e isso faz com que sua velocidade diminua e a do caminhão também.

P: Muito bem. Isso ai. <00:49:17>

$<00: 50: 35>$ P: As ideias vocês colocaram de forma diferente mais resumido ou mais extenso, seguinte o que acontece com a velocidade? $\mathrm{Na} 1^{\circ}$ situação eu aumento a velocidade do caminhão e diminuo a velocidade do carro, nós estamos criando o que aqui? Uma regra, que quando eu bater em alguma coisa eu vou transferir alguma coisa e essa coisa vai ser o que? Mo-vi-men-to. Então se alguém ganha, alguém tem que perder. Então o caminhão ganha e o carro perde. Na situação dois vai ser a mesma coisa, so que vai ser ao contrario.

Alunos: O carro vai mais longe.

P: Perfeito, então vocês viram que a velocidade, quando eu estou trabalhando com movimento ela vai essencialmente depender o que? Da massa. Então $2^{\circ}$ questão, "o que influencia a velocidade dos carros após as colisões?

Alunos: A massa.

P: A massa. Da para perceber claramente tanto no experimento ou como vocês já partiram para uma coisa assim que tem que pensar mais que é a colisão de dois nomes. E a $3^{\circ}$ ? "Podemos dizer que o movimento de um carro passa para o outro?"

Alunos: Sim.

P: Então você acaba o que? Transferindo o movimento para o outro carro. Isso aqui, só quero que você observem, tenham cuidado com essa experiência, a gente vai fazer, vai matematizar isso aí na próxima aula, mas eu quero que fique bem claro pra vocês o seguinte, que nessa regrinha que estamos vendo agora, você já viu que o movimento depende da massa e da velocidade, a gente viu também outra regrinha agora, vocês acabaram de montar ela que quando eu colido com outro corpo eu passo movimento para esse corpo. Agora uma regra muito importante que vocês tem que observar e que eu queria que vocês notassem no pêndulo de massas iguais, coloquem os dois pêndulos de massas iguais, certo, retire o pêndulo de massa pequena e coloque os de massas 
iguais. E é uma coisa que tem que ficar bem clara para nós que é o seguinte, por que quando eu largo o pêndulo de massa igual o outro consegue chegar lá na mesma altura? Alunos: Por causa da massa.

P: Ótimo, ótimo agora pensando sobre ponto de velocidade, a velocidade vai ser igual?

A1: Sim.

P: Eu vou ter a mesma velocidade? Sim? Por quê?

Alunos: Por tem a mesma massa, são iguais.

P: Perfeito. E agora para "matar a pau" o que você vê quando eu larguei uma bola e ela bateu na outra?

A1: Movimento.

P:Muito bem Alice, eu consegui ver o que aqui? $\mathrm{O}$ movimento. $\mathrm{O}$ movimento sempre vai ser observado. Agora se eu pegar a massa pequena, troquem agora peguei a massa pequena no lugar de uma massa grande, se eu soltar a pequena ou a grande eu vou ver que não consigo chegar na mesma altura.

Alunos: Não.

P: Por quê?

A1: Porque a massa é menor.

Alunos: Porque as massas são diferentes.

P: Agora a pergunta é: eu conservei o movimento ou não conservei?

Alunos: Não.

P: Sim ou não?

Alunos: Não.

P: Sim.

A2: Mas por quê?

P: Por quê? O movimento eu conservei, eu transferi o movimento, agora o seguinte, qual é a dúvida que vocês estão achando que não conservou? Porque a bolinha foi em uma altura menor. Mas por quê ela foi em uma altura menor?

A1: Por que uma tem mais massa.

P: Então o seguinte, conservar o movimento é justamente isso ai, eu transferir integralmente esse movimento para outro corpo. O efeito que eu vou ver e diferente nas massas iguais e nas massas o que? Diferentes. Eu vou trocar então o que? Massa por velocidade, então eu não consigo perceber quando eu tenho massas diferentes, velocidades iguais. Tranquilo isso ai? Olha só eu quero que vocês pensem comigo agora, eu vou definir uma regra aqui, $1^{\circ}$ regra o movimento depende da massa, $2^{\circ}$ movimento depende da velocidade e a $3^{\circ}$ regra é que esse meu movimento se conserva, o que eu consigo fazer é transferido de um corpo para outro, mas esse movimento se conserva, então tem coisas que é fácil de eu observar e tem coisas que é difícil de observar. Por exemplo, quando eu pego essas duas massas iguais, você consegue observar que o movimento se conserva, por que as massas são?

Alunos: Iguais.

P: Agora quando eu peguei massas diferentes, eu já tive o que? A dificuldade, mas o movimento se conserva, olhem aqui, eu vou fazer este experimento agora, eu vou pegar essa caneta e vou larga no chão e a pergunta que eu vou fazer para vocês é a seguinte. Eu empurrei a Terra para baixo ou não?

Alunos: Não

P: Eu vou pegar a caneta e quero saber se eu vou empurrar a terra para baixo. Vou fazer essa pergunta diferente. Bolinha pequena do pêndulo e bolinha grande, empurro ou não empurro a bolinha?

Alunos: Empurra.

P: Então, de novo, Caneta...Empurra a Terra ou não? 
Alunos: Empurra.

P: Mas vocês conseguem visualizar isso ai?

Alunos: Não.

P: Por quê? Porque olha o tamanho da massa da Terra e olha a massa dessa caneta. Vai ser o que? Imperceptível, certo? Obedecendo isso ai, as regras que a gente viu massa, velocidade e eu acabo o que? Transferindo o que? Movimento para Terra, agora olha a massa da terra. A pergunta é, eu transferi o movimento total dessa caneta para a Terra?

Alunos: Sim

P: O movimento se conservou, agora eu não consigo ver esse feito devido ao tamanho do que?

Alunos: Da massa.

P: É a mesma coisa que aconteceu com o pêndulo, quando vocês pegaram duas massas iguais, vocês conseguiram identificar que os movimentos se conservaram e quando vocês pegaram uma massa pequena e uma massa grande tiveram o que? Dificuldade, mas então é correto afirmar independente do tamanho das massas esse movimento vai o que? Se conservar. Algum pergunta? Para finalizar, vou fazer uma perguntinha para vocês, se eu tivesse que medir esse movimento, eu daria um nome pra ele por exemplo, você mede velocidade, mede aceleração, mede tempo, mede força, mas se eu tivesse que medir esse movimento, certo, esse movimento dependeria de duas grandezas, quais seriam essas duas grandezas?

Alunos: Massa e velocidade.

P: Isso que a gente chama de quantidade de movimento ou antigamente no tempo de Newton ele chamou de momento linear, então a quantidade de movimento pra nós hoje vai ser uma grandeza que a gente vai equacionar na lousa depois, vai se chamar de quantidade de movimento e nada mais vai ser que a multiplicação massa e sua velocidade, ta certo? Então quando eu tiver falando de quantidade de movimento eu to falando de massa e to falando de movimento. Perguntinha, se nesse exato momento estivesse voando um mosquito e eu vou daqui correndo em direção a ele, nós vamos se colidir, concordam? A pergunta é a seguinte a quantidade de movimento se conserva ou não?

Alunos: Sim.

P: Sempre vai se conservar, ou ele vai passar um pouco de movimento para mim ou eu vou passar para ele. Seguinte nesse incidente que vocês viram, nessa colisão vocês viram que a massa é importante, mas o que é importante também? A velocidade, quando eu tiver analisando quantidade de movimento eu não posso analisar só a massa, eu tenho que analisar o que também? A velocidade. Ok? Eu tenho também que analisar a velocidade. Alguma pergunta? Eu quero que vocês coloquem no caderno, escrevam ai, quantidade de movimento, e embaixo nós vamos equacionar isso ai, nós vamos representar a grandeza quantidade de movimento com a letra "Q" maiúscula de queijo, vamos representar a quantidade de movimento com a letra "Q". Então em baixo você imagina que nós vamos fazer equação tipo aquela "Deus vê tudo", então você vai botar a letra " $Q$ =" e vai escrever "Massa x Velocidade" pode abreviar se quiser "M . V". Se é uma grandeza nova o que estamos vendo aqui certo, ela tem que ter uma unidade de medida, $\mathrm{m} / \mathrm{s}$ (metros por segundo), qual vai ser a unidade de medida dessa grandeza? Então você vai botar o seguinte, escreva do lado unidade de medida, está multiplicado ali massa por?

Alunos: Velocidade

P: Não falei a unidade de massa, $\mathrm{Kg}$ e velocidade m/s, então eis a unidade " $\mathrm{Kg}$. m/s", essa é a unidade de medida podem colocar em baixo. 


\section{Episódio 1 - Pêndulo de Newton, questões abertas e problema fechado}

\begin{tabular}{|c|c|c|}
\hline $\begin{array}{l}\text { Tempo inicial e } \\
\text { final da cena }\end{array}$ & \multicolumn{2}{|c|}{ Transcrição, Descrição das ações e linguagens } \\
\hline 01:04:40-1:09:55 & \multicolumn{2}{|c|}{$\begin{array}{l}\text { P: Agora para dizer que não fizemos conta em física... né? Tem que ter uma } \\
\text { continha... ((alunos debocham)) então coloquem aí exemplo... agora vamos ao } \\
\text { nosso imaginário.... do lado esquerdo vocês vão desenhar um caminhão igual } \\
\text { este da folhinha((sobre a atividade } 2)) \ldots \text { ((alunos perguntam se é para fazer a } \\
\text { lápis e comentam que não sabem desenhar)) coloquem aí a massa do caminhão } \\
\text { "cinco mil quilogramas"... e coloquem a velocidade do caminhão aí... "cinco } \\
\text { metros por segundo"... beleza? Agora do lado oposto vocês vão desenhar um } \\
\text { carrinho pequeno... de frente para o caminhão... a massa do carro "mil } \\
\text { quilogramas"... coloquem aí a velocidade do carro "vinte e cinco metros por } \\
\text { segundo"... ((professor resolve algumas dúvidas de alguns grupos))... agora a } \\
\text { pergunta... Qual dos carros possui a maior quantidade de movimento antes da } \\
\text { colisão? } \\
\text { A10: Vai bater professor ((sobre o sinal)). } \\
\text { ((Grupo de análise comenta entre si)) A5: Então deixa que bate... a gente fica } \\
\text { um pouco mais depois cara... é legal cara. } \\
\text { A2: Muito legal... essa aula tá show... } \\
\text { A5: Quer estudar ((inaudível)) cara? } \\
\text { A6: É... um mês... } \\
\text { A2: É a primeira vez que eu estudei na vida ((colegas riem)). } \\
\text { P: Óh... Vocês têm um minuto para fazer essa questão ((alguns alunos ficam } \\
\text { surpresos)). } \\
\text { A2: Mas como que faz essa conta? Mas como que faz essa conta A6? O seu } \\
\text { animal era de frente que o carro. } \\
\text { P: AQUI Ó... Antes de vocês fazerem, quem acha que o caminhão tem a maior } \\
\text { quantidade de movimento erga a mão? Ergue a mão aí ((alguns alunos levantam } \\
\text { a mão)). }\end{array}$} \\
\hline $\begin{array}{l}\text { Tempo inicial } \\
\text { e final da cena }\end{array}$ & Transcrição, Descrição das ações e linguagens & Ciclo Argumentativo \\
\hline \multirow[t]{3}{*}{$\begin{array}{l}01: 09: 55- \\
01: 10: 15\end{array}$} & \multirow{3}{*}{$\begin{array}{l}\text { A2 ((falando só para os colegas)): Nós aqui é o carro... nós } \\
\text { é o carro. } \\
\text { A11: Os dois é a mesma. } \\
\text { A9: Os dois é a mesma. } \\
\text { A6 - É A MESMA os dois... porque cinco dividido... vinte } \\
\text { e cinco dividido por cinco é cinco. } \\
\text { P: Vamos lá? Rapidão... } \\
\text { A2: É a mesma. } \\
\text { A6: É o mesmo. } \\
\text { Aluno de outro grupo falando para A6: Quantidade de } \\
\text { movimento depende de massa e de velocidade... um tem } \\
\text { maior massa e o outro tem maior velocidade. }\end{array}$} & $\begin{array}{c}\text { Definição de variáveis } \\
\text { Explicação }\end{array}$ \\
\hline & & Argumentação \\
\hline & & $\begin{array}{c}\text { Previsão } \\
\text { Abdução } \\
\text { Justificativa } \\
\text { Raciocínio lógico } \\
\text { proporcional }\end{array}$ \\
\hline $\begin{array}{c}\text { Tempo inicial e } \\
\text { final da cena }\end{array}$ & Transcrição, Descrição das ações e linguagens & Ciclo Argumentativo \\
\hline \multirow[t]{2}{*}{$\begin{array}{l}01: 10: 15- \\
01: 10: 45\end{array}$} & \multirow{2}{*}{$\begin{array}{l}\text { A1- OH PROFESSOR... Professor é a mesma... } \\
\text { A?: É a mesma professor. } \\
\text { A1: porque um tem a menor massa... mas o outro tem a } \\
\text { maior velocidade ((Professor acena positivamente com a } \\
\text { cabeça)). } \\
\text { A?: É. } \\
\text { A5((Falando para A6)): TÁ... o que tem a menor massa é o } \\
\text { que tem... /// A1: Tem a maior quantidade }\end{array}$} & $\begin{array}{l}\text { Definição de variáveis } \\
\text { Explicação }\end{array}$ \\
\hline & & \\
\hline
\end{tabular}




\begin{tabular}{|c|c|c|c|}
\hline & \multicolumn{2}{|c|}{$\begin{array}{l}\text { A5: ... é o que tem a menor massa... /// A6: Não... o que } \\
\text { tem a maior massa tem a menor velocidade e o que tem } \\
\text { menos massa tem maior velocidade. } \\
\text { A2- Sim... mas tu falou que o que tem menos massa tem } \\
\text { maior velocidade. } \\
\text { A6: Então o que tem menos massa tem a maior velocidade } \\
\text { ((aponta para o caderno)). } \\
\text { A2: E o que tem menor massa tem mais velocidade. } \\
\text { A6: Não... ((alunos dispersam um pouco)). }\end{array}$} & $\begin{array}{c}\text { Dedução } \\
\text { Justificativa } \\
\text { Raciocínio lógico } \\
\text { proporcional }\end{array}$ \\
\hline $\begin{array}{l}\text { Tempo } \\
\text { inicial e final da } \\
\text { cena }\end{array}$ & \multicolumn{3}{|c|}{ Transcrição, Descrição das ações e linguagens } \\
\hline 01:10:45 - 01:11:00 & \multicolumn{3}{|c|}{$\begin{array}{l}\text { P((falando para o grupo)): Era para calcular... vocês calcularam? } \\
\text { A4: Professor vai bater o sinal... tem que guardar o material ainda. } \\
\text { P: Tem cinco minutos ainda. } \\
\text { A4: Mas eu tenho que guardar o material. } \\
\text { A1: Ir para casa para quê? } \\
\text { A5: Nós também... você não é a única. } \\
\text { A6: É... você não é a única. } \\
\text { P: Rápido rápido rápido... é individual. ((professor vai ajudar outros grupos)). }\end{array}$} \\
\hline $\begin{array}{l}\text { Tempo inicial } \\
\text { e final da cena }\end{array}$ & Transcrição, Descrição das ações e lì & guagens & Ciclo Argumentativo \\
\hline \multirow[t]{3}{*}{$\begin{array}{l}01: 11: 00- \\
01: 11: 20\end{array}$} & \multirow{3}{*}{\multicolumn{2}{|c|}{$\begin{array}{l}\text { A2: O professor a gente está tentando pensar. } \\
\text { A1: A gente tem que dividir, né? } \\
\text { A2: Já pensou aí como se faz? ((alunos escrevem no } \\
\text { caderno)). } \\
\text { A1: Dividi né? } \\
\text { A2: Cinco dividido por... /// A5: Os dois tem mesma... } \\
\text { A6: Cinco. } \\
\text { A5: Vinte e cinco divido por cinco é cinco. } \\
\text { A1: Tem que divi/... tem que soma/... tem que fazer a } \\
\text { conta... } \\
\text { A3: Tem que fazer aquela V1. } \\
\text { A6: Então. } \\
\text { A3: Então... é aquilo que tem no caderno... pesquisa no } \\
\text { caderno que você (acha). }\end{array}$}} & $\begin{array}{l}\text { Definição de variáveis } \\
\text { Explicação }\end{array}$ \\
\hline & & & Argumentação \\
\hline & & & $\begin{array}{c}\text { Abdução } \\
\text { Dedução } \\
\text { Justificativa }\end{array}$ \\
\hline $\begin{array}{l}\text { Tempo inicial } \\
\text { e final da cena }\end{array}$ & \multicolumn{2}{|c|}{ Transcrição, Descrição das ações e linguagens } & Ciclo Argumentativo \\
\hline \multirow[t]{3}{*}{$\begin{array}{c}01: 11: 20- \\
01: 11: 50\end{array}$} & \multirow{3}{*}{\multicolumn{2}{|c|}{$\begin{array}{l}\text { A2: ((escrevendo e falando)) Vinte e cinco dividido por } \\
\text { cinco... Quanto que é Vinte e cinco dividido por cinco? } \\
((\text { para A1)) /// A4 ((para A5)): E o seu caderno... deixa eu } \\
\text { ver o seu caderno. } \\
\text { A5: Quanto? } \\
\text { A1: Cinco ((alunos anotam no caderno)). } \\
\text { A5: O que é isso cara? } \\
\text { A2: Cinco... e quanto é cinco mil...?... cinco mil é três zero, } \\
\text { certo? ((colegas riem)) } \\
\text { A1 ((em tom de deboche)): Eu acho que sim. } \\
\text { A5: Você está de brincadeira? } \\
\text { A6: É cinco? ((depois de fazer as contas em seu caderno)). } \\
\text { A2: Vai dar a mesma coisa. }\end{array}$}} & Definição de Variáveis \\
\hline & & & Argumentação \\
\hline & & & Dedução \\
\hline $\begin{array}{c}\text { Tempo } \\
\text { inicial e final } \\
\text { da cena }\end{array}$ & $\begin{array}{c}\text { Transcrição, Descrição das ações e } \\
\text { linguagens }\end{array}$ & \multicolumn{2}{|c|}{ Ciclo Argumentativo } \\
\hline \multirow[t]{2}{*}{$\begin{array}{l}01: 11: 50- \\
01: 12: 10\end{array}$} & \multirow{2}{*}{$\begin{array}{l}\text { P: Vamos lá então? } \\
\text { A2: Aí dá cinco... dá a mesma coisa. } \\
\text { P: Qual é a quantidade de movimento maior? } \\
\text { A6: Cinco } \\
\text { Vários alunos: São iguais. }\end{array}$} & \multicolumn{2}{|r|}{ Explicação } \\
\hline & & \multicolumn{2}{|c|}{ Argumentação } \\
\hline
\end{tabular}




\begin{tabular}{|l|l|c|}
\hline & $\begin{array}{l}\text { A9: Os dois vão o mesmo número de } \\
\text { movimento ((inaudível)). } \\
\text { A7: A massa de um é maior... mas a } \\
\text { velocidade do outro é maior... }\end{array}$ & $\begin{array}{c}\text { Dedução } \\
\text { Justificativa }\end{array}$ \\
\hline
\end{tabular}

Aulas 3 e $4-10 / 05 / 013$

$<0: 00: 14>$ A5: É difícil, agora que entendi, é difícil andar para...

$<0: 00: 23>$ A2: Vamos ler o desafio...

$<0: 00: 25>$ A5: É, o desafio... (todos leem individualmente, sons dos outros grupos atrapalham).

$<0: 00: 45>$ A5(boné vermelho): Então tem que pegar uma folha e fazer esse, tipo, quando move, o chão vai pra trás, alguma coisa vai pra trás.

$<0: 00: 53>$ A1 (gordinho): Alguma coisa vai pra frente, né?

$<0: 00: 59>$ A5: Ai, meu Deus.

$<0: 01: 04>$ A1: Usa um pouco de lógica, né?

$<0: 01: 10>$ A5: O Marcão olha direto na tua cara (risadas)

$<0: 01: 18>$ P: Pessoal, só uma observação: bem no final do texto ali, tá escrito para elaborar dois exemplos, então, diante dessa leitura, vocês discutam com o grupo dois exemplos, tá?

$<0: 01: 31>\mathrm{A}$ (aleatório1): É pra escrever nessa folha aqui?

$<0: 01: 34>$ P: É pra escrever no caderno, essa folha pode colar no caderno, tá?

$<0: 01: 37>$ A(aleatório2): Professor! Mas igual ali pede pra fazer numa folha pra entregar pro professor.

$<0: 01: 42>\mathrm{A}$ (aleatório3): Mas é pra fazer como o professor falou.

$<0: 01: 45>$ P: Não sei assim, se vocês entenderam, eu e o professor Alex vamos precisar xerocar os cadernos de vocês depois, tá?

(Professor fala com professor Alex: acho que dá pra fazer um caderno, só xerocar. Professor Alex responde: Tudo bem!)

$<0: 02: 06>$ P: Pode colocar essa folha e deixar, tá? Daí assim, ó, depois a gente vai conversar. Essa parte do (...) o professor Alex vai precisar depois, então a gente vai pedir pra vocês tirarem xerox, a gente vai pagar, tá? Só que a gente precisa ter como documento isso aqui para anexar lá nos estudos do professor, tá? Depois a gente combina, vê quantas folhas vai sair e dá o xerox que a gente vai repassar pra vocês aí, ok?!

$<0: 02: 40>$ A5: Bóra colocar o caderno em dia, né?

$<0: 02: 41>$ A1: Bem nessa, bem nessa.

$<0: 02: 43>$ (entre alunos) Discussão sobre como colarão a folha no caderno.

$<$ 0:03:00 $>$ (entre alunos) Discussão sobre a atividade da aula passada, se fizeram ou não.

$<0: 03: 13>$ P: Pessoal! Quem faltou a última aula, eu gostaria que vocês colocassem (...), tão vendo que aqui tem a primeira atividade aqui que vocês responderam na última aula, certo? Todo mundo fez? Certo, essa atividade aqui, tá? Atividade 2, atividade 4, e depois a atividade 3 a gente vai trabalhar hoje.

$<0: 04: 10>$ Discussão sobre como colocar atividades no caderno.

$<0$ :04:34> A5: Qual vai ser os exemplos, cara? 
$<0: 04: 37>$ A6: Eu não entendi! Não entendi nem o texto.

$<0: 04: 42>$ A5: Olha, aqui diz/explica que quando você anda pra frente é como se tu empurrasse alguma coisa pra trás, não é? Quando tu vira pra direita.

$<0: 04: 56>$ A2: Automaticamente essa coisa vai pra esquerda.

$<0: 04: 57>$ A5: Alguma coisa vai pra esquerda, isso!

$<0: 05: 00>$ A2: Quando vai pra frente, alguma coisa vai pra trás...

$<$ 0:05:03> A5: Quando um carro sai arrancando, batendo marcha, ele empurra o chão pra trás.

$<0: 05: 08>$ A6: Não empurra o chão pra trás, o chão vai estar fixado.

$<0: 05: 13>$ A5: Lê esse negócio aqui, cara, tu vai entender se tu ler.

$<0: 05: 14>$ A6: Eu li, cara, eu li.

$<0: 05: 15>$ A5: Não cara, não leu. Ele diz a mesma coisa que eu falei,

$<0: 05: 16>\mathrm{A} 1$ : Ariel, tu marcou alguma coisa?

$<0: 05: 20>$ A1 (se referindo à A3): Marcou alguma coisa no texto?

$<0: 05: 22>$ A3: Não.

$<$ 0:05:24> A6: Professor, eu não vou colar, eu pego as duas folhas aqui, deixo aqui, porque isso aqui é fora disso, daí eu chego em casa e passo a limpo isso aqui.

$<0$ :05:33 $>$ P: Beleza. É que isso aqui, eu gostaria assim, ó, tu colocou assim, (pede emprestada a outra folha para os alunos). Essa aqui, a primeira atividade aqui, deixa eu mostrar (mexe no caderno do aluno), gostaria que recortasse e colasse aqui, ó, a segunda atividade, é essa que a gente tá fazendo aqui, esse tipo de coisa, daí a terceira atividade, isso daqui, tá bom?

$<0: 06: 10>$ A5: Tá, mas e o exemplo? Eu pensei no avião, cara, quando ele sobe, alguma coisa desce.

$<0: 06: 23>$ A2: A Terra desce, o chão fica aqui...

$<0: 06: 30>$ A6: Não, não é que a Terra desce, a Terra não desceu.

$<0: 06: 32>$ A5: Alguma coisa tem que descer, não é o que o texto tá falando?

$<0$ :06:37> A6: Mas não é só porque o avião subiu que a Terra vai descer, a Terra tá parada.

<0:06:38> A5: Não, não, não to falando que a Terra vai descer, só que quando alguma coisa sobe, quando digamos tu sobe, alguma coisa desce, tipo, tu sobe, vai olhando, parece que alguma coisa tá descendo.

$<0: 06: 51>$ A6: Toda vez que eu pulo, meu celular cai, tá valendo?

$<0: 06: 54>$ A5: Pô, cara, na moral, cara. Que chato!

$<0: 06: 59>$ A2: Como é que é?

$<0: 07: 00>$ A5: Que nem ó, quando tu cai de cima de um, quando tu vai pular o muro, tá ligado? Tu faz essas coisas, né? Tu que tá pulando, tu olha assim, parece que as bagaças estão indo pra cima, não estão?

$<0: 07: 11>$ A2: Depende..

$<0: 07: 13>$ A1: Quando tu anda de carro, quando tu anda de carro tu olha pra paisagem, a paisagem parece que tá indo pra trás, tu que tá indo pra frente...

$<0: 07: 17>$ A5: Parece que tu tá parado e que as bagaças que tão vindo em tu, é isso que ele tá falando aqui...

$<0: 07: 20>$ A2: Eu sei, eu já entendi isso...

$<0: 07: 22>$ A5: Então, mas a mente fraca aqui (se referindo ao A6)...

$<0: 07: 23>$ A6: Eu entendi, só tava zoando...

$<0: 07: 27>$ A2: Então vamos usar o exemplo do avião?

$<$ 0:07:28> A5: Não. Fazer um F22, ele assim (mostrando com a mão o movimento), de repente ele pega e sobe assim.

$<0: 07: 35>$ A1: Não sei se vocês perceberam, mas o A5 (Renan) gosta de avião. 
$<0: 07: 39>$ A5: Tem avião que faz isso, cara! Aqueles avião que vão assim e depois eles sobem direto.

$<0: 07: 45>$ A1: Imaginação fértil já.

$<0: 07: 47>$ A5: Não, mas tem mesmo, tu nunca viu? Eu vou baixar o vídeo, passar pro celular, você vai ver e vai ficar de cara. Vocês viram, são uns aviões de manobra.

$<$ 0:08:02> A1 (estressado): Tá, A5, mas o negócio é Física agora, não avião, velho.

<0:08:03> A5: Mas eu to dizendo, tentando explicar, cara, porque tu... A1 (Lucas)

esqueceu de tomar o remedinho antes de vir pra cá? Que exemplo que vamos fazer, vocês não falam nada.

$<0: 08: 16>$ A2: É difícil de fazer, cara, não tenho nada na cabeça...

$<0: 08: 19>$ A3: O do carro, faz o do carro.

$<0: 08: 20>$ A5: Mas tem que ser um que não tá aqui, o do carro tá aqui (se referindo ao papel).

<0:08:25> A6: O do avião dá a impressão... quando você pula, dá a impressão de que alguma coisa sobe e você desce.

$<0$ :08:34> P: Então, pessoal, fizeram os exemplos?

$<0: 08: 40>$ Sala toda: Não

$<0: 08: 42>$ P: Estão terminando os exemplos...

$<0: 08: 42>$ A6: Fazer...

$<0: 08: 47>\mathrm{P}$ : Tem alguma coisa no texto que vocês leram que vocês não entenderam?

Tá tudo entendido? Simples? Tá tranquilo isso aí? Bom, então só vamos dar uma retomada da aula passada, o que a gente viu, a gente fez uma atividade experimental lá, pra estudar o movimento, a gente percebeu que o movimento agora é uma coisa que não depende só da velocidade, ele depende também da sua? Massa. Da massa de cada corpo, certo? E a gente viu também que quando a gente interage com dois corpos, a gente vai ter uma causa e um efeito, onde que a gente pode ver que o efeito depende da sua massa. Se eu colidir um corpo com mais massa e um corpo com menos massa, vão ter efeitos diferentes justamente por causa da sua massa. O que mais que a gente viu? A gente viu que a essa massa e a essa velocidade, eu vou associar uma grandeza física chamada quantidade de movimento que eu vou multiplicar simplesmente a massa vezes a sua velocidade. Com isso aí a gente vai dar um passo a frente agora e vamos tentar entender algumas situações que acontecem constantemente no nosso cotidiano. Como vocês podem ver (...) ele faz uma abordagem dizendo que na verdade não pode pensar em movimento somente de um corpo, sempre tem que pensar em movimento onde aja a interação entre dois corpos. Então, assim, quando eu produzo o movimento, eu vou ter duas situações, ou esse corpo vai andar sozinho, ou esse corpo vai interagir com o outro corpo. Vocês sabem me dizer algum movimento de um corpo que anda sozinho, sem interagir com outro corpo? Saberiam me dizer um movimento desse jeito? (ninguém se manifesta). Agora vamos pensar ao contrário, um movimento de um corpo que interage com outro corpo, dois corpos. Deem um exemplo de movimento!

$<0: 11: 22>$ A(aleatório): Arco e flecha.

$<0: 11: 23>$ P: Arco e flecha, que mais? Leiam o exemplo que vocês colocaram aí, gente! O caminhar, não tem interação entre dois corpos? O seu corpo com a Terra?

$<0: 11: 37>$ A(aleatório): Professor, professor! O barco!

$<0: 11: 38>$ P: O barco! O barco tá interagindo com o que? O barco com a água! Que mais? A moto com a terra! Então, se tu começar a analisar, vai ver que não existe quase na natureza como tu observar o movimento de um corpo sem ter a interação de outro corpo. Sempre vai ter a interação entre dois corpos. Sempre, alguns tipos de movimento que a gente vai ver mais pra frente que vai ter a interação de um único corpo, e vai cair nessa lei de conservação de quantidade de movimento que a gente vai ver. Que que quer 
dizer essa lei ali, gente? (se referindo ao quadro). Que que é uma lei?

$<0: 12: 26>\mathrm{A}($ aleatório): É uma regra!

$<0: 12: 27>$ P: Uma regra para ser seguida, que não pode ser quebrada. Vamos lá, me dêem um exemplo.

$<0: 12: 33>\mathrm{A}$ (aleatório): $\mathrm{O}$ uso do celular!

$<0: 12: 34>$ P: O uso do celular, não pode, é uma lei que diz que tu não pode usar o celular, então assim, uma lei em ciência, em Física, ela é como se fosse uma regra, e ela tem dois pontos a destacar, o primeiro é que tu tem que seguir essa regra, e a segunda é que tu não pode violar essa regra, essa regra é inviolável. Então, essa lei da conservação do movimento, ela diz o seguinte, que quando você tiver a interação entre dois corpos, na realidade, a colisão entre dois corpos, o choque entre dois corpos, então esse movimento, uma vez que existe, ele vai ser conservado pro resto da vida. É dificil a gente tentar interpretar isso? É! Mas por incrível que pareça, quando você está caminhando, a tua quantidade de movimento, vai ser transferida para a Terra. Mas tu ver a terra se mover? Não, né? Mas ela se move, só que ela se move muito pouco por quê? $\mathrm{O}$ que influencia a gente em não enxergar o movimento da Terra?

$<0: 14: 12>$ A(aleatório): O tamanho dela?

$<0: 14: 15>$ P: Pensem no pêndulo pequeno e no pêndulo grande.

$<0: 14: 18>$ A(aleatório): A massa.

$<0: 14: 18>$ P: A massa. Se eu fazer esse movimento de pular aqui (professor pula), a pergunta é eu estou interagindo com outro corpo? A pergunta é: eu empurro a terra ou não empurro?

$<0: 15: 04>$ Alunos: Empurra.

$<0: 15: 06>\mathrm{P}$ : Eu vou empurrar, porque essa lei também quer dizer o seguinte: que o movimento é uma coisa que nunca cessa. A lei diz que o movimento se conserva e essa conservarção quer dizer o seguinte: que eu transfiro de um corpo para o outro. Sempre eu vou transferir de um corpo para o outro. Então eu vou tentar mostrar isso pra vocês aqui, uma coisa bem simples, para vocês entenderem, que é o seguinte: como nós vamos encarar a parte matemática disso aqui? Então primeiro eu vou dar um exemplo que não é quantitativo ainda de números, mas ele já dá pra fazer a análise que é o seguinte: eu sempre vou ter que separar meu problema num antes e num depois. (professor pede que alguns alunos troquem de lugar, pois não enxergarão o que está explicando no quadro se continuarem naqueles lugares). Só olhem, eu vou ter um antes e tenho que ter um depois, imagina quando uma mulher vai num salão de beleza, ela tem o antes e ela tem o depois. O antes, eu vou hipotetizar uma situação do antes, só que o depois são praticamente infinitas possibilidades de como a mulher vai sair de lá de dentro. Ela pode sair de cabelo amarelo, cabelo azul, com as unhas feitas, fazer chapinha, ou seja, são infinitas possibilidades que podem ocorrer depois que ela tá lá dentro. Então, seguinte, nessa colisão que eu estou propondo para vocês aqui, entre dois corpos, com uma interação entre os corpos, eu vou colocar três possibilidades, mas eu estou afirmando para vocês que aqui poderia aparecer infinitas possibilidades do que ocorre depois, então eu estou hipotetizando aqui situações prováveis. Então é o seguinte, essa bolinha Bestá parada, então a velocidade dela é zero, se a velocidade é zero, a quantidade de movimento dela também vai ser?

$<0: 17: 51>$ Alunos: Zero!

$<0: 17: 52>$ P: Então eu terei: quantidade de movimento da bolinha B: zero. Já a minha bolinha $\mathrm{A}$, ela estará se movimentando com uma determinada velocidade que não vem ao caso aqui, e eu associei a esse movimento aqui uma quantidade de movimento que eu dei o valor de: $40 \mathrm{~kg} . \mathrm{m} / \mathrm{s}$. Então eu vou hipotetizar a primeira situação aqui: a primeira situação tá dizendo o seguinte: que a bolinha $\mathrm{A}$ bate na bolinha $\mathrm{B}$, mas a 
bolinha A permanece parada, só quem anda é a bolinha B. Se a minha bolinha A permaneceu parada, quer dizer que a minha bolinha B vai ter que se movimentar, e a pergunta é a seguinte: quanto é a quantidade de movimento desse lado aqui? (indica o quadro negro, na parte do 'depois'). E gente, temos que pensar assim: se conservar o movimento é transferir,

e dividir, vocês não concordam que eu transferi essa quantidade de movimento (indica o antes no quadro) lá pro depois? Transferi ou não?

$<0$ :19:08> Alunos: Sim!

$<0: 19: 09>$ P: então, se tu pegar e somar a quantidade de movimento dos dois corpos do exemplo, $40+0$ vai dar quanto?

$<0$ :19:25> Alunos: 40!

$<0: 19: 26>$ P: 40 ! quer dizer que se desse lado deu 40, do outro lado também sempre vai ter que dar?

$<0: 19: 31>$ Alunos: 40 !

$<0: 19: 32>$ P: 40, beleza? Isso é conservar! Eu tenho 40 desse lado aqui, eu vou passar 40 lá pro outro lado.

$<0$ :19:41> Aluna: Aí esse lado aqui perde o 40?

$<0: 19: 45>$ P: Não é que ele perde, quando eu estou trabalhando com esse lado, eu tenho os dois corpos, que é a minha situação inicial, lá eu tenho uma situação que ocorre depois da colisão. Então vejam bem, aqui deu 40, lá sempre vai ter que dar quanto? 40! Se aqui é zero, quanto vai ser o B? (professor aponta para a fase final da situação).

$<0: 20: 09>$ Alunos: Zero.

$<0: 20: 12>$ P: 40!!! Concordam com isso ou não? Se a soma desse lado (inicial) é 40, do outro lado tem que ser o que? 40! Isso é uma possibilidade, eu estou hipotetizando, ok? Vamos para uma segunda possibilidade aqui: eu bati nessa aqui, mas eu não fiquei parado, eu continuei andando pra frente, com uma quantidade de movimento 10, quanto que vai ter que ser a quantidade de movimento lá?

$<0: 20: 50>$ Alunos: 10 !

$<0: 20: 55>$ P: (professor escreve no quadro '10'), por quê? $30+10$ é? 40! Uma terceira possibilidade é: eu choco uma com a outra, a B vai pra frente e a A retorna, retorna com uma quantidade de movimento igual a quanto? 15! Quanto é a quantidade de movimento lá?

$<0: 21: 20>$ Alunos: 55. 25. 30 .

$<0: 21: 32>$ P: 55 ? Como? Pensem comigo aqui: tu não pode ter a mais, não serve. Então se tu transferiu, tem que transferir o mesmo, e lá do outro lado tu vai acabar dividindo, dependendo das condições que tu tem. Se a massa é maior, se a massa é menor, o tipo de choque, então, jamais vai poder passar a soma desse aqui de quanto? Se aqui é 15, quanto vai ser a outra?

$<0: 22: 09>$ Aluna: Mas não interfere se ela foi pra trás ou pra frente?

$<0: 22: 10>$ P: A soma tem que dar quanto?

$<0: 22: 15>$ Alunos: 40, 25, 55.

$<0: 22: 24>$ P: Vamos no popular, você gosta de jogar futebol, beleza? Então quando tu bate na perna, tu transfere o que para a bola?

$<0: 22: 30>$ Alunos: Força.

$<0: 22: 33>$ P: Não, quantidade de movimento. Se tu tivesse que calcular a quantidade de movimento que tu transfere para a bola, tu ia pegar, descobrir a massa da tua perna, a velocidade da tua perna, e tu ia bater, daí a pergunta é a seguinte: transferiu quantidade de movimento para a bola, concorda? Agora, tu transferiu toda a quantidade de movimento da tua perna para a bola? Só se tu hipotetizar, certo? Tu garante que tu bate a tua perna na bola e tua perna fica parada e a bola vai? Esse é um ponto de vista, o 
outro: se a quantidade de movimento da tua perna é 100, qual é o máximo que tu vai conseguir transferir pra bola?

$<0: 23: 22>$ Alunos: 100 .

$<0: 23: 23>$ P: 100 ! aqui não tem como tu transferir mais (indicando os casos anteriores), mas esse aqui tá apontando pra cá, não tem problema, é uma soma líquida que você tem que ter, essa soma aqui não vai poder ultrapassar, porque se tu ultrapassar, tu vai estar violando a lei, tu vai estar quebrando uma regra. Então a gente vai ver umas situações, nas próximas aulas, você vai ver algumas situações, colocadas em filmes e histórias em quadrinho que você vai ver que viola essa lei. Alguma dúvida, pergunta? Tranquilo? Só pra encerrar, vamos pegar um exemplo dele aqui, diz o primeiro exemplo que tu colocou no teu trabalho.

$<0: 24: 51>$ Aluno: o barco quando nós vamos remar, quando a gente puxa o remo, o barco se move.

$<0: 25: 00>$ P: Então vamos entender isso aí, vamos supor então que tu pega o remo e empurra o remo pra trás. Tu vai pra frente, a pergunta é: a quantidade de movimento que tu tinha no remo.

(aula interrompida)

$<0: 27: 08>$ P: Pessoal, voltando ao exemplo, então eu empurro o remo, vocês concordam que houve uma interação entre o remo e a água?

$<0: 27: 13>$ Alunos: Sim.

$<0: 27: 14>$ P: São ou não são dois corpos? Um é a água e o outro é o remo, a água está parada e o remo tu vai aplicar uma velocidade, então a quantidade de movimento do remo vai ser transferida pra água? Se a quantidade de movimento do remo é 100, depois que houver a colisão, a quantidade de movimento do remo não é transferida pra água? Só pra finalizar esse exemplo aqui pra gente fazer outra atividade...

$<0: 28$ :10> Aluna: Professor, rapidinho, e quando é em relação tipo ao que eu coloquei, tipo o arco e a flecha, daí a interação é com o ar?

$<0: 28: 17>$ P: A tua interação vai ser entre a flecha e a corda, entendeu? Quem vai produzir a velocidade?

$<0: 28: 28>$ Alunos: A corda.

$<0: 28: 29>$ P: E vai transferir pra quem?

$<0: 28: 30>$ Alunos: Para a flecha.

$<0: 28: 32>\mathrm{P}$ : Como que vocês podem imaginar que isso aí tá relacionado ao movimento de um corpo, depois a gente vai ver lá, a gente vai entrar nas leis de Newton, que depende disso aqui, tá? Na primeira lei de Newton a gente vai chegar nisso aí, tá? O que eu quero que vocês entendam é que nessas situações aqui, tem muito mais situações, certo? Por exemplo, poderia dizer que essa bola fica parada e que essa aqui retorna, então são infinitas possibilidades aqui, o que eu quero que vocês saibam é que quando você tiver um problema desse aqui tu não pode agir no instinto e dizer 'não, vai pra direita, vai pra esquerda', tu vai ter que pensar e dizer o seguinte "depende das condições que eu criar, depende das minhas hipóteses", então eu coloquei três hipóteses aqui, a pergunta é a seguinte: em alguma dessas três hipóteses a quantidade de movimento foi transferida totalmente de um corpo para o outro?

$<0: 30: 14>$ Alunos: No exemplo 1

$<0: 30: 16>$ P: Na primeira, não é? Mas quer dizer que sempre vai ser assim?

$<0: 30: 19>$ Alunos: Não.

$<0: 30: 20>$ P: Vai depender da possibilidade que você colocou, segunda pergunta: a quantidade de movimento se conservou aqui? (indicando os três casos)

$<0: 30: 33>$ Alunos: Sim, sim, sim.

$<0: 30: 34>$ P: Sempre vai se conservar, porque eu não posso violar isso aqui (se refere à 
lei de conservação). Vamos, deixa eu ver se tem mais alguma coisa aqui, eu acho que é isso.

(tempo para que os alunos copiem o assunto do quadro)

$<0: 31: 29>$ A5: Professor, professor!

(professor nos outros grupos)

$<0: 32: 08>$ A5: Vou perguntar pro professor se o do avião está certo. Professor! Vem aqui um pouquinho?!

(professor não vai)

$<0: 32: 35>$ P: Pessoal, atenção, vamos fazer a terceira atividade que tá na folhinha, que é a atividade dos problemas abertos, ok?

$<0: 32: 55>$ A5: Professor! Ali eu pensei num avião de hélice, a hélice empurra o vento pra trás e vai pra frente, tá certo?

$<0: 33: 10>$ P: Tá.

$<0: 33: 11>$ A5: Viu, A1?

(professor se aproxima do grupo)

$<0: 33: 25>$ P: A5, isso que tu tá pensando, um corpo é o ar, o outro corpo é a hélice, certo?

$<0: 33: 35>$ A5: Ela vira, empurra o ar pra trás e voa pra frente.

(professor retorna a frente da sala)

$<0: 33: 41>$ P: Pessoal, a atividade que está proposta aí são problemas abertos, certo? Então, eu trabalhei com vocês a técnica de problema aberto, seguindo aqueles 5 passos, análise, hipótese, elaboração de estratégia, aplicação da estratégia e a conclusão, ok? Então a proposta colocada aí no problema aberto, vocês podem aplicar dentro dessas 5 situações, então vocês tem 20 min pra resolver essas questões que estão aí, mas é simples, a análise do problema, o que é? Eu preciso descobrir tal coisa, hipóteses, o que você vai hipotetizar, ah, velocidade é tanto, tanto e tanto, o choque vai ter aqui, um vai ficar parado, beleza? Então, rápido, discutam com o grupo, 20 minutinhos pra pensar. $<0: 35: 00>$ A5: Tá, o que precisa, a massa...

\section{Episódio 2 - Problemas abertos (atividade 3 da SEI)}

\begin{tabular}{|c|c|c|}
\hline $\begin{array}{c}\text { Tempo } \\
\text { inicial e final } \\
\text { da cena }\end{array}$ & Transcrição, Descrição das ações e linguagens & Ciclo Argumentativo \\
\hline \multirow[t]{3}{*}{$\begin{array}{c}00: 35: 10- \\
00: 36: 10\end{array}$} & \multirow{3}{*}{$\begin{array}{l}\text { A6: A letra 1, qual a máxima quantidade de movimento você } \\
\text { consegue transferir a uma bola durante pênalti? } \\
\text { A5: Precisamos determinar. } \\
\text { A2: Como é que é isso aí. } \\
\text { A5: A força? /// A2: isso eu entendo... isso eu entendo... qual a } \\
\text { máxima quantidade de movimento. } \\
\text { A5: Qual a máxima quantidade de movimento você consegue } \\
\text { transferir a uma bola durante pênalti? } \\
\text { A2: Qual é a máxima. } \\
\text { A5: Máxima quantidade de movimento dela... } \\
\text { A2: Qual é a máxima? } \\
\text { A5: Uns } 80 \mathrm{~km} / \mathrm{h} \text { ? } \\
\text { A2: A máxima quantidade de movimento depende da força } \\
\text { que tu usar... } \\
\text { A5: Então, nós temos que descobrir... precisamos descobrir a }\end{array}$} & Cuidado com os dados \\
\hline & & Argumentação \\
\hline & & \\
\hline
\end{tabular}




\begin{tabular}{|c|c|c|}
\hline & $\begin{array}{l}\text { força do:: choque... é né? } \\
\text { A5: ALUNO } 1 . \\
\text { A1: É uma possibilidade de hipótese... né? }\end{array}$ & \\
\hline $\begin{array}{c}\text { Tempo } \\
\text { inicial e final } \\
\text { da cena } \\
\end{array}$ & Transcrição, Descrição das ações e linguagens & Ciclo Argumentativo \\
\hline \multirow[t]{3}{*}{$\begin{array}{c}00: 36: 20- \\
00: 36: 40\end{array}$} & \multirow{3}{*}{$\begin{array}{l}\text { A5: Vou chamar o professor... oh PROFESSOR! Aqui, aqui } \\
\text { eu preciso descobrir a quantidade da força que vai chutar ela? } \\
\text { P: Que é força? } \\
\text { A5: Que tu vai chutar a bola! } \\
\text { P: O que ele tá perguntando? } \\
\text { A5: A máxima quantidade de movimento... tá... digamos que... } \\
\text { P: E como tu descobre a quantidade de movimento? }\end{array}$} & Cuidado com os dados \\
\hline & & Argumentação \\
\hline & & $\begin{array}{l}\text { Seriação } \\
\text { Hipótese }\end{array}$ \\
\hline $\begin{array}{c}\text { Tempo } \\
\text { inicial e final } \\
\text { da cena } \\
\end{array}$ & Transcrição, Descrição das ações e linguagens & Ciclo Argumentativo \\
\hline \multirow[t]{3}{*}{$\begin{array}{c}00: 36: 40- \\
00: 37: 30\end{array}$} & \multirow{3}{*}{$\begin{array}{l}\text { A5: Faz a massa vezes a velocidade... então... tem que fazer a } \\
\text { análise lá... } \\
\text { A1: Possibilidades... } \\
\text { A6: Hipotetizando. } \\
\text { A2: Tá mas a gente não tem um valor. } \\
\text { A6: Por isso tem que descobrir... tem que fazer aquelas... } \\
\text { A5: Não por isso tem que fazer aquela.... descobrir lá... } \\
\text { A2: A análise... } \\
\text { A5: A análise... } \\
\text { A6: Eu tenho tudo aquilo que ele passou... ((se referindo aos } \\
\text { passos de resolução dos problemas abertos passados pelo } \\
\text { professor)). } \\
\text { A5: Então... olha aí e ajuda a fazer isso. } \\
\text { A6: Não eu não vou ajudar ((sorri)) } \\
\text { A5: Não é fácil esse grupo cara... é eu e o A2 só... } \\
\text { A6: O A2 é um burro e não faz nada... óh... velocidade } \\
\text { média:.... } \\
\text { A5: Hã? } \\
\text { A6: Velocidade média... }\end{array}$} & Cuidado com os dados \\
\hline & & Argumentação \\
\hline & & Seriação \\
\hline $\begin{array}{c}\text { Tempo } \\
\text { inicial e final } \\
\text { da cena }\end{array}$ & Transcrição, Descrição das ações e linguagens & Ciclo Argumentativo \\
\hline \multirow[t]{3}{*}{$\begin{array}{c}00: 37: 30- \\
00: 38: 30\end{array}$} & \multirow{3}{*}{$\begin{array}{l}\text { A6: O que é "MV"? } \\
\text { A1: Como é que é? /// A2: Velocidade média? } \\
\text { A6: MV? } \\
\text { A1: M o quê? /// A6: Não ((respondendo a A2)). } \\
\text { A5: Não sei, tu que tem que ver... tu que escreveu... } \\
\text { A6: Você que escreveu no meu caderno... O PROFESSOR... } \\
\text { /// A5: Ele explicou aquele dia... } \\
\text { A6: PROFESSOR... professor... professor qual é o significado } \\
\text { do "MV"? Qual é o significado do "MV"? /// A5: } \\
\text { Movimento? } \\
\text { A6: Movimento? } \\
\text { P: Movimento variável... /// A5: Olha ali óh... massa... } \\
\text { ((aponta para a lousa e depois olha para o caderno)) } \\
\text { P: Isso aqui não tem nada a ver com o problema. /// A5: Olha } \\
\text { ali o A6... o A6? } \\
\text { A6: A gente vai ter que a:.... } \\
\text { P: a hipótese? } \\
\text { A6: É. } \\
\text { P: A hipótese vocês vão ter que chutar valores cara. } \\
\text { A2: Então é:.....valores imaginários... né? } \\
\text { A5: É:: } \\
\text { P: Pra calcular a quantidade de movimento precisa saber o }\end{array}$} & Cuidado com os dados \\
\hline & & Argumentação \\
\hline & & $\begin{array}{c}\text { Seriação } \\
\text { Classificação e } \\
\text { organização dos dados }\end{array}$ \\
\hline
\end{tabular}




\begin{tabular}{|c|c|c|}
\hline & $\begin{array}{l}\text { que? } \\
\text { A2: A massa... /// P: A massa e a? } \\
\text { A5 e A6: Velocidade. } \\
\text { P: Mas qual é a quantidade máxim/... tu só vai poder } \\
\text { determinar isso se determinar antes o quê? A massa e a? /// } \\
\text { A5 : Ah:: } \\
\text { A6: Velocidade. } \\
\text { P: Então tu vai ter que hipotetizar. }\end{array}$ & \\
\hline $\begin{array}{c}\text { Tempo } \\
\text { inicial e final } \\
\text { da cena }\end{array}$ & Transcrição, Descrição das ações e linguagens & Ciclo Argumentativo \\
\hline \multirow[t]{3}{*}{$\begin{array}{c}00: 38: 30- \\
00: 39: 00\end{array}$} & \multirow{3}{*}{$\begin{array}{l}\text { A2: Então é um valor... } \\
\text { A5: Qual vai ser... qual vai ser a quantidade de massa? } \\
\text { A2: Um valor imaginário...1100... quilos. } \\
\text { A6: Tá sem chutinho o menino... ((Alunos riem da estimativa } \\
\text { absurda)) } \\
\text { A6: ((inaudível)) ... através da rede. } \\
\text { A2: Chuta isso e o pé fica na bola... } \\
\text { A5: Pega pega fogo tá ligado... } \\
\text { A2: Então deve ser o que? Uns... } 2 \mathrm{~kg} \text { né? Dois quilos mais ou } \\
\text { menos... ((A5 e A6 não prestam a atenção e começam a } \\
\text { conversar entre si em tom de brincadeira e A5 retoma o foco, } \\
\text { então A2 volta-se para A3 e A1 e inicia uma discussão)) /// } \\
\text { A5: Presta atenção cara... na moral... por favor cara... } \\
\text { A3: Dois o quê? } \\
\text { A2: A bola vai ter uns dois quilos né? } \\
\text { A1: Ah claro ((em tom irônico)). } \\
\text { A3: Não. } \\
\text { A1: Nem no escuro velho. /// A6 ((falando para A5)): Tá... } \\
\text { suponhamos que ele deu um chute na bola.... } \\
\text { A3: Depende... ((inaudível)) }\end{array}$} & Cuidado com os dados \\
\hline & & Argumentação \\
\hline & & $\begin{array}{c}\text { Seriação } \\
\text { Classificação e } \\
\text { organização dos dados }\end{array}$ \\
\hline $\begin{array}{c}\text { Tempo } \\
\text { inicial e final } \\
\text { da cena }\end{array}$ & Transcrição, Descrição das ações e linguagens & Ciclo Argumentativo \\
\hline \multirow[t]{3}{*}{$\begin{array}{c}00: 39: 00- \\
00: 39: 45\end{array}$} & \multirow{3}{*}{$\begin{array}{l}\text { A2: a bola de futebol de campo é pesadinha. } \\
\text { A5: Ôh como é que vai ficar aí? } \\
\text { A3: Então... que... /// A1: Não... não chega a ter dois quilos. } \\
\text { A6: ÔH você não entende de futebol... você só ajuda a fazer... } \\
\text { você não entende de jogo ((A5 cutuca o braço de A6 e olha } \\
\text { com desaprovação)). } \\
\text { A3: Então vai ((xinga))... beleza... não vou falar mais nada.... } \\
\text { façam sozinhos aí. } \\
\text { A5 ((para A6)): não faz essas coisas velho. } \\
\text { A6: Eu não óh... } \\
\text { A2: Deve ter um quilo eu acho. } \\
\text { A1: Um quilo... (nem) ((acena negativamente com a cabeça)). } \\
\text { A5: Não... a massa...a massa... o 'MV' Aluno } 6 . . . \text { é só tu olhar } \\
\text { no quadro... massa vezes a velocidade... né? E vai ser/ e o Q é } \\
\text { a quanti/. ... tá... qual vai ser a massa? } \\
\text { A5: Pô... Assim não dá... vou falar para o professor que eu não } \\
\text { quero mais fazer isso... } \\
\text { A2: Eu também não quero... O professor fica filmando a } \\
\text { gente. }\end{array}$} & $\begin{array}{l}\text { Cuidado com os dados } \\
\text { Definição das } \\
\text { variáveis relevantes ao } \\
\text { problema }\end{array}$ \\
\hline & & Argumentação \\
\hline & & $\begin{array}{c}\text { Seriação } \\
\text { Classificação e } \\
\text { organização dos dados } \\
\text { Justificativa }\end{array}$ \\
\hline $\begin{array}{l}\text { Tempo inicial } \\
\text { e final da cena }\end{array}$ & Transcrição, Descrição das ações e linguagens & Ciclo Argumentativo \\
\hline
\end{tabular}




\begin{tabular}{|c|c|c|}
\hline \multirow[t]{3}{*}{$\begin{array}{c}00: 39: 45- \\
00: 40: 30\end{array}$} & \multirow{3}{*}{$\begin{array}{l}\text { A5: Qual vai ser a massa? } \\
\text { A2: Um quilo. } \\
\text { A1: Quantos quilos? Quantos quilos? } \\
\text { A6: Não... não... a bola não tem um quilo... tem dois. } \\
\text { A5: Ah tá ((desdenhando)). } \\
\text { A2: Eu falei dois... eles falaram que era impossível. } \\
\text { A6: Não... tem mais. } \\
\text { A5: Não... não... a bola não tem dois quilos ((balança a } \\
\text { cabeça negativamente)). } \\
\text { A1: Não chega a ter dois quilos. } \\
\text { A5: Não. } \\
\text { A3 ((para A1)): Não tem... a gente fez um trabalho... não } \\
\text { tem dois quilos ((inaudível)). /// A2: Tem... a de futebol de } \\
\text { campo tem. } \\
\text { A6: A de dois quilos tem dois quilos ((se referindo à bola de } \\
\text { campo)). } \\
\text { A5: Ela é levinha para caramba. } \\
\text { A6: A de campo tem dois quilos sossegada. } \\
\text { A2: Vai... joga dois quilos aí. } \\
\text { A5: Dois quilos tem a de quadra... dois quilo tem... a bola de } \\
\text { quadra é mais pesada e tem dois quilos. } \\
\text { A2: Cala a boca a bola é mais pesada ((de campo)). } \\
\text { A6: A de quadra é mais pesada do que a de campo. } \\
\text { A5: Dois quilos tem a bola de quadra. /// A3 ((falando para } \\
\text { A1 e rindo)): É de cimento. } \\
\text { A6: Não a de campo tem dois quilos... pode colocar ali. /// } \\
\text { A1: Há? I// A3: É de cimento. } \\
\text { A5: Vamos colocar um quilo e meio então. } \\
\text { A6: Não dois quilos. } \\
\text { A5: UM QUILO E MEIO. }\end{array}$} & $\begin{array}{l}\text { Cuidado com os dados } \\
\text { Definição das } \\
\text { variáveis relevantes ao } \\
\text { problema }\end{array}$ \\
\hline & & Argumentação \\
\hline & & $\begin{array}{c}\text { Seriação } \\
\text { Classificação e } \\
\text { organização dos dados } \\
\text { Justificativa }\end{array}$ \\
\hline $\begin{array}{l}\text { Tempo inicial } \\
\text { e final da cena }\end{array}$ & Transcrição, Descrição das ações e linguagens & Ciclo Argumentativo \\
\hline \multirow[t]{4}{*}{$\begin{array}{l}00: 40: 30 \\
00: 41: 30\end{array}$} & \multirow{3}{*}{$\begin{array}{l}\text { A6: EI o professor falou que tem que ser redondo... para ser } \\
\text { mais fácil de... /// A5: Então faz cinco ((ri de A6)). } \\
\text { A6: Cala a boca... eu vou colocar dois quilos... porque tem } \\
\text { que fazer do seu jeito. } \\
\text { A2: Faz dois cara. } \\
\text { A5: Tá bom... tá... a dois... ele vai ficar o que aí. } \\
\text { A1: Bora fazer uma peca de cimento aí. } \\
\text { A2: Oitenta por hora... a velocidade normalmente é. } \\
\text { A6: NÃO:: cara } \\
\text { A5: A velocidade no chute... não/a bola. } \\
\text { A6: A do chute? /// A5: Nós temos que descobrir.:.: } \\
\text { A6: Não... nós temos que hipotetizar. } \\
\text { A5: Daí nós temos que ter dois números... daí depois vai ter } \\
\text { que mudar ali ((aponta para lousa))... para estar div/tá } \\
\text { multiplicando passa div/vai trocar o Q. } \\
\text { A6: Tá. } \\
\text { A5: Ah aquela ali não faz nada... não ajuda nada ((sobre a } \\
\text { aluna 3)). } \\
\text { A3: Eu fui falar e esse aqui ficou enchendo o saco... então eu } \\
\text { não vou falar ((xingamento))... I// A5: Você não pode levar } \\
\text { esse cara a sério o que o aluno } 6 \text { fala. } \\
\text { A1: Quer uma dica? Ignora. } \\
\text { A5: Como é que uma namorada vai ignorar o seu namorado } \\
\text { ((brincando)). } \\
\text { A1 ((falando para A3)): É... esquece.... esquece. } \\
\text { A5: Vai vamos fazer ((inaudível)). } \\
\text { A3: Para de falar ((inaudível)) que está filmando. }\end{array}$} & $\begin{array}{c}\text { Cuidado com os dados } \\
\text { Definição das } \\
\text { variáveis relevantes ao } \\
\text { problema } \\
\end{array}$ \\
\hline & & Argumentação \\
\hline & & $\begin{array}{c}\text { Seriação } \\
\text { Classificação e } \\
\text { organização dos dados } \\
\text { Justificativa } \\
\text { Dedução }\end{array}$ \\
\hline & Transcrição, Descrição das ações e linguagens & Ciclo Argun \\
\hline
\end{tabular}




\begin{tabular}{|c|c|c|}
\hline e final da cena & & \\
\hline \multirow[t]{3}{*}{$\begin{array}{c}00: 41: 30 \text { - } \\
00: 42: 30\end{array}$} & \multirow{3}{*}{$\begin{array}{l}\text { P ((falando para toda a sala)): PESSOAL SUGESTÃO... } \\
\text { primeira questão é isso aqui ((aponta esquema }{ }^{37} \text { no quadro } \\
\text { no qual há o choque de dois objetos))... não é nada diferente } \\
\text { disso aqui... a única coisa que você vai ter que:: hipotetizar é } \\
\text { o valor de:: massa da bola e velocidade da bola. } \\
\text { A5: Ah então... o 'A' vai ser a perna do carinha... que está } \\
\text { parado... } \\
\text { A2: A bo/o 'A' está parado. /// A5: a não o 'B' está parado. } \\
\text { A2: O B é a bola. /// A5: O B é a bola... certão. } \\
\text { A2: E o 'A' é a perna. } \\
\text { A5: Aí só vai inverter o:..... qual que está em movimento? O } \\
\text { B né? } \\
\text { A2: Não cara é o A. /// A1: O A. } \\
\text { A5: Então o A vai ser a perna/que eu falei. } \\
\text { A2: Tu falou que a::: per/a:: bola /// A5: A PERNA. } \\
\text { A6: Tu falou a bola a bola. } \\
\text { A1: Tu falou que a bola ia ser o movimento. } \\
\text { A5: Sim ela ia se movimentar... } \\
\text { A2: Não.. } \\
\text { A5: Ia... ia. } \\
\text { A2: Não. Estou com vontade de comer ((inaudível)). } \\
\text { A1: TÁ... esquece } \\
\text { A2: Sem zueira... deu uma vontade agora... estou quebrado. }\end{array}$} & $\begin{array}{c}\text { Cuidado com os dados } \\
\text { Definição das } \\
\text { variáveis relevantes ao } \\
\text { problema } \\
\end{array}$ \\
\hline & & Argumentação \\
\hline & & $\begin{array}{c}\text { Seriação } \\
\text { Classificação e } \\
\text { organizaçãa dos dados }\end{array}$ \\
\hline $\begin{array}{c}\text { Tempo } \\
\text { inicial e final } \\
\text { da cena }\end{array}$ & Transcrição, Descrição das ações e linguagens & Ciclo Argumentativo \\
\hline \multirow[t]{3}{*}{$\begin{array}{l}00: 42: 30- \\
00: 43: 20\end{array}$} & \multirow{3}{*}{$\begin{array}{l}\text { A5: Tá... éh.:. e tá... E que velocidade que a perna vai ir? Já } \\
\text { descobriram já? } \\
\text { A2: Oitenta. } \\
\text { A6: Sessenta sessenta. } \\
\text { A2: Pra mim é chute... cara. } \\
\text { A5: TÁ... mas quanto colocar? Colocar quanto então? } \\
\text { A6: Sessenta. } \\
\text { A1: Oitenta. } \\
\text { A2: Oh sessenta meu irmão de dez ((anos)). /// A1: Oitenta. } \\
\text { A5: Éh:: tá oitenta oitenta. } \\
\text { A6: Tá tu acha que tu vai pegar oitenta quilômetros por hora? } \\
\text { A5: Claro que pega aluno } 6 \ldots \text { não parece porque a distância é } \\
\text { curta... mas da um ((chute)) com força/pega aquele/aquelas } \\
\text { bagaça e coloca na tua perna pra ver... a velocidade do chute... } \\
\text { dá para fazer/ dá para fazer. /// A2: Eu acho que chega... até } \\
\text { oitenta. } \\
\text { A5: Claro que chega a oitenta. } \\
\text { A2: Eu acho que chega. } \\
\text { A5: Se a bola chega a oitenta por hora... a velocidade... do } \\
\text { chute na hora de chutar tem que ser pelo menos a:.... pelo } \\
\text { menos não... tem que ser mais da metade do do... da } \\
\text { velocidade da bola... oitenta dá. } \\
\text { A6: Então vai... } \\
\text { A5: O cara chuta... o cara chutou a bola de um quilo a oitenta } \\
\text { por hora. } \\
\text { A6: De dois quilos. } \\
\text { A5: Dois quilos é... certo. } \\
\text { A2: A oitenta por hora. }\end{array}$} & $\begin{array}{l}\text { Cuidado com os dados } \\
\text { Definição das } \\
\text { variáveis relevantes ao } \\
\text { problema } \\
\end{array}$ \\
\hline & & Argumentação \\
\hline & & $\begin{array}{c}\text { Seriação } \\
\text { Classificação e } \\
\text { organização dos dados } \\
\text { Justificativa } \\
\text { Previsão } \\
\text { Raciocínio Lógico e } \\
\text { Proporcional }\end{array}$ \\
\hline
\end{tabular}

\footnotetext{
${ }^{37}$ No exemplo no quadro, uma bola choca-se com outra e são sugeridas e calculadas três opções de conservação: 1- toda a quantidade de movimento da primeira bola é transferida para a segunda; 2 e 3 - a quantidade de movimento da primeira e transferida parcialmente para a segunda.
} 


\begin{tabular}{|c|c|c|c|}
\hline $\begin{array}{l}\text { Tempo inicial } \\
\text { e final da cena }\end{array}$ & & Transcrição, Descrição das ações e linguagens & Ciclo Argumentativo \\
\hline \multirow{3}{*}{$\begin{array}{c}00: 43: 20- \\
00: 43: 40\end{array}$} & \multirow{3}{*}{\multicolumn{2}{|c|}{$\begin{array}{l}\text { A6: Tá agora divide por... } \\
\text { A5: Quarenta. } \\
\text { A6: Quarenta. } \\
\text { A2: Tá e (o que que é quarenta)? } \\
\text { A6: AH::: ai vai dar um mesmo bagulho louco... se nós fizer } \\
\text { vai dar o mesmo troço lá óh ((aponta para a lousa)). } \\
\text { A5: A resposta é vinte e cinco professor ((alunos em tom de } \\
\text { brincadeira consideram os cálculos que estão na lousa, da } \\
\text { forma como estão, no problema que estão resolvendo)). } \\
\text { A2: Já está tudo feito. } \\
\text { A1: Vinte e cinco? } \\
\text { A6: O professor. } \\
\text { A5: Olha lá... o resultado é vinte e cinco... olha lá. } \\
\text { A1: Não era quarenta? }\end{array}$}} & $\begin{array}{c}\text { Definição das } \\
\text { variáveis relevantes ao } \\
\text { problema }\end{array}$ \\
\hline & & & Argumentação \\
\hline & & & $\begin{array}{c}\text { Classificação e } \\
\text { organização dos dados } \\
\text { Abdução } \\
\text { Dedução }\end{array}$ \\
\hline $\begin{array}{c}\text { Tempo } \\
\text { inicial e final } \\
\text { da cena } \\
\end{array}$ & & Transcrição, Descrição das ações e linguagens & Ciclo Argumentativo \\
\hline \multirow[t]{3}{*}{$\begin{array}{c}00: 43: 40- \\
00: 44: 30\end{array}$} & \multirow{3}{*}{\multicolumn{2}{|c|}{$\begin{array}{l}\text { A6: ÔH PROFESSOR. } \\
\text { P: Oi. } \\
\text { A6: Óh... suponhamos que a bola tem } 2 \text { quilos e a pressão do } \\
\text { chute vai dar } 80 \text { quilômetros por hora... daí divide o } \\
\text { ((inaudível)) vezes... daí divide e dá } 40 . \\
\text { P: Primeiro... a velocidade tem que ser em metros por } \\
\text { segundo. } \\
\text { A5: AH.: é oitenta metros por segundo. /// P: É oitenta metros } \\
\text { por segundo. } \\
\text { A6: É oitenta metros por segundo. } \\
\text { P: Bicho... /// A5: Tá... é muito. } \\
\text { P: A oitenta quilômetros por hora. } \\
\text { A6: Eu falei para vocês ((inaudível, pois A5 e A6 falam algo } \\
\text { ao mesmo tempo)). } \\
\text { A5: Eu acho que a velocidade do chute ((inaudível)). } \\
\text { P: Eu acho... eu acho que como vocês estão hipotetizando... } \\
\text { aqui não é interessante agora... trabalhar com valores reais... é } \\
\text { interessante vocês trabalharem com valores que sejam fáceis } \\
\text { de usar... massa da bola... um quilo. } \\
\text { A5: AÎ... VIU? /// P: Velocidade da perna... metros por } \\
\text { segundo. } \\
\text { A5: DOIS QUILOS... eu estava falando até agora. ((A5 ficou } \\
\text { bravo com a estimativa errônea do colega, pois a sua foi mais } \\
\text { realista)). } \\
\text { A6: Mas uma bola tem } 2 \mathrm{~kg} . . . \text { né? } \\
\text { P: Não... uma bola tem } 500 \text { gramas... uma bola de futebol... } \\
\text { A6: De campo? }\end{array}$}} & $\begin{array}{c}\text { Cuidado com os dados } \\
\text { Definição das } \\
\text { variáveis relevantes ao } \\
\text { problema }\end{array}$ \\
\hline & & & Argumentação \\
\hline & & & $\begin{array}{c}\text { Seriação } \\
\text { Classificação e } \\
\text { organização dos dados } \\
\text { Abdução } \\
\text { Dedução }\end{array}$ \\
\hline $\begin{array}{l}\text { Tempo inicia } \\
\text { final da cen }\end{array}$ & & Transcrição, Descrição das ações e linguagens & Ciclo Argumentativo \\
\hline \multirow{3}{*}{\multicolumn{2}{|c|}{$00: 44: 30-00: 45: 20$}} & \multirow{3}{*}{$\begin{array}{l}\text { ((risos)) } \\
\text { P: Um quilo cara... um quilo de feijão... chuta um quilo } \\
\text { de feijão aí para tu ver. /// A5: Aí óh:.: eu não falei... eu } \\
\text { estava mais certo do que vocês... eu falei um quilo. } \\
\text { ((Professor vai ajudar outros grupos)). } \\
\text { A3: Eu falei...né? } \\
\text { A1: É aluno } 6 . \\
\text { A3: Eu falei e ele ficou dizendo que eu não entendia de } \\
\text { futebol. } \\
\text { A2: AH... eu quero voltar para a primeira série... ((risos)) } \\
\text { A3: Eu falei e ele falou eu não entendia de futebol. } \\
\text { A5: Eu falei... cara.... ele estava falando um quilo. }\end{array}$} & $\begin{array}{c}\text { Definição das } \\
\text { variáveis relevantes ao } \\
\text { problema }\end{array}$ \\
\hline & & & Argumentação \\
\hline & & & $\begin{array}{c}\text { Seriação } \\
\text { Classificação e } \\
\text { organização dos dados } \\
\text { Justificativa }\end{array}$ \\
\hline
\end{tabular}




\begin{tabular}{|c|c|c|}
\hline & $\begin{array}{l}\text { A1: Não dá cara. } \\
\text { A5: Mas "não... não... é muito leve" ((imitando e } \\
\text { caçoando A6)). } \\
\text { A2: Cara... mas parece ser mais pesada. } \\
\text { A6: Parece. } \\
\text { A3: Dois quilos ((desdenhando do colega)). } \\
\text { A5: Um quilo tem a de quadra então... a de quadra deve } \\
\text { ter um quilo então. Mas a hipotes/ ((para e fica } \\
\text { pensativo, o aluno } 6 \text { começa a apagar e os demais o } \\
\text { observam e depois começam a escrever. O aluno } 5 \\
\text { começa a escrever e falar)). } \\
\text { A5: Tá... meio quilo... não... é 500g. /// A6: Acabou tua } \\
\text { borracha. } \\
\text { A2: Quanto ele falou por hora? } \\
\text { A5: Empresta um lapisinho... um lápis? } \\
\text { A2: Um metro por segundo? } \\
\text { A1: É metros por segundo. } \\
\text { A5: É metros por segundo. }\end{array}$ & \\
\hline $\begin{array}{l}\text { Tempo inicial } \\
\text { e final da cena }\end{array}$ & Transcrição, Descrição das ações e linguagens & Ciclo Argumentativo \\
\hline \multirow[t]{3}{*}{$\begin{array}{c}00: 45: 20- \\
00: 45: 45\end{array}$} & \multirow{3}{*}{$\begin{array}{l}\text { A6: Quinhentas gramas uma bola? } \\
\text { A5: Quantos metros por segundo? } \\
\text { A2: Foi o que ele ((professor)) falou. } \\
\text { A1: Oitenta metros por segundo é:: } \\
\text { A5: Digamos que ele vá chutar de fora da grande área. } \\
\text { A1: Não o caso é um pênalti então. } \\
\text { A2: É um pênalti seu. } \\
\text { A5: Vai ser trinta metros por segundo. } \\
\text { A6: Trinta metros por segundo ((inaudível - coloca a mão na } \\
\text { boca)). } \\
\text { A5: Trinta por segundo. /// A2: Então faz aí. } \\
\text { A1: Não... não vai ser tudo isso. } \\
\text { A5: É quinze metros lá do pênalti né? ... MAS É HIPÓTESE } \\
\text { cara... não é para fazer o real... É hipótese. } \\
\text { A6: Então pode ser dez... dez metros por segundo. } \\
\text { A5: Não trint/vinte metros. /// A1: Então vamos botar } \\
\text { que/bota cem metros por segundo que tá valendo. } \\
\text { A2: Mas tem que ter quarenta... divide pela } \\
\text { metade((inaudível)). } \\
\text { A1: Então vai... vinte metros/vinte metros por segundo. } \\
\text { A2: Daí vai dividir e vai dar quarenta? } \\
\text { A1: Conseguiu? Conseguiu? ((para A5)). } \\
\text { A3: Vai dar quatro ((inaudível)). }\end{array}$} & $\begin{array}{l}\text { Cuidado com os dados } \\
\text { Definição das } \\
\text { variáveis relevantes ao } \\
\text { problema }\end{array}$ \\
\hline & & Argumentação \\
\hline & & $\begin{array}{c}\text { Seriação } \\
\text { Classificação e } \\
\text { organização dos dados } \\
\text { Hipótese } \\
\text { Justificativa } \\
\text { Abdução } \\
\text { Dedução }\end{array}$ \\
\hline $\begin{array}{l}\text { Tempo inicial } \\
\text { e final da cena }\end{array}$ & Transcrição, Descrição das ações e linguagens & Ciclo Argumentativo \\
\hline \multirow[t]{3}{*}{$\begin{array}{c}00: 50: 45- \\
00: 51: 30\end{array}$} & \multirow{3}{*}{$\begin{array}{l}\text { A5 ((ao ouvir o professor conversando com outro grupo)): } \\
\text { Ah:: vai ser... nós fizemos vinte coisa... né? Ela vai passar... } \\
\text { digamos que vai passar... quinze metros por segundo... e no } \\
\text { pé dele vai ficar cinco metros por segundo... entendeu? Vai } \\
\text { dividir o que o professor falou... PROFESSOR... } \\
\text { A6: ÔH PROFESSOR... dá uma mão aqui para nós? } \\
\text { A5: Como o professor falou ali... digamos... a gente tá } \\
\text { supondo que é vinte metros por segundo... daí ele passou e } \\
\text { ficou um pouco de movimento na perna... deixamos cinco } \\
\text { metros por segundo... daí passou quinze metr/ para a bola. } \\
\text { P: Não... tu passou quantidade de movimento... não } \\
\text { velocidade... } \\
\text { A6: É... movimento para a bola... é quinze... /// P: } \\
\text { Quantidade de movimento da bola. } \\
\text { P: Então o que passou... tu tinha quanto antes na perna? }\end{array}$} & $\begin{array}{c}\text { Definição das } \\
\text { variáveis relevantes ao } \\
\text { problema }\end{array}$ \\
\hline & & Argumentação \\
\hline & & $\begin{array}{c}\text { Classificação e } \\
\text { organização dos dados } \\
\text { Raciocínio Lógico e } \\
\text { proporcional }\end{array}$ \\
\hline
\end{tabular}




\begin{tabular}{|c|c|c|}
\hline & $\begin{array}{l}\text { A5 e A6: Vinte. } \\
\text { P: Tu passou quinze pra bola. } \\
\text { A5: Ficou cinco na perna. ((Professor vai ajudar outro } \\
\text { grupo)). }\end{array}$ & \\
\hline $\begin{array}{l}\text { Tempo inicial } \\
\text { e final da cena }\end{array}$ & Transcrição, Descrição das ações e linguagens & Ciclo Argumentativo \\
\hline \multirow[t]{3}{*}{$\begin{array}{c}00: 51: 50- \\
00: 52: 10\end{array}$} & \multirow{3}{*}{$\begin{array}{l}\text { A6: Vamos para a dois... dois dois dois... } \\
\text { A5 ((lendo a questão)): Consequentemente... qual é... qual é } \\
\text { a velocidade adquirida pelo/pela bola logo após o chute? } \\
\text { Quinze metros por segundo. } \\
\text { A6: Como? } \\
\text { A5: Quinze metros por segundo. } \\
\text { A6: Sim. }\end{array}$} & Explicação \\
\hline & & Argumentação \\
\hline & & $\begin{array}{c}\text { Justificativa } \\
\text { Previsão } \\
\text { Dedução }\end{array}$ \\
\hline
\end{tabular}

\section{Episódio 3 - Discussão coletiva sobre os problemas abertos}

\begin{tabular}{|c|c|c|}
\hline $\begin{array}{l}\text { Tempo inicial } \\
\text { e final da cena }\end{array}$ & Transcrição, Descrição das ações e linguagens & Ciclo Argumentativo \\
\hline \multirow{3}{*}{$\begin{array}{l}01: 07: 30- \\
01: 08: 20\end{array}$} & \multirow{3}{*}{$\begin{array}{l}\text { P: Então... eu diria o seguinte na hipótese... (colocaria uma } \\
\text { coisa) na hipótese... que é importantes vocês colocarem aqui } \\
\text { óh... que após a colisão... ((professor fala e escreve na } \\
\text { lousa)) a colisão de quem? } \\
\text { Alunos: Da perna com a bola. } \\
\text { P: Aqui óh... a perna fica:: } \\
\text { A7: Parada. } \\
\text { P: Parada... isso é fundamental... isso é fundamental você } \\
\text { colocar aqui... ou você colocaria 'após a colisão...' tá certo... } \\
\text { ‘a perna acompanha a bola'... 'após a colisão a perna volta } \\
\text { para::' ((faz gestos com a mão representando a fala)). } \\
\text { A9: Trás. } \\
\text { P: Trás... }\end{array}$} & $\begin{array}{c}\text { Definição das } \\
\text { variáveis relevantes ao } \\
\text { problema } \\
\text { Explicação } \\
\end{array}$ \\
\hline & & Argumentação \\
\hline & & $\begin{array}{l}\text { Hipótese } \\
\text { Justificativa }\end{array}$ \\
\hline $\begin{array}{l}\text { Tempo inicial } \\
\text { e final da cena }\end{array}$ & Transcrição, Descrição das ações e linguagens & Ciclo Argumentativo \\
\hline \multirow[t]{3}{*}{$\begin{array}{l}01: 08: 20- \\
01: 08: 30\end{array}$} & \multirow{3}{*}{$\begin{array}{l}\text { P: Se tu colocou essa condição aqui... então tu tá dizendo } \\
\text { que o 'Q' antes... } \\
\text { A9: Vai se transferir inteiro para a bola. } \\
\text { P: Daí tu vai colocar aquela assim óh:.... desenha o pé... } \\
\text { desenha a bola... isso aqui é o que? ((desenha o pé e a bola } \\
\text { na lousa antes da colisão)). O antes... esse aqui é o famoso } \\
\text { perna de pau... } \\
\text { A9: É um 'P' ou um 'b"? ((sobre o desenho do professor)). } \\
\text { P: É uma perna cara. }\end{array}$} & $\begin{array}{c}\text { Definição das } \\
\text { variáveis relevantes ao } \\
\text { problema } \\
\text { Explicação } \\
\end{array}$ \\
\hline & & Argumentação \\
\hline & & $\begin{array}{c}\text { Dedução } \\
\text { Justificativa }\end{array}$ \\
\hline $\begin{array}{l}\text { Tempo inicial } \\
\text { e final da cena }\end{array}$ & Transcrição, Descrição das ações e linguagens & Ciclo Argumentativo \\
\hline \multirow[t]{3}{*}{$\begin{array}{l}01: 08: 30- \\
01: 09: 40\end{array}$} & \multirow{3}{*}{$\begin{array}{l}\text { P: E aqui vai desenhar o:: depois... ok? ((desenha o pé e a } \\
\text { bola na lousa depois da colisão)) Aqui ((apontando o } \\
\text { antes))... qual a quantidade de movimento da perna? } \\
\left(\left(\text { escreve embaixo do desenho da perna antes da colisão ' } \mathrm{Q}_{\mathrm{P}}\right.\right. \\
\left.\left.=15^{\prime}\right)\right) \text {. } \\
\text { A7: QUINZE. } \\
\text { P: Dá quinze... qual é a quantidade de movimento da bola? } \\
\text { Alunos: Zero! }((\text { escreve embaixo do desenho da bola antes } \\
\left.\left.\text { da colisão ' } \mathrm{Q}_{\mathrm{B}}=0^{\prime}\right)\right) \text {. }\end{array}$} & $\begin{array}{c}\text { Definição das } \\
\text { variáveis relevantes ao } \\
\text { problema } \\
\text { Explicação } \\
\end{array}$ \\
\hline & & Argumentação \\
\hline & & $\begin{array}{c}\text { Classificação e } \\
\text { organização dos dados }\end{array}$ \\
\hline
\end{tabular}




\begin{tabular}{|c|c|c|}
\hline & $\begin{array}{l}\text { P: Depois do choque... qual é a quantidade de movimento da } \\
\text { perna? ((escreve embaixo do desenho da perna depois da } \\
\text { colisão 'Q } Q_{\mathrm{P}}=0 \text { ')). } \\
\text { Alunos: Quinze... quinze... zero. } \\
\text { P: Zero? Porque que é zero? } \\
\text { A7: Porque transferiu para a bola. } \\
\text { P: Porque lá na hipótese colocou óh:: que após a colisão a } \\
\text { perna fica o quê? } \\
\text { A7: Parada. } \\
\text { A5: Parada. } \\
\text { P: Parada. Então quer dizer que a quantidade de movimento } \\
\text { da bola... tem que ser quanto? ((escreve ' } Q_{\mathrm{B}}=\text { ?' do lado da } \\
\text { bola, no desenho depois da colisão)). } \\
\text { A5: Quinze... AH... tem que saber. } \\
\text { P: Então a matemática aqui óh:.... a quantidade de antes tem } \\
\text { que ser igual a quantidade de movimento o quê? }((\text { fala e } \\
\text { escreve ' } Q_{\text {antes }}=\mathrm{Q}_{\text {depois' na lousa abaixo dos desenhos })) . . .} \\
\text { aqui é a quantidade da perna mais a quantidade da bola... } \\
\left(\left(\text { professor escreve 'Q } Q_{\mathrm{P}}+\mathrm{Q}_{\mathrm{B}} \text { ' em baixo de 'Q } \mathrm{Q}_{\text {antes }}\right)\right) \text { tem que } \\
\text { ser igual a quantidade de movimento da perna mais a da } \\
\text { quantidade da::... ((professor escreve '= } \mathrm{Q}_{\mathrm{P}}+\mathrm{Q}_{\mathrm{B}} \text { ' em baixo } \\
\left.\left.\text { de 'Q } \mathrm{Q}_{\text {depois }}\right)\right) \text {. } \\
\text { A6: Bola. }\end{array}$ & $\begin{array}{c}\text { Dedução } \\
\text { Justificativa }\end{array}$ \\
\hline $\begin{array}{l}\text { Tempo inicial } \\
\text { e final da cena }\end{array}$ & Transcrição, Descrição das ações e linguagens & Ciclo Argumentativo \\
\hline \multirow[t]{3}{*}{$\begin{array}{c}01: 09: 40- \\
01: 10: 30\end{array}$} & \multirow{3}{*}{$\begin{array}{l}\text { P: O que dá para nós simplificarmos ali... que é zero? } \\
\text { A10: Trinta... trinta. } \\
\text { P: Quantidade da bola antes é quanto? } \\
\text { A?: Quinze. } \\
\text { A6: zero ((professor faz uma seta apontando para o número } \\
\text { zero em cima da } Q_{B} \text { antes da colisão)). } \\
\text { P: DÁ BOLA. } \\
\text { A6: Ah da bola. } \\
\text { P: Qual é a quantidade do depois da perna? } \\
\text { Alunos: zero ((professor faz uma seta apontando para o } \\
\text { número zero em cima da } Q_{P} \text { depois da colisão)). } \\
\text { P: Ou seja... a quantidade de movimento da perna é igual a } \\
\text { quantidade de movimento da bola... que é de quanto? } \\
\left.\left.\text { ((escreve } Q_{P}=Q_{B}\right)\right) \text {. } \\
\text { A6: Quinze metros por segundos. } \\
\text { P: Quinze quilogramas vezes metros por:: ((completa a } \\
\left.\left.\text { escrita } Q_{P}=Q_{B}=15 \mathrm{~kg} . \mathrm{m} / \mathrm{s}\right)\right) \text {. } \\
\text { A6: Segundos. } \\
\text { P: Segundos. }\end{array}$} & $\begin{array}{c}\text { Definição das } \\
\text { variáveis relevantes ao } \\
\text { problema } \\
\text { Explicação }\end{array}$ \\
\hline & & Argumentação \\
\hline & & $\begin{array}{c}\text { Classificação e } \\
\text { organização dos dados } \\
\text { Dedução }\end{array}$ \\
\hline $\begin{array}{l}\text { Tempo inicial } \\
\text { e final da cena }\end{array}$ & Transcrição, Descrição das ações e linguagens & Ciclo Argumentativo \\
\hline \multirow[t]{3}{*}{$\begin{array}{c}01: 10: 30- \\
01: 12: 00\end{array}$} & \multirow{3}{*}{$\begin{array}{l}\text { P: O que seria o último aqui? Análise dos resultados... } \\
\text { ((Professor fala e escreve no quadro "5 - Análise dos } \\
\text { Resultados")) OK? Volto na pergunta lá.... qual a máxima } \\
\text { quantidade de movimento você consegue transferir... a uma } \\
\text { bola durante o pênalti?... qual a máxima quantidade de } \\
\text { movimento você consegue transferir... a uma... } \\
\text { A7: Em relação às nossas hipóteses... quinze quilograma/. } \\
\text { P: Em relação às nossas hipóteses... vou colocar aqui na } \\
\text { primeira pessoa... tá? Minha hipótese.... consigo... eu não } \\
\text { consigo... né... na verdade... é trans-fe-rida toda a quantidade } \\
\text { de movi-mento ((professor fala e escreve no quadro)). } \\
\text { ((Conversa entre A5 e A2 paralela à discussão promovida } \\
\text { pelo professor)): } \\
\text { A5: Foi o mesmo resultado que o nosso... deu quinze }\end{array}$} & Explicação \\
\hline & & Argumentação \\
\hline & & $\begin{array}{c}\text { Hipótese } \\
\text { Justificativa }\end{array}$ \\
\hline
\end{tabular}




\begin{tabular}{|c|c|c|}
\hline & & $\begin{array}{l}\text { também o nosso. } \\
\text { A2: Só que eles fizeram... um pouco mais elaborado... o } \\
\text { nosso foi mais no chute... tá ligado ((ocorrem também } \\
\text { conversas paralelas sobre a chuva)). } \\
\text { A5: Deu o mesmo resultado que o nosso. }\end{array}$ \\
\hline
\end{tabular}

\section{Aulas 7 e 8 - 07-06-2013}

<00:000:06> P: Então é o seguinte, hoje nós vamos trabalhar, fazer duas propostas de trabalho pra vocês, primeira é essa folhinha que eu dei pra vocês, duas atividades ali, e depois, num segundo momento, nós vamos ter mais duas atividades. Hoje o que a gente vai estudar é uma consequência da conservação da quantidade de movimento que a gente viu, certo?! Então hoje a gente vai trabalhar com os choques, também podem ser chamados de colisão. No primeiro momento a gente vai trabalhar com o choque que a gente identifica como INELÁSTICO. Então assim, o que é a característica desse choque, a principal característica desse choque é, aqui tem dois corpos, pode ter três, quatro, cinco... E a principal característica desse aqui é que quando houver a colisão, esses dois corpos vão se tornar apenas um corpo. Então eu dei essa folha pra vocês, pra gente testar algumas grandezas aqui, pra gente determinar qual é a velocidade que vai ser após a colisão desses corpos unidos, então vamos testar algumas hipóteses com vocês agora, e no segundo momento, eu preparei uma atividade para vocês, que é pra nós trabalharmos um problema aberto, certo? Que é do astronauta ali, então olha só, no primeiro quadrinho de vocês aqui (professor vai para o quadro explicar), eu tenho dois corpos e nós vamos hipotetizar aqui: massas, e? Velocidades e vamos dizer para onde esse corpo está indo. Então vamos pegar o primeiro corpo aqui e vamos dar um valor de massa para ele. Sugestões?

$<00: 02: 21>$ Aluno: 7

<00:02:22> P: 7. Posso dar uma sugestão para facilitar a nossa vida no sentido de cálculo? Vamos dar números redondos

$<00: 02: 35>$ Alunos: 10

$<00: 02: 36>$ P: 10 . Esse corpo aqui tem 10kg. O outro corpo terá quantos $\mathrm{kg}$ ?

$<00: 02: 46>$ Alunos: 20.

<00:02:50> P: 20kg. Muito bem, agora nós temos que definir, para onde esses corpos estarão se dirigindo para haver uma colisão, então, vamos supor que o corpo A está indo pra frente, se ele está indo para a frente eu posso representar com um vetor que esse corpo está indo pra lá e obviamente que eu vou ter que determinar qual a velocidade com que esse corpo está indo pra lá. Vamos colocar alguma velocidade, 2,3,4 5m/s. Muito bem. O segundo corpo, agora temos que fazer uma opção, ele está indo para a direita ou ele está vindo para a esquerda?

$<00: 04: 02>$ Aluno: Indo pra direita.

$<00: 04: 03>$ P: Indo para a direita. Muito bem, e qual a velocidade desse corpo aqui então?

$<00: 04: 10>$ Aluna: Tem que ser uma velocidade menos que a...

$<00: 04: 15>$ P: Como?

$<00: 04: 17>$ Aluna: Não tem que ser uma velocidade... porque se vai unir, tem que ser uma menor que a... 
<00:04:21> Aluno: Ou então coloca 10 daí ali fica 5.

$<00: 04: 25>$ P: Não, mas veja bem aqui a Aluna ta colocando, ela ta dizendo que tem que ser uma velocidade o que?

$<00: 04: 30>$ Alunos: Menor.

$<00: 04: 31>$ P: Por quê?

$<00: 04: 32>$ Alunos: Porque eles não vão se unir, se ele tiver uma velocidade maior...

$<00: 04: 37>$ P: Porque eles não vão se encontrar. Vocês concordam com isso aí?

$<00: 04: 39>$ Alunos: Sim.

$<00: 04: 40>$ P: Olha aqui, se este aqui estiver com uma velocidade maior que esse aqui, nunca vai haver uma colisão.

$<00: 04: 48>$ Aluna: É igual tipo racha de carro.

$<00: 04: 51>$ P: O que é racha de carro?

$<00: 04: 52>$ Aluna: Corrida.

<00:04:59> P: Então assim, vocês concordam com isso aí? Que esse carro da frente, nessa situação tem que ter uma velocidade menor? Beleza, qual a velocidade? 2? 3? Então ta, isso aqui foram as minhas condições iniciais da minha colisão, como esse carro está com uma velocidade maior, ele vai bater lá, vai colidir, beleza? Bom, como eu disse que é um choque inelástico, a característica diz que esses corpos vão colidir e depois da colisão eles vai continuar andando juntos, certo?! Isso quer dizer que eu poso dizer que esses dois objetos aqui, esses dois corpos, vão estar andando com a mesma velocidade, que eu vou identificar aqui chamando velocidade $A B$, eu vou supor que esse aqui é meu carro A e isso aqui é meu carro B, meu automóvel, meu objeto, ta certo?! Agora vou perguntar pra vocês o seguinte: se esses carros estão andando junto aqui, eu não posso dizer que aquilo é um único corpo?

$<00: 06: 25>$ Alunos: Sim.

$<00: 06: 26>$ P: E qual é a massa desse corpo?

$<00: 06: 27>$ Alunos: 30.

$<00: 06: 35>$ Olha aqui, a massa desse corpo vale $30 \mathrm{~kg}$.

$<00: 06: 40>$ Aluno: E a velocidade?

<00:06:41> P: A velocidade é o que eu quero saber, entendeu? Eu quero saber o seguinte, ta indo, bateu, vou andar junto, qual a velocidade desses dois corpos? Isso aqui, gente, vai partir para uma análise quantitativa. A análise qualitativa nós fizemos, acabei de perguntar para vocês "será que a velocidade vai ser maior ou menor?" não tem como responder isso se eu não fizer uma análise matemática. Eu vou hipotetizar, mas eu não vou poder chegar a uma conclusão sem eu fazer o que? Contas! Sem usar o que? Matemática. E agora o que eu faço então? Olha aqui, segundo o que a gente viu nas outras aulas, o movimento tem que ser conservado. Ou seja, a quantidade de movimento que eu tinha antes vai ter que ser o que? Igual à quantidade de movimento que eu tenho depois. Olha só, a quantidade de movimento que eu tinha antes, o Q é quantidade de movimento, antes, eu vou ter dois objetos, na verdade a quantidade de movimento que eu tenho antes vai ser igual a quantidade de movimento do carro A mais a quantidade de movimento do carro B. e do outro lado lá? Eu vou ter dois corpos ou um corpo só? Então eu posso afirmar que a quantidade do grupo AB. Como eu calculo a quantidade movimento aqui?

$<00: 08: 50>$ A: Faz massa vezes a velocidade.

$<00: 08: 52>$ P: Massa vezes velocidade mais massa vezes velocidade. E aqui pra ficar bem bonitinho e tudo certo vou colocar um subscrito aqui pra dizer que é massa do A e velocidade do A e aqui é a massa do $\mathrm{B}$ vezes a velocidade do $\mathrm{B}$. La no outro lado o que vamos colocar? Massa $A B$ vezes velocidade $A B$. Agora vamos substituir valores. Massa do A? 10. Vezes velocidade do A, 5 mais massa do B, 20 mais a velocidade do B, 2. 
Isso aqui é tudo igual, massa $A B, 30$ vezes velocidade $A B$ que eu não sei. 10 vezes 5 ? 50 , mais 20 vezes 2,40 igual a 30 vezes velocidade $A B$. Olha só, faltou quadro, vou vir pra cá. Vocês vão continuar embaixo, quanto dá isso aí? (prof se refere à soma)

$<00: 100: 46>$ A: 90 .

$<00: 100: 48>$ P: Igual a $30 \mathrm{Vab}$. Quero saber quem?

$<00: 100: 58>$ A: Velocidade.

$<00: 100: 59>$ P: Quem está me atrapalhando?

$<00: 11: 03>$ A: O igual, o 30, divide, divide.

$<00: 11: 03>$ P: Eu tenho que tirar esse 30 daqui.

$<00: 11: 05>$ A: Divide.

<00:11:06> P: Se ele está multiplicando, eu passo para o outro lado fazendo a operação matemática inversa. Então, 90 sobre 30 é igual a Vab. Agora olha aqui, o teu Vab será igual a?

$<00: 11: 35>$ A: 3, deixa eu ver aqui.

<00:11:37> P: Calma aí, aqui ó, corta, corta (os zeros), 9 dividido por 3 ? 3 o que? Metros por segundo $(\mathrm{m} / \mathrm{s})$. Gente olha só, o que eu quero que vocês assimilem, tem problemas as vezes que tu consegue chegar num resultado qualitativo, mas tem problemas de Física, como esses de colisão, que eu não vou chegar num resultado qualitativo, a minha resposta vai ter que ser um resultado quantitativo, então eu tenho que chegar num valor, como eu cheguei agora. Então, qual a velocidade do grupo?

$<00: 12: 20>\mathrm{A}: 3 \mathrm{~m} / \mathrm{s}$

$<00: 12: 21>$ P: $3 \mathrm{~m} / \mathrm{s}$. então se eu tivesse feito a pergunta: qual a velocidade do grupo?, ta aqui (aponta os $3 \mathrm{~m} / \mathrm{s}$ ). agora eu poderia fazer outra pergunta: a velocidade aumenta ou diminui?

$<00: 12: 35>$ A: Diminui.

<00:12:37> P: Depende em relação a qual corpo eu perguntei, em relação ao corpo A (acaba assim mesmo). Agora é o seguinte: terminem de copiar que a gente vai fazer uma coisa muito louca agora.

(discussão sobre onde copiar o exercício)

<00:13:40> P: Agora quero fazer uma pergunta pra vocês: se eu inverter essas massas (aponta os círculos no quadro), vai ter diferença?

$<00: 13: 43>$ A: Vai.

$<00: 14: 00>$ P: A proposta que eu quero fazer agora pra vocês, já copiaram essa parte de cima aqui?

$<00: 14: 03>$ A: Não

<00:14:04> P: Deixa eles terminarem ali, a proposta que eu quero fazer para vocês é que nós vamos inverter essas massas, vamos manter as velocidades e vamos inverter as massas, certo? No primeiro nós vamos botar 20 e no segundo... (inaudível).

(Alunos copiam as atividades do quadro)

<00:17:09> P: Olha aqui, ó. Sugestão para o segundo, nessa folhinha mesmo, pode fazer, nós vamos substituir as massas, vamos colocar $20 \mathrm{~kg}$ agora na A e $10 \mathrm{~kg}$ na B. dois minutos para fazer agora, essa sequência de debaixo. Troquem as massas, a velocidade não muda. No segundo desenho (da folha) isso aí, inverte as massas

$<00: 18: 55>$ A: Professor, mas lá no depois, vai ser a mesma quantia.

$<00: 19: 00>$ P: Aqui altera?

$<00: 19: 01>$ A: Não.

(Alunos conversam em grupo)

<00:19:28> A6: Qual a lógica desse depois aqui? Velocidade. Eu vou fazer tudo esse bagulho aqui, só que vou trocar.

$<00: 19: 47>$ A2: Só copia, cara, só copia e muda. 
(Alunos conversam em grupo)

$<00: 200: 33>$ Professor vem verificar o grupo estudado, olha a folha do A2 e fala 'isso aí!'.

(Alunos conversam em grupo)

$\langle 00: 21: 25>$ A6: 20 vezes 5 vai dar 100 .

$<00: 21: 26>$ A2: Mas porquê esse 30? Ah, 30 é o peso.

$<00: 21: 59>$ P: Vamos lá?

$<00: 21: 59>$ A: Calma aí, não.

$<00: 22: 01>$ A6: Professor, vai dar 4.

$<00: 22: 15>$ A2: Faz aí, 100/30.

$<00: 22: 17>$ A6: Vai dar 4.

$<00: 22: 22>$ A2: Mas por que 4 no caso? Professor, vem aqui! Aí se estiver errado, eu choro. 120? Deixa eu ver por que deu 120? Não deu 100?

$<00: 22: 58>$ A6: Pior que não, deu 120.

<00:23:00> P: Vamos conferir isso aqui. Aqui ó, massa 20 vezes 5 mais 10 vezes 2, quantidade de movimento, somei, 120 igual a 30, 120 ó, ó (cortou os zeros), 12 dividido por $3 ? 4 \mathrm{~m} / \mathrm{s}$. o que eu quero dizer pra ti, ó, não adianta, para você resolver um problema desse aqui, se tu não usar matemática, se tu não arrumar esse algoritmo, se tu não perceber que é um choque elástico, tu não vai conseguir chegar num resultado. Então tem que seguir esse algoritmo aqui e utilizar o cálculo para chegar num resultado.

$<00: 24: 20>$ A6: E agora o último, qual vai ser? A próxima hipótese?

$<00: 24: 29>$ P: Pessoal! Ok? Rápido, rápido, rápido.

Episódio 4 - Problemas abertos sobre colisões inelásticas

\begin{tabular}{|c|c|c|}
\hline $\begin{array}{c}\text { Tempo } \\
\text { inicial e final } \\
\text { da cena }\end{array}$ & Transcrição, Descrição das ações e linguagens & Ciclo Argumentativo \\
\hline \multirow[t]{3}{*}{$\begin{array}{l}00: 25: 50 \\
00: 26: 50\end{array}$} & \multirow{3}{*}{$\begin{array}{l}\text { P: Agora nós vamos fazer... uma colisão frontal... ok?... uma } \\
\text { colisão frontal... vamos:.... vamos dar uma massa aqui... } \\
\text { querem manter vinte quilos? Dez quilos? Qual vocês querem? } \\
\text { A9: Nós queremos dez. } \\
\text { P: Dez quilos? Ok. /// A10: Cinco quilos... cinco quilos. } \\
\text { P: Cinco quilogramas... } \\
\text { As: Não... oito... vinte... cinco... quarenta e nove. } \\
\text { P: Óh... xi:.... Vamos... vamos dar número redondo senão lá na } \\
\text { divisão depois a gente vai ter que... /// Alunos: Vinte... } \\
\text { quarenta...cinco... dez... } \\
\text { P: Ta ok... vou usar vinte quilogramas aqui... }\end{array}$} & $\begin{array}{l}\text { Cuidado com os dados } \\
\text { Definição das } \\
\text { variáveis relevantes ao } \\
\text { problema }\end{array}$ \\
\hline & & Argumentação \\
\hline & & $\begin{array}{c}\text { Seriação } \\
\text { Classificação e } \\
\text { organização dos dados }\end{array}$ \\
\hline $\begin{array}{c}\text { Tempo } \\
\text { inicial e final } \\
\text { da cena } \\
\end{array}$ & Transcrição, Descrição das ações e linguagens & Ciclo Argumentativo \\
\hline \multirow[t]{3}{*}{$\begin{array}{c}00: 26: 50- \\
00: 27: 50\end{array}$} & \multirow{3}{*}{$\begin{array}{l}\text { P: Só que esse carinha está vindo pra cá ((desenha uma seta no } \\
\text { corpo A apontando da esquerda para a direita)) e esse está } \\
\text { vindo pra cá ((desenha uma seta no corpo B apontando da } \\
\text { direita para a esquerda))... agora aqui eu vou apagar isso aqui } \\
((\text { apaga a seta no desenho dos carros juntos depois da } \\
\text { colisão) }) . . \text { eu não vou... dizer que isso aqui está vindo para cá } \\
((\text { faz gesto indicando o lado direito da lousa))... por que eu } \\
\text { tenho como afirmar se está vindo para cá? }((\text { repete gesto })) . .\end{array}$} & $\begin{array}{l}\text { Cuidado com os dados } \\
\text { Definição das } \\
\text { variáveis relevantes ao } \\
\text { problema }\end{array}$ \\
\hline & & Argumentação \\
\hline & & $\begin{array}{c}\text { Seriação } \\
\text { Classificação e }\end{array}$ \\
\hline
\end{tabular}




\begin{tabular}{|c|c|c|}
\hline & $\begin{array}{l}\text { A9: Tenho:.... não... } \\
\text { P: Ou isso aqui está indo pra lá? ((faz gesto apontando para o } \\
\text { lado esquerdo da lousa)). } \\
\text { A9: Isso aqui está indo pra lá ((provavelmente se referindo } \\
\text { apenas a um dos objetos)). } \\
\text { P: Não... o final... o grupo... isso aqui vai andar pra esquerda } \\
\text { ou para a direita? ((faz gestos indicando as direções)). } \\
\text { Alunos: Para a direita... esquerda... no meio... } \\
\text { A7: tem que fazer a conta. } \\
\text { A10: Não... para esquerda... para esquerda ((aponta)). } \\
\text { A6: Não ele vai andar para a esquerda. } \\
\text { A?: Tem que fazer a conta professor. } \\
\text { A7: Tem que fazer a conta primeiro. } \\
\text { A6: ((inaudível))... direto... tanto para um lado quanto para o } \\
\text { outro. }\end{array}$ & $\begin{array}{c}\text { organização dos dados } \\
\text { Previsão }\end{array}$ \\
\hline $\begin{array}{c}\text { Tempo } \\
\text { inicial e final } \\
\text { da cena }\end{array}$ & Transcrição, Descrição das ações e linguagens & Ciclo Argumentativo \\
\hline \multirow[t]{3}{*}{$\begin{array}{c}00: 27: 50- \\
00: 28: 20\end{array}$} & \multirow{3}{*}{$\begin{array}{l}\text { A10: O vinte quilos fica parado... o dez vai para a esquerda. } \\
\text { A7: Não não não não vai pra... vai pra direita... porque a } \\
\text { velocidade ali é maior óh. } \\
\text { A?: Porque a massa é menor. /// P: Olha aqui óh... } \\
\text { P: Ok... só um pouquinho... mas é só a velocidade que define } \\
\text { para onde ele vai? } \\
\text { A7: Não não não não não tem que fazer a quantidade de } \\
\text { movimento... } \\
\text { P: Tem que fazer o quê? } \\
\text { A9: A quantidade de movimento antes. } \\
\text { A7: Não antes do carro... não antes ((inaudível)). } \\
\text { A9: É:.... hã? } \\
\text { A7: É porque ele tem quantidade antes e quantidade depois. }\end{array}$} & $\begin{array}{c}\text { Definição das } \\
\text { variáveis relevantes ao } \\
\text { problema } \\
\text { Explicação }\end{array}$ \\
\hline & & Argumentação \\
\hline & & $\begin{array}{c}\text { Seriação } \\
\text { Classificação e } \\
\text { organização dos dados } \\
\text { Justificativa } \\
\text { Abdução } \\
\text { Previsão }\end{array}$ \\
\hline $\begin{array}{c}\text { Tempo } \\
\text { inicial e final } \\
\text { da cena } \\
\end{array}$ & Transcrição, Descrição das ações e linguagens & Ciclo Argumentativo \\
\hline \multirow[t]{3}{*}{$\begin{array}{c}00: 28: 20- \\
00: 28: 40\end{array}$} & \multirow{3}{*}{$\begin{array}{l}\text { P: Xiii::: Esse grupo aqui o que que acha? } \\
\text { A10: Vai para o lado esquerdo porque... /// P: Mas por que tu } \\
\text { acha que vai para a esquerda aluno } 10 \text { ? } \\
\text { A10: Porque vinte quilos é mais pesado se bater... se bater..../// } \\
\text { P: Mas... depende só da massa? } \\
\text { As: Não... } \\
\text { A?: A velocidade } \\
\text { A7: E a velocidade... } \\
\text { A12: Mas não vai bater. /// A13: É porque lá ((inaudível)). } \\
\text { A11: Professor... eu acho que a velocidade dobra... a } \\
\text { velocidade dobra o peso não dobra? /// A10: Ele para TRÁS... } \\
\text { ele vai para esquerda. ((vários alunos falam ao mesmo } \\
\text { tempo)). } \\
\text { P: ISSO AÍ. }\end{array}$} & $\begin{array}{c}\text { Definição das } \\
\text { variáveis relevantes ao } \\
\text { problema } \\
\text { Explicação } \\
\end{array}$ \\
\hline & & Argumentação \\
\hline & & $\begin{array}{c}\text { Justificativa } \\
\text { Previsão } \\
\text { Raciocínio lógico e } \\
\text { proporcional } \\
\text { Abdução }\end{array}$ \\
\hline $\begin{array}{c}\text { Tempo } \\
\text { inicial e final } \\
\text { da cena }\end{array}$ & Transcrição, Descrição das ações e linguagens & Ciclo Argumentativo \\
\hline \multirow[t]{3}{*}{$\begin{array}{l}00: 28: 40 \quad- \\
00: 29: 50\end{array}$} & \multirow{3}{*}{$\begin{array}{l}\text { P: ...vocês aí no fundo o que acham? } \\
\text { As: Vai para esquerda. } \\
\text { P: Grupo das meninas aqui. } \\
\text { A?: Para esquerda. } \\
\text { P: Para esquerda ou pra direita? } \\
\text { Alunos: Para esquerda. } \\
\text { A11: Eu acho que o de dez ganha. } \\
\text { P: Para esquerda... assim óh... essa dúvida nossa aqui... nós } \\
\text { vamos resolver na conta... então ficou uma ... né... uma coisa }\end{array}$} & $\begin{array}{c}\text { Definição das } \\
\text { variáveis relevantes ao } \\
\text { problema } \\
\text { Explicação }\end{array}$ \\
\hline & & Argumentação \\
\hline & & $\begin{array}{c}\text { Classificação e } \\
\text { organização dos dados } \\
\text { Justificativa }\end{array}$ \\
\hline
\end{tabular}




\begin{tabular}{|c|c|c|}
\hline & $\begin{array}{l}\text { óbvia para nós todos aqui... certo? Ficou uma coisa óbvia para } \\
\text { nós todos aqui... então o que vai poder responder para nós na } \\
\text { verdade vai ser o que? } \\
\text { A?: Na conta. } \\
\text { A?: A matemática. } \\
\text { P: Matemática. } \\
\text { P: Certo? } \\
\text { A9: Eu odeio ela ((em tom de brincadeira)). } \\
\text { P: Tu vai adorar ela agora... Então olha só aqui... vamos lá... } \\
\text { massa do corpo A... } \\
\text { A9: Dez... } \\
\text { P: Velocidade do corpo A. } \\
\text { A10: Cinco. } \\
\text { P: Qual é a massa do corpo B? } \\
\text { A10: (Vinte). } \\
\text { P: Qual é a velocidade do corpo B? } \\
\text { A10: Dois. } \\
\text { P: E agora vem o problema aqui... xi... }\end{array}$ & $\begin{array}{l}\text { Previsão } \\
\text { Dedução }\end{array}$ \\
\hline $\begin{array}{c}\text { Tempo } \\
\text { inicial e final } \\
\text { da cena }\end{array}$ & Transcrição, Descrição das ações e linguagens & Ciclo Argumentativo \\
\hline \multirow[t]{3}{*}{$\begin{array}{l}00: 29: 50 \\
00: 31: 00\end{array}$} & \multirow{3}{*}{$\begin{array}{l}\text { P: Olha aqui óh... vamos relembrar lá do primeiro bimestre... } \\
\text { qual velocidade é maior... MAIS dez metros por segundo ou } \\
\text { MENOS dez metros por segundo? ((professor fala e escreve } \\
\text { os valores na lousa)). } \\
\text { A?: É a mesma. } \\
\text { P: É A MESMA? } \\
\text { A9: Eu acho que não... } \\
\text { P: Vamos... fala. } \\
\text { A8: Uma vai para um lado e outra vai para o outro. } \\
\text { P: Uma vai para um lado e a outra vai para o outro... A14... } \\
\text { concorda ou discorda? } \\
\text { A?: Concordo... } \\
\text { P: Discorda? } \\
\text { A14: Não... eu concordo. } \\
\text { P: Concorda também? Então olha aqui... isso aqui gente... é } \\
\text { fundamental... fundamental... certo? ((apontando para o } \\
\text { "+10m/s" e para o “-10m/s"))... nós reconhecermos que } \\
\text { quando eu tenho sentidos opostos ((junta os dois dedos } \\
\text { indicadores formando uma linha reta))...eu tenho que usar } \\
\text { sinais... diferentes... SE eu não fizer isso aí... a minha } \\
\text { ferramenta matemática... em vez de me ajudar... vai me... } \\
\text { atrapalhar... então olha só... qual é o detalhe aqui... SE ESSE } \\
\text { corpo está indo pra esquerda ((aponta para o corpo B))... }\end{array}$} & $\begin{array}{c}\text { Definição das } \\
\text { variáveis relevantes ao } \\
\text { problema } \\
\text { Explicação }\end{array}$ \\
\hline & & Argumentação \\
\hline & & $\begin{array}{c}\text { Classificação e } \\
\text { organização dos dados }\end{array}$ \\
\hline $\begin{array}{c}\text { Tempo } \\
\text { inicial e final } \\
\text { da cena }\end{array}$ & Transcrição, Descrição das ações e linguagens & $\begin{array}{c}\text { Ciclo } \\
\text { Argumentativo }\end{array}$ \\
\hline \multirow[t]{3}{*}{$\begin{array}{l}00: 31: 00 \quad- \\
00: 32: 40\end{array}$} & \multirow{3}{*}{$\begin{array}{l}\text { P: A velocidade dele então é ne-ga- } \\
\text { A6: Tiva ((completando a fala do professor.))... } \\
\text { P: Tiva... então aqui tu vai ter que abrir um parênteses e colocar o } \\
\text { sinal de ne-ga- ((professor fala e escreve ao longo dessa cena)). } \\
\text { A10: Tivo. } \\
\text { P: Tivo... legal? Então olha lá... Dez vezes cinco? } \\
\text { A6: Cinquenta. } \\
\text { P: VINTE vezes dois? } \\
\text { A6: Quarenta. } \\
\text { A?: Quarenta. } \\
\text { A7: Menos quarenta. } \\
\text { A6: Menos quarenta. } \\
\text { P: Mas... mais com menos vai dá quando? }\end{array}$} & $\begin{array}{c}\text { Definição das } \\
\text { variáveis relevantes } \\
\text { ao problema } \\
\text { Explicação }\end{array}$ \\
\hline & & Argumentação \\
\hline & & Dedução \\
\hline
\end{tabular}




\begin{tabular}{|c|c|c|}
\hline & \multicolumn{2}{|l|}{$\begin{array}{l}\text { As: Menos. } \\
\text { (A11): Por que vinte menos dois vai dar quarenta? } \\
\text { P: Menos então o que? Quarenta... isso sobra quanto então? } \\
\text { A9: Quarenta... é dez... } \\
\text { P: Dez... dividido por... } \\
\text { A9: Trinta... é zero vírgula três ((sobre o resultado da conta)). } \\
\text { P: Tá certo? Corta isso aqui... sobra quanto? } \\
\text { A10: Dois. } \\
\text { P: Um... terço... se eu dividir um por três... } \\
\text { A10: Vai dar um... } \\
\text { P: Um é menor... zero vírgula... eu vou bota... } \\
\text { A7: Vai dar uma dízima periódica... } \\
\text { P: Três vezes três... nove... sobra um... abaixa o outro zero... que } \\
\text { vai dar o que? } \\
\text { A9: Dá dízima periódica. } \\
\text { P: Dízima periódica... portanto eu fecho aqui com duas casas } \\
\text { decimais... }\end{array}$} \\
\hline $\begin{array}{c}\text { Tempo } \\
\text { inicial e final } \\
\text { da cena }\end{array}$ & Transcrição, Descrição das ações e linguagens & Ciclo Argumentativo \\
\hline \multirow[t]{3}{*}{$\begin{array}{l}00: 32: 40 \\
00: 35: 35\end{array}$} & \multirow[b]{3}{*}{$\begin{array}{l}\text { P: Agora é o seguinte... para a direita ou para a esquerda? } \\
\text { A10: Para a esquerda. } \\
\text { A6: Para a esquerda. } \\
\text { A10: Para a esquerda. } \\
\text { A6 ((para o seu grupo)): Dá positivo. } \\
\text { P: Mas POR QUE? } \\
\text { A?: Para a Direita. } \\
\text { A11: Para a Direita. } \\
\text { A7: Para cá... porque não deu negativo. } \\
\text { P: Para direita ou para esquerda A14? Por quê? } \\
\text { A14: Para esquerda ((para e olha para lousa))... para a direita. } \\
\text { A6: Para a direita porque não deu negativo. } \\
\text { A?: Deu positivo. } \\
\text { P: Onde está o negativo aqui ((aponta para a conta))? } \\
\text { A6: Não tem negativo... então... } \\
\text { P: Então ele vai para onde? } \\
\text { A6: Para a direita. } \\
\text { As: Para direita. } \\
\text { A6: Então eu falei para direita... porque ele não tem negativo. } \\
\text { A11: Para direita. } \\
\text { P: Gente... olha só como é importante aqui óh... a análise } \\
\text { matemática... PESSOAL... Olha só aqui óh... como é } \\
\text { importante a análise matemática disso aqui pra tu chegar } \\
\text { ((professor atende a porta para um aviso evento sobre o meio } \\
\text { ambiente - em torno de } 50 \text { segundos))... pessoal... vamos } \\
\text { discutir algumas coisas... preciso que vocês colaborem... se } \\
\text { todo mundo falar ao mesmo tempo... não vai dar... olha aqui } \\
\text { óh... o grupo vai para a direita ou vai para a esquerda? } \\
\text { As: Direita } \\
\text { P: Por quê? } \\
\text { As: Porque é positivo. } \\
\text { P: A velocidade é positiva... entenderam? Agora é assim } \\
\text { óh...Vamos pegar os } 3 \text { exemplos... } \\
\end{array}$} & Explicação \\
\hline & & Argumentação \\
\hline & & $\begin{array}{c}\text { Dedução } \\
\text { Justificativa }\end{array}$ \\
\hline
\end{tabular}




\section{Episódio 5 - Interpretação dos resultados matemáticos}

\begin{tabular}{|c|c|c|}
\hline $\begin{array}{l}\text { Tempo inicial } \\
\text { e final da cena }\end{array}$ & Transcrição, Descrição das ações e linguagens & Ciclo Argumentativo \\
\hline \multirow[t]{3}{*}{$\begin{array}{l}00: 35: 35 \\
00: 37: 00\end{array}$} & \multirow{3}{*}{$\begin{array}{l}\text { P: A primeira situação olha aqui óh... ((professor fala } \\
\text { enquanto desenha cada situação na lousa)). } \\
\text { A7: É o lado esquerdo que... } \\
\text { P: Era dez quilos e vinte quilos... a segunda era o } \\
\text { contrário...né? } \\
\text { A9: Era vinte e dez. } \\
\text { P: Vinte e dez... } \\
\text { A9: Depois é dez e vinte. } \\
\text { P: E a terceira situação aqui... } \\
\text { A?: Dez. } \\
\text { P: Dez e... vinte... } \\
\text { A9: Só que eles encontram. } \\
\text { P: Só que eles o que? } \\
\text { A9: Se encontram. } \\
\text { P: Certo? Olha aqui óh... qual é a velocidade aqui então? } \\
\text { ((referindo-se à velocidade do conjunto na primeira situação, } \\
\text { depois na segunda e na terceira situação)) três metros por } \\
\text { segundo... quatro metros por segundo... e aqui? } \\
\text { A9: Zero vírgula três três três três... ((professor anota o valor } \\
\text { na lousa)). } \\
\text { P: Esquece esse último aqui... vamos olhar esses aqui... } \\
\text { agora assim óh.... feita a análise matemática... feita a análise } \\
\text { matemática... gente... assim óh gente... o que vocês tem que } \\
\text { pensar em física? Será que minha conta está certa ou será } \\
\text { que minha conta está errada? Eu tenho que ter essa } \\
\text { abstração... a matemática pode me confirmar o resultado... } \\
\text { mas... se eu não sei o resultado... eu acho o resultado... eu } \\
\text { tenho que o que? Abstrair para ver se ele ver se ele... } \\
\text { condiz... com mais ou menos a teoria. }\end{array}$} & $\begin{array}{c}\text { Explicação } \\
\text { Cuidado com os dados } \\
\text { Definição das } \\
\text { variáveis relevantes ao } \\
\text { problema }\end{array}$ \\
\hline & & Argumentação \\
\hline & & $\begin{array}{l}\text { Seriação, classificação } \\
\text { e organização dos } \\
\text { dados } \\
\text { Justificativa }\end{array}$ \\
\hline $\begin{array}{l}\text { Tempo } \\
\text { inicial e final } \\
\text { da cena }\end{array}$ & Transcrição, Descrição das ações e linguagens & Ciclo Argumentativo \\
\hline \multirow[t]{3}{*}{$\begin{array}{c}00: 37: 00- \\
00: 37: 20\end{array}$} & \multirow{3}{*}{$\begin{array}{l}\text { P: Por que que esse aqui aumenta a velocidade final? } \\
\text { ((aponta para a segunda situação)). } \\
\text { A6: O que? } \\
\text { P: Por que que esse aqui aumenta a velocidade final? } \\
\text { ((aponta para a segunda situação)). } \\
\text { A6: Porque é a massa... massa } \\
\text { P: Mas o que que essa massa fez para aumentar a } \\
\text { velocidade? } \\
\text { A7: É a massa maior com a velocidade... } \\
\text { P: O que que ela aumenta? } \\
\text { A6: O peso. } \\
\text { P: Não. } \\
\text { A7: A transfe/... a transferência. } \\
\text { A11: (Supondo) que a massa seja cinco... isso aí. }\end{array}$} & Explicação \\
\hline & & Argumentação \\
\hline & & Justificativa \\
\hline $\begin{array}{l}\text { Tempo inicial } \\
\text { e final da cena }\end{array}$ & Transcrição, Descrição das ações e linguagens & Ciclo Argumentativo \\
\hline $\begin{array}{l}00: 37: 20 \\
00: 38: 10\end{array}$ & $\begin{array}{l}\text { P: Não... mas qual é a grandeza que ela... faz aumentar... a } \\
\text { massa? } \\
\text { A6: A velocidade? }\end{array}$ & Explicação \\
\hline
\end{tabular}




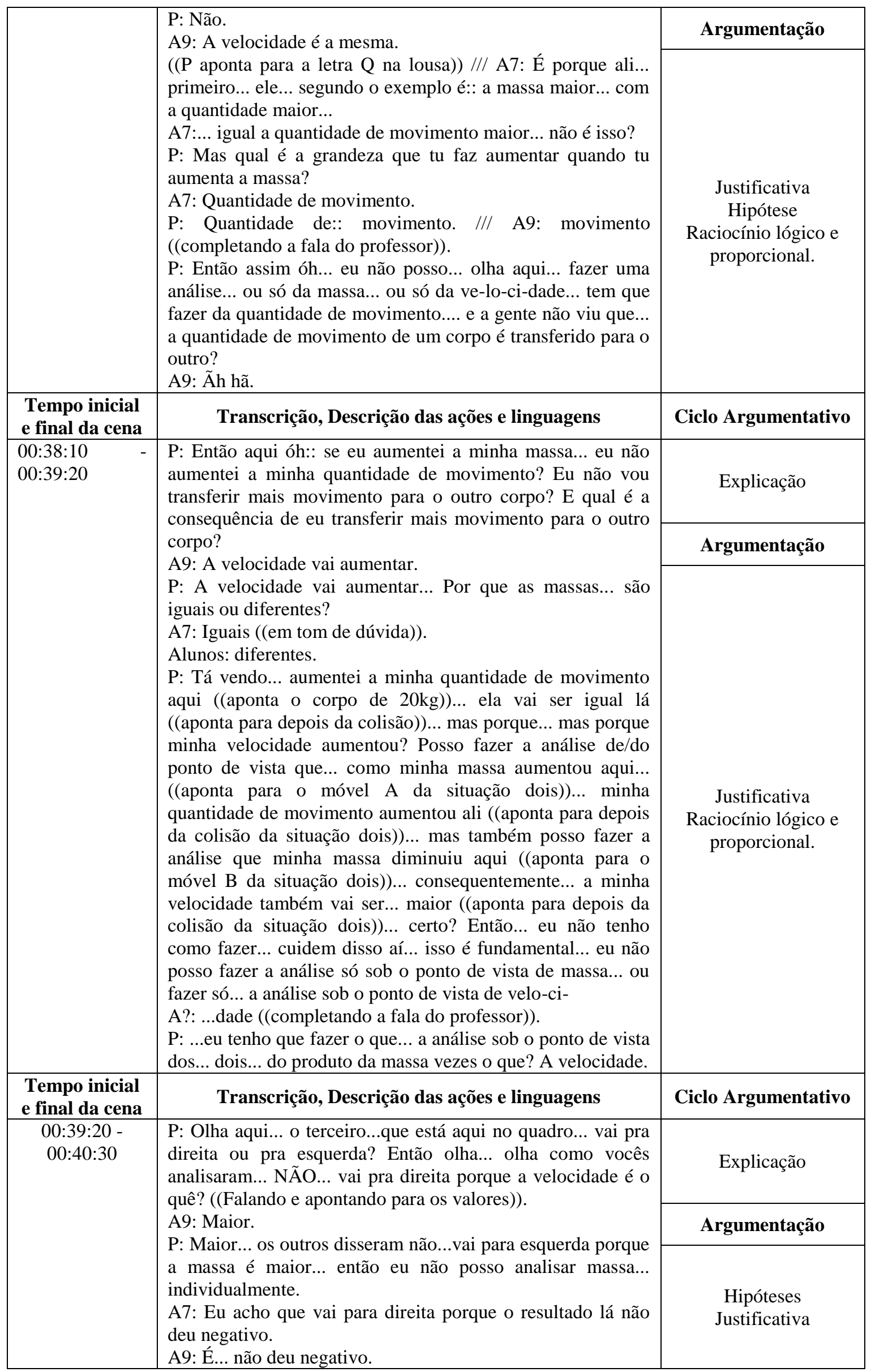




\begin{tabular}{|c|c|c|}
\hline & $\begin{array}{l}\text { P: Tudo bem... nós chegamos a esse resultado... a } \\
\text { matemática que explicou isso aí... só que eu tenho que } \\
\text { voltar... será que ta certo ou errado isso aqui? Entendeu? Não } \\
\text { adianta eu fazer uma conta lá e deixar... e pronto deu isso } \\
\text { aí... não... as vezes a conta pode estar errada... "não... mas eu } \\
\text { fiz tudo certinho" ((simulando a fala de um estudante))... } \\
\text { tudo bem... mas pode ser que o teu resultado lá não condiz } \\
\text { com o que... tu pensou... então tu tem que fazer a análise... } \\
\text { olha aqui... se tu analisar só com a velocidade... esse corpo } \\
\text { iria pra onde? Quem que é maior? Direita... se eu analisar só } \\
\text { pela massa o corpo iria para onde? } \\
\text { A9: Esquerda. } \\
\text { P: Então eu não posso analisar só pela... }\end{array}$ & \\
\hline $\begin{array}{l}\text { Tempo inicial } \\
\text { e final da cena }\end{array}$ & Transcrição, Descrição das ações e linguagens & Ciclo Argumentativo \\
\hline \multirow[t]{3}{*}{$\begin{array}{l}00: 40: 30 \\
00: 41: 20\end{array}$} & \multirow{3}{*}{$\begin{array}{l}\text { A7: Ele não vai se mexer então... } \\
\text { P ((interrompendo a aluna)): NÃ̃ meu anjo... o que eu estou } \\
\text { dizendo pra ti é que você não pode olhar... e analisar um } \\
\text { problema desse aí... só olhando massa ou só olhando } \\
\text { velocidade... eu tenho que analisar o que? Pela quantidade de } \\
\text { movimento... aí óh... que é o que? Massa vezes... } \\
\text { A7 e A8: A velocidade. } \\
\text { P: ISSO... ((risos pela turma)) isso aí gente é um erro } \\
\text { conceitual muito grande... eu queria que pelo menos vocês } \\
\text { tentassem... e que essa aula servisse disso aí... óh... para } \\
\text { mim... é:.... tentar mudar esse meu conceito... e não analisar } \\
\text { ou só massa ou só:: } \\
\text { A9: Velocidade. } \\
\text { P: E sim analisar a quantidade de:: } \\
\text { Alunos: Movimento. }\end{array}$} & Explicação \\
\hline & & Argumentação \\
\hline & & $\begin{array}{l}\text { Hipótese } \\
\text { Justificativa }\end{array}$ \\
\hline $\begin{array}{l}\text { Tempo inicial } \\
\text { e final da cena }\end{array}$ & Transcrição, Descrição das ações e linguagens & Ciclo Argumentativo \\
\hline \multirow[t]{3}{*}{$\begin{array}{c}00: 41: 20- \\
00: 43: 00\end{array}$} & \multirow{3}{*}{$\begin{array}{l}\text { P: O que é massa vezes velocidade... alguma pergunta? } \\
\text { Alguma dúvida? Tranquilo? } \\
\text { A7: Ô professor... por favor... } \\
\text { P: Pois não? } \\
\text { A7: É obrigado eles se mexerem? } \\
\text { P: Não. } \\
\text { A7: Eles não podem ficar paradinhos? } \\
\text { P: Claro que pode... olha aqui óh... se eu pegar... lembra que } \\
\text { eu fiz um exemplo para vocês lá...umas aulas atrás? Que eu } \\
\text { disse pra vocês que existem infinitas possibilidades? Isso } \\
\text { aqui tu pode começar hoje e ficar até fim de semana que vem } \\
\text { fazendo ((aponta para as resoluções na lousa))... vai tentando } \\
\text { as hipóteses e tu vai chegar num ponto que os corpos vão } \\
\text { ficar o quê? } \\
\text { Alunos: parados. } \\
\text { P: Parados ((choca os dois punhos, parando no meio do } \\
\text { caminho)). } \\
\text { P: Mas pra isso você tem que fazer o que? } \\
\text { A7: Hipóteses. } \\
\text { P: Hipóteses... ou então fazer uma atividade experimental... } \\
\text { né? } \\
\text { A9: Eu vou fazer isso... ((inaudível)). } \\
\text { P: Pega... pega dois carrinhos lá... óh... se tu pensar numa } \\
\text { coisa... essa quantidade de movimento tem que ser igual a } \\
\text { essa aqui ((aponta a colisão frontal exemplificada na } \\
\text { lousa))... então só pegar dois números que multiplicando da } \\
\text { igual a dois números que estão multiplicando... dez vezes } \\
\text { cinco... qual é o número que tu tem que botar aqui para }\end{array}$} & Explicação \\
\hline & & Argumentação \\
\hline & & $\begin{array}{c}\text { Hipótese } \\
\text { Justificativa }\end{array}$ \\
\hline
\end{tabular}




\begin{tabular}{|l|l|l|}
\hline multiplicar aqui $(($ aponta os corpos que colidem frontalmente \\
representados na lousa) $\ldots$ dois e meio vezes vinte? \\
Cinquenta... e aqui $(($ corpo da frente) $) \ldots$ \\
A9: Cinquenta. \\
P: Tá... Mas isso não vem ao caso... vai acontecer? Pode... se \\
eu pegar uma colisão... é... real... por mais que os carros \\
batam... eles nunca vão ficar parados... um vai arrastar... o \\
outro ((representa com as mãos as colisões))... não interessa \\
se for frontal ou se for o que... traseira.
\end{tabular}

\section{Episódio 6 - O problema aberto dos astronautas}

\begin{tabular}{|c|c|c|}
\hline $\begin{array}{c}\text { Tempo } \\
\text { inicial e final } \\
\text { da cena }\end{array}$ & \multicolumn{2}{|l|}{ Transcrição, Descrição das ações e linguagens } \\
\hline $\begin{array}{l}0: 43: 00 \\
00: 44: 10\end{array}$ & \multicolumn{2}{|c|}{$\begin{array}{l}\text { P: Não interessa.... muita brincadeira hoje ... beleza... gente... segunda atividade que eu } \\
\text { quero propor para vocês... certo... é assim ó... é vapt vupt... é } 5 \text { minutinhos para vocês } \\
\text { fazerem... vai rapidão... problema aberto... do astronauta aí... primeira coisa que eu } \\
\text { quero que identifique aí óh... se isso aí... é... um... choque inelástico ou não é... bom... } \\
\text { então aqui óh... rapidão... análise do problema... baixa a cabeça e faz/discuta com o } \\
\text { grupo... } \\
\text { A7: Aqui... em cinco? } \\
\text { P: Mas é rápido... } \\
\text { A7: Não é rápido. } \\
\text { P: É rápido... é só vocês se concentrarem que vocês fazem rapidinho... hipóteses... o } \\
\text { que vai usar para resolver... certo? Rapidão. }\end{array}$} \\
\hline $\begin{array}{c}\text { Tempo } \\
\text { inicial e final } \\
\text { da cena }\end{array}$ & Transcrição, Descrição das ações e linguagens & Ciclo Argumentativo \\
\hline \multirow[t]{3}{*}{$\begin{array}{l}00: 44: 10 \\
00: 44: 40\end{array}$} & \multirow{3}{*}{$\begin{array}{l}\text { A2: É... né? Claro que é... } \\
\text { A6: O quê? } \\
\text { A2: Não... } \\
\text { A6: Primeiro temos que colocar hipóteses óh... tipo aqui... } \\
\text { qual a velocidade dele para chegar lá?... Dois metros por } \\
\text { segundos... porque ele vai estar flutuando... } \\
\text { A2: É. } \\
\text { A6: ÔH PROFESSOR... ÔH PROFESSOR. } \\
\text { A2: Tem que... perguntar se tem que contar que ele está no } \\
\text { espaço. } \\
\text { A6: Não outra coisa. } \\
\text { A2: Mas é... }\end{array}$} & $\begin{array}{l}\text { Cuidado com os dados } \\
\text { Definição das } \\
\text { variáveis relevantes ao } \\
\text { problema }\end{array}$ \\
\hline & & Argumentação \\
\hline & & $\begin{array}{c}\text { Seriação } \\
\text { Classificação e } \\
\text { organização dos dados } \\
\text { Previsão } \\
\text { Justificativa }\end{array}$ \\
\hline $\begin{array}{c}\text { Tempo } \\
\text { inicial e final } \\
\text { da cena }\end{array}$ & Transcrição, Descrição das ações e linguagens & Ciclo Argumentativo \\
\hline $\begin{array}{l}00: 44: 40 \\
00: 46: 20\end{array}$ & $\begin{array}{l}\text { A6: O professor... o professor... daí tipo aqui... esse aqui vai } \\
\text { estar parado... esperando esse ou os dois vão... } \\
\text { P: Tu que vai hipotetizar... o que tu entendeu do desenho? } \\
\text { A6: Eu entendi que ele tem que agarrar o galão e ver qual que } \\
\text { é a velocidade que ele tem... então... } \\
\text { A2: Então... esse daqui está parado... esse está em... } \\
\text { A6: Não... não... vamos fazer assim... esse nós coloca cinco. } \\
\text { P: Quem que atirou pra quem? } \\
\text { A6: Hã? }\end{array}$ & $\begin{array}{l}\text { Cuidado com os dados } \\
\text { Definição das } \\
\text { variáveis relevantes ao } \\
\text { problema }\end{array}$ \\
\hline
\end{tabular}




\begin{tabular}{|c|c|c|}
\hline & \multirow[b]{2}{*}{$\begin{array}{l}\text { P: Quem que atirou pra quem? } \\
\text { A2: Esse jogou pra esse. } \\
\text { A6: Esse jogou pra esse. } \\
\text { A1: Do A para o B. } \\
\text { A6: Do A para o B. } \\
\text { A2: Então esse tava parado. } \\
\text { A6: Esse ta parado... o A. } \\
\text { A2: o (B) estava parado. } \\
\text { P: Eu acho que os dois estão parados... se tu ler o problema } \\
\text { bem. } \\
\text { A6: Encontram-se livre na parte externa da... então... se eles } \\
\text { estão parados e ele jogou... tem que/tem que... o máximo que } \\
\text { tem que calcular aqui é a distância. } \\
\text { P ((apontando para a folha de A6)): É só tu modelar. } \\
\text { A6: Ah... então vou colocar... aqui cinco. } \\
\text { A2: Pode usar o mesmo peso? } \\
\text { P: Oi? } \\
\text { A2: Pode usar o mesmo peso? } \\
\text { P: Tu vai hipotetizar... as tuas hipóteses tu que vai colocar. } \\
\text { A6: Não... vamos fazer assim então óh... vamos fazer assim } \\
\text { óh... aqui nós colocamos cinco e aqui dez. } \\
\text { A2: Então ta feito aqui cara... se for fazer que nem um desse } \\
\text { aqui ((aponta para o caderno)). } \\
\text { A6: Não... é para a gente fazer assim... não é pra nós copiar... } \\
\text { né oh:: ((desdenhando o colega)). } \\
\text { A2: Tipo... é modelo. } \\
\text { A6: Capaz. } \\
\text { A2: É modelo. } \\
\text { A6: Vamos fazer assim... esse aqui é de/... esse daqui é cinco e } \\
\text { esse é dez. }\end{array}$} & Argumentação \\
\hline & & $\begin{array}{c}\text { Seriação } \\
\text { Classificação e } \\
\text { organização dos dados } \\
\text { Justificativa }\end{array}$ \\
\hline $\begin{array}{c}\text { Tempo } \\
\text { inicial e final } \\
\text { da cena }\end{array}$ & Transcrição, Descrição das ações e linguagens & Ciclo Argumentativo \\
\hline \multirow[t]{3}{*}{$\begin{array}{c}00: 46: 20- \\
00: 47: 00\end{array}$} & \multirow{3}{*}{$\begin{array}{l}\text { A2: Por quê cinco e dez? } \\
\text { A6: Porque sim. } \\
\text { A2: Mas porque esse é dez? } \\
\text { A6: Hã? A VELOCIDADE. } \\
\text { A2: Tá... mais por que? } \\
\text { A1: Mas os dois não vão estar na mesma velocidade? } \\
\text { A2: Mas por que que um é maior que outro? } \\
\text { A6: A VELOCIDADE DO GALÃO... ELES NÃO ESTÃO... } \\
\text { eles jogam um galão pro outro. } \\
\text { A2: Cinco metros por segundo... né? } \\
\text { A6: É... daí a gente copia tudo isso aqui e troca o cinco pelo } \\
\text { zero ((se referindo ao problema modelo)). } \\
\text { A6: Não vai fazer A3? A3 não vai fazer? } \\
\text { A2: A cara esquece... } \\
\text { A6: Ah... (fica falando para a parede). } \\
\text { A1: Tá... Como é que deu... deu agora? }\end{array}$} & $\begin{array}{l}\text { Cuidado com os dados } \\
\text { Definição das } \\
\text { variáveis relevantes ao } \\
\text { problema }\end{array}$ \\
\hline & & Argumentação \\
\hline & & $\begin{array}{c}\text { Seriação } \\
\text { Classificação e } \\
\text { organização dos dados } \\
\text { Dedução }\end{array}$ \\
\hline $\begin{array}{c}\text { Tempo } \\
\text { inicial e final } \\
\text { da cena }\end{array}$ & Transcrição, Descrição das ações e linguagens & Ciclo Argumentativo \\
\hline \multirow[t]{3}{*}{$\begin{array}{l}00: 47: 00 \\
00: 48: 00\end{array}$} & \multirow{3}{*}{$\begin{array}{l}\text { A2: Mas o peso é... vamos fazer peso dez também... né? Dez e } \\
\text { vinte... né? Hã? } \\
\text { A2: Vamos fazer o peso o mesmo. } \\
\text { A6: Como assim? } \\
\text { A2: O peso cara... o peso. } \\
\text { A6: Não, claro que não. } \\
\text { A2: Então vai ter que mudar o peso também. } \\
\text { A6: Se é cinco e se é dez... é quinze ((referindo-se à soma)). }\end{array}$} & $\begin{array}{l}\text { Cuidado com os dados } \\
\text { Definição das } \\
\text { variáveis relevantes ao } \\
\text { problema }\end{array}$ \\
\hline & & Argumentação \\
\hline & & $\begin{array}{c}\text { Seriação } \\
\text { Classificação e }\end{array}$ \\
\hline
\end{tabular}




\begin{tabular}{|c|c|c|}
\hline & $\begin{array}{l}\text { A2: Ô animal... olha aqui cara... olha aqui óh...o peso... óh } \\
\text { ((apontando para a sua folha)). } \\
\text { A6: Hei... Mas olha só... mas olha só ((apontando para a folha } \\
\text { do colega))... aqui é vinte e aqui é dez... dez e vinte... trinta e } \\
\text { aqui é cinco e dez... é quinze. } \\
\text { A2: Não cara olha aqui... esse aqui é a velocidade... } \\
\text { ((apontando para a folha do colega)) eu to falando do peso. } \\
\text { A1: Tem que trocar o peso. } \\
\text { A2: O peso óh... } \\
\text { A6: AH ((expressão de que compreendeu)). } \\
\text { A2: Peso... peso peso... velocidade velocidade... aqui óh... } \\
\text { velocidade velocidade ((apontando na folha de A6))... tem que } \\
\text { ver o peso deles... } \\
\text { A2: ....por isso que eu estou perguntando... eu já arrumei.. dez } \\
\text { e vinte. } \\
\text { A6: Pode ser.... vamos fazer assim então... vamos fazer na } \\
\text { folha. } \\
\text { A2: Da uma folha aí... Vou fazer em forma de bola. }\end{array}$ & $\begin{array}{c}\text { organização dos dados } \\
\text { Justificativa } \\
\text { Dedução }\end{array}$ \\
\hline $\begin{array}{l}\text { Tempo } \\
\text { inicial e final } \\
\text { da cena } \\
\end{array}$ & Transcrição, Descrição das ações e linguagens & Ciclo Argumentativo \\
\hline \multirow[t]{3}{*}{$\begin{array}{l}00: 48: 00 \\
00: 49: 05\end{array}$} & \multirow{3}{*}{$\begin{array}{l}\text { A6: Tu vai fazer? } \\
\text { A2: Fica melhor daí... e essa outra bola vai estar indo para } \\
\text { onde? } \\
\text { A2: Para lá também? } \\
\text { A6: Fala logo guria... o que ela tá pedindo... ((sobre conversa } \\
\text { paralela de A3 e A4 sobre assuntos pessoais)). } \\
\text { A3: Curioso... né? } \\
\text { A2: Quilogramas ou quilo só? } \\
\text { A6: Quilogramas... Dez quilogramas ((fala e escreve)). } \\
\text { A2: E essa daí vai estar indo para lá e a outra também... né? } \\
\text { A2: As duas pra lá. } \\
\text { A6: Vai ficar assim e assim... né? } \\
\text { A2: Eu acho que não... se ele jogou pra esse... e esse vai } \\
\text { pegar ((faz gestos da situação))... /I/ A1 ((olhando para a } \\
\text { folha do A6)): Não vai para o outro lado. } \\
\text { A6: Não... as duas para lá? Então essa aqui vai ficar assim? } \\
\text { Isso? } \\
\text { A2: É } \\
\text { A1: É... os dois para o mesmo lado... Ta... o segundo é vinte? } \\
\text { A6: Tá... daí aqui no caso... a outra/a terceira bolinha. } \\
\text { A2: Que é junto. } \\
\text { A6: Que é junto... quinze. } \\
\text { A2: Tu fez o mesmo valor. } \\
\text { ((De 00:49:05 a 00:52:30 os alunos escrevem no caderno e } \\
\text { fazem conversas paralelas à atividade)) }\end{array}$} & $\begin{array}{l}\text { Cuidado com os dados } \\
\text { Definição das } \\
\text { variáveis relevantes ao } \\
\text { problema }\end{array}$ \\
\hline & & Argumentação \\
\hline & & $\begin{array}{c}\text { Seriação } \\
\text { Classificação e } \\
\text { organização dos dados } \\
\text { Hipóteses }\end{array}$ \\
\hline $\begin{array}{c}\text { Tempo } \\
\text { inicial e final } \\
\text { da cena }\end{array}$ & Transcrição, Descrição das ações e linguagens & Ciclo Argumentativo \\
\hline \multirow[t]{3}{*}{$\begin{array}{c}00: 52: 30- \\
00: 53: 40\end{array}$} & \multirow{3}{*}{$\begin{array}{l}\text { A2: Vai dar três metros por segundo cara... } \\
\text { A6: O professor apagou o quadro ((incomodado)). } \\
\text { A2: Tem aqui óh }((\text { aponta para a própria folha))... a primeira } \\
\text { inteirinha... vai dá... se copiar... ta com os mesmos números... } \\
\text { olha aqui óh ((aponta para a folha de A6))... tá com o mesmo } \\
\text { peso e a mesma velocidade... olha... vai dar:: treze/... vai dar } \\
\text { três segun:: três metros por segundo. } \\
\text { A1: Dá a mesma resposta que o primeiro? } \\
\text { A2: É... mesma conta. } \\
\text { A1: Traduzindo... tu pegou e... botou a primeira na um. } \\
\text { A2 ((afirmando com a cabeça)): Mais ou menos... eu não né? }\end{array}$} & $\begin{array}{c}\text { Explicação } \\
\text { Definição das } \\
\text { variáveis relevantes ao } \\
\text { problema }\end{array}$ \\
\hline & & Argumentação \\
\hline & & $\begin{array}{c}\text { Classificação e } \\
\text { organização dos dados } \\
\text { Justificativa } \\
\text { Dedução }\end{array}$ \\
\hline
\end{tabular}




\begin{tabular}{|l|l|l|}
\hline & é nós... & \\
A1: É. & A2: Que botamos o mesmo peso e o mesmo valor. & \\
A6: Tá... daí aqui nós vamos fazer. & \\
A2: Vai dar a mesma coisa cara. & \\
A6: Tá... calma aí... calma aí... aqui é vinte... se aqui é vinte... & \\
vinte vezes cinco... vai ficar dez vezes cinco... qual é o peso & \\
normal? Qual foi o peso que nós colocamos? cinco... cinco & \\
metros por segundo. & \\
\hline
\end{tabular}

$<00: 53: 54>$ A2: Ó, dá $2 \mathrm{~m} / \mathrm{s}$. b), $3 \mathrm{~m} / \mathrm{s}$.

$<00: 54: 33>$ A6: 20 vezes 10 ?

$<00: 54: 34>$ A2: Por que 20 vezes 10 ?

$<00: 54: 35>$ A6: Quanto é?

$<00: 54: 43>$ A2: Vai dar 20 (vinte). Dá 200 (duzentos), não dá?

$<00: 54: 50>$ A6: É.

$<00: 54: 54>$ A2: Mas por que, cara?

$<00: 54: 55>$ A6: Relaxa.

$<00: 54: 57>$ A2: Depois quero ver. Já venho.

$<00: 56: 15>$ P: Pessoal, vamos?

$<00: 56: 16>$ A6: Calma aí, professor, não!

$<00: 56: 19>$ P: Vamos lá.

<00:56:21> A6: Ah, professor, não vai adiantar nada, calma aí.

(conversa paralela)

<01:00:47> P (falando com A6): Qual velocidade que o móvel tem, antes? E com qual velocidade eu to voltando? Ó, elaboração de estratégia, aí sim, isso aí vai ser tua aplicação da estratégia (apontando a folha de A6).

$<01: 01: 04>$ A6: Olha, eu cansei disso aí, faz aquela bagaça que estava no quadro.

$<01: 01: 33>$ A2: Tá errado?

<01:01:37> A6: Não, faz aquilo lá agora (apontando para o quadro). Não, é isso aí, só que tem que fazer a conta.

$<01: 01: 57>$ A2: Ah, não sei fazer aquilo lá.

$<01: 02: 45>$ A6: Faz esse bagulho ali.

$<01: 02: 47>$ A2: Não sei.

$<01: 03: 23>$ P: Pessoal! Assim, ó, a gente ta evoluindo, isso é um bom sinal. (inaudível - áudio do professor atrapalhado pela conversa paralela do grupo). Que é um trabalho que vocês não estavam acostumados a fazer, ta? Uma proposta de trabalhar assim, vamos discutir bem rapidinho isso aqui, que a gente já ta quase na segunda aula, depois você pode terminar em casa na próxima aula daí traz, sugestão: esse material eu preciso de uma cópia, que é do trabalho de pesquisa do professor, então eu gostaria que se vocês pudessem me entregar, pode tirar Xerox, gente, assim ó, vamos fazer as coisas bem simples para depois a gente subir mais. Então assim, quando eu peço pra fazer uma análise do problema, é simples o que eu quero agora, não quero que faça uma redação dissertativa sobre o problema, eu quero simplesmente que escreva, ó, olha como eu faria isso aí: eu preciso achar a velocidade final do conjunto tanque mais astronauta $\mathrm{B}$, pronto, essa é minha análise do problema, certo? Se tu quiser daí ó, para isso vou usar a lei da conservação da quantidade de movimento, e vai escrevendo, é simplesmente montar uma frase, simples, certo? É o suficiente. Olha só aqui, as minhas hipóteses, gente, como eu poderia fazer essas decisões, olha aqui, o que precisa para usar a lei da conservação da quantidade de movimento? Precisa do que?

$<01: 06: 16>$ A: Massa e velocidade.

$<01: 06: 21>$ P: Pessoal, eu vou vir aqui (apontando o quadro), eu precisaria botar a massa do astronauta A, massa do astronauta B e a massa do que? Do tanque. Mas eu 
posso botar qualquer valor? Pode, o valor que eu quiser, é óbvio que tu não vai botar valores absurdos, a massa do astronauta não vai ser $1 \mathrm{~kg}$, né? $\mathrm{O}$ que mais eu preciso colocar nas minhas hipóteses?

<01:07:01> A: A velocidade. A velocidade do astronauta A, do astronauta B e do tanque.

<01:07:10> A7: Professor, a gente fez o astronauta B e o tanque como uma coisa só. Tipo assim...

<01:07:19> P: Não, não está errado.

$<01: 07: 23>$ A7: Porque ele está segurando...

$<01: 07: 25>$ P: Mas a questão é a seguinte, olha só, o ideal seria tu colocar separado porque vamos supor que se eu pedisse para você comparar esse valor, qual é a massa que você colocou?

$<01: 07: 39>$ A7: 10

$<01: 07: 42>$ P: 10. Se tu botar 20, altera alguma coisa? Entende? Tu ia jogar esses valores aqui, agora aqui, ó, eu quero chamar a atenção de vocês para o seguinte: se os dois estão paradinhos no espaço, mas como eu sei que estão paradinhos? Lá não tem super-homem nem nada, né? Então se eles estão lá, estão livres, não tem nenhuma força, eles estão o que?

$<01: 08: 13>$ A: Parados

$<01: 08: 14>$ P: Então qual é a velocidade deles?

$<01: 08: 15>$ A: Zero.

<01:08:18> P: Ah, mas eu botei que a velocidade do astronauta era 10, não tem problema nenhum, só que vai modificar o seu resultado. Isso aqui, essa hipótese, nome bonito que a gente gosta de falar são condições iniciais, condições de contorno, ou seja, eu vou modelar o meu problema para eu jogar os dados dentro do meu algoritmo, certo? $\mathrm{O}$ que mais que tu tem que colocar nessa hipótese aqui? Essa hipótese, tu tem que colocar pra tu chegar na solução, que isso aqui com certeza é um choque inelástico, alguém colocou que é outro tipo de choque? Alguém colocou mais alguma coisa na hipótese? Nada?

$<01: 09: 28>$ A7: A gente só, tipo, a gente só não fez o desenho...

$<01: 09: 40>$ P: Não, a maneira que tu organiza aqui é tua maneira, gente, tu tem que elaborar uma estratégia, o que é elaborar uma estratégia? Eu quero saber como eu vou resolver isso aqui.

$<01: 10: 01>$ A7: Usando a quantidade de movimento...

<01:10:03> P: Ó, conservação de quantidade de movimento, ou seja, a quantidade de movimento antes tem que ser igual a quantidade de movimento depois. Quarto passo o que era? O que é o quarto passo aí? É eu aplicar a estratégia, por favor, Elis, venha para o quadro fazer a estratégia que vocês aplicaram aí. Então eu vou fazer o seguinte aqui, eu vou chamar o grupo da Elis, o grupo das meninas, ou alguém quer vir lá.

(discussão sobre quem vai ao quadro)

$<01: 11: 25>\mathrm{P}$ : Eu só quero que faça o passo 4.

(alunos comentam sobre o barulho do giz e conversam aleatoriamente).

<01:14:13> P: Pessoal, seguinte, não vai dar tempo, vamos, eu vou, como não vai dar tempo, na próxima aula a gente retoma para terminar isso aí. Eu quero discutir isso aí, na próxima aula a gente retorna. 